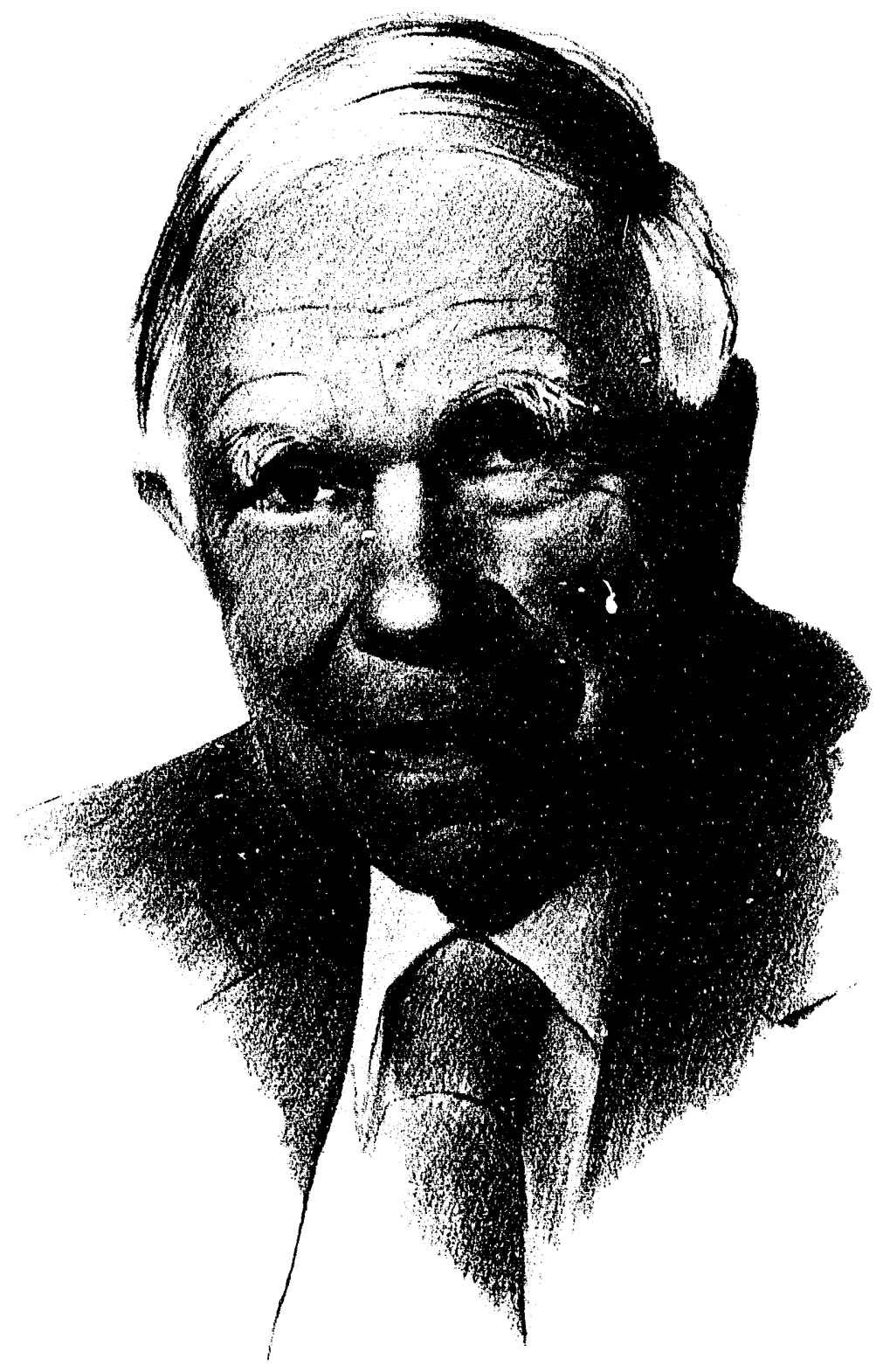


Artist's sketch of Glenn T. Seaborg

80th birthday celebration at Lawrence Berkeley Laboratory

Artwork by Flavio Robles, Jr. 
In recent years I have often augmented my scientific talks and general lectures to students with a brief description of my national service under the past ten presidents of the United States. I usually show slides, and share a few reminiscerces of particular meetings with the presidents, and how these contacts reflected the differences between the presidents in individual character and style of administration. This has proved to be immensely popular, and many people have urged me to record these experiences in written form.

In doing so now, I rely heavily on my daily journal, which I first began keeping as a boy of 14 (during the administration of Calvin Coolidge!), and which I continue to keep in a meticulous manner. You will note many detailed entries drawn directly from these journals, which are in the process of being printed in a report form by the Lawrence Berkeley Laboratory, and which will total close to 80 volumes, averaging nearly 600 pages each. A complete set of these will be available in the Library of Congress. Already deposited there (in 1992) are 57 volumes covering the years 1927-1975. (The entire collection to be deposited there will total more than one million items, including correspondence, administrative files, drafts of publications, photographs, audiotapes, videotapes, films, minutes of meetings, hand-written notebooks, etc.)

Beginning with Franklin Delano Roosevelt, I have served, in one capacity or another, the last ten presidents. I knew each president (with the exception of Roosevelt) personally, most on a first-name basis. My wife Helen met eight of these presidents (all except Roosevelt and Truman). I have also known each of the last twelve vice presidents, beginning with Henry Wallace (who served during the third presidential term of Roosevelt), and all ten of the first ladies, including Eleanor Roosevelt. Helen also met the last eight First Ladies and most of the vice presidents. (I might add that I have met Herbert Hoover, Roosevelt's preciecessor, on a number of occasions during the years following his presidency.)

It has been very exciting to play some role in the making of national policy under different administrations, and to have the opportunity to learn something of how priorities are established and goals accomplished in the national government. I believe my visits to some 60 countries have also made some contributions to the improvement of international relations of our country. I consider myself privileged to have had the opportunity to become acquainted with these men, who have so much shaped history--most of whom I am pleased to say I also liked as individuals. I hope that the reader will enjoy this "cruise down memory lane," with its many firsthand accounts of things as they happened, drawn from my journal. 


\section{Franklin Delano Roosevelt}

My indirect contacts with President Franklin D. Roosevelt began in connection with my work on the Manhattan Project during World War II.

The discovery of fission by the two German chemists, Otto Hahn and Fritz Strassmann, in December, 1938, soon led to the recognition that uranium might be developed as the explosive ingredient for a bomb of unprecedented explosive capacity. The Hungarian-born American physicist Leo Szilard became very concerned about this possibility and believed that he should give some direct advice to the president in order to get the United States started on such a project. With the help of Albert Einstein, Szilard's recommendation reached Roosevelt and resulted in the immediate appointment of an Advisory Committee on Uranium (chaired by Lyman J. Briggs, Director of the Bureau of Standards) to investigate the problem.

In June, 1941, Roosevelt established, by executive order, the Office of Scientific Research and Development (OSRD), with Vannevar Bush as director, in order to better coordinate the scientific activities for the war. The OSRD was located within the Office for Emergency Management of the Executive Office of the President. The OSRD oversaw the atomic bomb development and the National Defense Research Committee (NDRC), under the chairmanship of James B. Conant. The Committee on Uranium became the OSRD's Section on Uranium, soon designated cryptically as the S-1 Section.

By the end of the summer of 1941, Bush, initially somewhat skeptical, became convinced that the possibility of producing an atomic bornb before the end of the war was so strong that every effort must be made as fast as possible. On October 9, 1941, he met with President Roosevelt and Vice President Henry Wallace to seek authority to proceed at a greatly increased level of intensity with commitments to spend millions of dollars, an increase in orders of magnitude. The president, in an historic decision, agreed both immediately and completely. From this point on, the effort proceeded at an accelerated rate.

One approach was to produce enriched uranium-235 (the fissionable isotope of uranium). The other approach was to produce 94239 , the fissionable isotope of the newly-discovered synthetic element with the atomic number 94-this element and its fissionable isotope had been discovered in early 1941, by my co-workers and me at the University of California, Berkeley (and was soon given the name "plutonium"). Quoting from my journal for Saturday, December 20, 1941:

"Arthur Compton wrote a memorandum (addressed to Vannevar Bush, James B. Conant, and Lyman J. Briggs) outlining a theoretical and experimental program to be centered at the University of Chicago and carried on with the cooperation of the groups at Columbia, Princeton, and Berkeley for the production of 94239 , for use in a nuclear explosive, through the operation of a nuclear chain reaction with natural uranium. Spurred on by Pearl Harbor, he suggested a speeded-up time schedule for obtaining knowledge of the conditions for a chain reaction by June 1,1942, 
production of a chain reaction by October 1,1942, a pilot plant for use of the chain reaction to produce 94 by October 1,1943, and the production of usable quantities of 94 by December 31, 1944."

Arthur Compton, director of what became known as the Metallurgical Laboratory at the University of Chicago, asked me to join him there and to take charge of the development of the chemical process for the separation of the plutonium to be produced in the chain reaction. I arrived in Chicago on April 19, 1942 (my thirtieth birthday).

It became apparent that more supervisory strength for the atomic bomb project was needed. After some attempts at arrangements that I will not attempt to describe here, the Army was placed in charge. On September 23, 1942, newlypromoted General Leslie R. Groves, chosen by General Brehon B. Somervell and General Whilhelm D. Styer, was assigned to run the project as part of the Manhattan Engineer District (established on August 13) which became known as the Manhattan Project. Lieutenant Colonel Kenneth B. Nichols became his chief aide. Bush and Conant and members of the S-1 Executive Committee continued in positions of responsibility.

On June 29, 1943, President Franklin Roosevelt wrote the following letter to General Groves, which was read to the menubers of our laboratory:

"My dear General Groves:

I have recently reviewed with Dr. Bush the highly important and secret program of research, development and manufacture with which you are familiar. I was very glad to hear of the excellent work which is being done in a number of places in this country under your immediate supervision and the general direction of the Committee of which Dr. Bush is Chairman. The successful solution of the problem is of the utmost importance to the national safety, and I am confident that the work will be completed in as short a time as possible as the result of the wholehearted cooperation of all concerned.

I am writing to you as the one who has charge of all the development and manufacturing aspects of this work. I know that there. are several groups of scientists working under your direction on various phases of the program. The fact that the outcome of their labors is of such great significance to the nation requires that this project be even more drastically guarded than other highly secret war developments. As you know, I have therefore given directions that every precaution be taken to insure the safety of your project. I am sure the scientists are fully aware of the reasons why their endeavors must be circumscribed by very special restrictions. Nevertheless, I wish you would express to them my appreciation of their willingness to undertake the tasks which lie before them in spite of the possible dangers and personal sacrifice involved. In particular, I should be glad to have you communicate the contents of this letter to the leaders of each important group. I am sure we can rely on the continued wholehearted and unselfish labors of those now engaged. Whatever the enemy may be planning, American Science will be equal to 
the challenge. With this thought in mind, I send this note of confidence and appreciation.

Very sincerely yours,

Franklin D. Roosevelt"

Much of the early incentive for proceeding with the atomic bomb project came from the United Kingdom. As a result, President Roosevelt included discussions of this project in early meetings with U.K. Prime Minister Winston Churchill and Canadian leaders. This cooperation diminished during the later days of the war.

As the project progressed, and in view of the potential applications of plutonium as a source of energy for peacetime applications, Vannevar Bush approached the discoverers of plutonium and its fissionable isotope (Joseph $\mathrm{W}$. Kennedy, Arthur C. Wahl, Emilio Segrè, and me) vith respect to the assignment of our patent rights to the government (our basic discoveries had been made in the course of our academic research conducted before we had any government contracts). Thus, as recorded in my journal, Kennedy and I met with Vannevar Bush on April 20, 1944:

"Kennedy and I arrived in Washington in the morning and at 10 a.m. went to Captain Lavender's office on the second floor of the Carnegie Foundation Building at 1530 P Street. He took us to see Vannevar Bush in the same building, who spoke to us about President Roosevelt having directed him to obtain all controlling patents in these matters to facilitate international dealings. Bush emphasized they have no intention of coercing us; however, he said, since the University of California is becoming so demanding, he is forced to be legal and tough with U.C."

Also on January 8, 1945, Bush wrote us as follows:

"I have discussed with Captain Lavender the purchase by the Government of rights under certain chemical discoveries that have been the subject of negotiations and I have [preliminarily] considered the details of the discoveries in their relation to the work undertaken by the University of California under contracts, and also as to the parts of the discoveries that were made before the contracts were in existence as well as during the periods of the contracts.

It appears to me that the extent of the rights to which you are entitled and the rights to which the Gover:iment is entitled are so interwoven that it is very difficult to separate them. As you know a heavy responsibility is placed upon Government officials in authorizing the expenditure of Gonernment funds of the amount that you have mentioned and I feel that the extent of the rights to discoveries made before the contracts and during the contracts periods should really be determined by formal Patent Office proceedings. 
You, of course, will appreciate the filing of a single application for patents to cover all of the involved subject matter, arising both before and during the contract periods, would secure a much firmer patent position than would result from filing applications piecemeal by you and the Government.

For this reason I have approved in general the proposal made by Captain Lavender to you that a single application be prepared covering all the work done on this particular subject with the understanding, to be confirmed in writing, that the title to the application covering the entire subject will be in you, subject to a non-exclusive license $i_{i}$ favor of the Government for all Government purposes.

It is not my desire to influence your decision in this matter as I feel that you should have a free hand in disposing of any rights to your discoveries made before any Government contracts. However, I do wish to express my opinion that both you and the Government would benefit through mutual cooperation in the filing and prosecution of a single application."

The complicated relations between the discoverers (inventors), the U.S. government, and the University of California tnok years to iron out, and a satisfactory settlement was not reached until May, 1955.

It is beyond the scope of the present account to describe the successful production of uranium-235 and plutonium-239 during the war; the successful test of a plutonium bomb at Alamogordo, New Mexico, on July 16, 1945 (known as Trinity); and the use of $235 \mathrm{U}$ and $239 \mathrm{Pu}$ as the explosive ingredients in bombs for detonation over Hiroshima (235U) and Nagasaki (239Pu), which led to the termination of the war. I was pleased that President Richard Nixon accepted my recommendation to present (on February 27, 1970) special Atomic Pioneer Awards to General Leslie Groves, Vannevar Bush, and James Conant (as described later in Section 6.)

Although I never met Franklin Roosevelt, I did have the opportunity to see him on the occasion of his presidential campaign visit to Chicago on October 28, 1944:

"Helen worked at the Met Lab in the afternoon. We had Steve Lawroski over for dinner and then the three of us went to Soldier Field (which was packed full) where we saw President Franklin D. Roosevelt ride around the field in an open car and heard him make a campaign speech." (Figure 1.) 


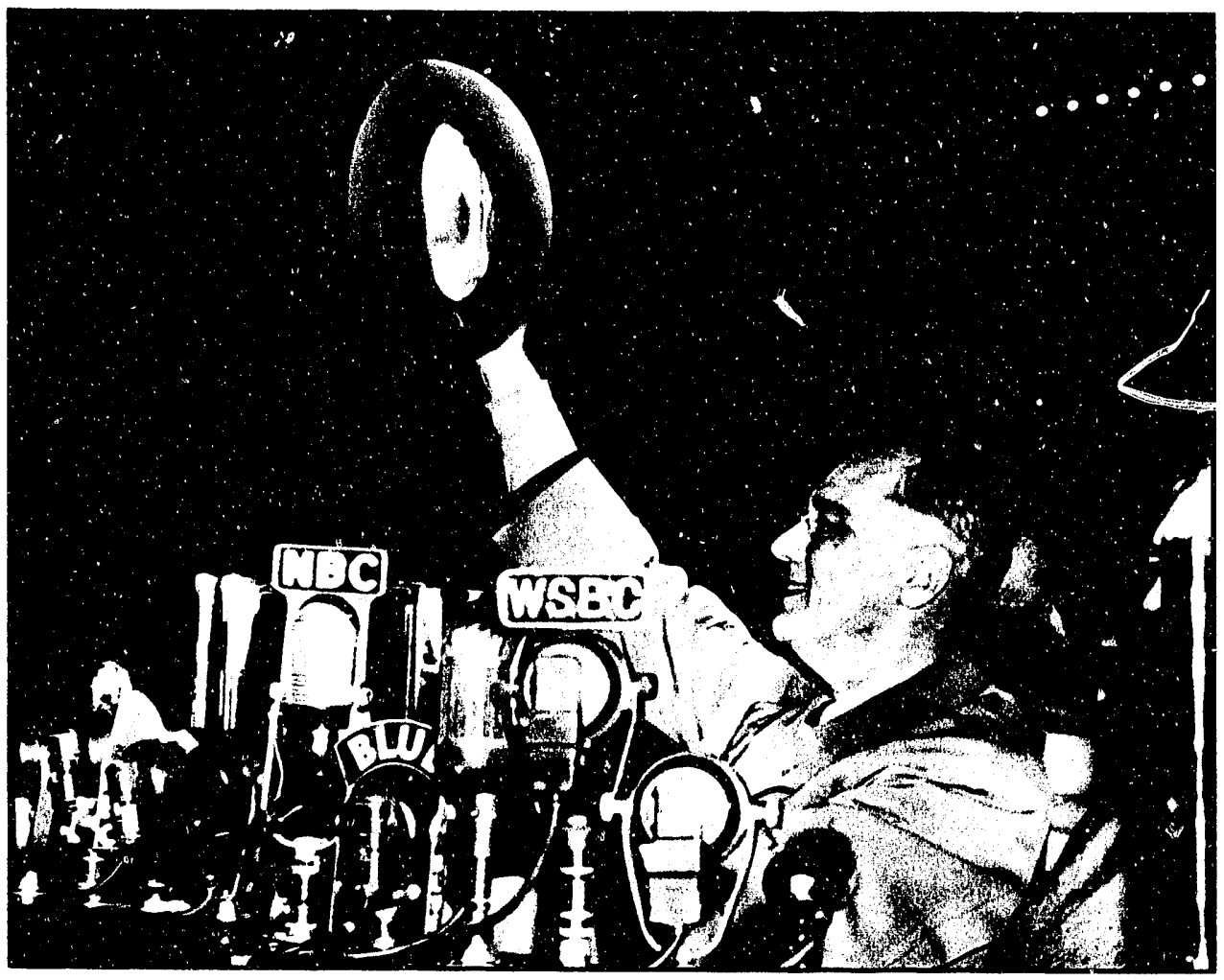

Figure 1. President Franklin D. Roosevelt giving campaign speech at Soldier Field, Chicago, October 28, 1944.

And then on April 12, 1945:

"President Roosevelt died at Hot Springs, Georgia, at 3:35 this afternoon. I first learned of this tragic event from Howard Lange who came by to tell me after hearing the news on his radio. All of our people are in a state of shock. The major radio stations turned their attention to this news for the remainder of the afternoon and throughout the evening. President Harry S Truman was sworn into office about six o'clock (EST) this evening."

I first met Henry A. Wallace who served as Vice President of the United States during the third presidential term (the war years 1941-1945) of Franklin Roosevelt at a conference on atomic energy arranged by University of Chicago Chancellor Robert M. Hutchins. Following is an abridged extract from my journal of Wednesday, September 19, 1945:

At 2:30 p.m. in Room 302 of the Social Science Building I attended the opening session of a three-day conference on Atomic Energy Control, held under the auspices of the University of Chicago. There were 46 invited official participants in the Conference: Chester I. Barnard, President, New Jersey Bell Telephone Company; Walter Bartky, Professor of Applied Mathematics, Acting Dean of Physical Sciences Division, University of Chicago;...E.C. Colwell, President, University of Chicago; E.U. Condon, Associate Director, Westinghouse Research Laboratory, 
East Pittsburgh, Pennsylvania;...Farrington Daniels, Professor of Physical Chemistry, University of Wisconsin and Director of Metallurgical Laboratory, University of Chicago; Karl K. Darrow, Bell Telephone Laboratories, New York;... James Franck, Professor of Physical Chemistry, Univer sity' of Chicago;... Reuben Gustavson, Vice-President and Dean of the Faculties, University of Chicago;... Selig Hecht, Professor of Biophysics, Columbia University;...Thorfin R. Hogness, Professor of Chemistry, University of Chicago; Robert M. Hutchins, Chancellor, University of Chicago; Irving C. Langmuir, Research Laboratory, General Electric Company;...David Lilienthal, Director, Tennessee Valley Authority;... Reinhold Niebuhr, Professor of Applied Christianity, Union Theological Seminary, New York; James J. Nickson, M.D., Metallurgical Laboratory, University of Chicago; Robert Redfield, Professor of Anthropology, Dean of Social Science Division, University of Chicago;...Beardsley Ruml, R.H. Macy and Company, Chairman Federal Reserve Bank of New York;...Eugene Staley, Institute of Pacific Relations, San Francisco; Joyce Stearns, Dean of Faculties, Washington University, former Director Metallurgical Laboratory, University of Chicago; Leo Szilard, Metallurgical Laboratory, University of Chicago; Oswald Veblen, Professor of Mathematics, institute of Advanced Study, Princeton, New Jersey;...Henry Wallace, Secretary, U.S. Department of Commerce, Washington, D.C.;...Harold Urey, Professor of Physical Chemistry, University of Chicago; E. . Wigner, Professor of Physics, Institute for Advanced Study, Princeton, New Jersey.

The scheduled program for the next three days is the following:

I. The Atomic Bomb: General Evaluation

II. Consequences of the Atomic Bomb Under Conditions of National Sovereignty
A. Influences on Military Strategy and International Relations
B. Economic Aspects

III. International Control
A. Control Through Existing International Organizations
B. Control by Mutual Inspections
C. Techniques of Moving Toward World Government

IV. If International Control is Unachievable: The Alternatives
A. Dispersal of Cities
B. Secrecy in Science

V. Individual Statements on Policy" 
Then on Saturday, September 22, 1945:

"I had lunch with Henry Wallace, Secretary of Commerce, and others who attended the Conference."

Henry Wallace (Figure 2..) seemed somewhat bitter as a result of being displaced ty Harry Truman as the vice-presidential candidate on Roosevelt's fourth-term campaign ticket. Had Wallace remained as vice president, he would have ascended to the office of the President of the United States.

Many years later, I met Eleanor Roosevelt during a visit to the World's Fair at Brussels in September, 1958. (Figure 3.)

Franklin Roosevelt obviously had a great appreciation for, and I believe a good understanding of, the work of his scientists and engineers on the Manhattan Project. I was one of his ardent admirers ever since he campaigned for the presidency in 1932.

\section{Harry $\mathbf{S}$ Truman}

Helen and I first encountered Harry Truman on July 21, 1944, while we were living in Chicago. We were listening on the radio to the Democratic National Convention; then, on the spur of the moment, we decided to go by streetcar from our apartment on the south side of Chicago, to the not so distant Convention Hall at the Coliseum, also located on the south side of Chicago. We simply walked into the unguarded Convention Hall, where we saw Harry Truman make his acceptance speech for the vice-presidential nomination. (Figure 4.) We found a place where we stood quite close to Truman as he gave his speech.

The affection that Harry Truman had for his wife Bess and the degree he depended on her for support in his arduous duties are so well known that it has become legendary. (Figure 5.)

My first contact with Harry Truman (after he became president) came in December, 1946, soon after the creation of the Atomic Energy Commission (AEC) as the successor to the Manhattan Engineer District (MED). Quoting from my journal of December 3, 1946:

"While attending a meeting this morning, I received a telephone call from AEC Commissioner Robert Bacher (in Washington, D.C.), inviting me to be a member of the nine-member statutory General Advisory Committee to the AEC. I immediately accepted. Bacher informed me that there will be about six meetings a year; the stipend will be $\$ 50$ per day. I reported the news of my appointment to Ernest Lawrence." 


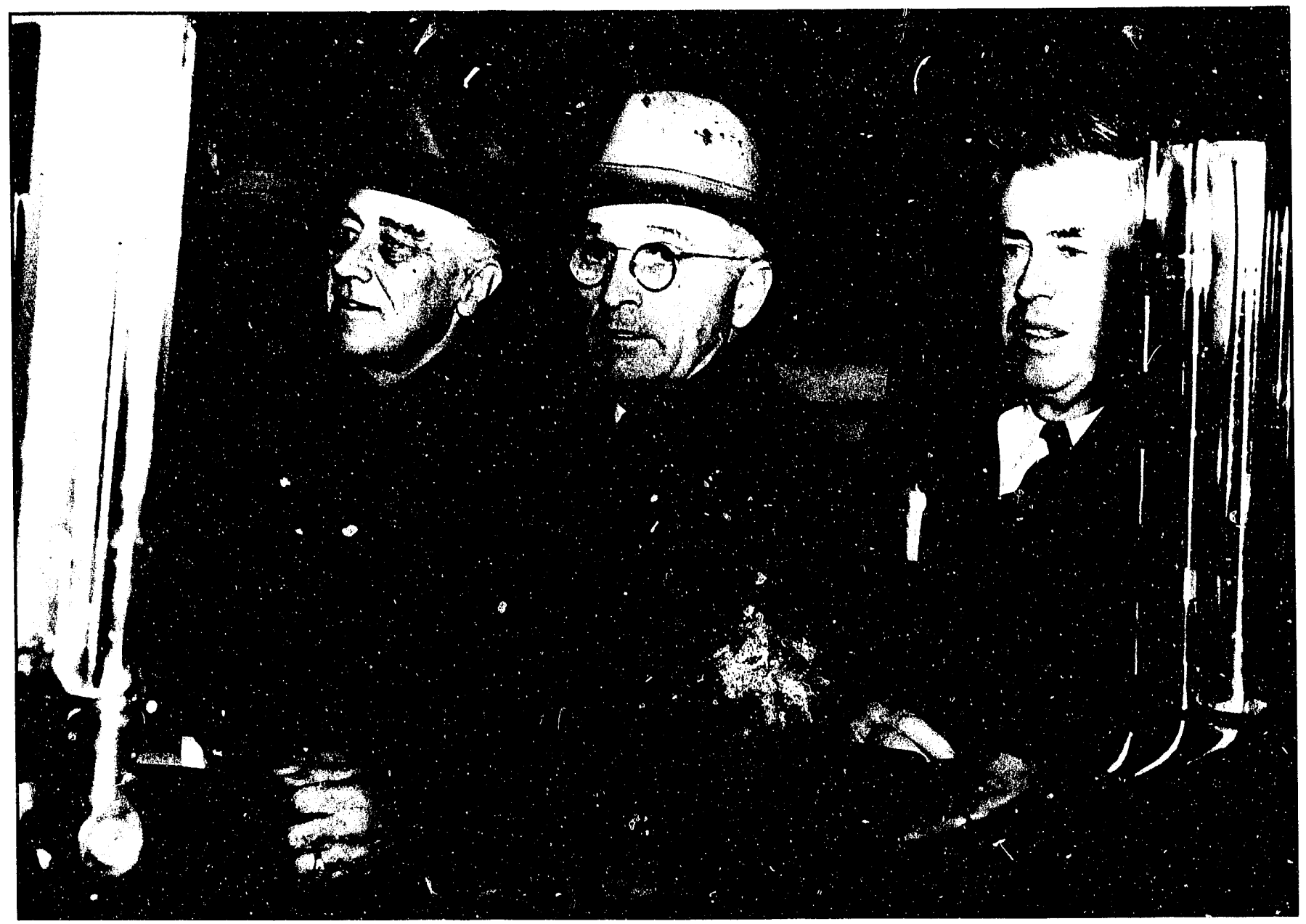

Figure 2.

(above)

Roosevelt, Vice President-elect Harry S Truman, and Vice Presiderit Henry A. Wallace at Union Station, Washington, D.C., November 10, 1944.

Figure 3.

(right)

Eleanor Roosevelt attending World's Fair in Brussels, Belgium, September 5, 1958.

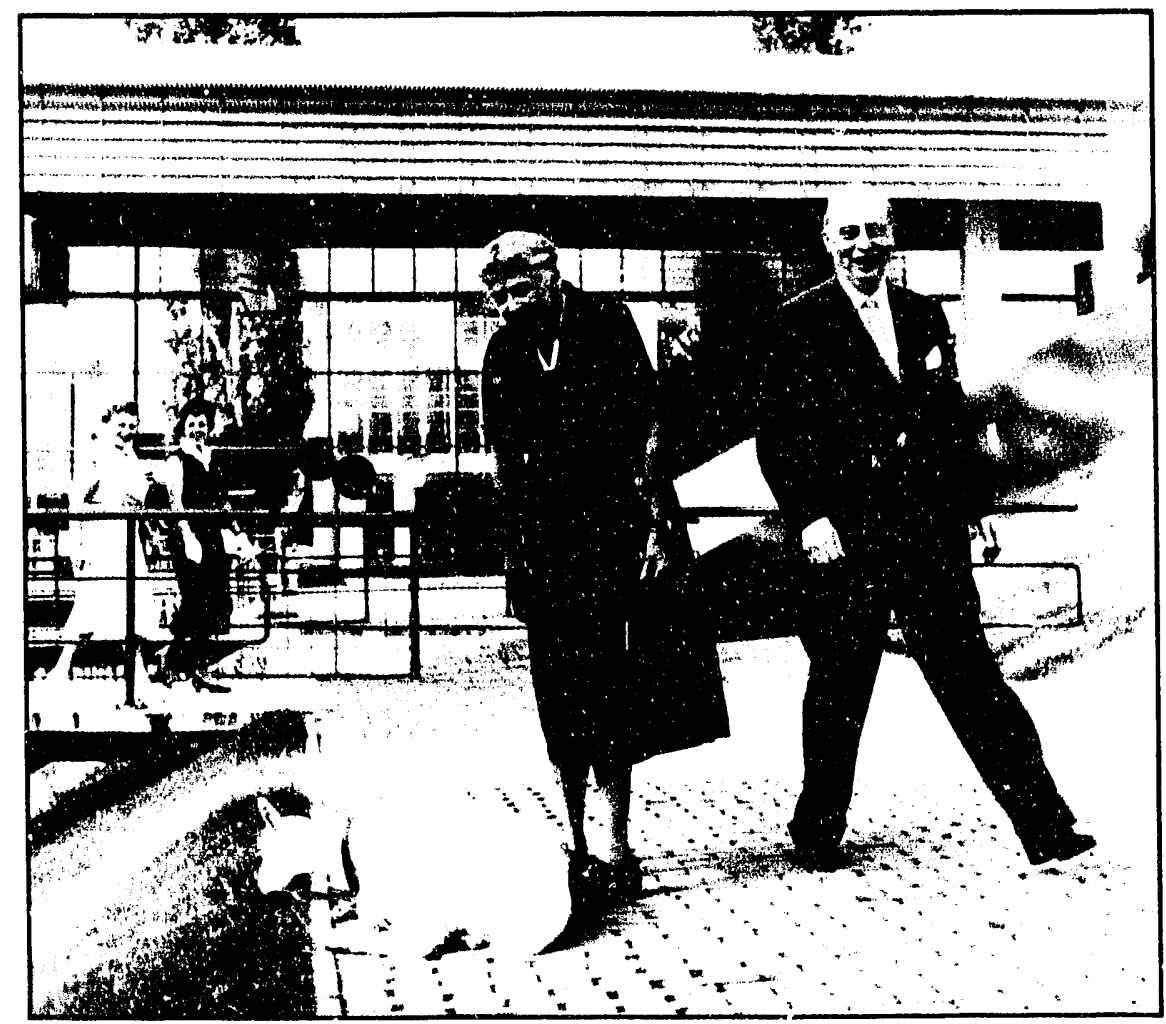




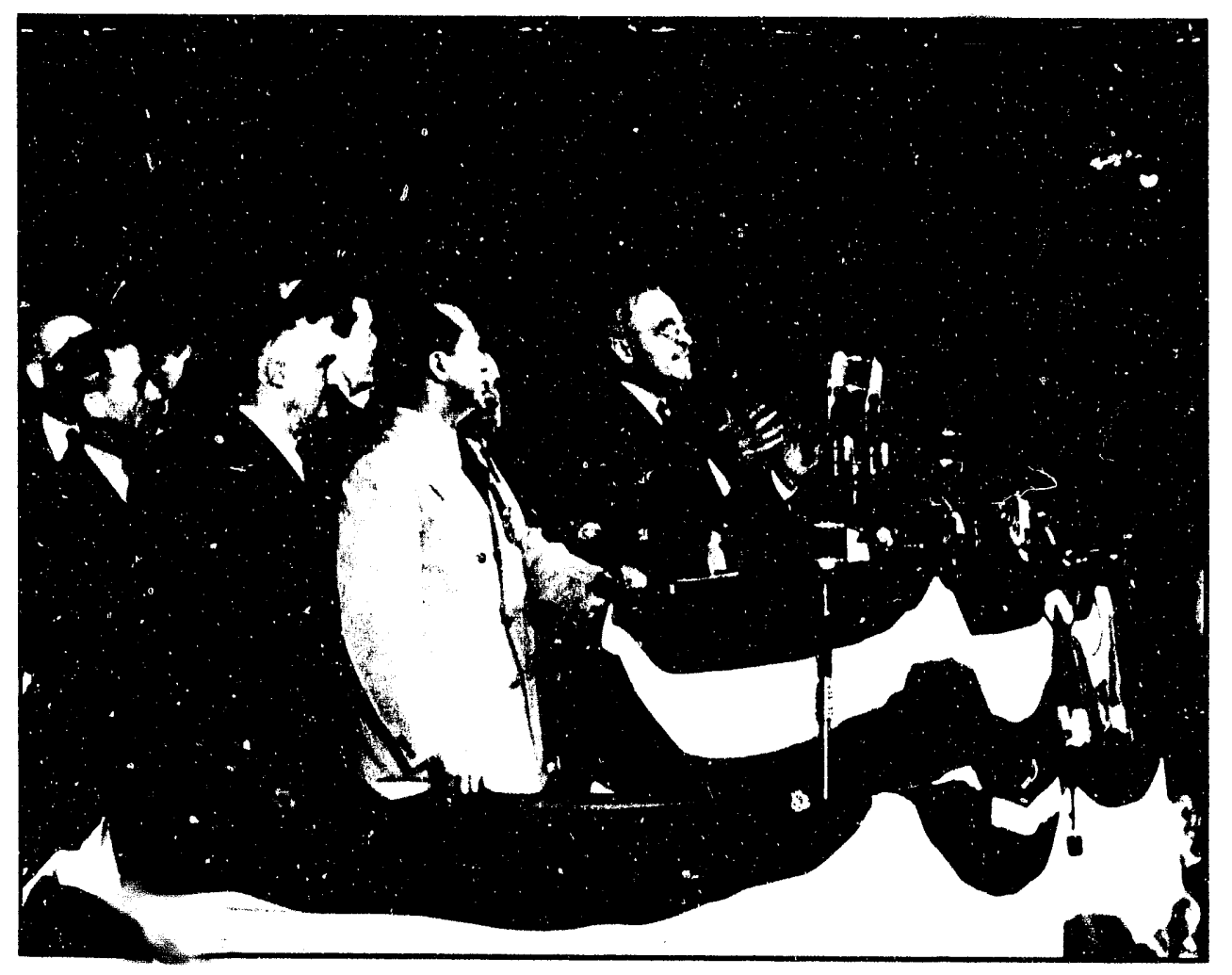

Figure 4.

(left)

Missouri Senator

Harry S Truman

accepting

vice-presidential

nomination as

Roosevelt's running

mate, Democratic

National Convention,

Corvention Hall,

Chicago, July 21,

1944.

Figure 5.

(right)

Bess Truman (left),

Truman, and daughter Margaret Truman at the Democratic National Convention, Convention Hall, Chicago, July 21, 1944.

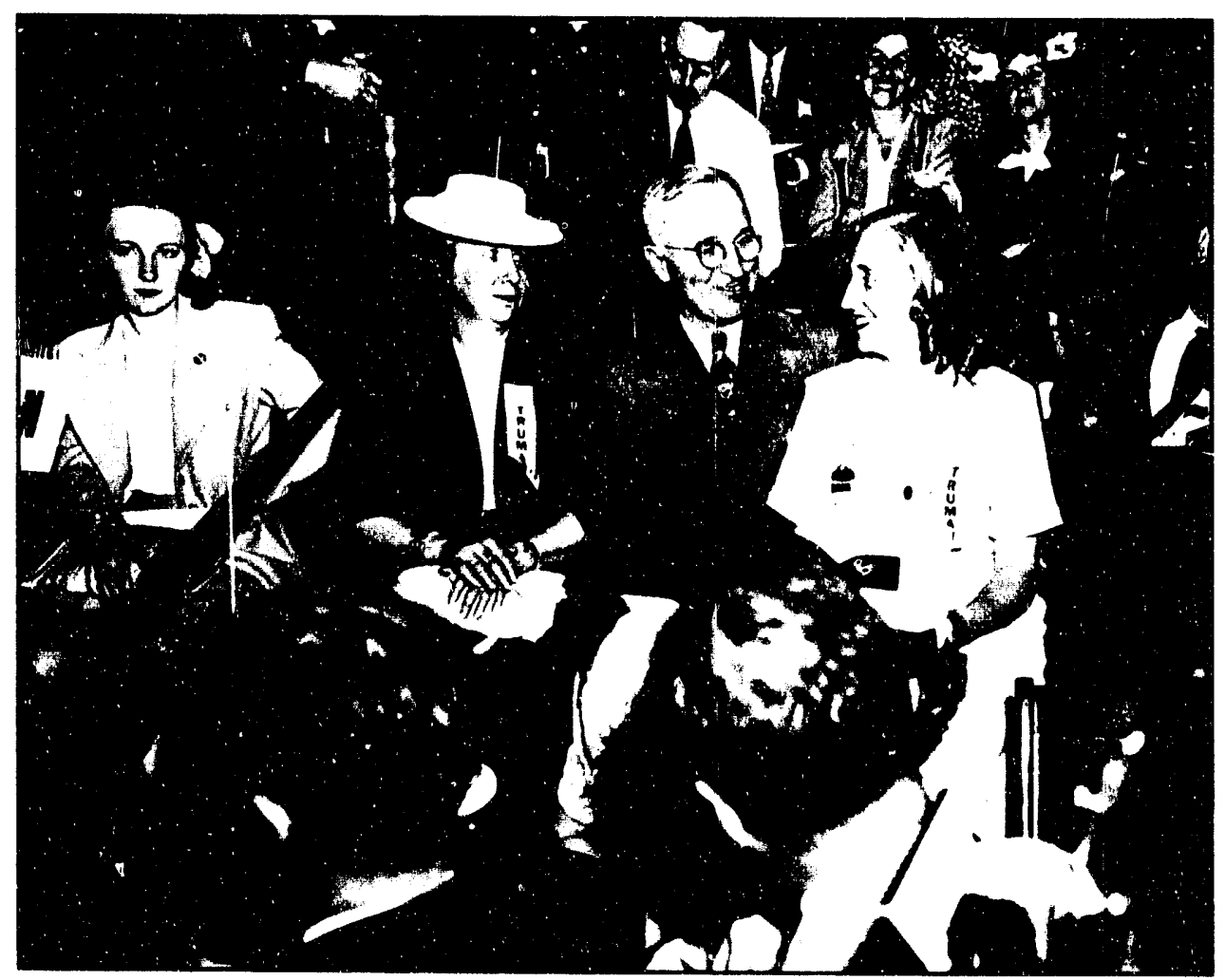


Soon thereafter, I received a letter (Figure 6.) from President Truman acknowledging my acceptance of membership on the General Advisory Committee (GAC). The initial members of the GAC were an impressive group--J. Robert Oppenheimer (who served as Chairman), Enrico Fermi, James B.

Conant, Isidor I. Rabi, Lee A. DuBridge, Cyril S. Smith, and industrialists Hood Worthington and Hartley Rowe. With such a membership, the GAC exerted tremendous influence on the initial Commissioners of the AEC--David E.

Lilienthal (Chairrnan), Lewis L. Strauss, Robert F. Bacher, Sumner T. Pike and William W. Waymack.
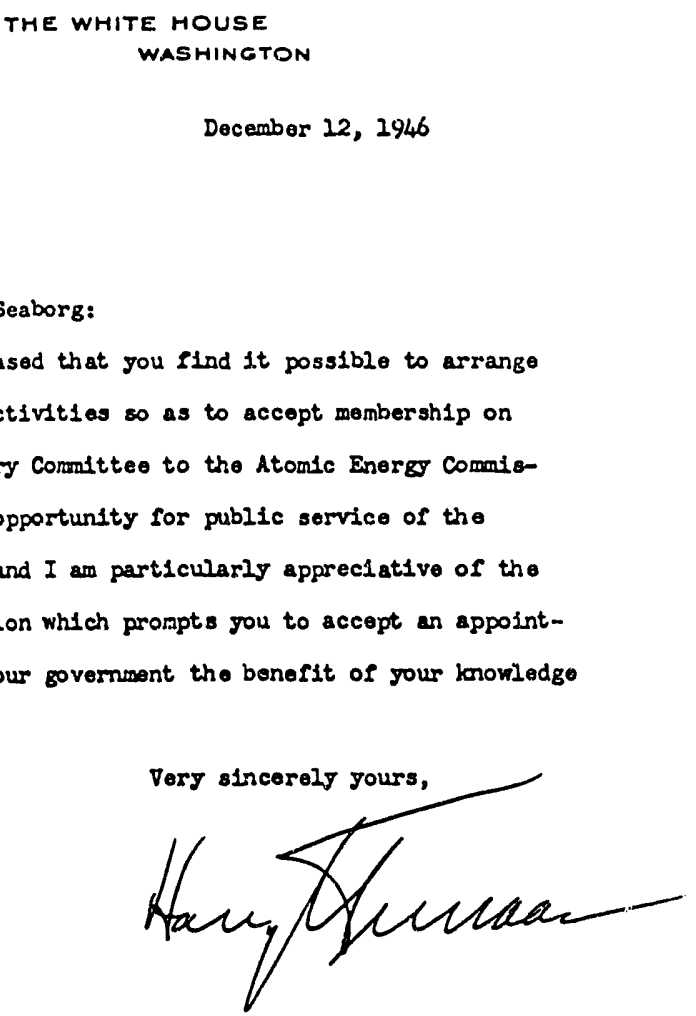

Professor Glenn T. Seaborg, University of Callfornis,

Berkeley,

California.

Figure 6. Truman's letter acknowledging Seaborg's acceptance to sarve on the General Advisory Committee of the U.S. Atomic Energy Commission (AEC), December 12, 1946.

The GAC held

its first meeting in Washington on January 3,1947 , and on the average, we met every other month. I served on the GAC to the end of my term on August 1, 1950. We were very influential in advising the AEC on the rehabilitation of the Los Alamos Weapons Laboratory (which had become somewhat disorganized after the end of the war), the operation of the AEC facilities for the production of fissionable material, the diminishing role of secrecy in the operation of the AEC, the distribution of radioactive isotopes produced in the AEC facilities, the instigation of the AEC's marvelous program of support of basic research in U.S. universities and colleges, the operation of the national laboratories, the direction of the emerging civilian nuclear power program, the AEL organizational structure, and many other areas where we thought our advice, sought or unsought, would be helpful.

A GAC action that gained the most publicity was the recommendation (at a meeting in October, 1949, which I missed due to a visit to Sweden) that the $\mathrm{AEC}$ not proceed with a high priority program to develop the hydrogen bomb. I 
had sent a letter to Oppenh'simer saying that I had reluctantly come to the conclusion that the United States should proceed with such a program because it was certain that the Soriet Union would do so. The mem.bers of the GAC learned from President Harry Truman on January 31, 1950, of his decision that the United States should proceed with the development and production of the hydrogen bomb.

I had participated earlier in an important recommendation to President Truman that was not accepted. While at the war-time Metallurgical Laboratory, I was a member of ihe "Franck Committee," which was concerned with the social and political implications of the emerging field of atomic energy in June, 1945. We were concerned especially with the frightening role of the atomic bomb which was nearly ready for use in the war with Japan. Our committee consisted of James Franck (Chairman), Donald J. Hughes, James J. Nickson, Eugene Rabinowitch, Joyce C. Stearns, and Leo Szilard. Our report, which became known as the "Franck Report," recommended that a "demonstration of the new weapon might be made, before the eyes of representatives of all the United Nations, in the desert or a barren island." This event would be followed by an ultimatum to Japan to surrender, with the implication that thus many Japanese lives would be saved. The indications are that neither the Franck Report nor petitions from scientists making a similar recommendation reached President Truman (who sailed by ship for Europe on July 6, to confer with Winston Churchill and Josef Stalin), although he may have beer briefed on the gist of the recommendations. In any case, the recommendation was not accepted.

I met Alben W. Barkley, vice president during the second Truman Administration (1949-1953), on occasions during my visits to Washington. (Figure 7.)

I met Harry Truman on a number of occasions following his presidency. I recall a memorable meeting with him (Figure 8.) at a stop in Kansas City on June 25, 1965, en route to San Francisco on Air Force One with President Lyndon B. Johnson:

"President Johnson had breakfast with former President Harry Truman. I had breakfast with Senator Frank Church in the coffee shop. I participated in a motorcade to the airport. President Johnson presented me to Truman in front of the press and news and television cameras. I recalled to Truman that I had been a member, upon his appointment, of the first GAC of the AEC."

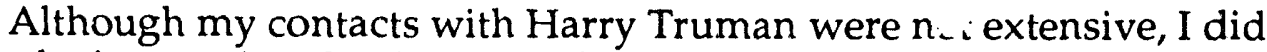
receive the impression that he was a decisive person and deserved his widespread characterization as a "no-nonsense" man of action. I am a long-time member of the Harry S Truman Library Institute (located in Independence, Missouri) and both Helen and I are regular readers of their publication The Whistle Stop. 


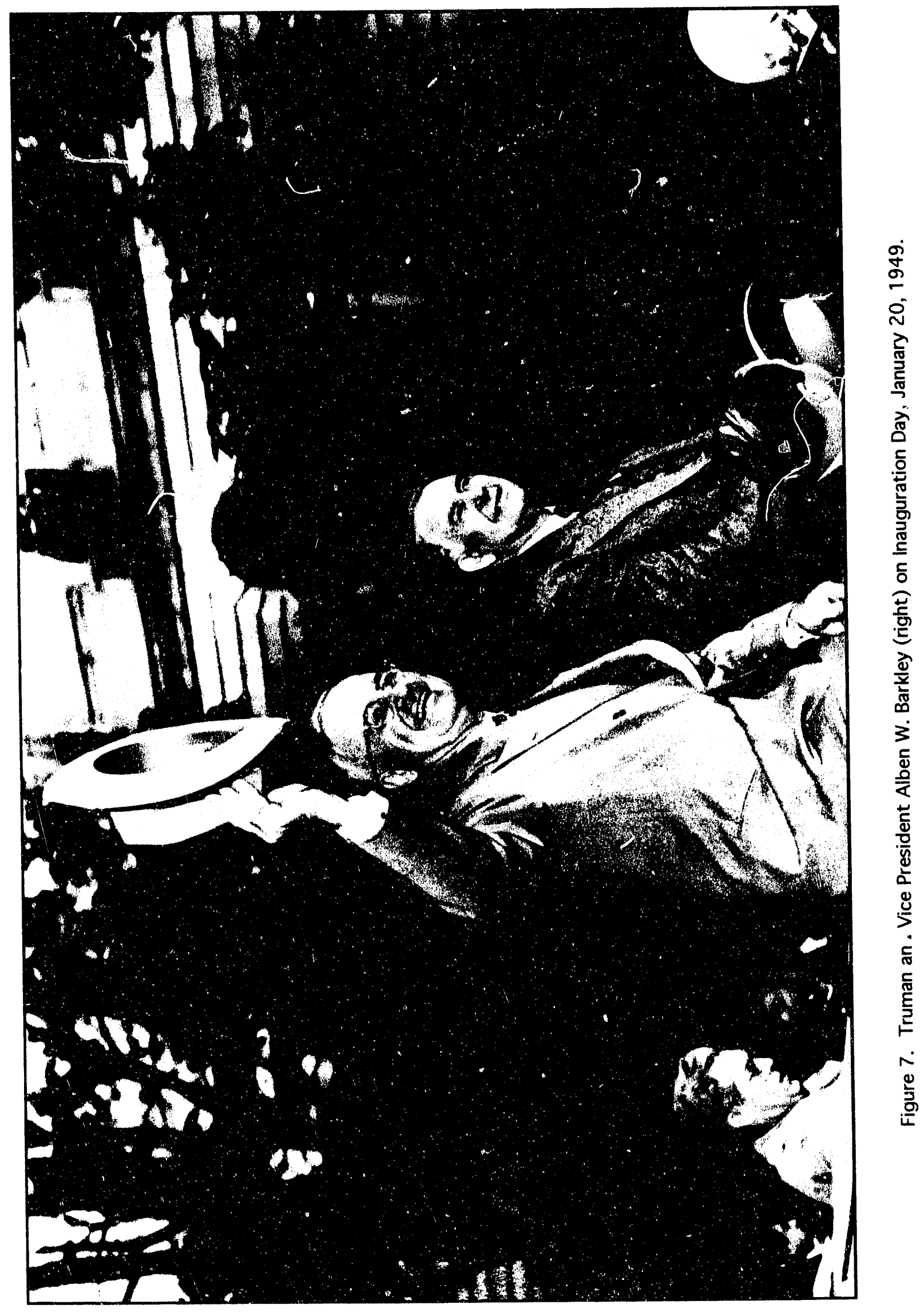




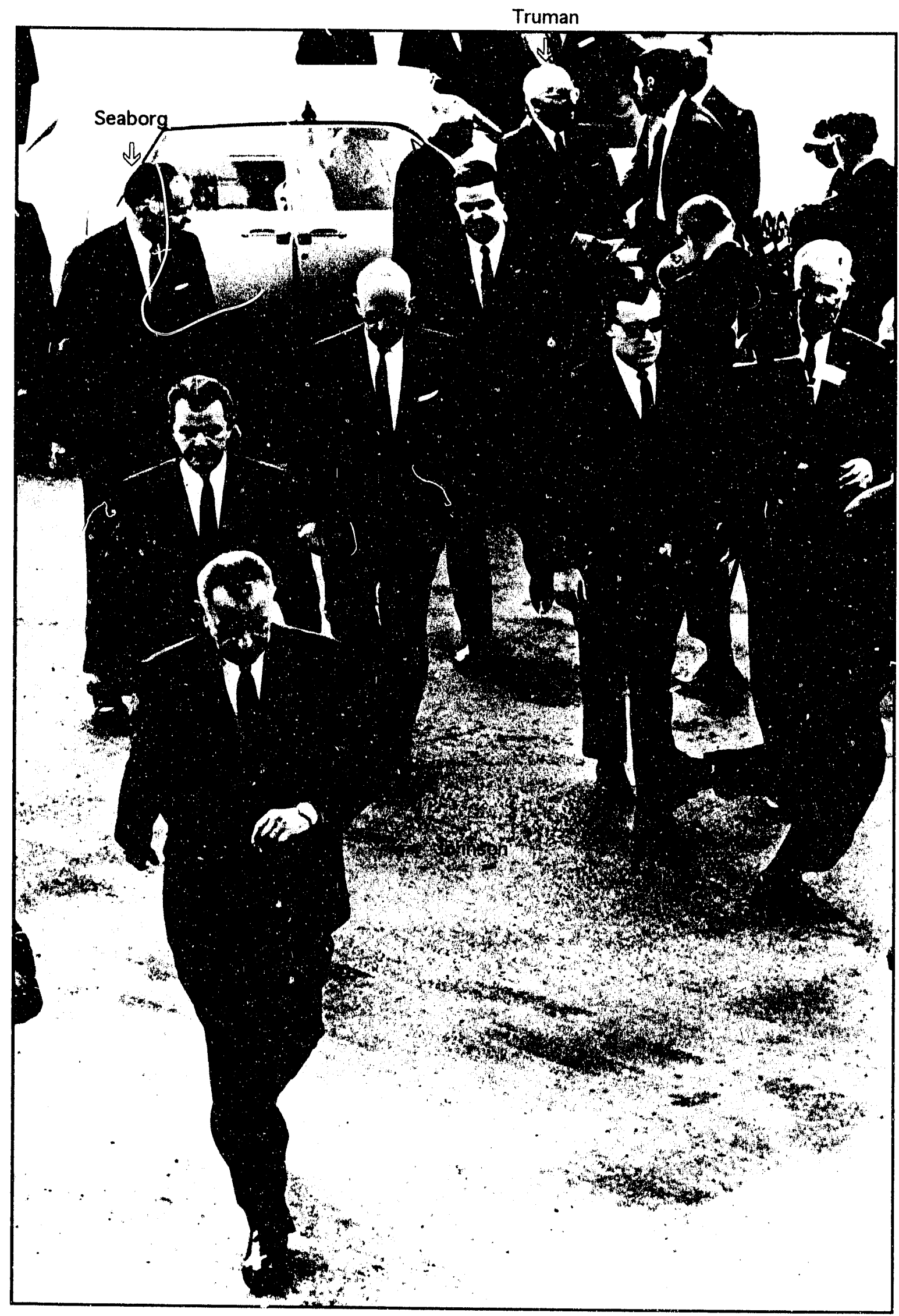

Figure 8. President Lyndon B. Johnson (lower left), Seaborg (upper left), and Truman (upper right) at the Kansas City airport, June 25, 1965. 


\section{Dwight David Eisenhower}

I had many contacts with the Atomic Energy Commission during the administration of Dwight D. Eisenhower. On October 24, 1957, I wrote to Lewis L. Strauss (President Eisenhower's Chairman of the Atomic Energy Commission) a letter of far-reaching implications for the U.S. program of transuranium element research.

"Our phone conversation last week reminded me of our earlier chat about the need for a new "very high flux reactor," and I thought that I would drop you a few lines to discuss this and some subsequent thoughts that I have had....The field of new transuranium elements is entering an era where the participating scientists in this country cannot go much further without some unified nationai effort which can only be authorized and coordinated by the Atomic Energy Commission itself.

The future progress in this area depends on substantial weighable quantities (say milligrams) of berkelium, californium, and einsteinium. The acquiring of this depends upon our countriy's entrance into a two-fold program: (1) The irradiation of substantial quantities of $P u^{239}$ as reactor fuel elements, and the re-irradiation of the products, in the presently available highest flux, high capacity, reactors to form hundred gram amounts of $\mathrm{Cm}^{244}$ and higher curium isotopes. (The similar neutron irradiation of hundreds of grams of Am241 is an alternate method for the faster production of smaller amounts of curium.) (2) The irradiation of the curium in the suggested 'very high flux reactor...'

Part (2) of this program (conversion of curium to berkelium, californium, and einsteinium) would require the suggesied "very high flux reactor." (This, of course, is only one of the needs that such a reactor would fulfill.) You will remember that I suggested to you a reactor in the flux range of 1015 to $1016 \ldots$.

I realize that the program suggested here will cost money, but I believe that the suggestion concerning part (1) of the program dovetails very well into the Commission's already planned program and available facilities and would accomplish the desired result at minimum cost and that the very high flux reactor of part (2) is a much needed and overdue Commission facility in any case. I would recommend going ahead with part (1) even if an immediate decision is not forihcoming on part (2). Whatever the decision may be, I think that it is worth recognizing clearly at this time the potentially inferior position which our country may hold in the area of the discovery of new elements a few years hence unless interlaboratory cooperative steps of this type are taken soon."

As a result, the U.S. National Transplutonium Production Program was established. I prevailed upon John McCone (Lewis Strauss' successor as Chairman of the AEC during the Eisenhower Administration) to sponsor the construction of the High Flux Isotope Reactor (HFIR) (which went into operation in 1965 at the Oak Ridge National Laboratory [ORNL]). Under my 
administrative leadership during the Kennedy and Johnson administrations, neutron irradiations at the Savannah River Plant and chemical processing of the transplutonium products at a Transuranium Processing Plant (TRU) at ORNL, laid the groundwork for the successful and effective National Transplutonium Production Program.

My first encounter with President Eisenhower came at a dinner at the White House on February 4, 1958:

"Helen and I went to a white tie dinner at the White House, first going to the East Room to assemble with the other guests, prior to passing through the receiving line to be greeted by the President and Mrs. Eisenhower. (Figure 9.) (The President was suffering from a slight cold.) We then proceeded to the west end of the White House and the State Dining Room, where Farrington Daniels escorted Helen and I accompanied Mrs. Daniels to our seats as in the following card:

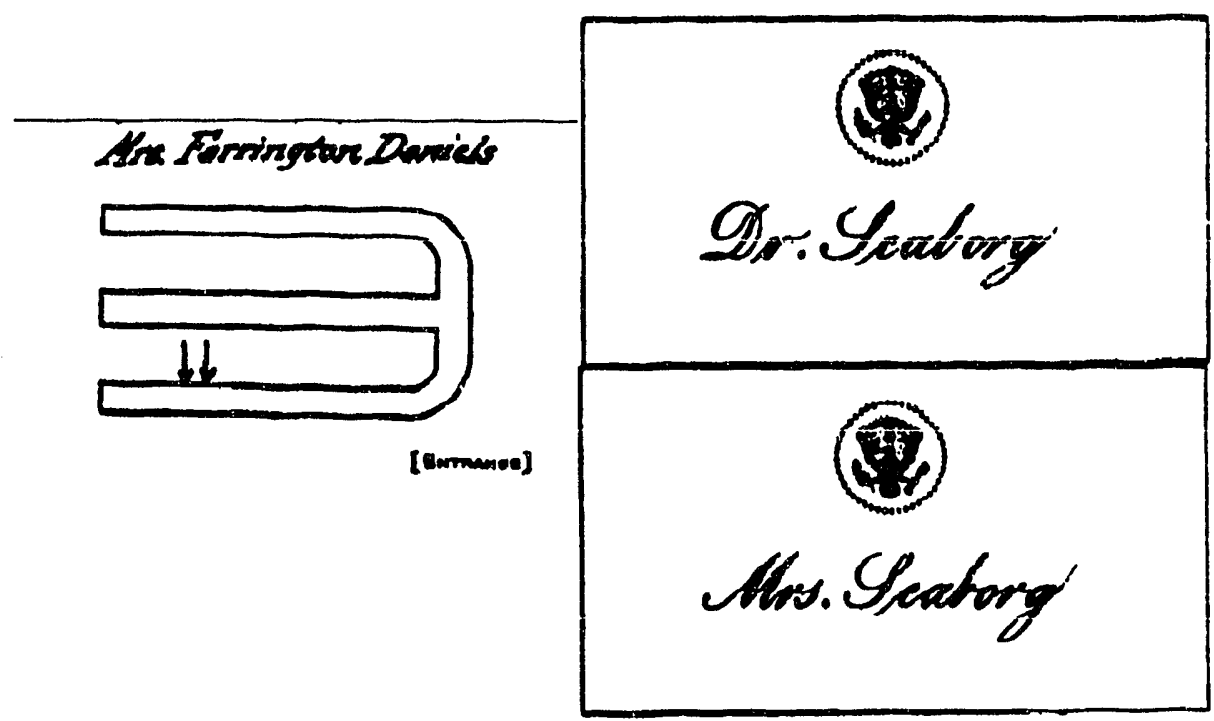

There were about 100 guests at tonight's dinner, three-tenths of whom were military, and the rest scientists and their spouses. Tables were decorated with red carnations in gold tureens. After dinner, the women accompanied Mrs. Eisenhower to the Red Room for coffee, liqueurs, and cigarettes while the men joined President Eisenhower in the Green Room for coffee, liqueurs, cigars, and cigarettes. The President spoke to some of us about the recent launching of our space satellite and the importance of science in today's society; he was very personable and approachable.

We then converged in the Blue Room, and the President greeted about 150 additional guests, including members of the Atomic Energy Commission, members of the National Advisory Committee in Aeronautics, the Little Cabinet of the Defense Department, and others.

Anna Russell (International Concert Comedian) entertained the guests in the East Room with such hilarious interpretations as a lady 
president of $a$ women's club; singing $a$ passionately sentimental song; a madrigal quartet in which she took all the parts; a skit entitled "Wind Instruments I Have Known." In the latter she put together a bagpipe with humorous remarks and vocalizing. The Marine Band played throughout the evening, and some of the guests danced to the music."

On January 26, 1959, James Killian, Chairman of the newly-created President's Science Advisory Committee

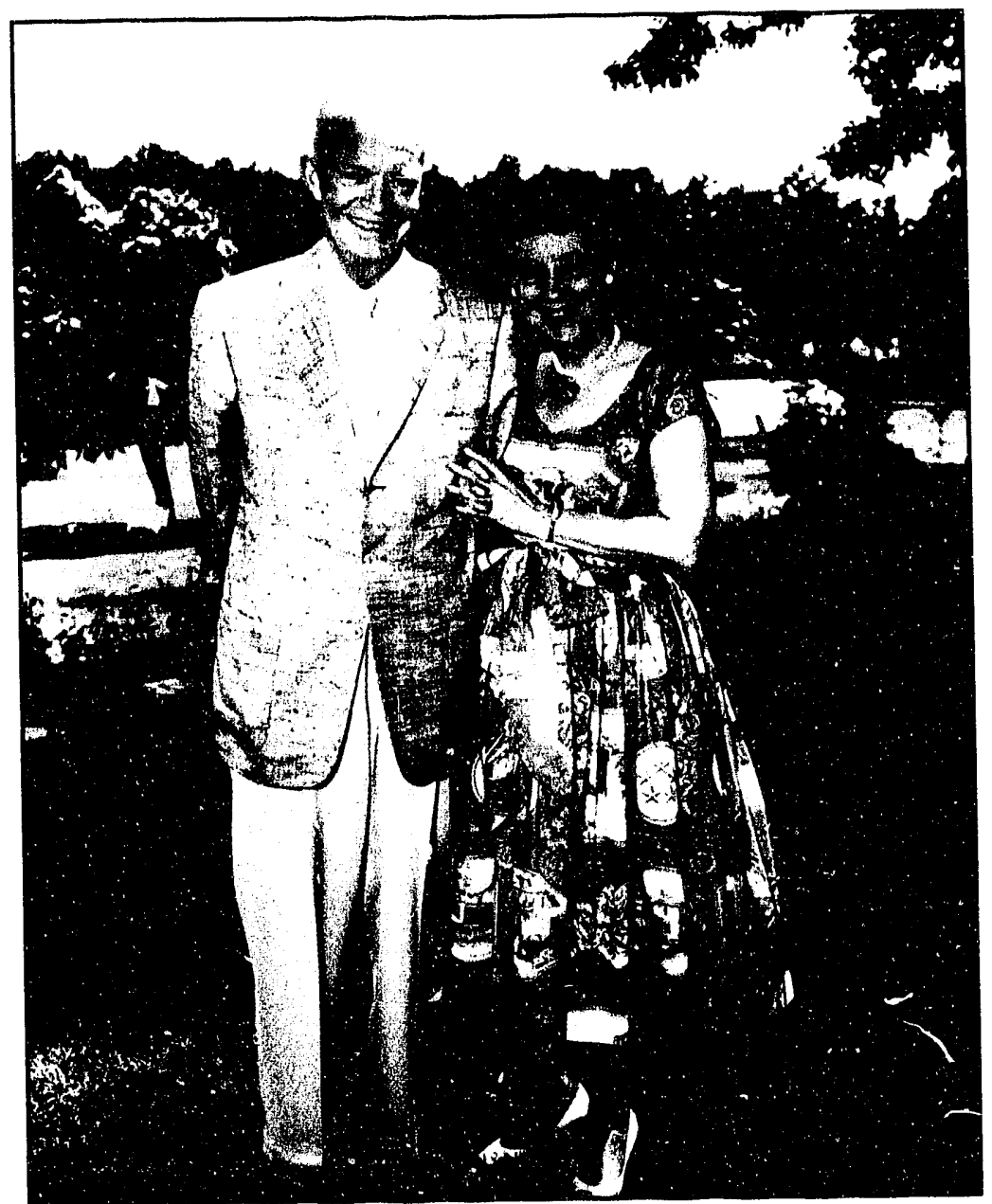

Figure 9. President Dwight D. and First Lady Mamie Eisenhower, July 1, 1958. (Eisenhowers' 40th anniversary wedding photo.)

(PSAC), extended to

me President Eisenhower's invitation to become a member of the Committee. He told me the Committee usually met on the third Monday and Tuesday of each month. I accepted with the understanding that my first attendance would be at the April meeting (April 20-21, 1959). Missing only a few meetings, I served on the PSAC until the end of Eisenhower's term as president and thus, my last meeting was on December 18-20, 1960. George Kistiakowsky assumed the chairmanship of the PSAC, effective July 15, 1959, and served until the end of Eisenhower's term.

The PSAC considered a wide range of topics, with some emphasis on military matters. Illustrative of the topics are the rames of the many PSAC Panels, consisting of members of the PSAC and additional knowledgeable scientists and engineers--AICBM, Anti-Submarine Warfare, Arms Limitation and Control, Basic Research and Graduate Education, Chemicals, Continental Air Defense, Early Warning, High Energy Accelerator Physics, Life Sciences, Limited Warfare Missiles, Science and Foreign Relations, Space Science, and Ad Hoc Missiles Study. 
The PSAC generally met in room 220 of the Executive Office Building, next to the White House, and the meeting was punctuated with lunch in the White House Mess. In February, 1960, we met at the Navy base at Key West, Florida, flying there in a special plane after taking off from Andrews Air Force Base in a heavy snowstorm. Occasionally, we met with President Eisenhower. I recal! a meeting in the Oval Office with President Eisenhower on May 19, 1959. We discussed the growing complexity in military systems (the president commented that military establishments are, and always have been, obsolete), the importance of arms control (the president agreed emphatically), the cessation of nuclear testing in the atmosphere (the president suggested that PSAC continue to advocate this), and the strengthening of science in the free world.

Our meeting on September 15, 1959, coincided with the meeting of President Eisenhower with Soviet Premier Nikita Khrushchev, so we all visited the White House lawn that afternoon to watch Khrushchev's arrival.

I served as Chairman of the Panel on Basic Research and Graduate Education. My panel finished our report, "Scientific Progress, the Universities and the Federal Government," by the time of the November, 1960, meeting of the PSAC; the report later became known as "the Seaborg Report." When the report was made available to President Eisenhower, he became so interested that he actually edited and made some changes in it. When the members of the PSAC met with the president on December 19, 1960, in the Oval Office of the White House (Figure 10.), he took special note of my PSAC Panel Report. Perhaps the report's most famous recommendation was the statement that the basis of general policy should be that basic research and the education of scientists go best together as inseparable functions of universities. Furthermore, the report also stated that federal support for basic research and graduate education in the sciences should be continued and flexibly increased, so as to support excellence where it already exists, and to encourage new centers of outstanding work.

Dwight Eisenhower was impressive in many ways, and I particularly admired his dedication to the achievement of an agreement to put an end to the testing of nuclear weapons. Helen and I were pleased to attend, on October 9-12, 1990, the observation of the centennial of President Eisenhower's birth at Gettysburg, Pennsylvania. A description of this impressive event, including the texts of the talks and discussions, has been published as a book The Eisenhower Legacy: Discussion of Presidential Leadership. We are also pleased to be readers of the publication Dateline published by the Eisenhower World Affairs Institute. 


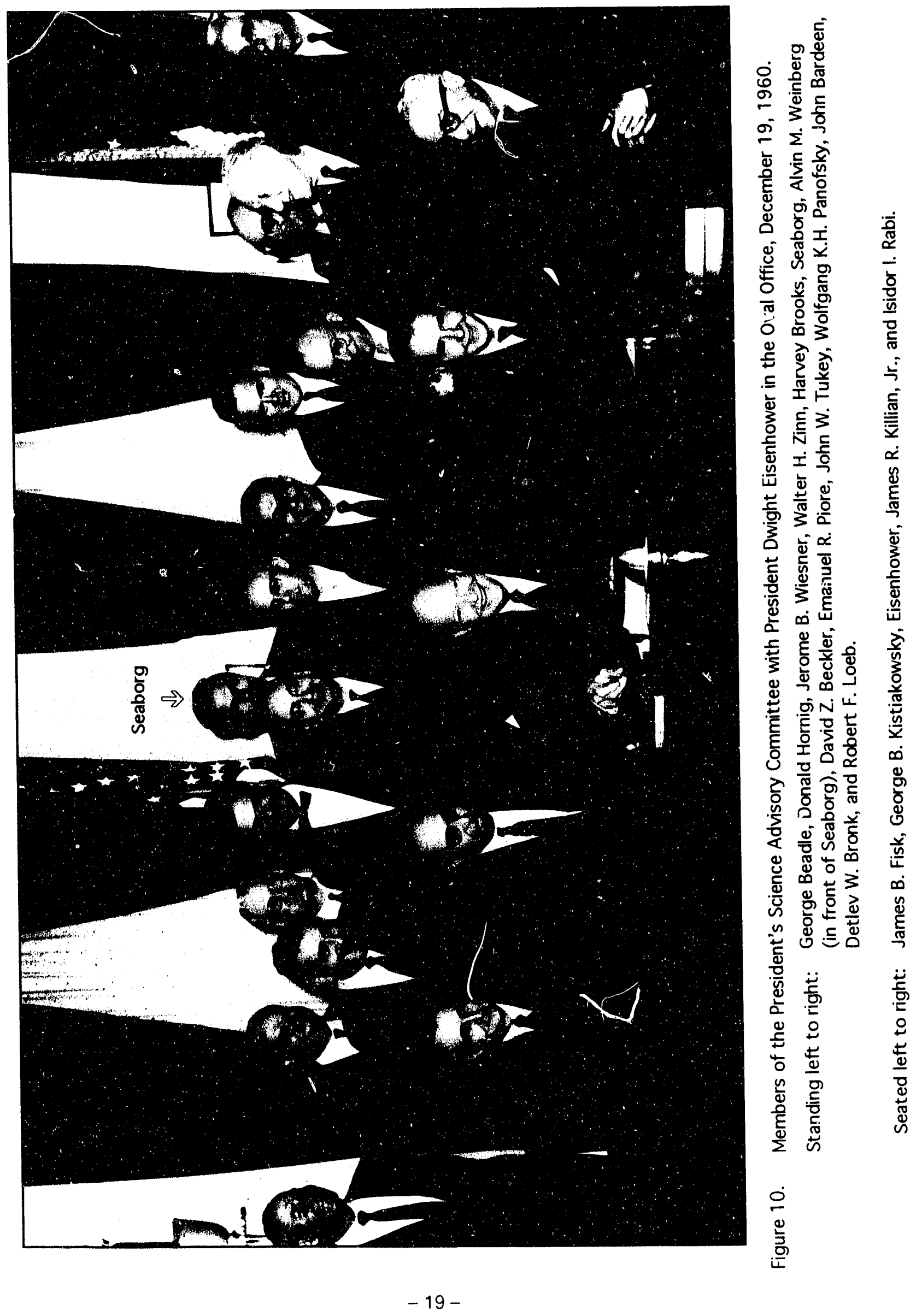




\section{John Fitzgerald Kennedy}

A telephone call that changed my life came on the afternoon of January 9 , 1961. I was in the HILAC Building of the Radiation Laboratory of the University of California at Berkeley. My habit each Monday was to take refuge there from my administrative duties as chancellor of the Berkeley campus in order to follow progress in my own academic field, nuclear chemistry. The call came from President-elect John F. Kennedy. He asked me to accept the job of Chairman of the Atomic Energy Commission. When I asked him how much time I had to make up my mind, he said, "Take your time. You don't have to let me know until tomorrow morning."

That evening I discussed Kennedy's offer of the chairmanship of the AEC with my wife Helen, and our six children. It was a big decision because we would be taking all five of our school-age children out of their schools and away from their friends. The kids did not like the idea of moving from Lafayette, California, to Washington, D.C. and during dinner, demanded a vote on this issue. The vote was seven to one against moving (with Helen and the six kids, including one-year-old Dianne, voting against.) However, I exercised the veto power inherent in the head of a democratic institution and said, "I think we should make the move."

Within a few days I accepted the offer, and I met John Kennedy on Inauguration Day, January 20, 1961. I arrived in Washington to take over my duties on January 31,1961, and my family joined me at the end of the school year in June, 1961. I accepted the position with the understanding that I would serve for the remainder of retiring AEC Chairman John McCone's term--i.e., for twoand-a-half years, until August 1, 1963. Little did I know that I would remain in this post for ten-and-a-half years, throughout the presidential terms of John $F$. Kennedy and Lyndon B. Johnson, and two-and-a-half years into the term of Richard M. Nixon. Copies of my journals are available in the three presidential libraries--in Boston, Massachusetts; Austin, Texas; and Whittier, California. These journals (AEC journals) cover for each president, the respective relevant periods of time--six volumes for February 1, 1961-November 22, 1963; eleven volumes for November 23, 1963-January 19, 1969; and eight volumes for January $20,1969-N o v e m b e r 6,1971$. Copies of the 25 volumes (plus three appendix volumes) of the AEC journals are deposited at the Lawrence Berkeley Laboratory, the Library of Congress, the Los Alamos National Laboratory, the Lawrence Livermore National Laboratory, the Bancroft Library of the University of California at Berkeley, the University of California at Los Angeles Main Library, the University of California at Santa Barbara, the Hoover Institution at Stanford University, the National Archives, the Nuclear Regulatory Commission, and the Department of Energy History Division. Also in the Kennedy Library are interviews of me, conducted in 1964 by AEC historian Richard G. Hewlett on movie film. The three presidential libraries contain many records pertaining to my service as AEC Chairman.

As AEC Chairman, I was a member of a number of inter-agency committees that existed for all or part of my tenure. Foremost of these was the Committee of Principals, which advised the president on arms 
control policy. Established by President Eisenhower, this group expanded and achieved new prominence under President Kennedy, continued to be important in the Johnson Administration, and then abandoned by President Nixon in favor of more closely held White House control. Other cornmittees whose meetings I or my designated representative attended included the Federal Council of Science and Technology (FCST, 1961-1971, composed of scientific representatives of federal agencies that had a science component in their operations); the U.S. Intelligence Board; the Federal Radiation Council (1961-1969); the President's Committee on Equal Employment Opportunity (1961-1965); the President's Science A tvisory Committee (PSAC), as an observer and as an alumnus of this committee; the National Aeronautics and Space Council (1961-1971); and the National Council on Marine Resources and Engineering Levelopment (1966-1971). Vice Presidents Lyndon Johnson, Hubert Humphrey, and Spiro Agnew served as chairmen of the Space Council, and Humphrey and Agnew of the Marine Council--I first became well acquainted with Lyndon Johnson because of his service as chairman of the Space Council.

President Kennedy had an especially close relationship with his Science and Technology Advisor, Jerome Wiesner, whom he had known since before he became president. I met with Kennedy many times in my role as Chairman of the Atomic Energy Commission--during some periods, on an almost daily basis, when such items as nuclear weapons terting and the question of a test ban were paramount issues. My contacts were on an individual basis, but more often, during meetings of the Cabinet (Figure 11.) or the iJational Security Council (or one of its subcommittees) whenever some item of interest to the AEC was discussed. I had a good deal of success in my contacts with Presicient Kennedy whenever I requested the inclusion of items of special interest to me in the $A E C^{\prime} \mathrm{s}$ budget. I recall an early meeting with him (on March 9, 1961) at which Wiesner and I convinced him to retain funds in the AEC budget for the construction of the Stanford Linear Accelerator Center (SLAC).

Shortly after the inauguration, President Kennedy very soon made an historic visit to the AEC's Germantown headquarters on February 16, 1961, traveling from the White House by helicopter. (Figure 12.) On the way, I told him a little about the AEC program. He had coffee with me in my office before meeting with the AEC staff. (Figure 13.) Following this, I gave him a short introductory briefing on the fundamentals of atomic and nuclear structure. (Figure 14.)

Quoting from my journal of February 16, 1961:

"After this, we proceeded to the Commission meeting room where all present rose to their feet. I introduced Dwight Ink, the person nearest at hand, to the President, and Bob Hollingsworth, then introduced in turn the staff members occupying front row seats as the President proceeded down the row. These included Colonel Allan Anderson, Brigadier General Austin Betts, Dr. Frank Pittman, Dr. Paul McDaniel, John Hall, Dr. Charles Dunham and Hugo Eskildson....As I escorted the President over to his seat at the far side of the voal table, the members of the President's staff, General Clifton, Dr. Wiesner and Mr. Bundy, passed down 


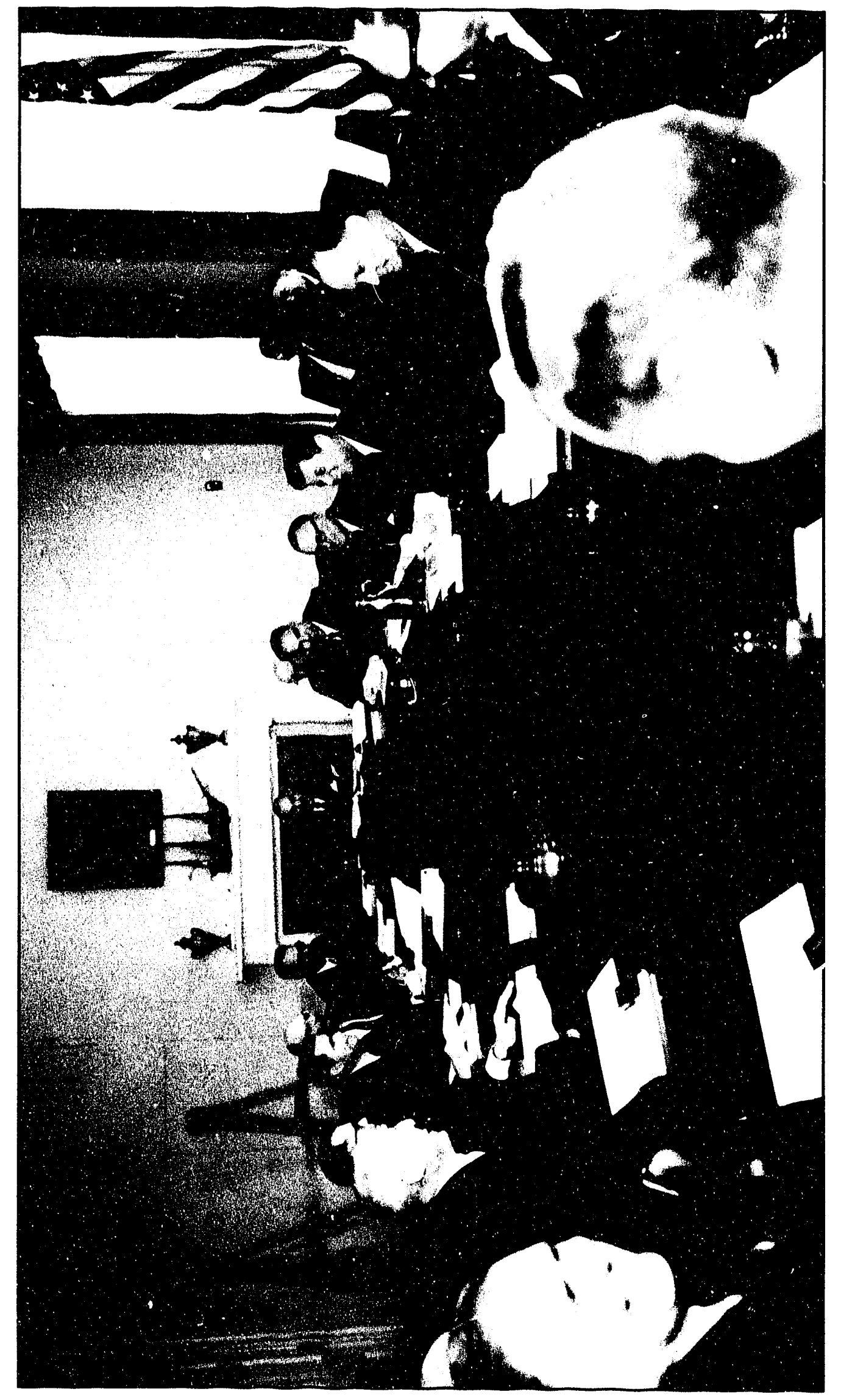

离语

边苍

is 층 용



茲㐫

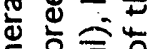

过 焉음

U ब

岃宁至

है ठิ

号乐总

选苋

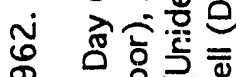

ब $0 \frac{0}{\pi} \bar{\Phi}$

क ग गे

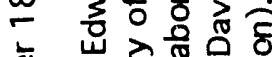

官密灾

艺

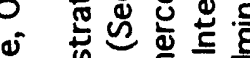

岁 莫

우 들 농홍

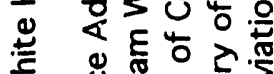

告焉

हैं 要过

है

\&

๘

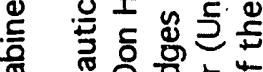

元

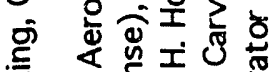

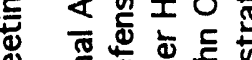

Е :

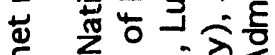

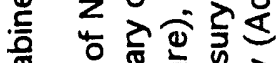

ช t

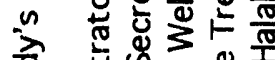

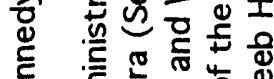

选 ह

立 है है

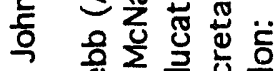

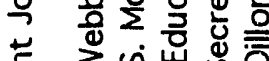

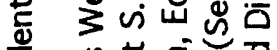

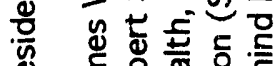

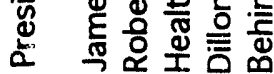

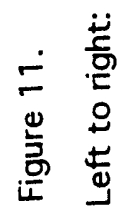




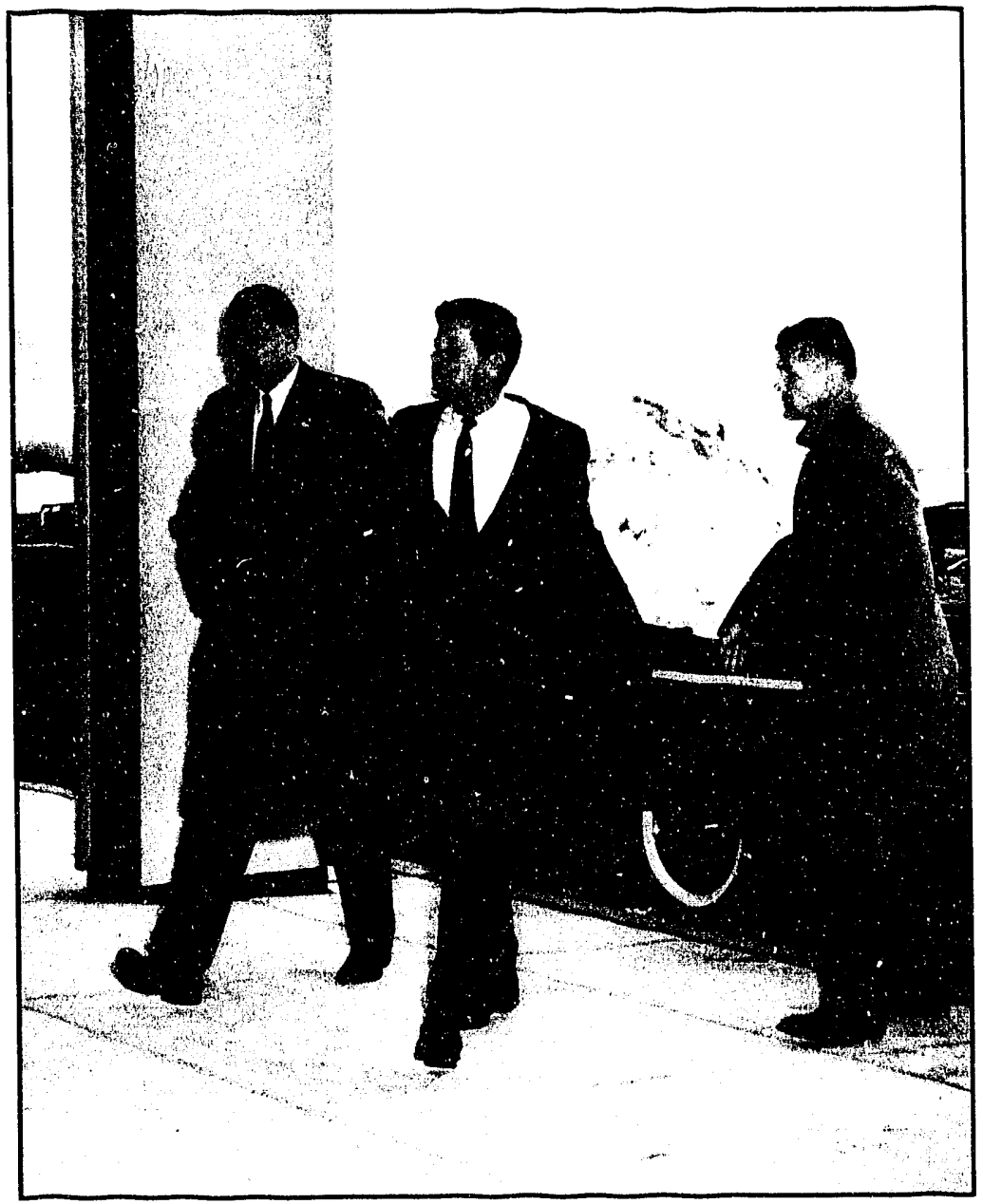

Figure 12.

(left)

Seaborg (left) and President John F. Kennedy (center)

striding into Germantown, MD headquarters of the U.S. AEC after helicopter flight from the White House, February 16. 1961.

Figure 13.

(right)

Seaborg and Kennedy enjoying cookies and coffee in Seaborg's office at the U.S. AEC headquarters, February 16, 1961.

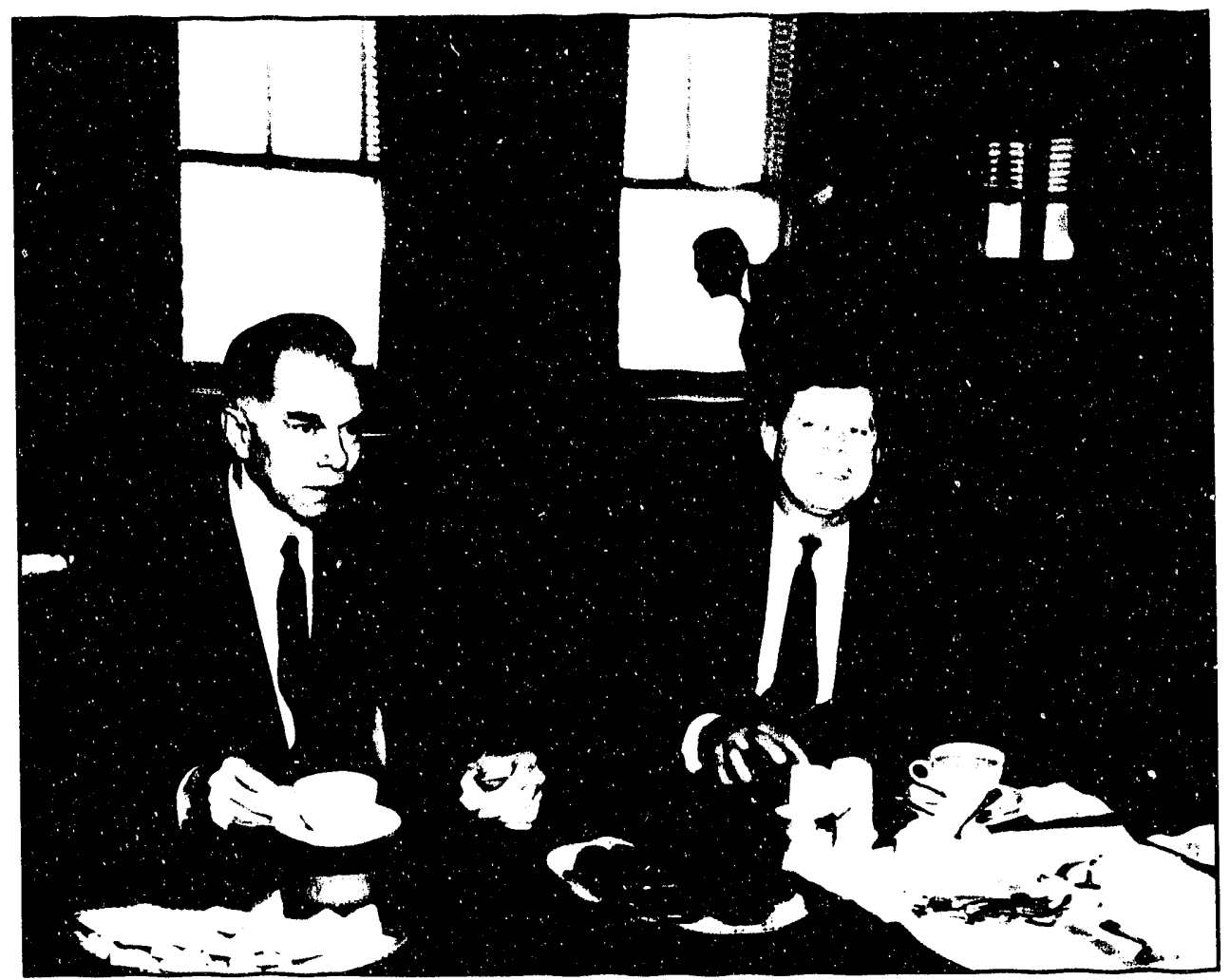




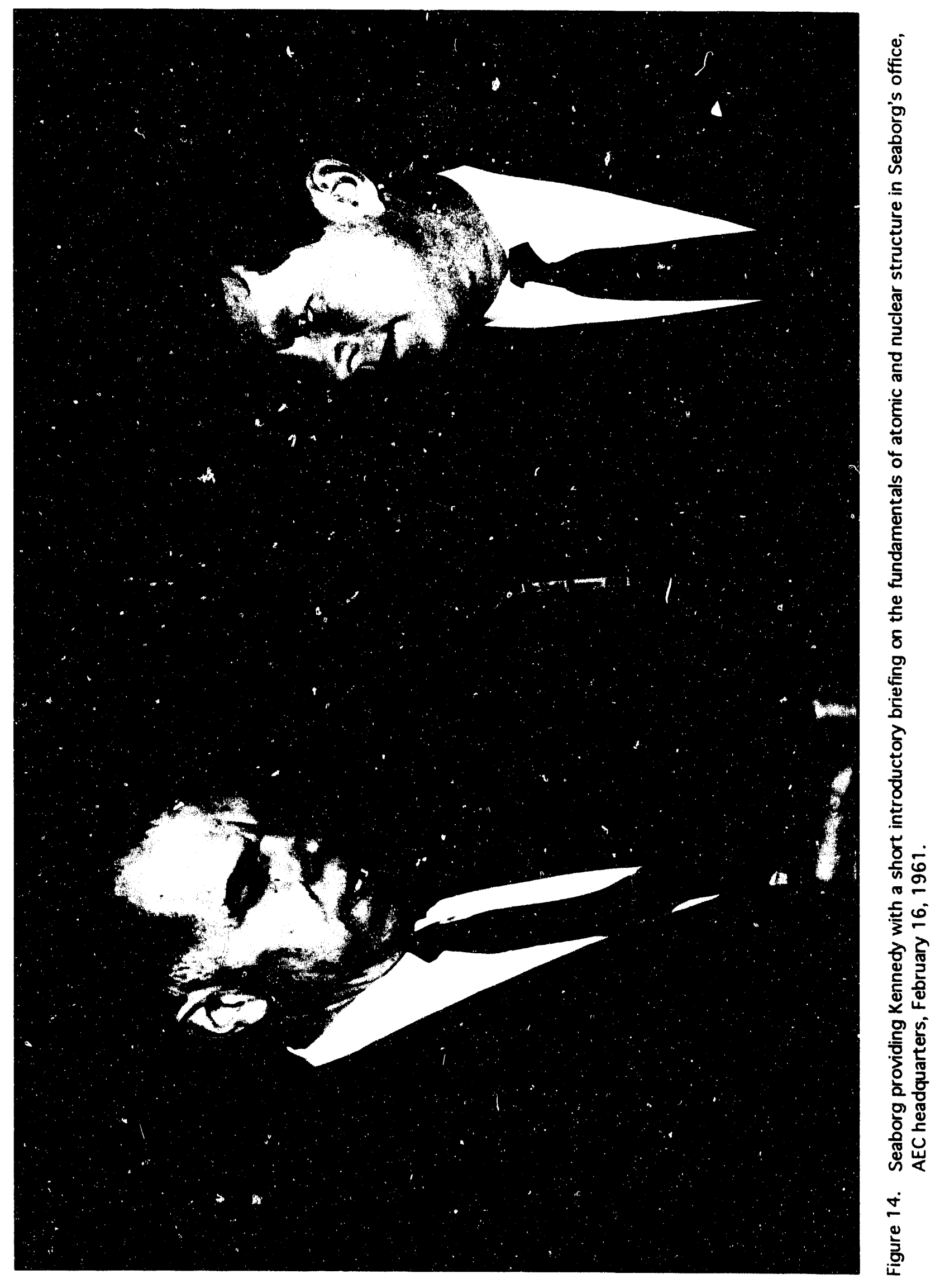


the front row introducing themselves and shaking hands with each person in that row.

All persons promptly took their places. The President's chair was in the middle of the far side of the oval table, directly opposite the lectern to be used by the speakers. Eight other officials occupied places at the table. Viewed from the lectern we were seated, left to right, as follows: General Luedecke, General Clifton, Commissioner Olson, Acting Chairman Graham, the President, myse!f, Commissioner Wilson, Dr. Wiesner and Mr. Bundy.

On the left side of the lectern and facing the President was the easel for charts; on the right side was a translucent screen for the projection of slides and transparencies. A cut-away model of a Polaris submarine, about two feet long, was on the table to the right of the lectern. Speakers and watchers were seated in three rows on the opposite side of the room from the President and behind the lectern, easel, and screen which served to obstruct their view and render them less conspicuous.

I opened the discussion at 10 a.m. with a few brief remarks on fundamental physics. I contrasted chemical energy, released through rearrangement of planetary electrons, ana nuclear energy, derived from rearrangement of particles within ihe nucleus. By way of explaining both I then contrasted fission reactions and fusion reactions and described in the simplest terms the uses, potential and actual, which man makes of these reactions with weapons, reactors, and thermonuclear devices. I pointed out that the limit to the usefulness of nuclear energy is man himself because of the effects of radiation and in this connection emphasized the Commission's concern for greater understanding of radiation effects and for protecting public health and safety. I brought out that the fission process is self-initiating and self-perpetuating at normal temperatures while the fusion process requires the creation of an environment of extremely high temperature which can be maintained only with great difficulty. I also pointed out that a very great potential advantage of the fusion reaction is the absence of residual radioactivity such as is created by fission products.

I then gave a broad-brush picture of the principal AEC activities covering: military weapons, propulsion for ships and aircraft, peaceful uses, civilian power reactors, nuclear propulsion and auxiliary power for rockets, production and use of ratioactive isotopes, research program in physics, chemistry, materials and biology and medicine, the regulatory role of the Commission, the operating budget, the value of capital plant, the number of employees, etc."

Next, AEC staff members provided briefings which took until about 11:15 a.m. I then presented to the president a number of policy questions. This took until about 12:10 p.m., much longer than planned. The president seemed to be very interested throughout, and asked many questions in the course of the briefings and policy discussions. We returned by helicopter to the White House, where we arrived at about 12:40 p.m. 
With the Soviets breaking the moratorium on the testing of nuclear weapons by their resumption of atmospheric nuclear testing on September 1, 1961 , I had many meetings with Kennedy to consider what our course of action should be. Kennedy decided that the United States would resume underground testing, and the timetable for these tests had to be worked out. Our first nuclear test took place in Nevada on September 15, 1961. We also held discussions on wheiher or not we (the U.S.) should resume atmospheric testing. I appeared (Figure 15.) on the NBC television program, "Meet The Press," on October 29, 1961, for which the president briefed me on an answer that I might give to the inevitable question concerning whether the United States had decided to resume atmospheric testing. The president told me "to be very forthcoming, but not to reveal anything of substance."

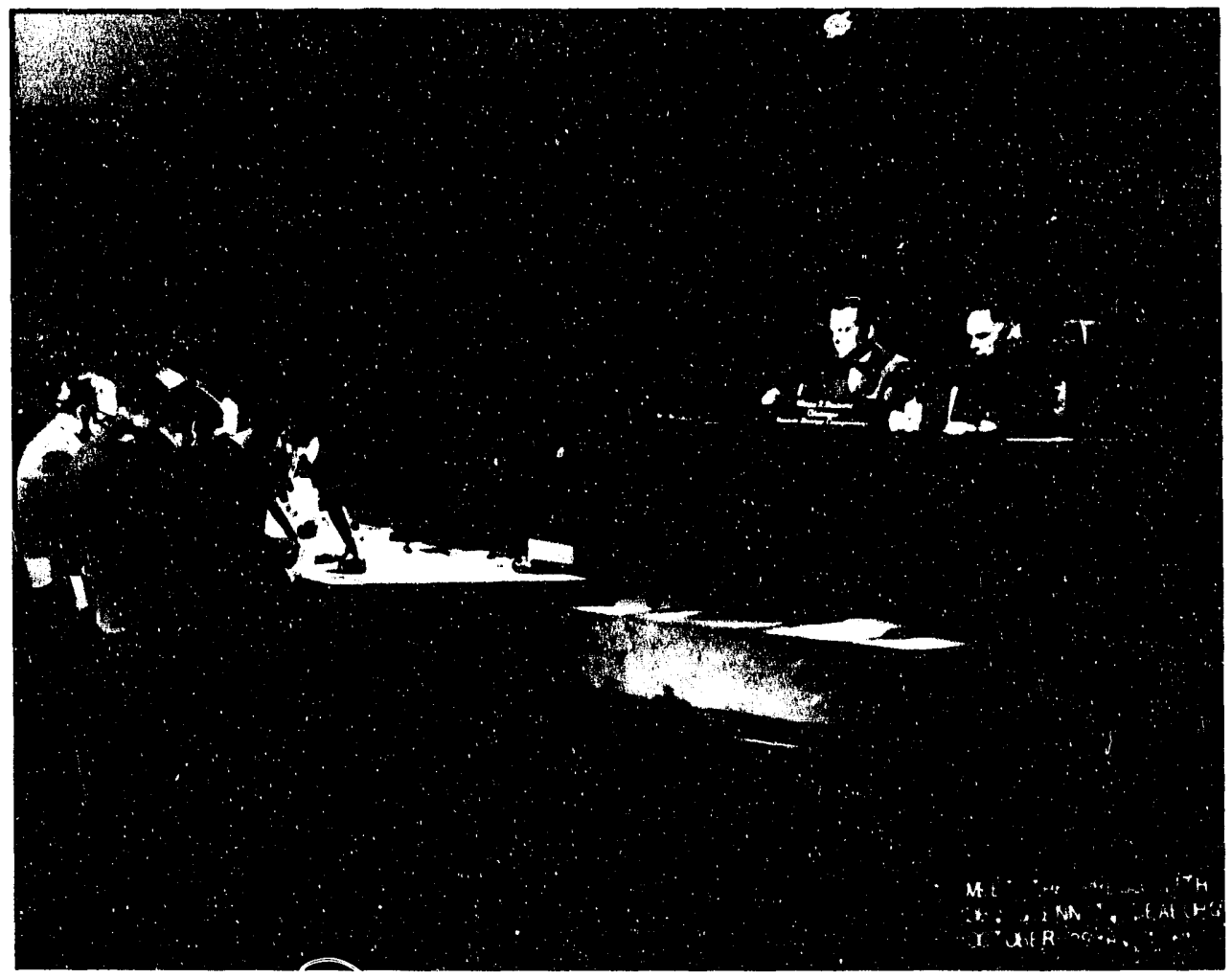

Figure 15. "Meet The Press." October 29, 1961.

Top (left to right): Ned Brooks, Seaborg.

Bottom (left to right): Lawrence Spivak, Marquis Childs, John Finney, and Peter Hackes.

The opening of the program (in which I used the guidance from President Kennedy) was as follows:

"SPIVAK: Dr. Seaborg, I know it hasn't been announced, but can you tell us--has a final decision been made yet as to whether or not the U.S. will test in the atmosphire?

SEABORG: The final decision has not been made yet, Mr. Spivak. 
SPIVAK: $\quad$ Can you tell us when it will be made?

SEABORG: $\quad$ No, I can't tell you when it will be made--if it will be made.

SPIVAK: $\quad$ Can you tell us what the final decision will be based on?

SEABORG: Well, the final decision will be made by the President, of course, and I suppose that he would want to base it in large part on the result of the analysis of the Soviet tests. I would also suppose that he would never take this decision to test in the atmosphere on the basis of political or terroristic considerations, such has been at least part of the reason for the Russian testing, but would base his decision entirely on the technical need for the information in the interests of our national security."

I spent a very interesting half-hour responding to the persistent questions of Lawrence Spivak (the permanent member of the "Meet the Press" panel), Marquis Childs (a widely syndicated newspaper columnist), John Finney (the aggressive New York Times, reporter), and Peter Hackes (NBC News).

One of the most important sessions on nuclear weapons and related security matters was held at the presidential summer home in Palm Beach, Florida, just before Christmas, on December 20, 1961. On this occasion, we ate dinner in the family dining room where I had the pleasure of sitting next to Jacqueline Kennedy, whom I found to be a very interesting conversationalist. The next day I flew with the president and his party to Bermuda for a two-day meeting in Bermuda with United Kingdom Prime Minister Harold Macmillian ana suo ai :'isors, including Sir William Penny (Chairman of the United Kingdom's Atomic Energy Authority). My memory of the Kennedy in these early meetings, an image strengthened and reinforced as time went on, is of a man remarkable for his immediate grasp of ideas, his ability to arrive at the gist of a discussion, and his eloquence in summarizing the main points at issue.

He was the first president to make a personal presentation of the Atomic Energy Commission's highest honor, the Enrico Fermi Award; he made these presentations in 1961 and 1962, and had planned to do so again on December 2, 1963. On the first of these occasions--the presentation of the Fermi Award to Hans Bethe in the White House in 1961--the camera caught all of us smiling when I somewhat tardily handed over the $\$ 50,000$ check for the president to present to Dr. Bethe--the president having just read the citation in tones of convincing finality. (Figure 16.)

Helen and I flew with President Kennedy and his entourage on Air Force One to California on March 23, 1962, when he gave the University of California's Charter Day address in Memorial Stadium. 
We flew from

Andrews Air Force

Base to Alameda

Naval Air Station, leaving at 8:50 a.m. and arriving at 10:55 a.m. Others in the party included California Senator Clair Engle and Congressmen George Miller and Jeffrey Cohelan. I participated in a parade (with the president, Ed Pauley, and Governor Pat Brown in the lead car) through Alameda, Oakland, and Berkeley. The presidential party then proceeded to the Radiation Laboratory where, in Building 70A, (Figure 17.) we briefed the president using a display of model weapons and command-and-control devices. Robert

McNamara, Harold Brown, Norris Bradbury, John Foster,

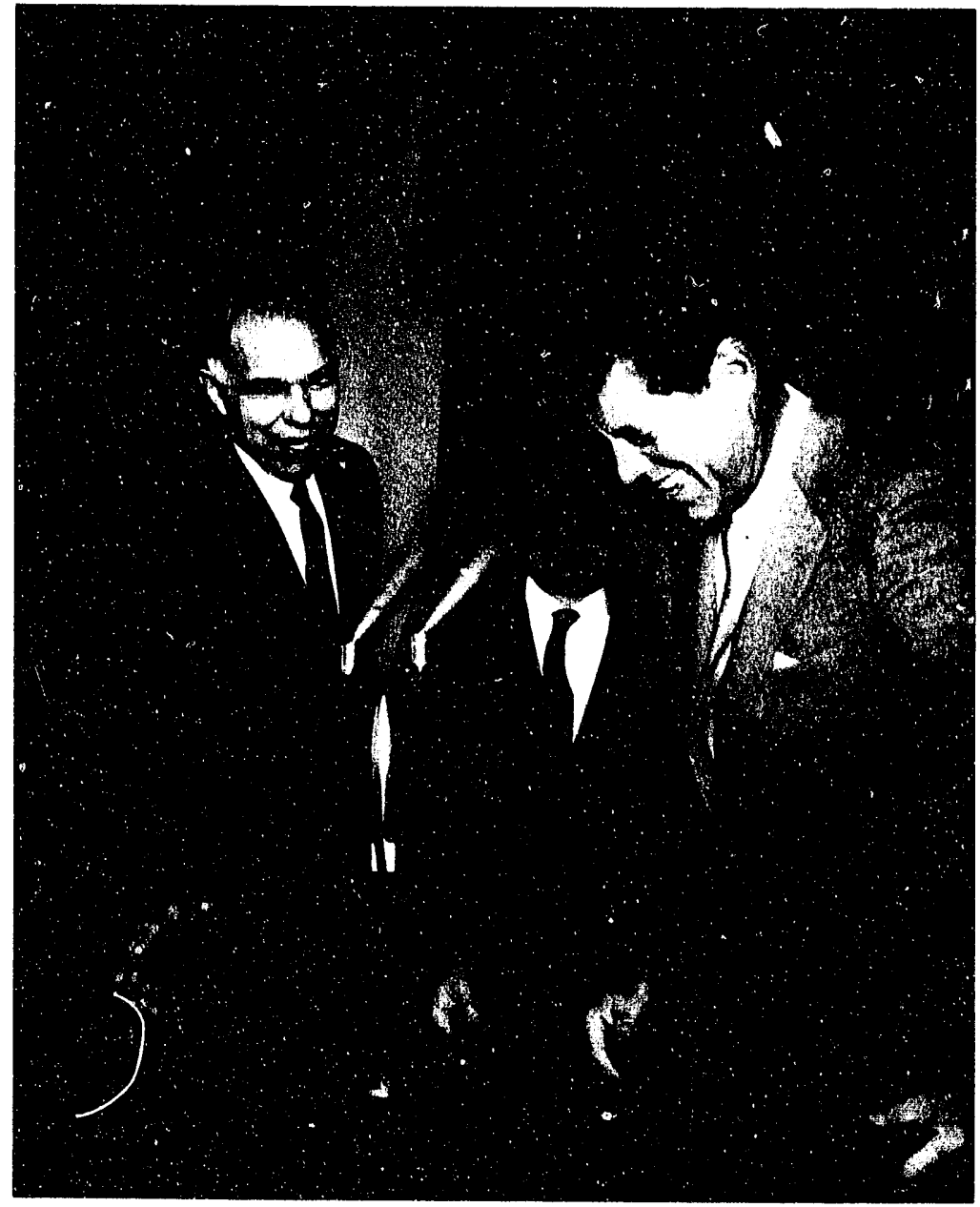

Figure 16. Seaborg (left) and Kennedy presenting AEC's Enrico Fermi award to Dr. Hans Bethe (center), December 1, 1961. Mrs. Bethe standing behind Kennedy.

Edwin McMillan,

Edward Teller, Roger Batzel, Carl Haussman, Marvin Martin, Ted Merkle, Duane Sewell, Duncan McDougall, Robert Frohn, and Michael May were present.

We then went to University House on campus, where Kennedy met U.C. President Clark Kerr, the Regents, chancellors from other campuses, deans and so forth, and their wives. After lunch, we went to Memorial Stadium, where after the inauguration of Ed Strong as Chancellor (of U.C. Berkeley), the president spoke to a crowd of 85,000 to 90,000 people, occupying all the seats and covering the floor of the stadium. (Figure 18.) He gave an inspiring address, speaking largely extemporaneously, though he had a prepared text to which he could refer. He opened with personal references to a number of the Berkeley people in his administration about whom I had briefed him during the airplane ride on the way out in the morning. 


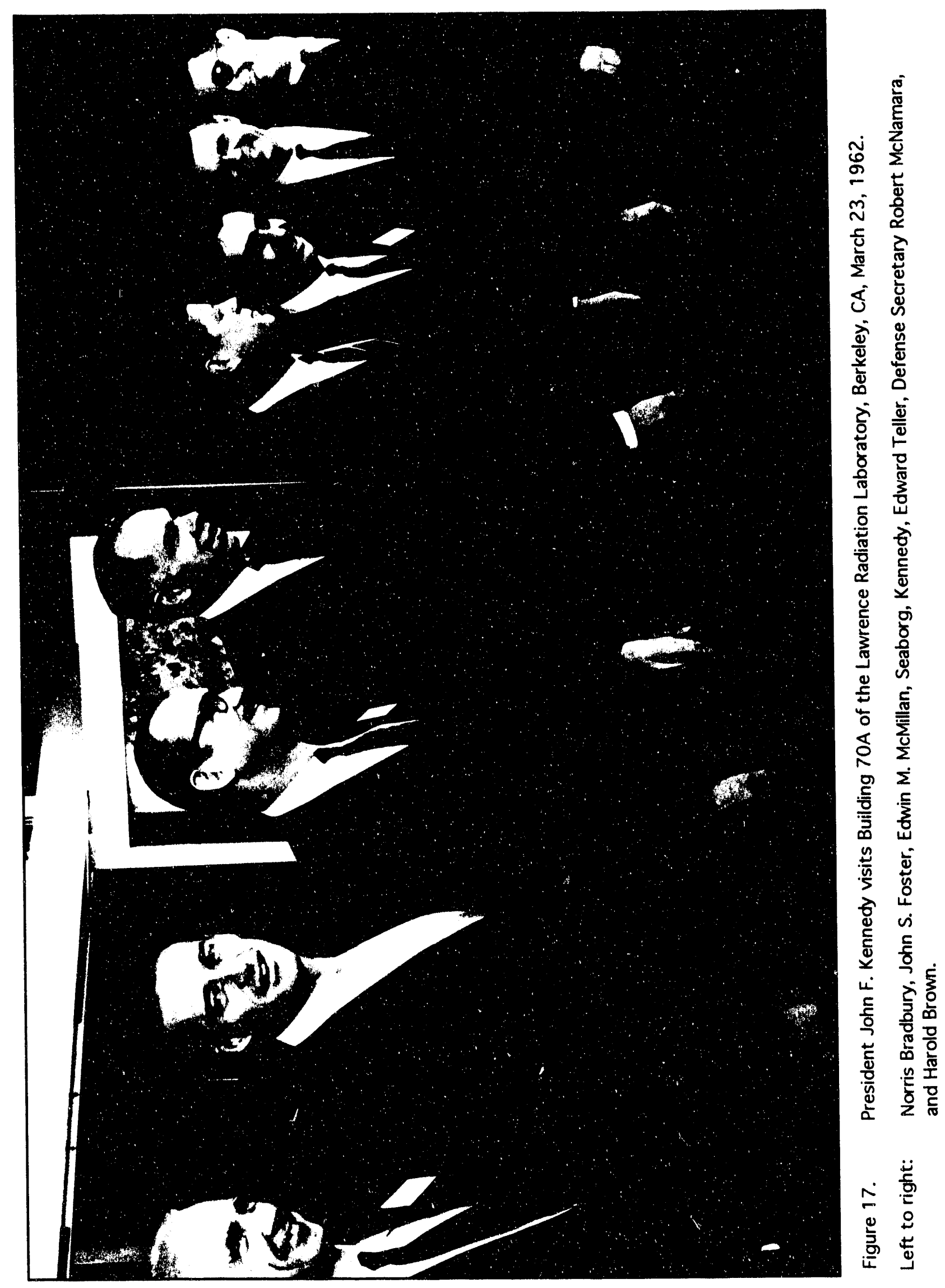




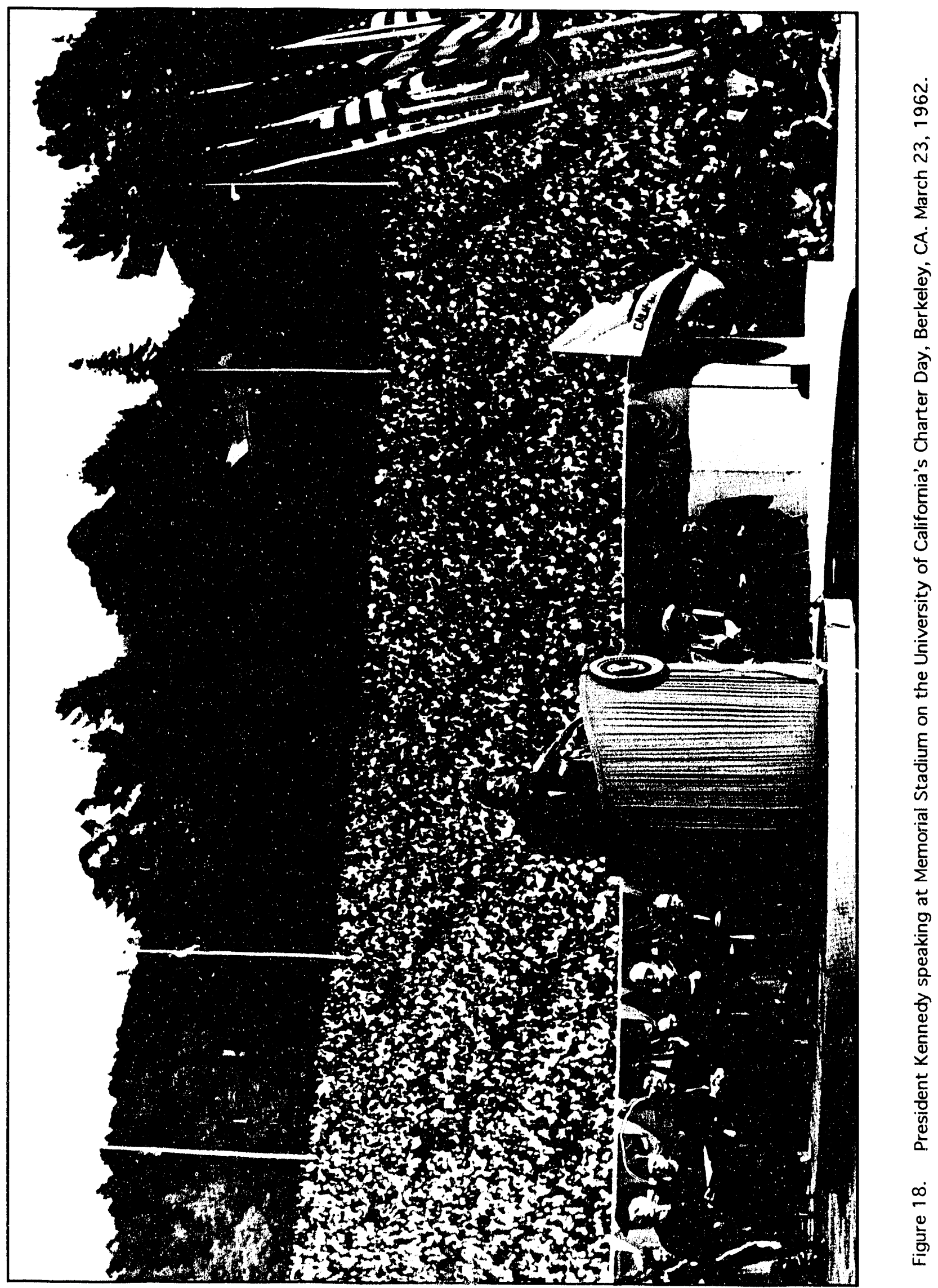


Helen and I were privileged to attend the famous dinner for Nobel Prize winners held in the White House the evening of April 29, 1962. There were 49 Nobel Prize winners, most with their wives and including one woman Nobelist, Pearl Buck among the 175 guests at this black tie dinner. The winners of the Nobel Prize the previous year were the featured guests--Melvin Calvin (Chemistry), Robert Hofstadter and Rudolf Mossbauer (Physics), and Georg von Bekesy (Physiology or Medicine). The assembled group of 49 Nobel Prize winners had our pictures taken with President and Mrs. Kennedy, and including such people as Mrs. Ernest Hemingway and Mrs. George C. Marshall. (Figure 19.)

The president spoke in the State Dining Room where he was seated at one of 14 festively decorated tables, where I was also seated. A loudspeaker beamed his words to the neighboring Blue Room where First Lady Jacqueline Kennedy presided over five additional tables, and where Helen was seated.

It is on this occasion that Kennedy made his famous extemporaneous remark, "I think this is the most extraordinary talent, of human knowledge, that has ever been gathered together at the White House, with the possible exception of when Thomas Jefferson dined alone."

Among the 175 people present, including in many cases, spouses, were Lester Pearson, Robert F. and Ethel Kennedy, astronaut John Glenn, John Dos Passos (writer), Robert Frost (poet), Lee DuBridge, James Killian, George Kistiakowsky, Robert Oppenheimer, Alan Waterman, Jerome Wiesner, Clark Kerr (President of the University of California), Nathan Pusey (President of Harvard University), and Norman Cousins (writer). Gold cloths covered the tables in the State Dining Room and the Truman China with green and gold borders was used. In the Blue Room, the cloths continued the blue theme while the Harrison China with blue and gold bands was used there.

In a conversation with Robert Oppenheimer, I asked if he would accept the Fermi Award if offered, and he replied that he would. In reply to another question, he indicated that he wouldn't want to go through another hearing process to get his security clearance renewed.

After dinner, when we had assembled in the East Room, we were privileged to hear Frederic March perform. He read three works by past Nobel Prize winners. One was a short foreword by the late novelist Sinclair Lewis. March followed this by reading the stirring words spoken by General George C. Marshall when, as Secretary of State, he spoke at Harvard University upon the inception of the Marshall Plan. Lastly, March recited a moving chapter from an unpublished novel of the sea by the late Ernest Hemingway.

In December, 1962, I visited the Los Alamos Laboratory, the Sandia Laboratory, and the Nevada Test Site with President Kennedy. I recall flying over the Sedan Crater with him and remember his fascination with the size of the hole (1500 feet in diameter and 400 feet deep). He wanted his helicopter pilot to land on the crater's edge for a closer look. When the pilot, after some difficulty, persuaded the president that the dust might be deep and cause a problem in 


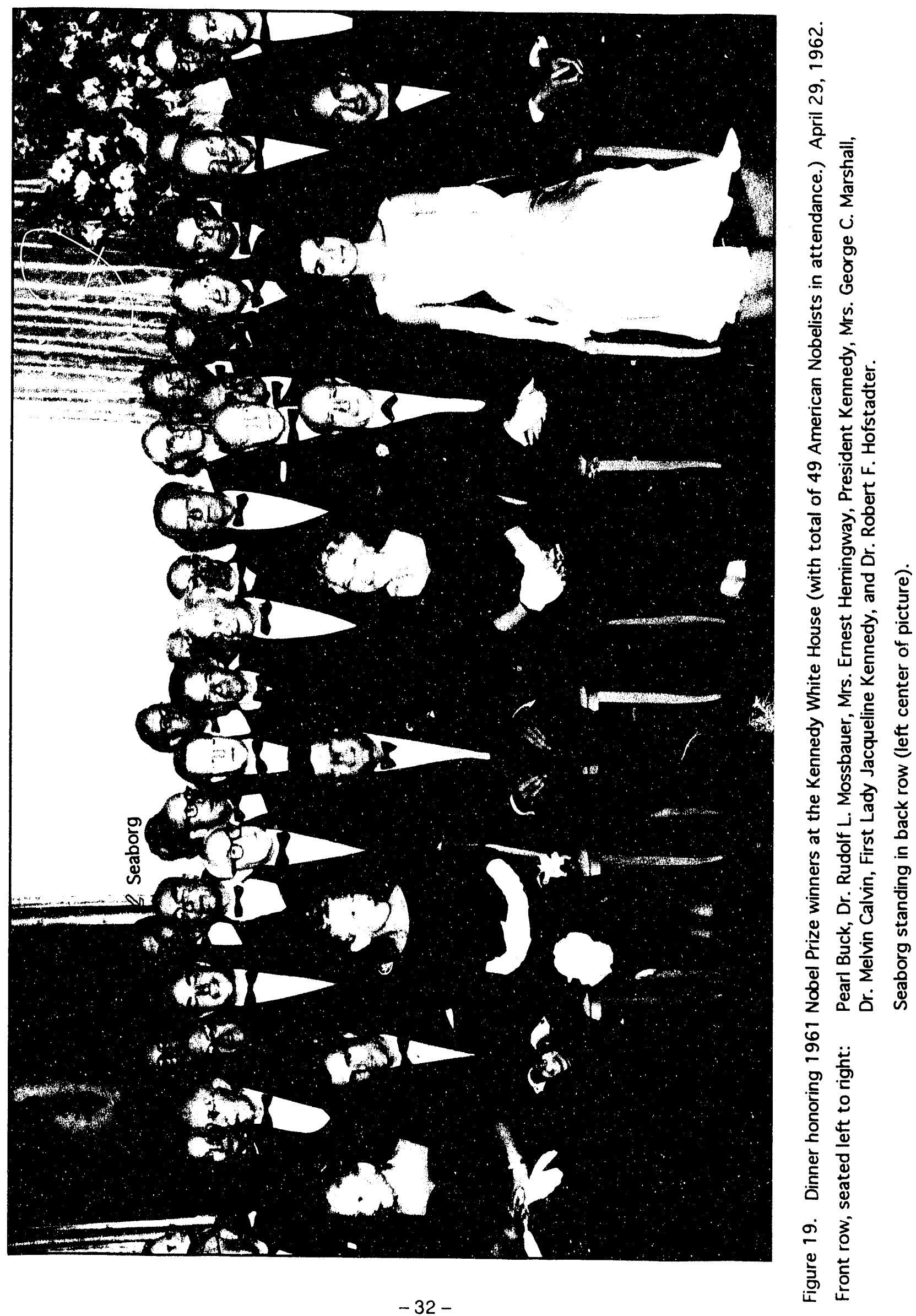


taking off, he asked that a low-level flight be made around the crater and this was done. Quoting from my journal of December 7, and December 8, 1962:

"Friday, December Z, 1962

I accompanied President Kennedy on his tour of AEC and AF installations. We left Andrews Air Force Base at 8:30 a.m. in the presidential plane. Others on board were: Ros Gilpatric, Secretary Eugene Zuckert, General Curtis E. LeMay, Admiral George W. Anderson, General Earle G. Wheeler,

General David M. Shoup, Jerry Wiesner, Harold Brown, Spurgeon Keeny, Don Hornig, Mac Bundy, Pierre Salinger, Mrs. Evelyn Lincoln, Major General Chester V. Clifton, Brigadier General Godfrey T. McHugh, Captain Tazewell Shepard, Kenneth O'Donnell and Dr. George Burkley (the President's physician).

We arrived at Offutt Air Force Base in Omaha about 10 a.m. where we visited $S A C$ headquarters and heard briefings on operations, the latest intelligence on Russian missile and AICBM sites, etc.

Vice President Johnson and party (including Fritsch) followed us in another big 707 jet.

At 1 p.m. our group, minus most of the DOD people but including Fritsch, [Vice President Johnson,] and General Wheeler, flew to Santa Fe (arriving at 2:15 p.m.) where a huge crowd greeted the President. After being joined by Senator Anderson we flew to Los Alamos, with the President, Senator Anderson, O'Donnell, Shepard and me in the front compartment and Wiesner, Bundy, Salinger and Secret Service men in the rear compartment. We were met by a huge crowd at Los Alamos.

We then continued by helicopter to the Los Alamos Scientific Laboratory and landed at the Chemical and Metallurgical Research Building. Schreiber, Bradbury, Finger and I briefed the President on the ROVER program with the aid of models...

The President and entourage, including New Mexico Congressmen Joseph Montoya and Thomas Morris, who had joined us when we landed at Los Alamos, then drove in a motorcade to the football stadium, where the President gave a marvelous impromptu speech. The motorcade then proceeded to the airstrip.

I flew with President Kennedy and Senator Anderson in the front compartment of the helicopter to Albuquerque (Kirkland Airport). There the President received another big reception. We proceeded by motorcade. to Sandia Corporation. Kenner Hertford (Area Manager, ALOO) and Monk Schwartz (President, Sandia Corporation) briefed the President on nuclear weapons and command and control with sample of weapons, old and new, and much of the component parts.... 


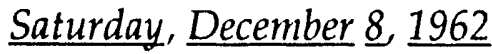

We flew in the presidential plane to Indian Springs Air Force Base. We left Albuquerque at 9 a.m. and arrived at 9:15 a.m. I flew in the front compartment of a helicopter with President Kennedy, Al Graves, Senators Howard Cannon and Alan Bible (who flew with us in the plane from Aibuquerque) over the Nevada Test Site.

We flew over the spot that is planned for a community, the site of SMALL BOY (a July effects test), LASL and LRL underground test sites, the SEDAN crater (which the President requested that we circle), and $L R L$ testing tunnels. We landed at the Nuclear Rocket Development Site (NRDS) where Finger and I escorted the President through the Maintenance and Disassembly Building (MAD). I then rode in an open car with the President for a tour of NRDS. (Figure 20.) We ended up at Engine Test Site (ETS) \#l where, with the help of Erickson (of Aerojet General), we showed the President the huge stand for testing the NERVA engine (22 ft. by $40 \mathrm{ft}$.).

Reporters and photographers (some 40 or 50) met us at the MAD building and ETS and at points in between to take numerous pictures and movies of the President with Finger and me.

I had a chance to discuss many things with the President during the helicopter trip and the ride in the open car-the ROVER schedule, the civilian nuclear power program, PLOWSHARE excavation potential, basic research leading to the discovery of fission and

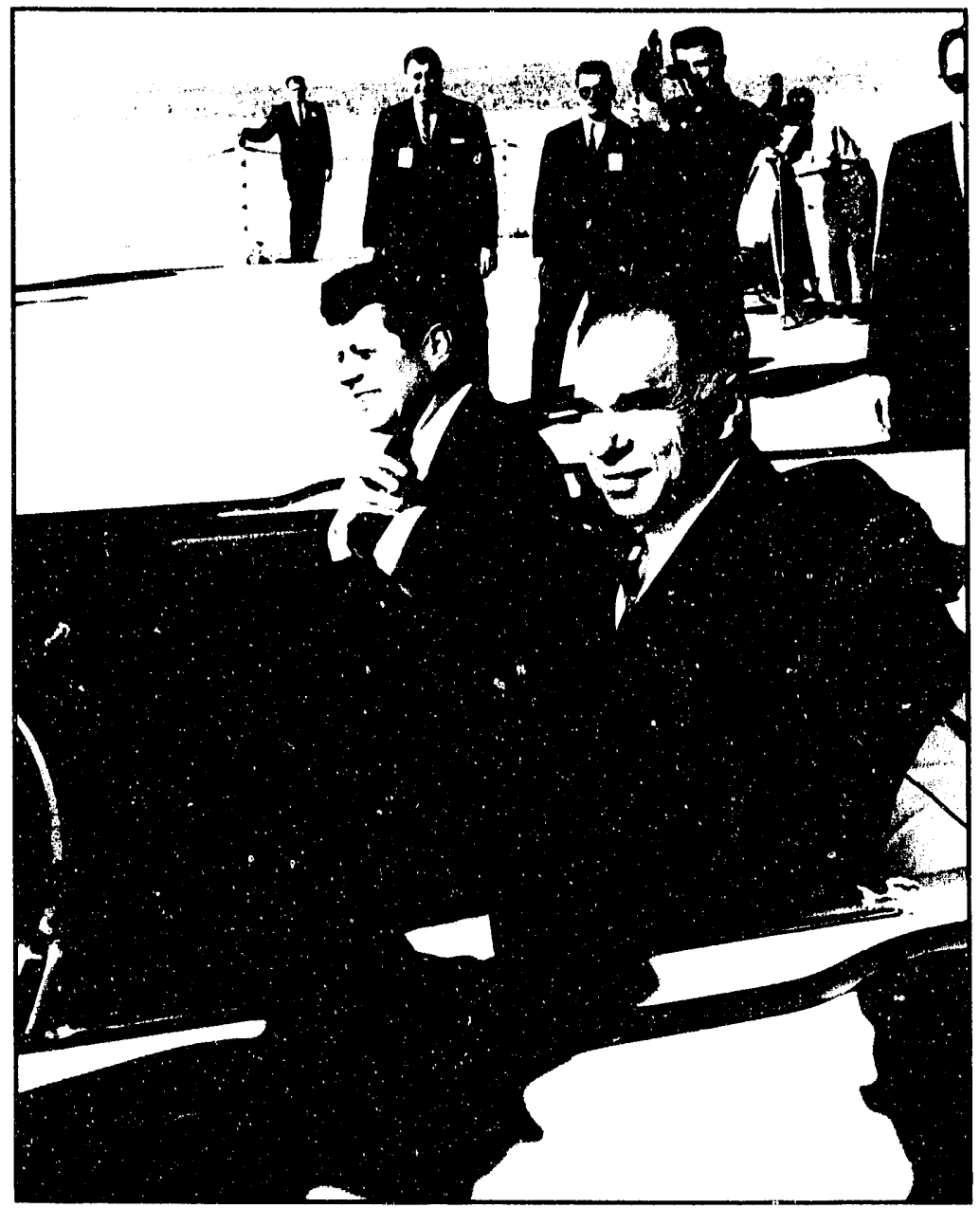

Figure 20. Kennedy and Seaborg touring the Nevada Test Site in an open car, December 8, 1962. 
plutonium, the need for a community near NRDS, the PLUTO project, SN/AP-50 and the \$25 million start he gave it, the 10,000 MW nuclear desalination project and many other items."

In May, 1963, I led a ten-man delegation to the Soviet Union for a tour of nuclear facilities. (Figure 21.) The president made Air Force One available to our delegation, and we arrived in Moscow on May 19, after a record-breaking eight hours and 39 minutes non-stop flight from Washington, D.C. Our tour of facilities, some not shown before to Western scientists, and the cordial treatment we received, helped to affirm my belief that science can successfully serve as a common meeting ground and a common language between the East and West. I met and had a long talk, at this time, with Soviet President Leonid I. Brezhnev. I believe that my visit played a role in setting the stage for the successful negotiations that led to an agreement on the Limited Test Ban Treaty during Averell Harriman's "Twelve Days in Moscow" some two months later.

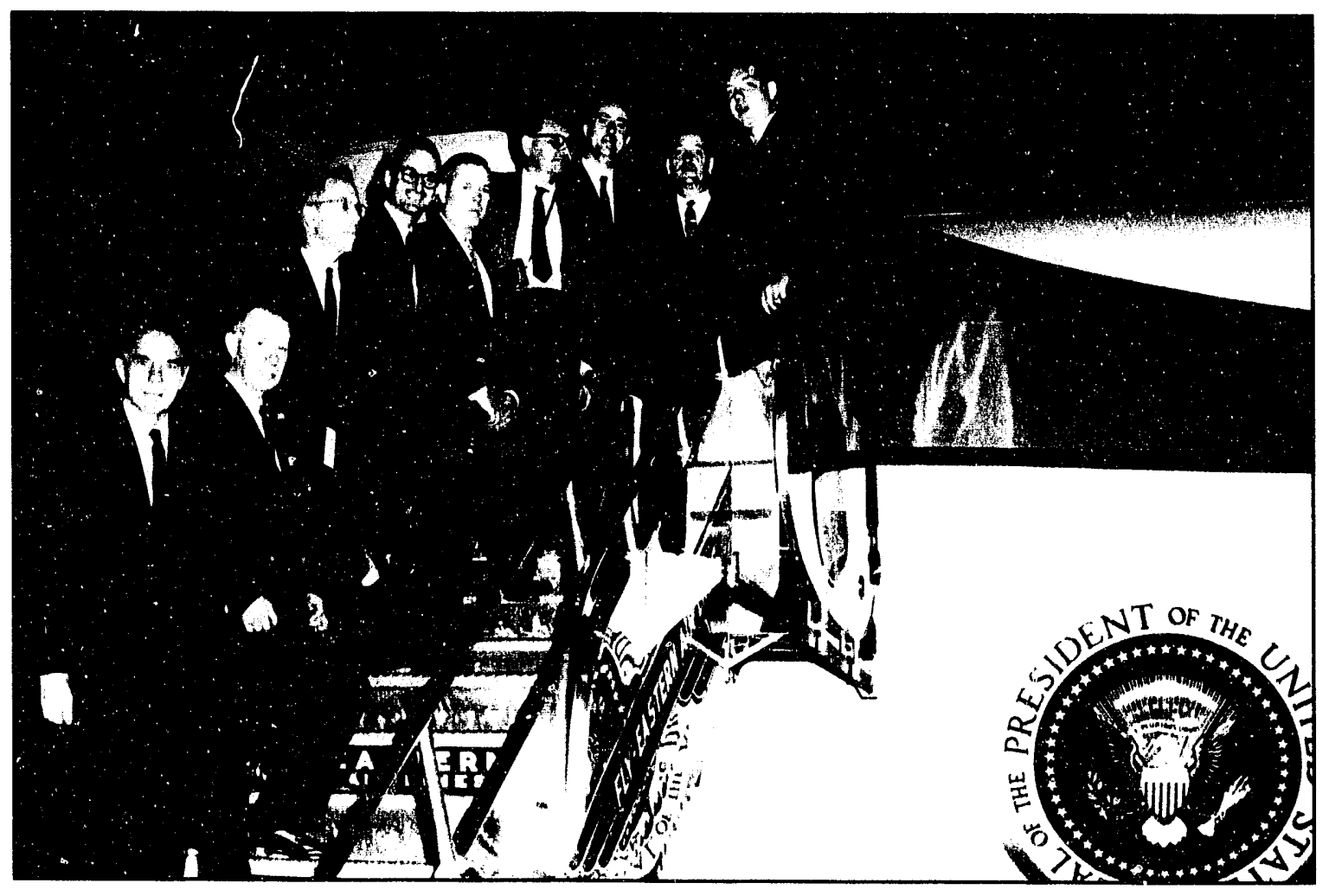

Figure 21. U.S. delegation boarding Air Force One to Moscow, May 18, 1963.

Left to right: Seaborg, Alvin Luedecke, Manson Benedict, Alexander Zucker, Gerald Tape, Albert Ghiorso, Albert Crewe, Cecil King, and Arnold Fritsch. (Algie Wells not present.)

In August, 1963, I flew on Air Force One with Secretary of State Dean Rusk and his delegation to be present in Moscow on August 5 for the signing of the Limited Test Ban Treaty. This historic signing (by Dean Rusk, Soviet Foreign Minister Andrei Gromyko, and British Foreign Secretary Lord Home) took place at 4:30 p.m. in the Kremlin in Catherine's Hall. A meeting with Premier Nikita 
Khrushchev in his office that morning preceded the signing and a reception in the Georgian Hall followed the signing ceremony:

"From 11 a.m. to 12 noon the U.S. delegation visited Nikita Khrushchev in his Kremlin office, which is long and narrow. We sat at a table with a green felt top, like a pool table. There were windows on the west side, pictures of Lenin and Marx, an electric clock on Khrushchev's desk, bookcases, and two telephones at the conference table. (I saw only one telephone at Khrushchev's desk.) Gromyko, Kuznetsov, Smirnovsky, and Dobrynin were present. After greetings by Khrushchev and Rusk, Khrushchev said the Test Ban Treaty was only a first step and that the main problem is the German problem. He said liquidation of the Government of the German Democratic Peoples' Republic would not be a victory for the United States, nor would a Communist win (i.e., liquidation of the Federal Republic) be a victory for the Soviets, and that a common solution was needed. Rusk recognized that the German solution is fundamental, and he will discuss it with members of the Soviet Government. Rusk said we understand the historical reasons why it is important to the Soviet Union--we, too, went through two World Wars-but the German people need an opportunity for peace so as not to give them reason to start trouble again. There has been a relaxation of tensions in East Europe in the last year.

Khrushchev observed that Rusk doesn't use the term Socialist country but says "the East." Rusk said that "some people in the United States call us Socialist." Khrushchev said "such a man to say that." Rusk said that the Yugoslav Government is less involved in its country's economy than the U.S. Government is in the American economy. Khrushchev said, "capitalism gave birth to communism, let's compete in culture instead of rockets." Rusk said that Glenn Seaborg, Stewart Udall and Orville Freeman have visited the Soviet Union and advancement of relations continues; let's cooperate in the peaceful uses of atomic energy, education, etc.

Rusk then called on Senator Fulbright, as Chairman of the Senate Foreign Relations Committee. Fulbright recalled Khrushchev's pleasant meeting with his Committee four years ago. He referred to U.S. internal trouble of 100 years ago, which has been overcome and now the South gets along with "the damn Yankees." Similarly the United States and the Soviets can get along. The United States is capitalistic, but actually, a mixed economy. Someone has said the Soviet Union is promoting capitalism. Also, the U.S. Democratic Party has been accused of promoting socialism. The differences are less than we think. He recalled that someone said Khrushchev would be a good member of Congress and that Khrushchev replied, "You don't get to be Chairman of the USSR Council of Ministers by being stupid." Khrushchev agreed on our common goals.

Khrushchev said, "You (U.S.) go forward on private property; we (USSR) on common property. We are for everyone; you are for "every man for himself.'" Udall paid eulogy to the USSR achievement in power 
plants. "The Soviet Union will solve problems in agriculture drastically in seven years, and completely by the 1980's." Khrushchev said they are putting billions of rubles into chemical industry, agriculture, etc. He showed a sample of some plastics and a plastic cup. Khrushchev invited Rusk to come down to the Black Sea for a dip because his vacation begins tomorrow; whereupon Gromyko said Rusk shouldn't swim toward Turkey. On the way out of his office I talked to Khrushchev and he referred to me as "my old friend."

The U.S. delegution then toured the Kremlin Arms Chamber Museum and rooms in the large Kremlin Palace. We had lunch in the oldest room of the Kremlin (built 500 years ago), at a large U-shaped table with about 100 guests. Khrushchev, Rusk, Home and U Thant spoke--all along lines of a test ban as a symbolic step. We retired to on anteroom for coffee and brandy. At lunch I sat next to Ilychev (Secretary for Ideology of the Central Committee, an historian and speech writer) and Ya. V. Peive (Chairman, Council of Nationalities of the Supreme Soviet, a biochemist from Riga), and near Petrosyants and K. N. Rudnev (Deputy Chairman, Council of Ministers, and Chairman, State Committee for Coordination of Scientific Research Work, a mechanical engineer).

At 4:30 p.m. we attended the historic signing (Figure 22.) of the Limited Nuclear Test Ban Treaty, in Catherine's Hall, by Rusk, Gromyko and Home simultaneously, followed by speeches by Gromyko, Rusk, Home and U Thant. I stood just behind Khrushchev and he and I tipped our champagne glasses together for toasts at least five times. About 50-60 press representatives and photographers were present.

At about 5:15 p.m. we attended a huge reception in Georgian Hall (magnificent!) where Khrushchev pulled a prepared speech ou. of his pocket, and delivered it. I took a picture of him with my Minox camera (which was perhaps a risky endeavor). (Figure 23.) I had a chance to talk to Brezhnev, Petrosyants, Gromyko, Kuznetsov, Dobrynin, Zorin, Tsarapkin, and Voroshilov (of the military).

That evening I went to the circus and walked through Gorky Park with Senator Pastore.

A glorious day."

I have described in my book, Kennedy, Khrushchev, and the Test Ban (written with my colleague Benjamin S. Loeb), Kennedy's central role in the achievement of the Limited Test Ban Treaty. (Visits to the John F. Kennedy Library, in Boston, Massachusetts, were helpful in the writing of the book.) On April 11, 1988, accompanied by Helen, I participated, along with numerous other members of the Kennedy Administration, in the commemoration (which was videotaped) of the 25th anniversary of the Limited Test Ban Treaty at the John F. Kennedy Library in Boston. 

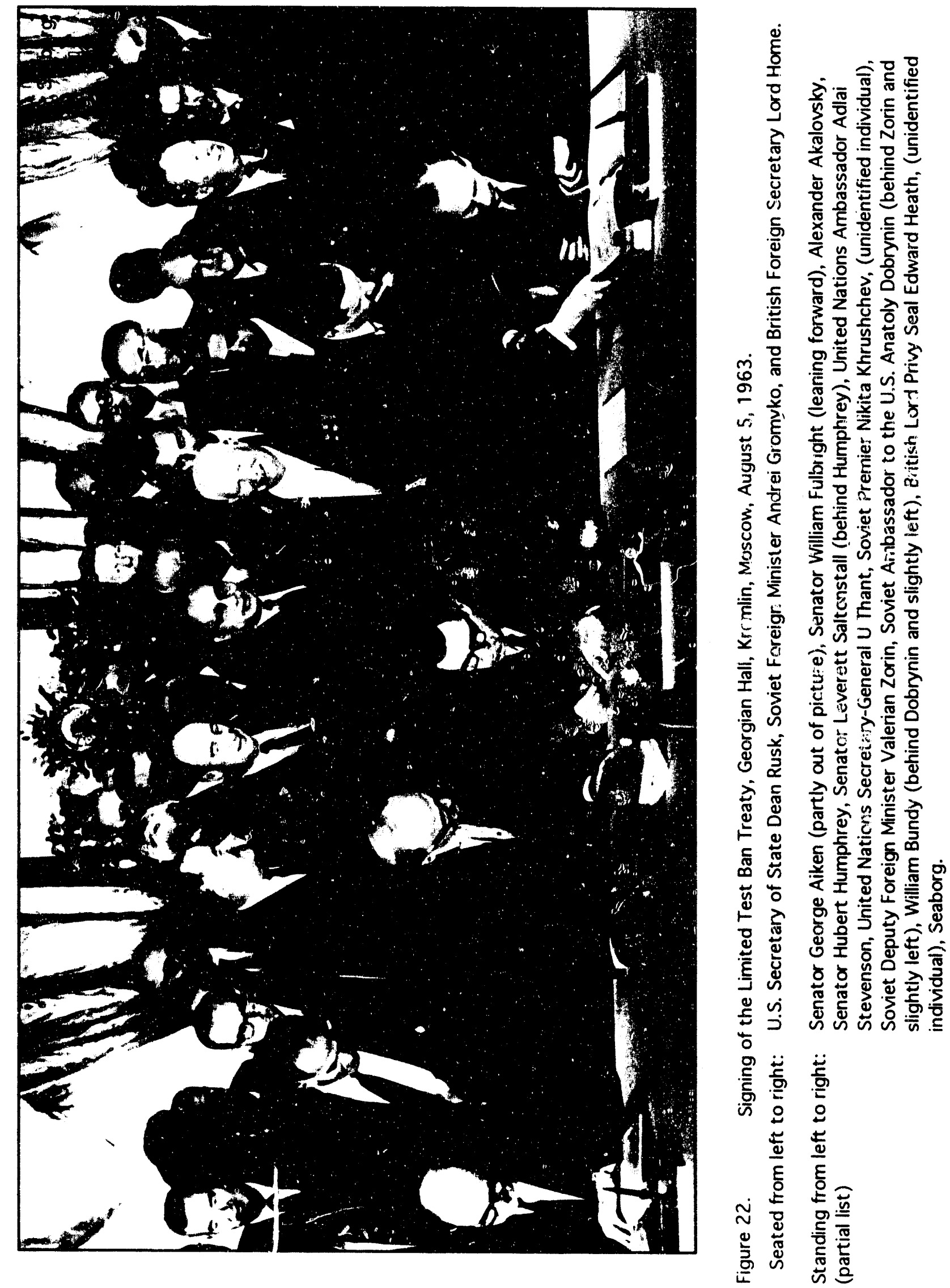


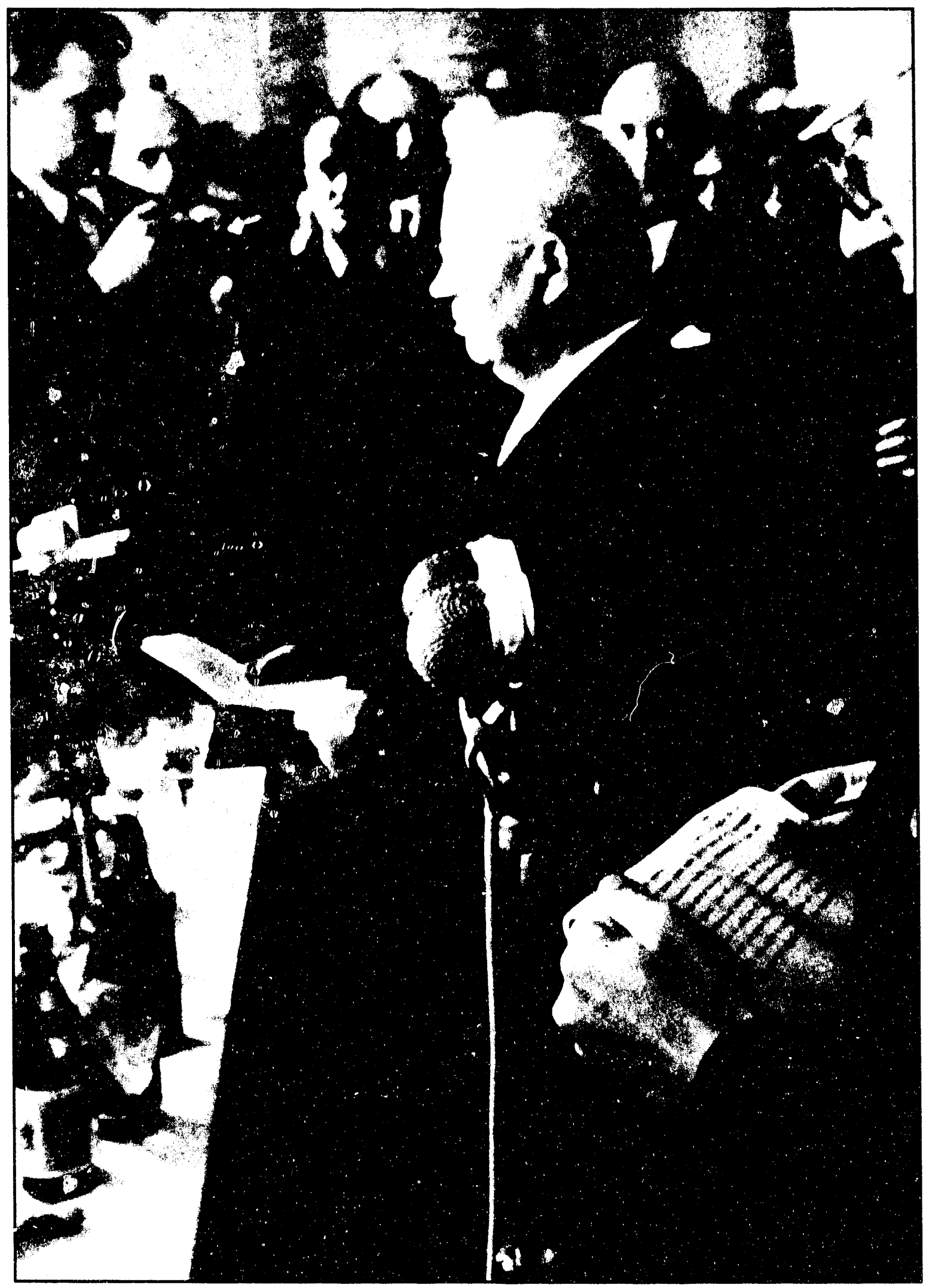

Figure 23. Soviet Premier Khrushchev delivering speech at reception after signing of the Limited Test Bani Treaty, Georgiani Hall, August 5, 1363. (Photo taken by Seaborg with his Minox camera.) 
One day in June,

1963, I received a

telegram at home from

President Kennedy

expressing delight that I

had consented to

re-appointment as

Chairman of the Atomic

Energy Commission.

This was later confirmed by a letter on June 27 , 1963. (Figure 24.)

Although I couldn't remember ever

discussing this with him, it seemed to me that I couldn't turn down the President of the United States, so I accepted the re-appointment.

As I have indicated, I accompanied Kennedy or a remarkable number of visits to $\mathrm{AEC}$ installations--the AEC headquarters at Germantown, Maryland; the Radiation Laboratory at Berkeley; the Los

Alamos Laboratory and the Sandia Laboratory in New Mexico; and the Nuclear Weapons Test Site in Nevada. He also visited the Hanford Plant in Washington, accompanied by Commissioner Gerald Tape on September 26, 1963 (while I was in Europe attending the IAEA General Conference). Even before he became president, while he was a U.S. Senator from Massachusetts, he and his wife Jacqueline visited the Oak Ridge National Laboratory. (Figure 25.)

I last saw President Kennedy on a question concerning the production of fissionable materials. The day was November 8, 1963. At that time, he was, as always, cordial and attentive, and quickly grasped the problem. He displayed his usual quick wit and friendly humor.

There was a tragic irony in the circumstances in which the news of President Kennedy's assassination reached me. As on January 9, 1961, when he called to invite me to assume the position as Chairman of the Atomic Energy Commission, again, I was in the Lawrence Radiation Laboratory of the University of California, and again, I was in the HILAC Building, this time, 


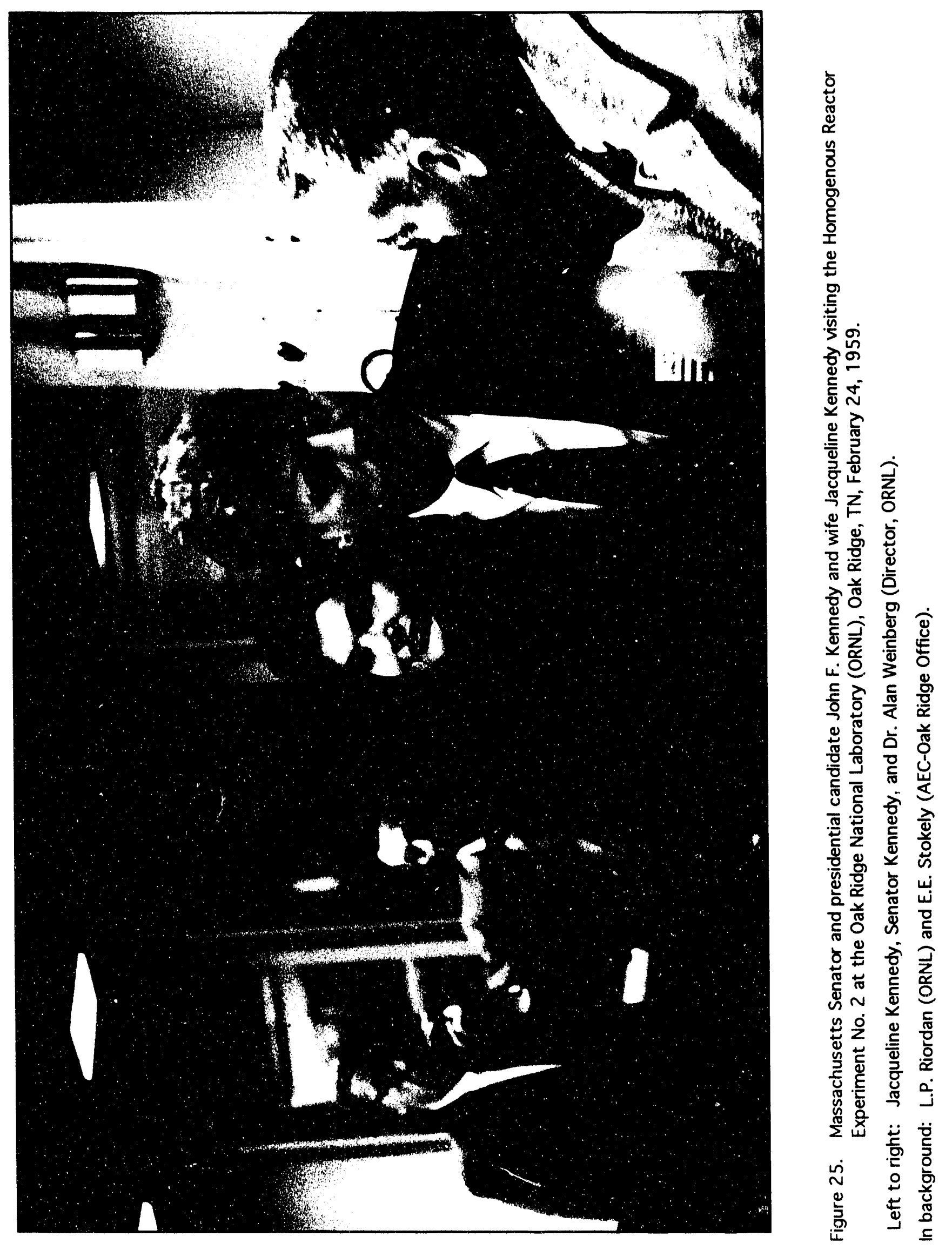


participating in the reciprocal visit of Soviet scientists. I was called aside, because of some very important news. I stepped away and was told that the president and Texas Governor John Connally had been shot.

I was devastated to learn of the death of this vital and vibrant young man, John Kennedy, who had brought such a new air of optimism to Washington with his exciting "New Frontier." He had an almost unique appreciation and understanding of the important role of science and scientists in modern society. I particularly appreciated his complete dedication to the attainment of a treaty to end the testing of nuclear weapons. Some 16 years later, on October 20, 1979, I was pleased to attend the dedication ceremony for the John F. Kennedy Library in Boston, Massachusetts (as described in Section 8.)

\section{Lyndon Baines Johnson}

The presidency of Lyndon B. Johnson is perhaps remembered chiefly for his extraordinarily successful promotion of his concept of The Great Society and, unfortunately, his role as a leader in the Vietnam War. As Chairman of the Atomic Energy Commission, I didn't play any important role in the achievement of the former, but I did watch (as a result of my attendance at numerous meetings) with awe and admiration, his complete dedication to and success in initiating this ambitious social program. I was also in a position to see how the over-optimistic advice and urgings of his military advisors led inevitably to our ensnarement into the Vietnam War. I recall that I was visiting the San Francisco Bay Area with my administrative assistant, Arnold Fritsch, when we saw and heard on March 31, 1968, the televised speech by President Johnson, in which he announced the de-escalation of the Vietnam War and the cessation of bombing on North Vietnam, and, surprisingly, his decision not to seek or accept the Democratic nomination for president.

I have recounted in detail in my book, Stemming the Tide-Arms Control in the Johnson Years (written with my colleague Benjamin S. Loeb), Johnson's important role in the final achievement of the Nonproliferation Treaty. (Visits to the Lyndon B. Johnson Library in Austin, Texas, were helpful for the writing of this book.) Success came only as he turned his attention seriously to the attainment of this objective. He also was well on the road toward the achievement of the SALT treaty when he was thwarted in this objective by the untimely Soviet invasion of Czechoslovakia. 
Johnson had perhaps the strongest and most overwhelming personality of any person that I have ever known. His ability to bring key members of Congress around to his way of thinking and to support of his legislative program was something to behold. I watched in amazement as he pursued his successful methods of persuasion. My wife Helen characterized his presence, on the basis of her personal experience, as literally "surrounding" the person to whom he was talking. (Figure 26.) However, during such conversations, Helen also felt that he had a genuine interest in her activities.

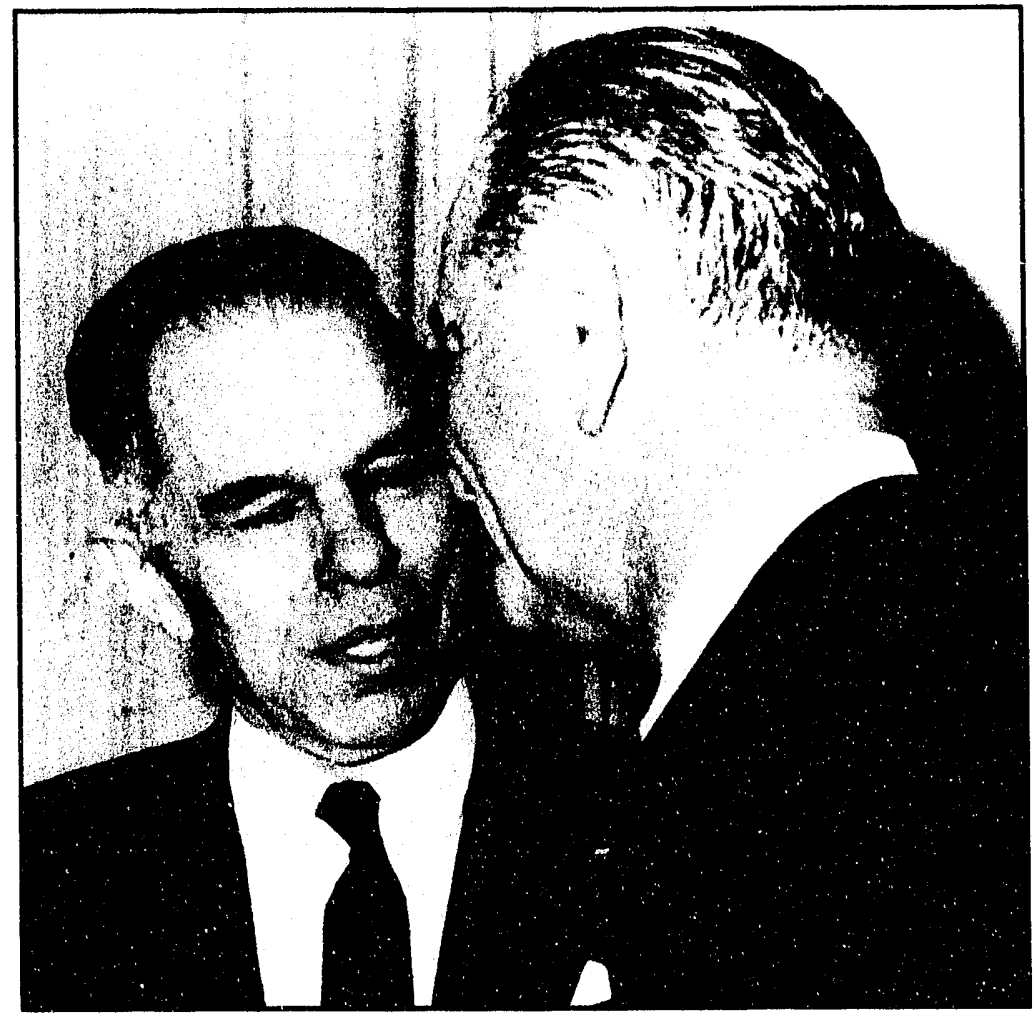

Figure 26. Seaborg getting the word from President Lyndon B. Johnson, White House, January 14, 1965.

When Johnson wanted information or advice, he wanted it right away. For this reason, one had to be prepared to present the full story on the spot. If you did not manage to make all your points the first time around, it was unlikely that you would be allowed a second opportunity. I remember one time when I was swimming at the University Club after work, as was my custom at that time. The University Club is a men's club (or was, at that time), and so members generally swam in the nude. As I completed a lap, an excited pool attendant informed me that the President of the United States wished to speak with me on the phone. Dripping wet, I took the call and marshaled all of my arguments against a proposition which I did not support. I remember feeling rather foolish, debating an issue with the president in that pose; however, I knew that the president might not wait until I grabbed a towel to bolster my sense of dignity.

It has been said that Johnson tended to place people in two categories-those he liked and trusted, and those whom he did not. Clearly, on the basis of his relations with me, he placed me in the favorable category. (Figure 27.) $\mathrm{He}$ apparently was convinced that I was straightforward, without a hidden agenda, in my dealings with him.

As during the Kennedy Administration, I attended meetings of the Cabinet and the National Security Council whenever some item of interest to the AEC was discussed. An especially interesting and important meeting of the Cabinet took place on October 20,1964. (Figure 28.) The main topics of 


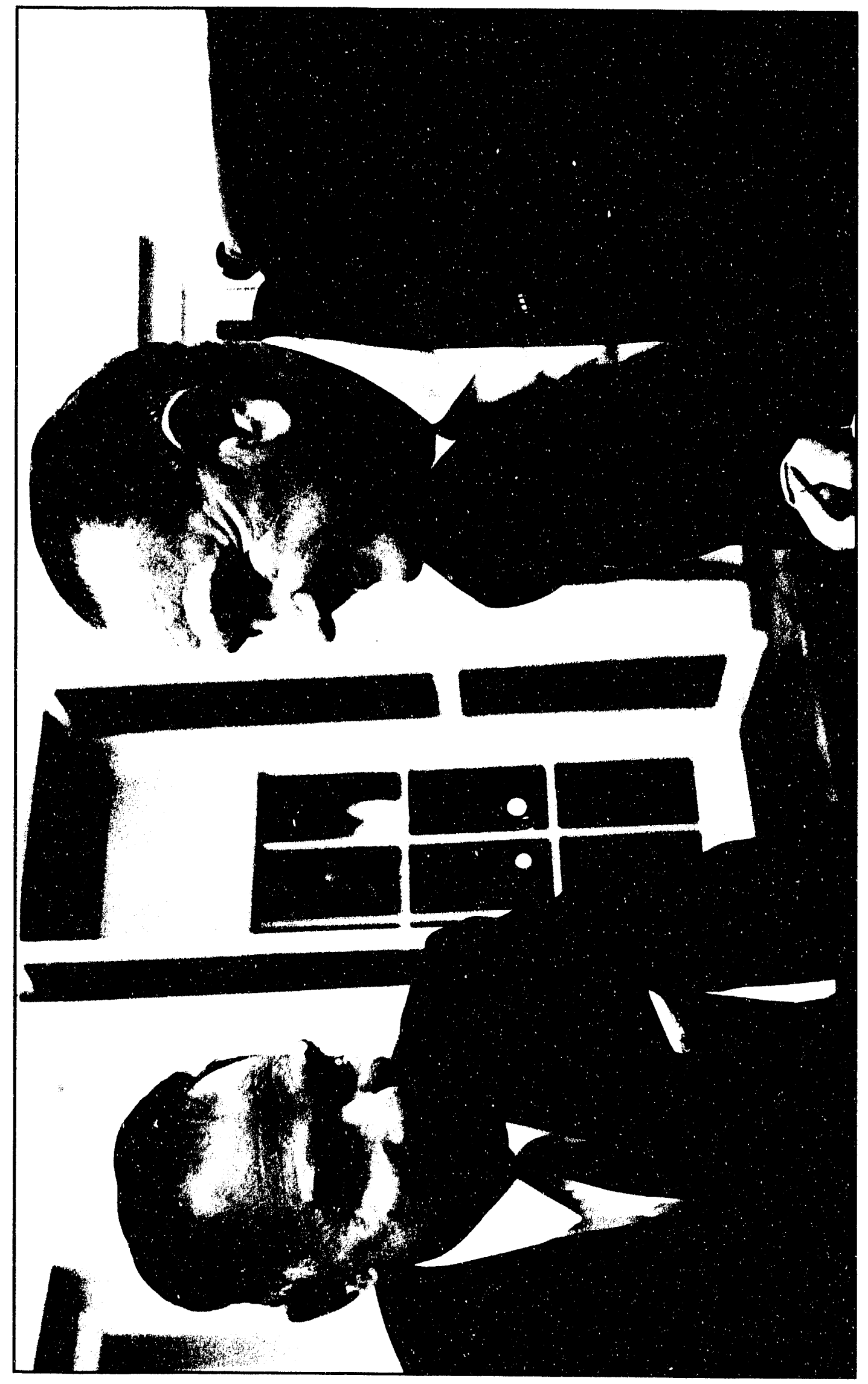

Oे 


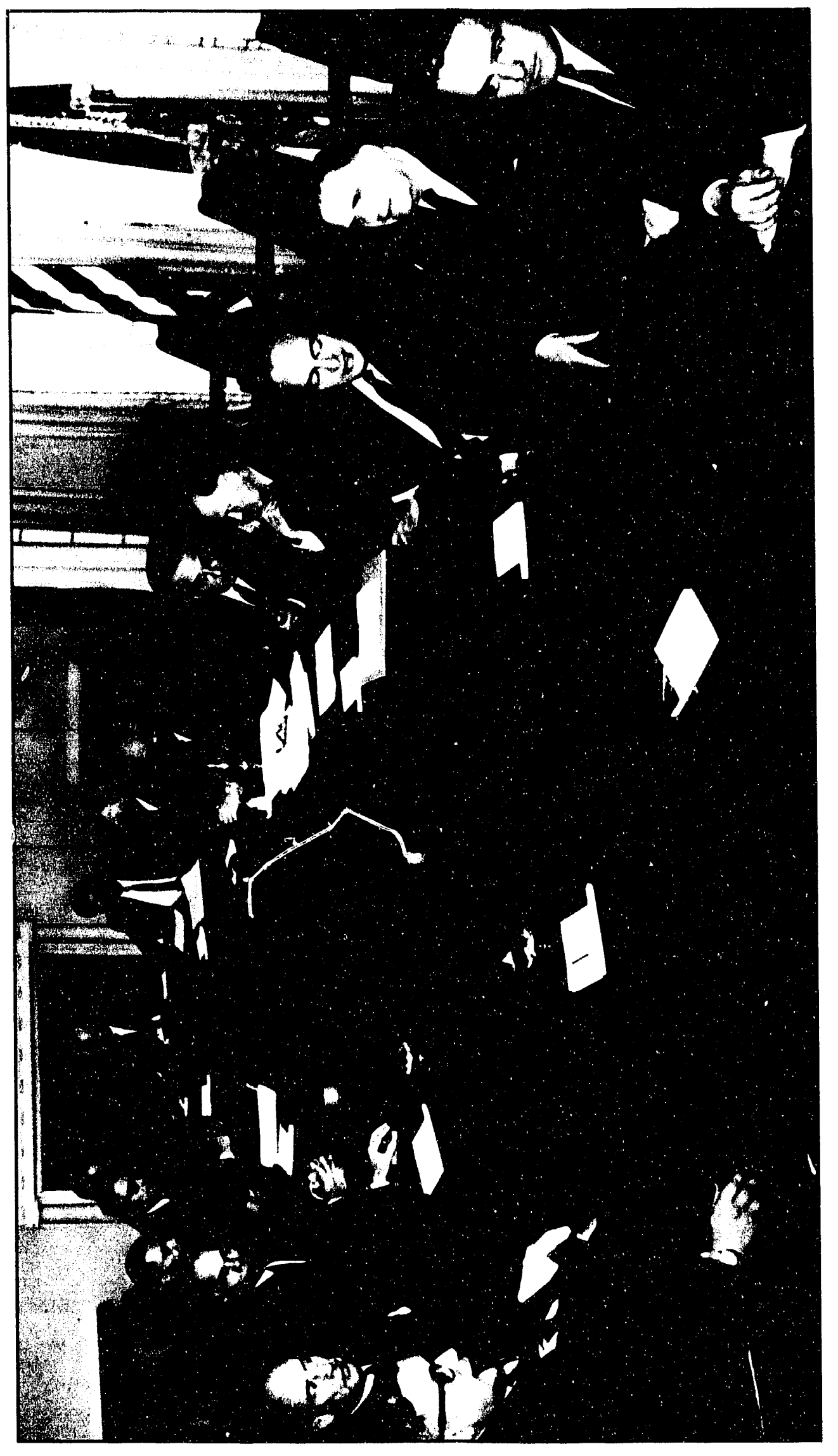

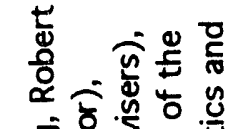

क人

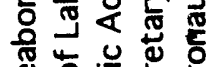

जे

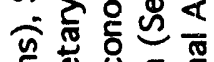

든

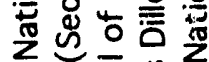

N

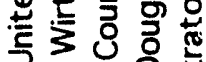

은

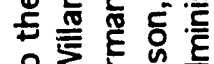

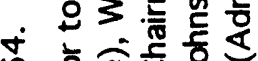

응 인응

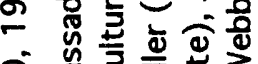

용

安要这的

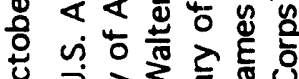

○ ट ख

ฆ

능 응

吕政前

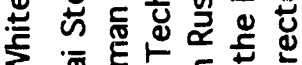

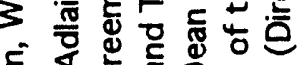

द्र

ชิ

屯

.

उु ब बे है

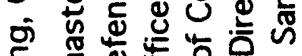

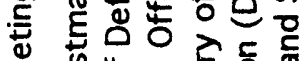

峞

ह 口

む

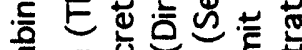

đ广

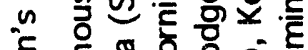

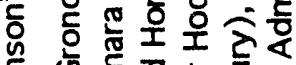

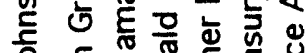

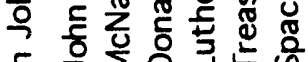

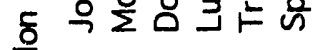

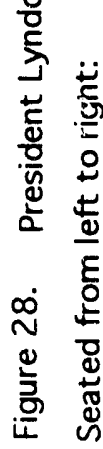


discussion were three unsettling events that had taken place at distant places during the preceding few days. These were the first nuclear weapons test in the Peof's's Republic of China; the unexpected ouster of Soviet Chairman Nikita Kivushchev who was replaced by Leonid I. Brezhnev (and A.N. Kosygin); and the electoral loss of the incumbent Conservatives in Great Britain to the Labour party led by Harold Wilson (thought to be less friendly to U.S. policy).

Johnson himself was not one to worry much about appearances. In fact, he cultivated his folksy image and was in his element at his ranch. Both LBJ and Lady Bird took obvious pleasure in showing guests their ranch in Texas, and on one occasion, Johnson presented Bureau of the Budget (BOB) Director Charles Schultze and me with the challenge of continuing the debate on major items in the AEC budget while he drove us around the ranch in his white Chrysler station wagon. In addition to other guests, passengers in the car included his six-yearold grandson Patrick Nugent and his dog Yuki, who both competed with us for his attention.

LBJ was very proud of his ranch, particularly of his collection of wild animals. On tours of the ranch, I saw lots of deer, including the native whitetailed Texas deer, English deer, Japanese deer, Axis deer, nilgai (a species of Cambodian antelope), and other antelope. On one tour, the president stopped his car, got out, and with considerable difficulty, chased some quail, back into an enclosure from which they had escaped. I commented that this was probably "as high-priced help as had ever chased quail"--which seemed to tickle him no end.

My meetings with President Johnson, at the LBJ Ranch in Texas in December of each year, to debate with the Director of the Bureau of the Budget disputed items in the AEC budget were uniformly successful. Following are some excerpts from my journal for Friday, December 10, 1965:

"I flew to Texas on a Jet Star, leaving National Airport at 7:30 a.m., with Commerce Secretary John Connor, Jim Webb, Don Hornig, Mr. and Mrs. Arthur Krim, General Green (Commandant of the Marine Corps), and General H. K. Johnson (Chief of Staff of the Army). We arrived at the LBJ Ranch landing strip about 10 a.m. and were met by President and Mrs. Johnson. The President drove some of the group in one car and Mrs. Johnson drove another part of the group, including me and Jim Webb, in another car to the Ranch itself, which is just a few hundred yards from the landing strip. The President then went into a meeting with the Joint Chiefs of Staff, Secretary McNamara and Deputy Secretary Vance to discuss budget matters and decisions concerning the Department of Defense...

...Later in the afternoon, after the President had seen Jim Webb and before he had seen Secretary John Connor and Agriculture Secretary Orville Freeman, I met with the President, along with BOB Director Charles Schultze, Don Hornig and Joe Califano to discuss the AEC budget issues.... 
... We then discussed the four so-called " $A$ " items at issue in the FY 67 budget. The first item was the BOB suggestion that one of the ten presently operating plutonium production reactors be closed down. I resisted this strongly, emphasizing that a study is under way for the whole requirements picture, that this will be due in May, and that it would be unfortunate to prejudge the outcome of this. I pointed out the nonweapons needs for reactor products, such as radioisotopes, and emphasized the need for isotopes like Pu-238 to power an artificial heart. This seemed to impress the President, despite the fact, as pointed out by Hornig, that the cost of such a power source would be about $\$ 10,000$ for each artificial heart. However, the President pointed out that such a cost would not be prohibitive and that the project might be worthwhile even if only one such artificial heart were available. I also mentioned the need for continued high neutron flux reactor operation and our suggestion that we should stockpile tritium. I also mentioned the political problems with the JCAE and other congressional committees attendant with shutting down another reactor. The President ruled in my favor, and said that we shouldn't shut down a reactor.

The second " $A$ " item issue involved the $B O B$ recommendation that $\$ 4$ million be cut from the weapons research and development budget, which would mean that it would be necessary to reduce rather substantially the personnel in the weapons laboratories. I made the argument that this would be contrary to the safeguards which had been endorsed by the President, and that it would have a great adverse effect on the morale of the laboratory people and on the ability of the laboratories to recruit. The President ruled in my favor that this cut should not be made.

We then discussed the item of $\$ 4$ million for AEE on the $200 \mathrm{BeV}$ Accelerator. I pointed out the need to have such a line item in the budget in order to be consistent with our actions to date, and to assure the scientific community that we are serious and to keep the design scientists on the job. Schultze pointed out the high cost of building the accelerator and the high operating cost. He pointed out that the construction cost would be $\$ 308$ millici:, and by the time you add equipment needed at the accelerator site and at the universities for the users groups, the total cost would be about $\$ 400$ million. He also pointed out that the operating cost would be about $\$ 60$ million per year at the site and by the time you add the operating costs for the users at the universities, this would amount to $\$ 90-\$ 100$ million per year. He said he wanted to emphasize the tremendous cost that any commitment to build would entail. I described the status of the process for selecting the site for the $200 \mathrm{BeV}$ Accelerator and mentioned some of the beneficial side effects of this site selection process, such as the awakening of various parts of the country to the value of educational institutions, scientific research and cultural activities. I said that some universities had obtained from their state legislatures money earmarked for research for the first time, as a result of the competition for the $200 \mathrm{BeV}$ Accelerator. I also mentioned the time scale for the selection. The President ruled in favor of including the $A \mathcal{E} E$ money, but with the understanding that there would be no commitment at this time for building this very expensive facility. 
The final " $A$ " item was the $\$ 2.9$ million for research and development and the \$3 million for AEE for the Los Alamos Meson Physics Facility (LAMPF). Schultze pointed out that we do have in: the " $A$ " budget a $\$ 45$ million project to conver the AGS to higher intensities. He said that this AGS conversion, plus the $200 \mathrm{BeV}$ Accelerator, is a very expensive program, and he doubted that we could add LAMPF to it. I emphasized the great scientific need for this project. I said it is a matter of making up our mind ce way or the other, that is, either kill the project or add the requested funds to the budget, because the work has gone on in a state of indecision so long that it would not be possible to retain the scientists for another year without a decision. I also pointed out the strong support from Senator Clinton Anderson and the strong (essentially unanimous) support of the JCAE. The President said he would like to think about this further. (Just before I left the Ranch, at about 5 p.m., I learned that the President had decided to include this in the FY 67 budget.)

...During these discussions, the President sat in a reclining chair in a very relaxed fashion and at times had his eyes closed during the discussions. The room in which we met was rather dimly lit so that it was not possible to use the extensive backup material that I had brought along; however, this didn't turn out to be necessary because I had studied the material thoroughly the night before and earlier in the week and on the plane coming down to the Ranch. At one point during the course of the discussion I mentioned that I thought Secretary McNamara is making a mistake in not including nuclear power for an aircraft carrier and a frigate in his budget.

Connor, Freeman, Webb, Hornig, Califano and I then went by helicopter to Austin, landing at the Civic Center, and we went on to the mezzanine of the Driskill Hotel where we participated in a press conference conducted by Bill Moyers, speaking individually and answering questions. I spoke about the President's interest in the peaceful uses of atomic energy, particularly desalting, advanced reactors and breeders, and the use of radioisotopes in medicine, such as to power an artificial heart. One question put to me was about the time scale for choosing a site for the $200 \mathrm{BeV}$ Accelerator. I replied that the NAS Committee will give us their recommendations in a few weeks and the Commission will make the choice of a site no sooner that a few months after that."

On this occasion, I was able to "rescue" the $200 \mathrm{BeV}$ Accelerator and the Los Alamos Meson Facility, and similar success in December meetings in subsequent years made possible the successful construction of these important accelerators. Many other AEC projects, nearly all that I presented for review to President Johnson at these yearly December meetings at the LBJ ranch, were similarly approved. He rescued many smaller projects from the understandable money-saving efforts of the Bureau of Budget and supported the development of civilian nuclear power. (Figure 29.) In the overall budgetary process, however, he was very conscious of the need for prudence and had no qualms about the elimination of some projects from the scientific arena, such as the Midwest 
Universities Research Association (MURA) Accelerator, nor about the curtailment of unneeded production facilities. In the latter category when he assumed office in 1963, he was completely unafraid to cut back drastically on the production of fissionable material despite the anticipated vigorous opposition from powerful elements in the Congress.

As an example of our interactions, I recall a meeting (Figure 30.) I had with the president in the Oval Office, lasting nearly all afternoon (2:30 p.m. to 6 p.m. on June 27,1965). I had the impression that here was a man who suffered periods of lonesomeness in his position of exalted isolation and thus, longed to spend some time in conversation with a friend. The flavor of this meeting is captured in the following extract from my journal:

"The President had his lunch--a bowl of soup--during this conference, since his schedule in greeting astronauts McDivitt and White caused him to be running late. He also took numerous phone calls and placed a number of calls to people like McNamara, etc., during the conference. At the end of the appointment, the President asked me to stay on for the press conference that was to take place later in the afternoon. It was in the intervening period that I talked to Valenti and others at the White House about the President's visit to the Radiation Laboratory and about his request to me to help in the preparation of the San Francisco U.N. Speech. I participated in the press conference, sitting behind his desk with the President and the Vice President. At the press conference, the President read almost verbatim from the material furnished with my letter of June 16,1965, the sections on the IAEA safeguards system, on nonproliferation, the progress report on nuclear power, and the U.S.USSR exchanges in atomic energy. The press conference ran until almost 6 p.m."

(Actually, his visit to the University of California's Radiation Laboratory did not materialize.)

Such brainstorming sessions were not uncommon with LBJ. Fortified with root beer, he jumped rapidly from one idea to the next, never limiting his notion of what one had to contribute to a particular area of expertise, and always keenly attentive to the potential public relations impact.

Even though Johnson did not worry much about how he appeared to others, he was very concerned with the image projected by his administration. His well-known habit of turning off the lights in the Oval Office, as an economy measure, approached the point of idiosyncrasy. I remember when we received instructions to give up our chauffeur-driven Cadillacs and ride in smaller, less ostentatious cars like Chevys. In the midst of an important meeting, LBJ interrupted the conversation to glare at me and demand to know why I was still riding in a Cadillac. I hastened to assure him that he had been misinformed, that I had traded in my Cadillac as soon as I received his instructions, and was already modestly riding in a more compact car. 


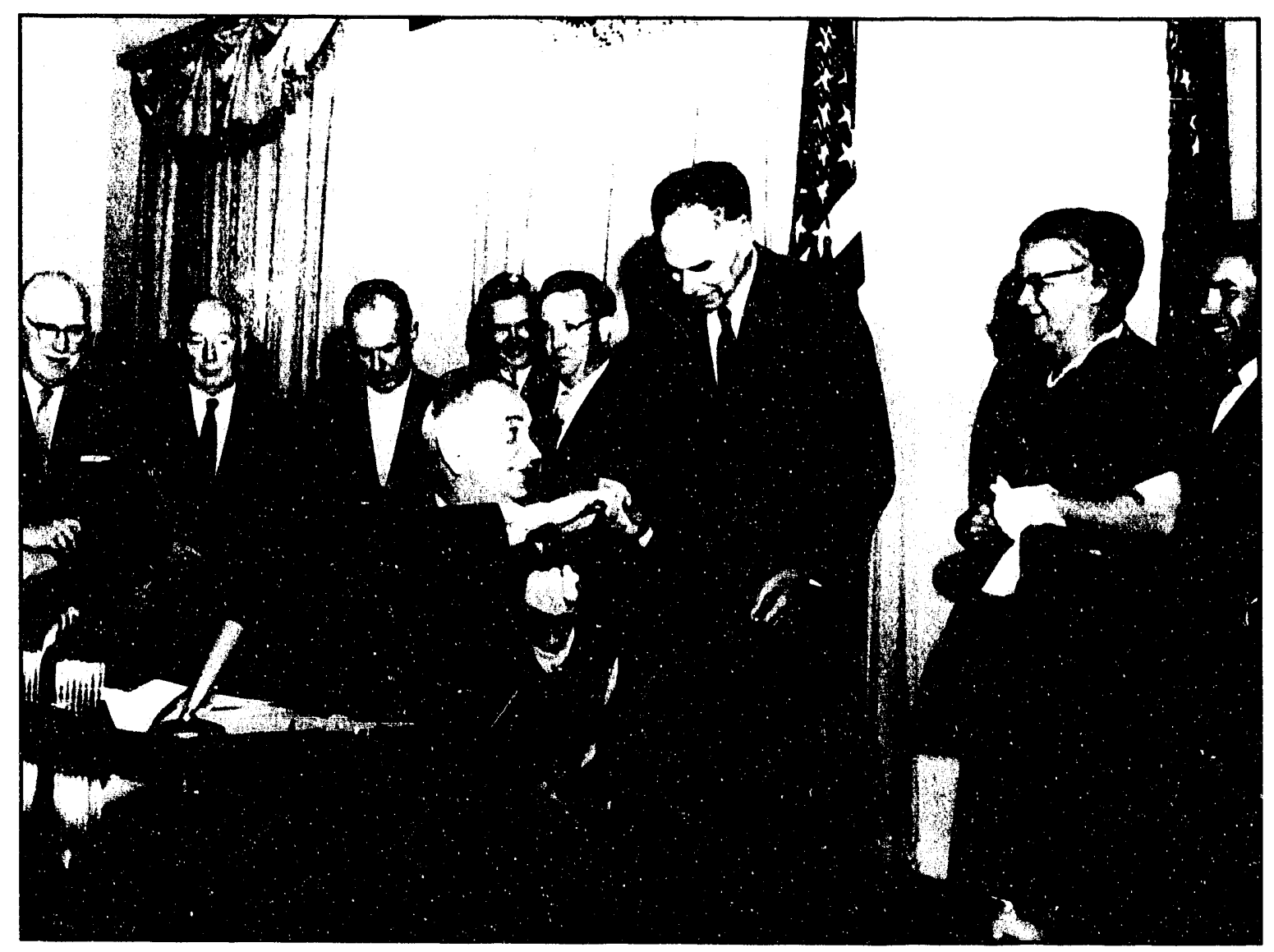

Figure 29. Johnson (seated) presenting pen to Seaborg at signing of the Private Ownership Bill, Cabinet Room, White House, August 26, 1964.

Figure 30.

(right)

"The exalted isolation of the presidency."

Seaborg meeting with Johnson in the Oval Office, June 17, 1965.

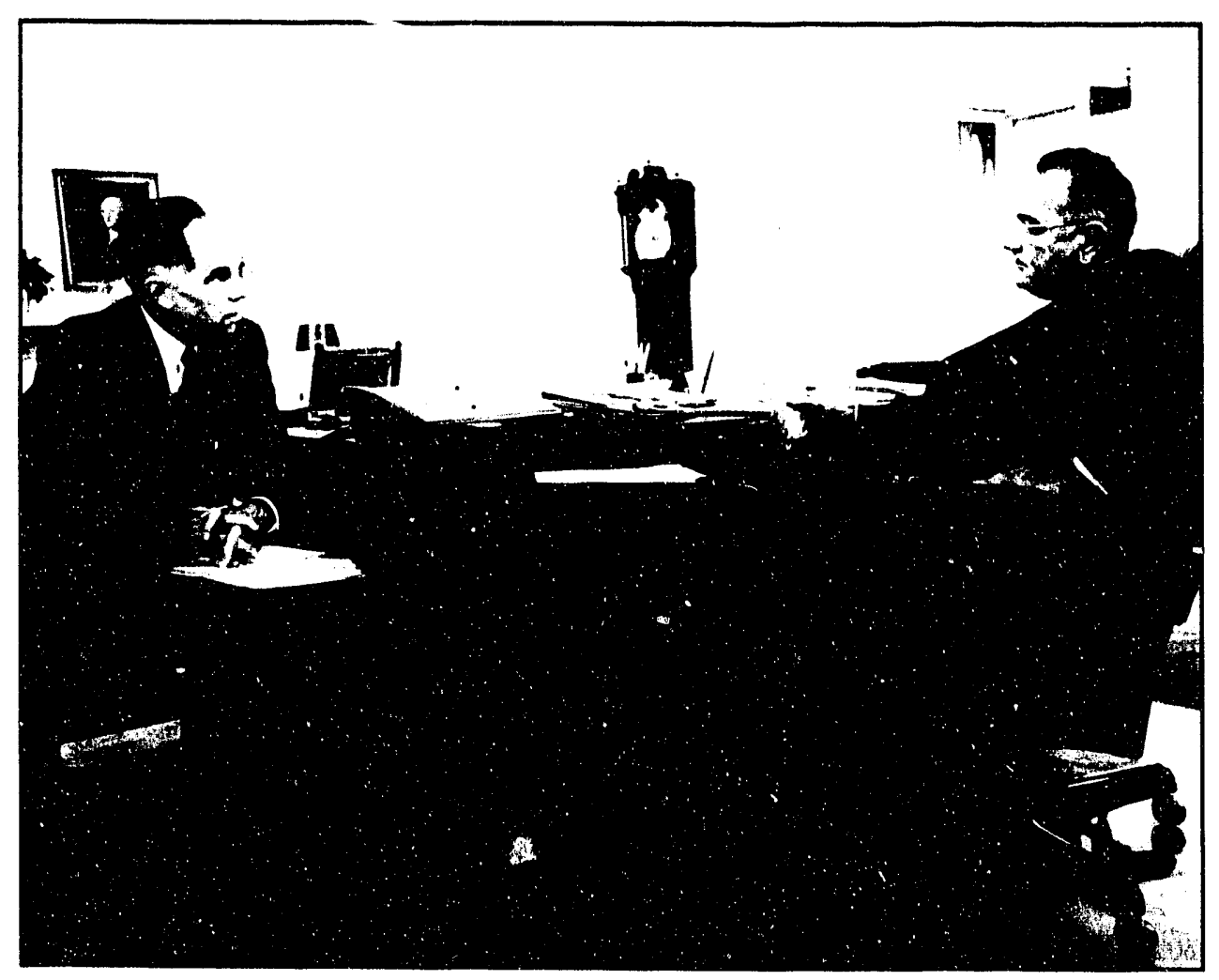


A heartwarming event took place on August 1, 1966:

"At 4:30 p.m. Helen, Pete, Lynne, Steve, Dave, Eric, Dianne and I attended the ceremony commemorating the 20th anniversary of the Atomic Energy Act which was signed in 1946, and also the swearing-in ceremony of Commissioners Samuel Nabrit and Wilfrid Johnson. The ceremony was held in the East Room of the White House. Helen and the kids met President Johnson in the receiving line following the ceremony. The President said, "Hi, Honey Bun!" to Dianne, which thrilled her very much. The Commissioners had their picture taken with the President. The White House photographer took individual pictures of the kids and Helen with the President. (Figures 31-36.) There was a large crowd of atomic energy, industry, Joint Committee on Atomic Energy, and academic people present at the ceremony."

A notable event was President Johnson's visit to the National Reactor Testing Station in Idaho. Quoting from my journal of August 26, 1966:

"At 9 a.m. I left Andrews Air Force Base on Air Force One (the President's plane) for Idaho Falls (via Pocatello) with President and Mrs. Johnson; we arrived at Pocatello at 9:45 a.m. I had an opportunity to talk with the President on the way and to brief him on the AEC's Nuclear Reactor Testing Station and the Idaho Operations Office. Upon arrival at Pocatello, the President was introduced by Congressman Compton I. White, Jr. of the Idaho Congressional delegation. The President then introduced a number of people on the platform, including me, and spoke generally on the U.S. domestic scene to a large crowd at the airport. Among those present at the airport were Commissioners Ramey, Tape and Nabrit; Fritsch, Rosel Hyde, John A. Carver; Representative Chet Holifield, Representative Wayne Aspinall, John Conway (Joint Committee on Atomic Energy); Idaho Senators Frank Church and Len B. Jordan; Idaho Representatives George V. Hansen and Compton I. White, Jr.; Ralph Harding; Idaho Governor Robert E. Smylie; Marvin Watson, John A. Carver, Jr., William L. Ginkel, Walter H. Zinn, Stephen Lawroski, A. $V$. Crewe, newspaperman Robb Brady (of the Post Register), and Meyer Novick.

After the brief ceremony [the President, ] Senator Frank Church, Chet Holifield, MIarvin Watson (Special Assistant to the President), and I boarded a helicopter [to travel] to the Central Facilities area of the National Reactor Testing Station (NRTS).

On the way, the President berated Marvin Watson for omitting the names of some of the people that he (the President) should have introduced at Idaho Falls. During the ride I had a chance to brief the President further on the NRTS.

At 10:40 a.m. we arrized at the Central Facilities and were met by William L. Ginkel (Manager, Idaho Operations Office). 


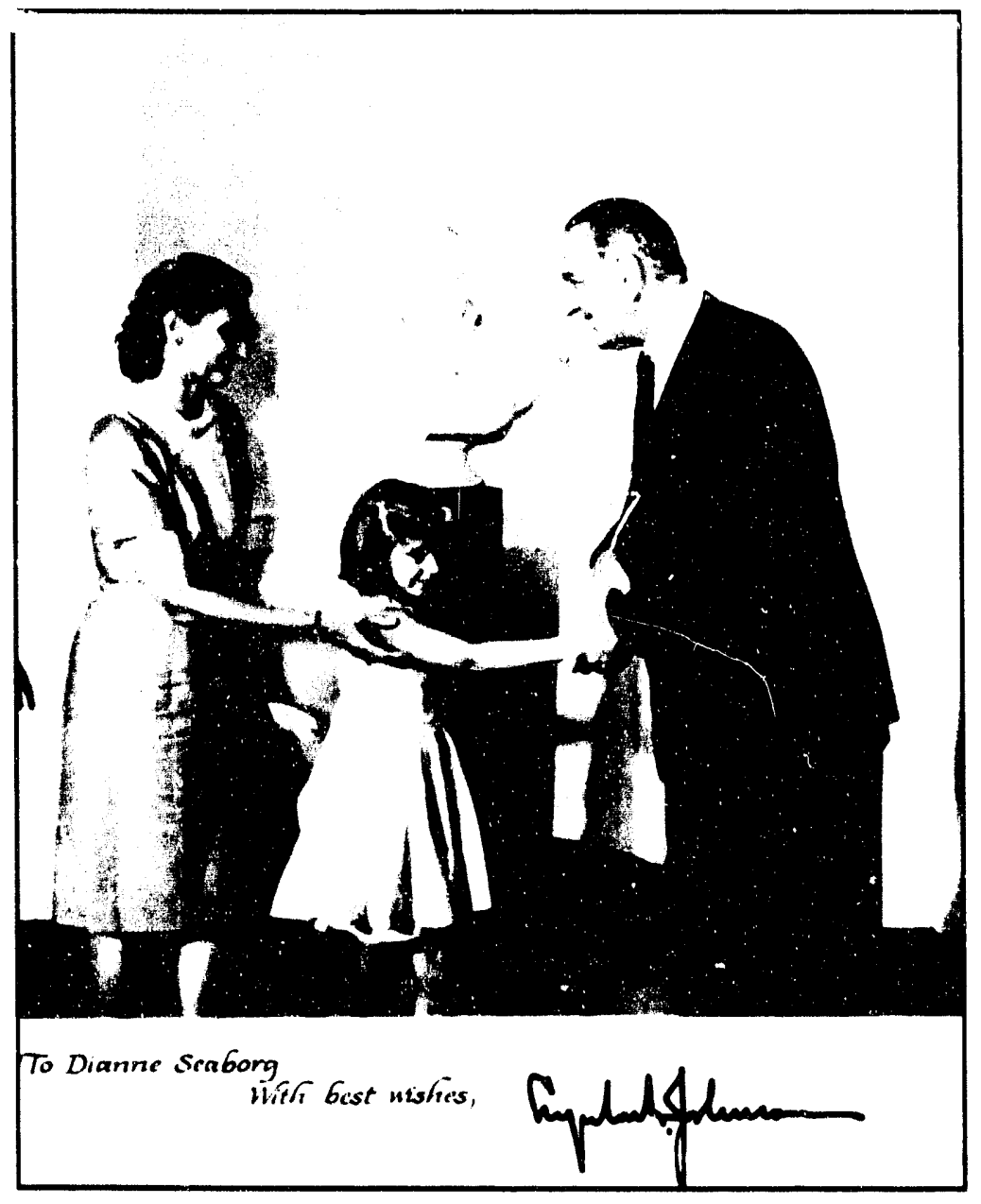

Figure 31.

Figures 31-36.

The Seaborg family meets President Lyndon B. Johnson, East Room, White House, August 1, 1966.

31. Helen (left) and "Honey Bun" Dianne. (Age 6)

32. Eric. (Age 11)

33. Stephen. (Age 15)

34. David. (Age 17)

35. Lynne. (Age 18) [David (center) with back to camera.]

36. Peter. (Age 20)

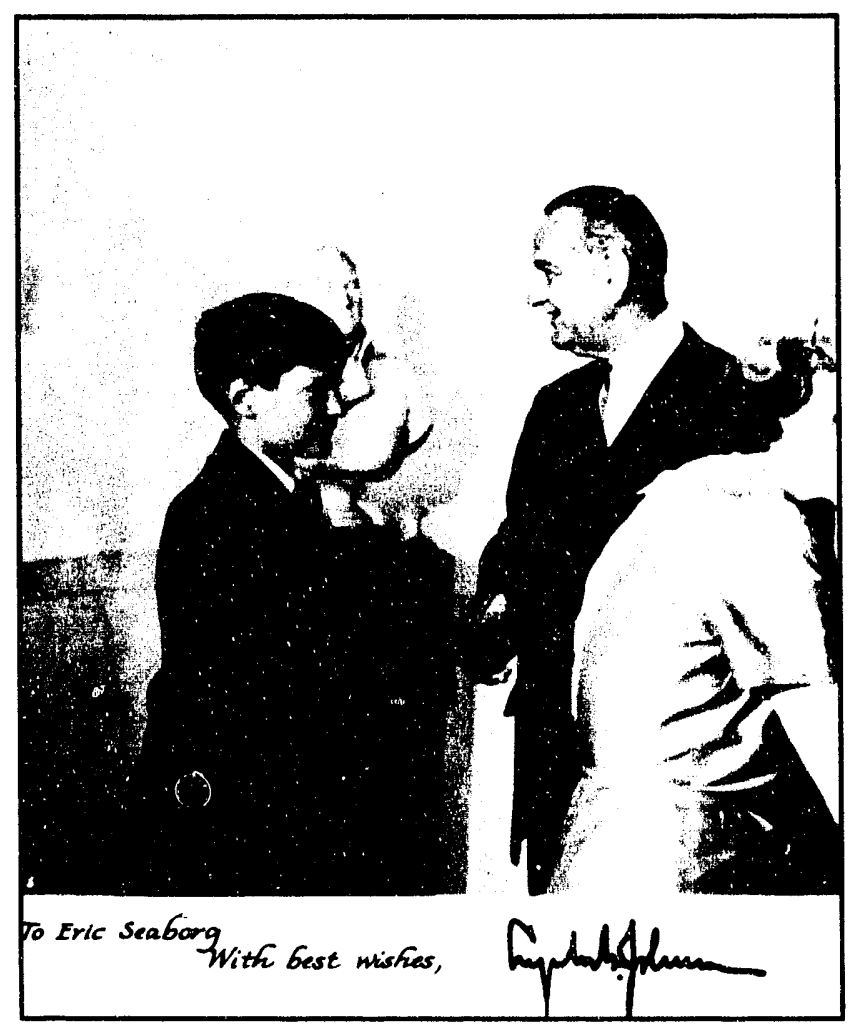

Figure 32.

$-52-$ 
Figure 34 .
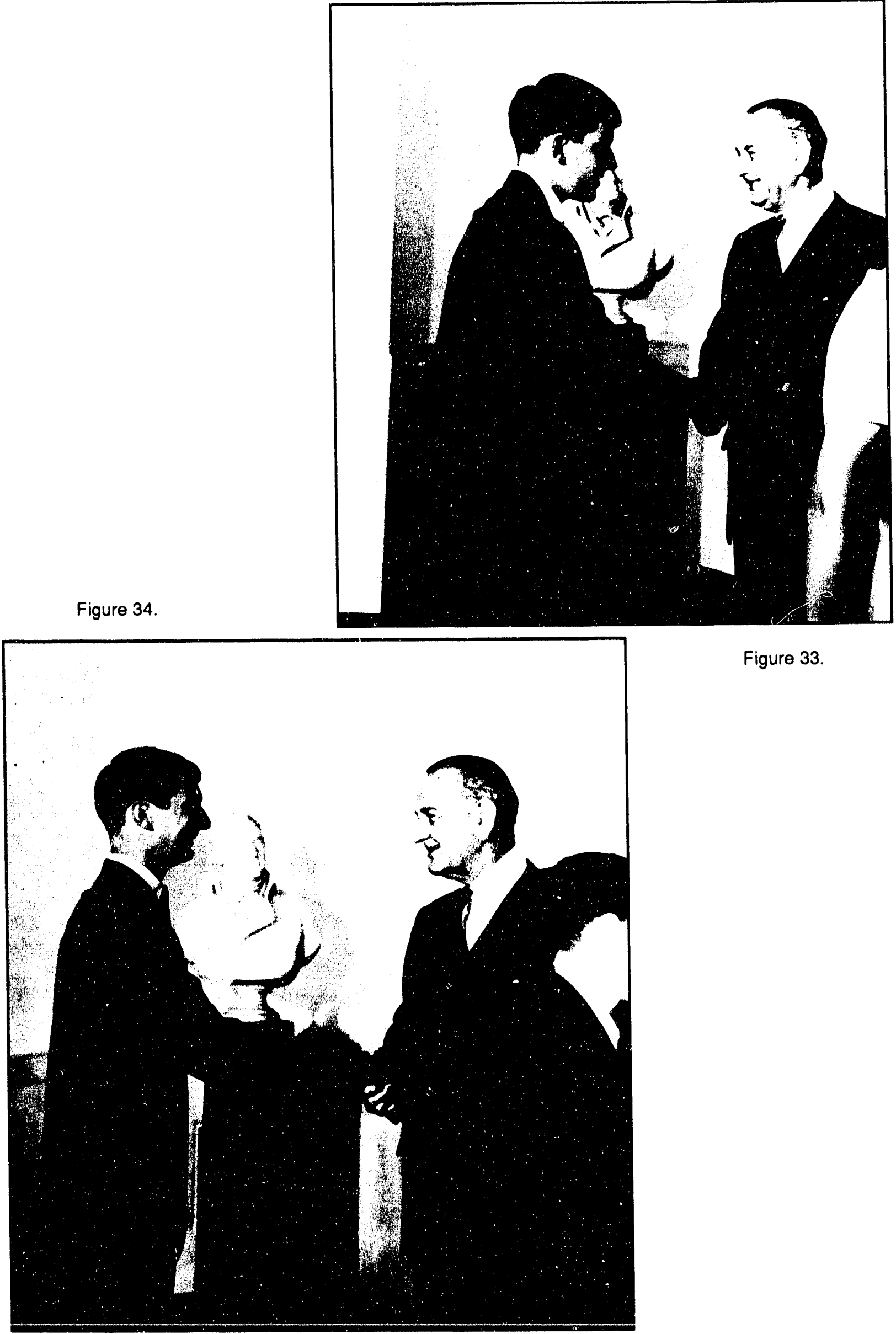

Figure 33. 


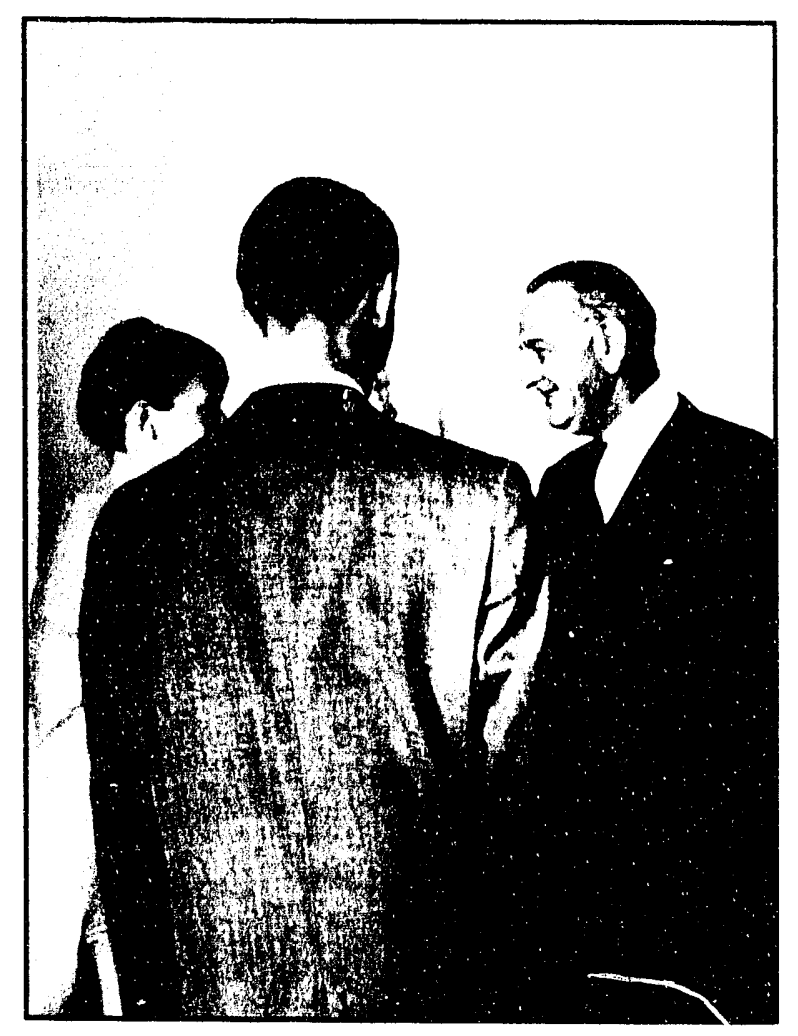

Figure 35.

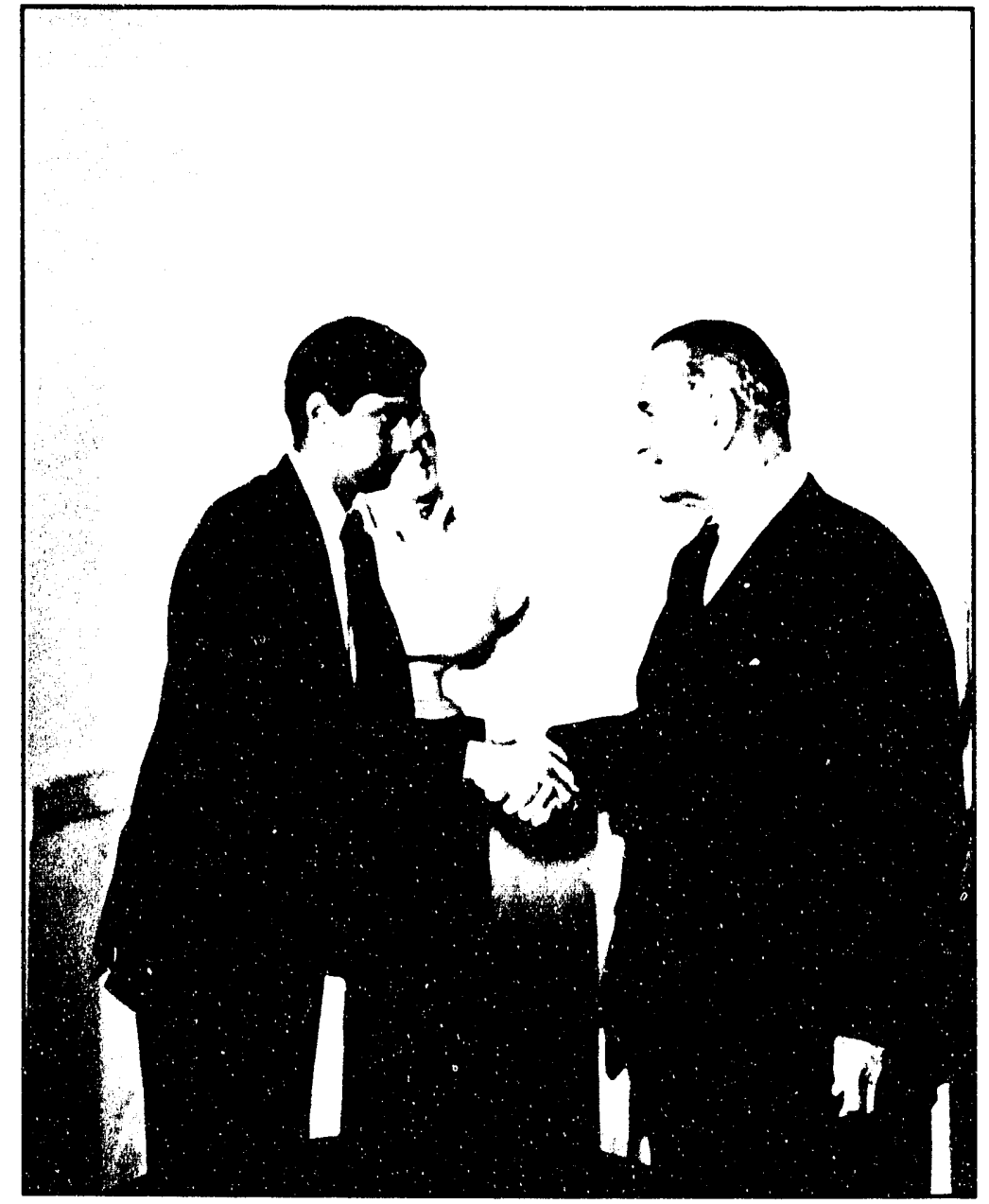

Figure 36. 
At 10:45 a.m. we attended the ceremony dedicating the Experimental Breeder Reactor No. 1 (EBR-1) of the National Reactor Testing Station as a National Historic Landmark. Commissioners Ramey, Tape and Nabrit, representatives from the Joint Committee on Atomic Energy, the Idaho Congressional delegation, Idaho state officials, and members of the Idaho legislature were included on the platform. William L. Ginkel made the introductory remarks and Governor Robert E. Smylie introduced the President. The President made an historic speech, using material prepared by the AEC on the growth and prospects of civilian nuclear power, and going into consideration of the nuclear threat and ways of alleviating it through U.S.-USSR actions, such as a nonproliferation treaty. The first part of his speech was marred by a faulty public address system set up by the White House staff, not the AEC. The television and radio reception was not impaired.

Following the President's speech, Ginkel introduced the people on the platform. He then introduced John A. Carver (Undersecretary, Department of Interior) who made the presentation of a plaque designating Experimental Breeder Reactor No. 1 as a Registered National Historic Landmark. I responded, first making reference to the difficulties with the public address system, alluding to the other technological accomplishments of the NRTS and thus the irony of such an occurrence, then going on to praise the Argonne National Laboratory for the advancement of peace and the peaceful uses of atomic energy. (I had some trouble with a slight lip bleeding at the end of my remarks, but I doubt it was noticeable.)

After the ceremony President and Mrs. Johnson and Stephen Lawroski in one car, with the Idaho Congressional delegation and me in the following cars, drove to the site of the Experimental Breeder Reactor No. 1. President Johnson and I used screwdrivers to finish putting the plaque on the wall of the reactor (while pictures were taken). (Figure 37.) President and Mrs. Johnson toured the area and the original EBR-1 group met the President and had their pictures taken with him. The President and his party then drove back to the Central Facilities and took a helicopter to Idaho Falls where the entire party, including Chet Holifield, proceeded to Denver and Tulsa. The President went on to Texas."

As indicated earlier (in Section 4), Vice President Johnson had visited, with President Kennedy, the AEC's Los Alamos Laboratory and Sandia Laboratory in New Mexico on December 7, 1962.

When the occasion called for it, Johnson withheld nothing in support of accomplishing his objective. At the meeting at the LBJ Ranch in December, 1966, I told him about a trip I was making to atomic energy installations in India and Pakistan, and mentioned that the State Department was strongly urging me to visit Bangkok, but that I found it difficult to do this since I felt that I had to be back in Washington by January 16. The following excerpt from my journal describes how LBJ changed my plans: 
“...The President asked why I felt that I need to be back then, and I said that, among other things, I feel I should be here when Congress is back. He said he does not think this is necessary and that I make such a good envoy that he thinks it is much more important that I take this trip and stay as long as necessary, even if it takes all of January. The President then turned to [Joseph] Califano and told him to arrange to place a converted 707 (i.e., a KC-135) at my disposal so that I could take some of my staff and colleagues. This would be

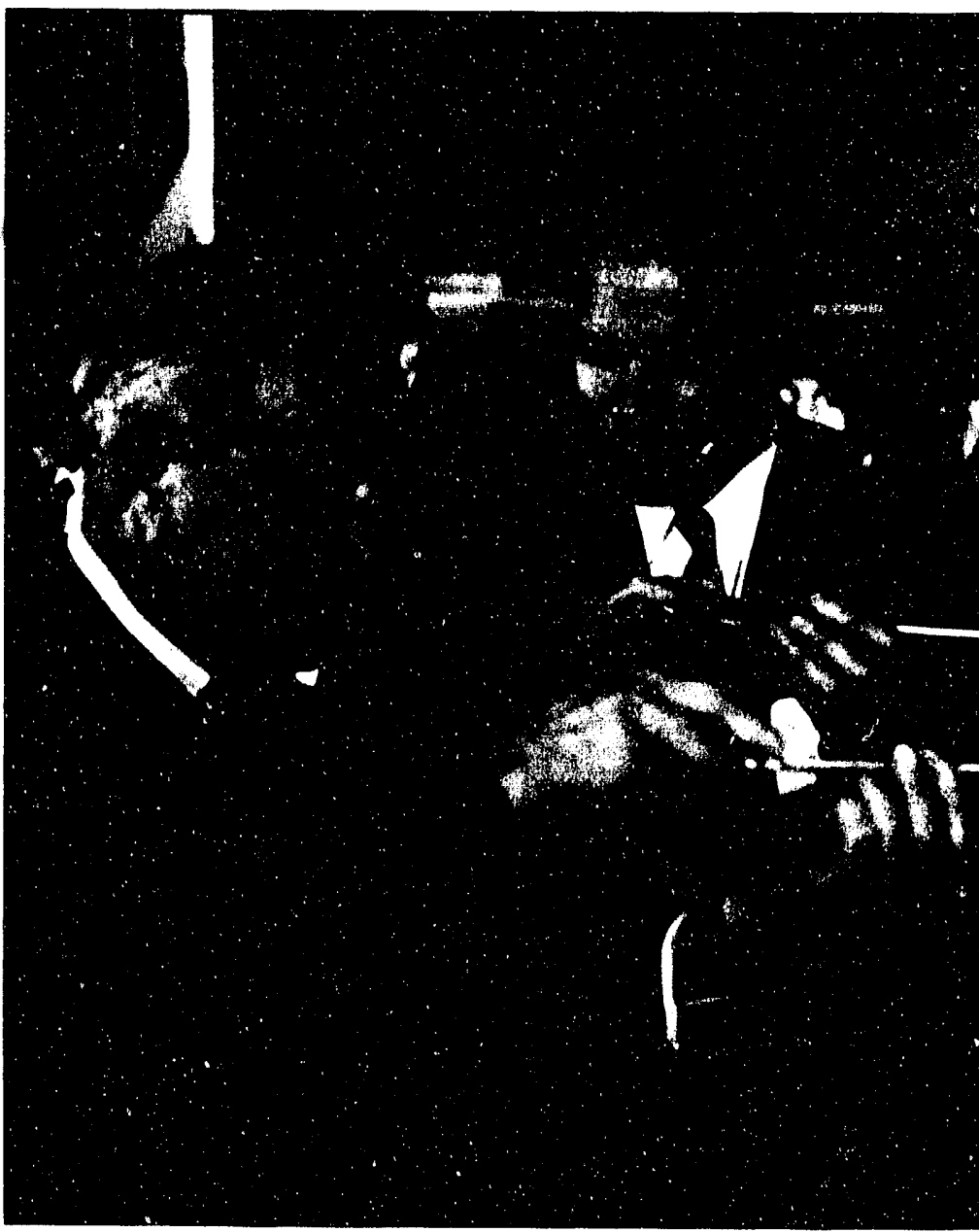

Figure 37. Johnson and Seaborg at the dedication of Experimental Breeder Reactor No. 1 as a National Historical Landmark, National Reactor Testing Station, ID, August 26, 1966.

Secretary

McNamara's

plane. The President suggested that I be given McNamara's pilot, and if he is not available, his (the President's) own pilot. He suggested that I give speeches on the peaceful uses of atomic energy, desalting, etc., and that I speak at universities, if possible. He suggested the inclusion of a press relations man, a steward, lour wives], and a doctor, if that would be helpful."

As a result, we had a very successful trip around the world--visiting Australia, Thailand, India, and Pakistan--with my wife Helen and AEC Commissioner Gerald Tape and his wife Jo as members of our group.

A noteworthy occasion involving President Johnson was the 25 th Anniversary Observance of the first Nuclear Chain Reaction at the University of Chicago on December 2, 1967: 
"Following the warm-up session, I opened the program carried on satellite television between Italy and the United States by sending greetings to some of the group at the capitol in Rome (President Guiseppi Saragat, Minister of Industry and Commerce Giulio Andreotti, and Professor Carlo Salvetti). I made a few remarks about the significance of the Fermi experiment. I then introduced to the television audience Mrs. Fermi, the Fermi team as a group, Walter Zinn, Herbert Anderson, Mrs. Compton, Emilio Segrè, General Groves, Ambassador Ortona, Mayor Daley, and President Beadle. (Figure 38.) I then introduced President Johnson, in Washington, D.C., who spoke for 10 to 12 minutes on the significance of the Fermi experiment, the peaceful uses of nuclear energy, suggested the $200 \mathrm{BeV}$ Accelerator be "dedicated to Enrico Fermi and said we would place our U.S. peaceful nuclear program under IAEA Safeguards as soon as a nonproliferation treaty was in effect. I then switched the program to Rome where President Saragat spoke from the capitol where a very impressive auditorium full of people was assembled. I then brought the program to a close by thanking President Saragat,

President Johnson and the Fermi team. Although the program was not broadcast domestically, the major television networks taped it for later broadcast."

President Johnson continued President Kennedy's custom of presenting the AEC's Fermi Award to the recipients. After some hesitation due to the anticipated strenuous disapproval by some members of Congress, Kennedy had approved the presentation of the \$50,000 Award to J. Robert Oppenheimer. Johnson unhesitantly agreed to go ahead with the presentation on December 2, 1963:

"The presentation of the seventh Fermi Award to Robert Oppenheimer took place at the White House at 5 p.m. I presented Oppenheimer to President Johnson, who made a very moving presentation. (Figure 39.) Oppenheimer made an excellent response. Just before the ceremony Helen and I, Robert and Kitty Oppenheimer and their children, Peter and Tony, and Mrs. William S. Parsons met with President and Mrs. Johnson in his office. The ceremony, held in the Cabinet Room, was attended by a larger group than either of the two previous ceremonies held in the White House and the arrangements for this ceremony were better than for previous ones. After the ceremony Heler and I hosted a reception at the National Academy of Sciences, which was attended by about 150 people."

His last presentation of the Fermi Award, reduced in amount to $\$ 25,000$ due to the adverse reaction to the presentation of the award to J. Robert Oppenheimer by some adamant members of Congress, took place on December 2, 1968, when he made the presentation to John A. Wheeler:

"At 5:30 p.m. Helen and I attended the Fermi Award Ceremony in the East Room of the White House. Some 50 to 100 people were present. President Johnson presented the 10th Fermi Award to John A. Wheeler (Figure 40.) in the presence of Mrs. Wheeler, his father, his son, and grandson. I opened the ceremony with a few remarks, then President 


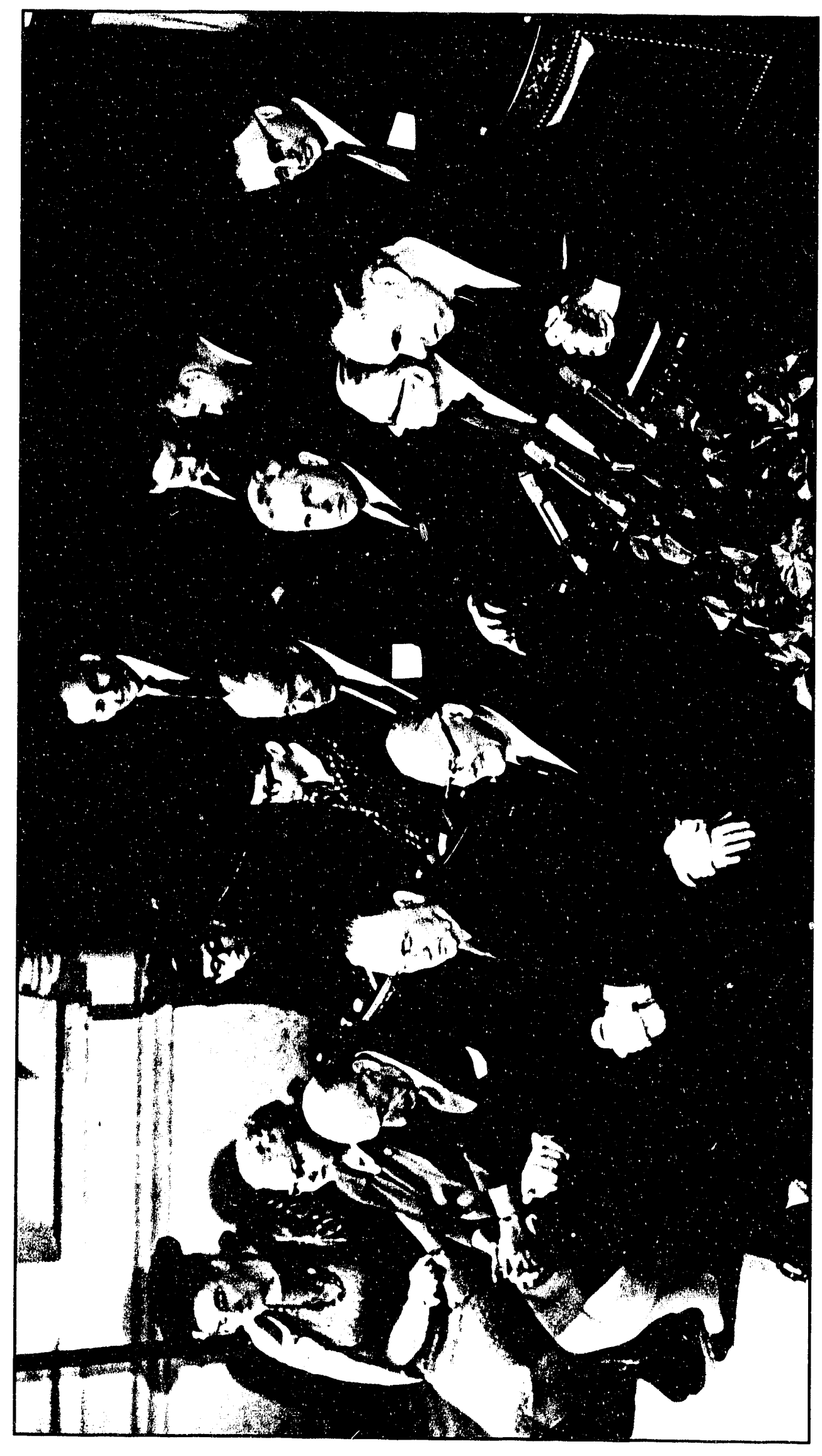

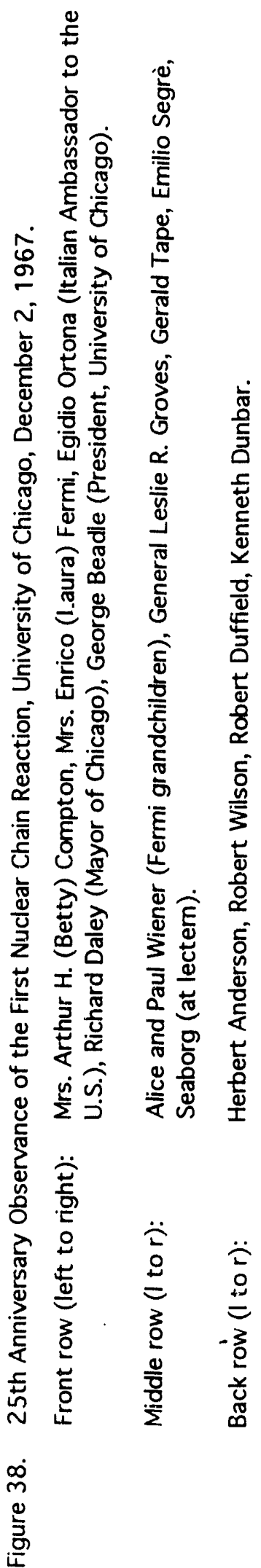




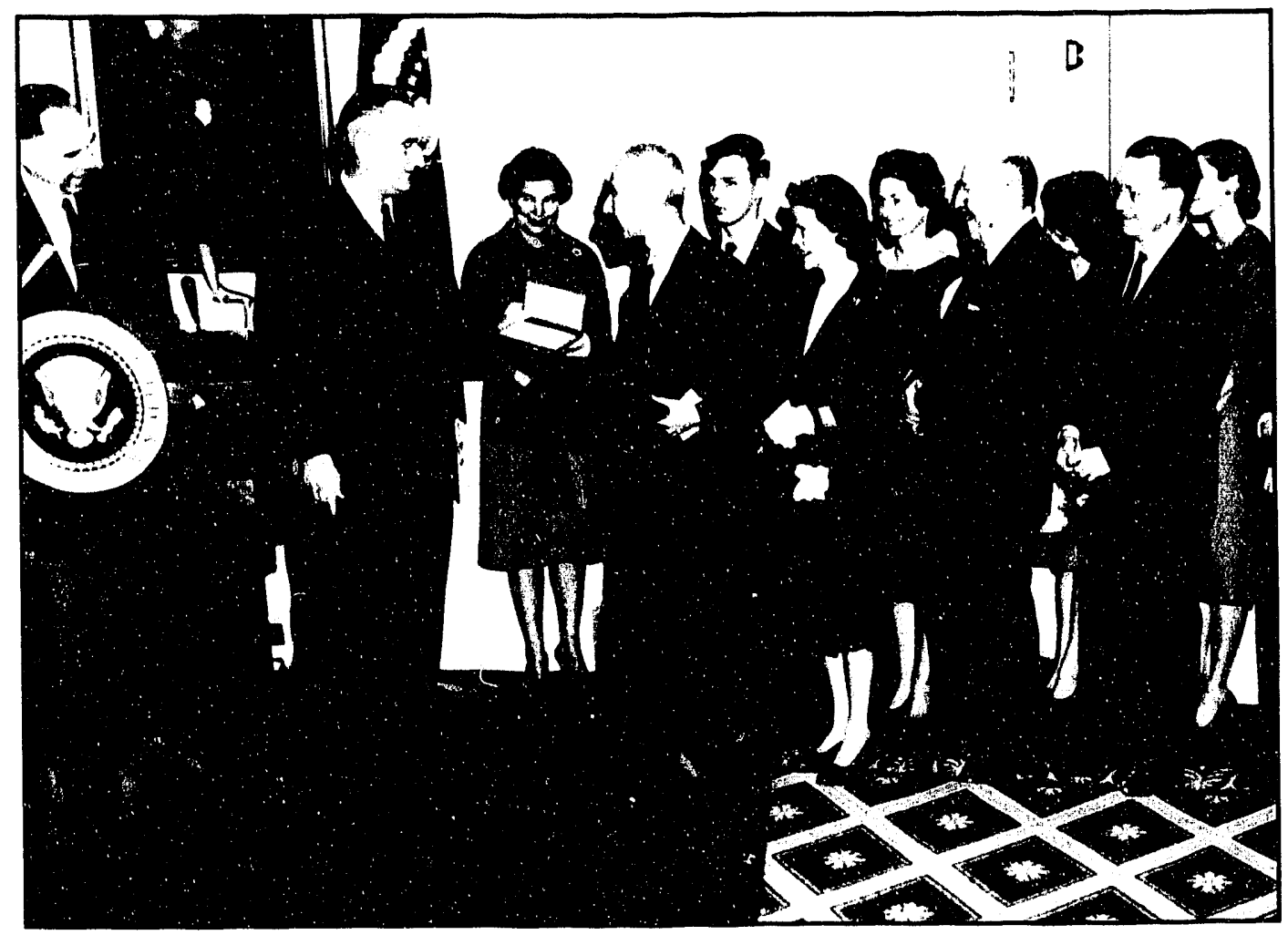

Figure 39. AEC's Enrico Fermi award presentation to J. Robert Oppenheimer, White House, December 2, 1963.

Left to right: Seaborg, Johnson (presenting award), Mrs. William S. Parsons, Oppenheimer, Peter Oppenheimer, Kitty Oppenheimer, Lady Bird Johnson, Robert E. Wilson, James T. Ramey, and Helen Seaborg.

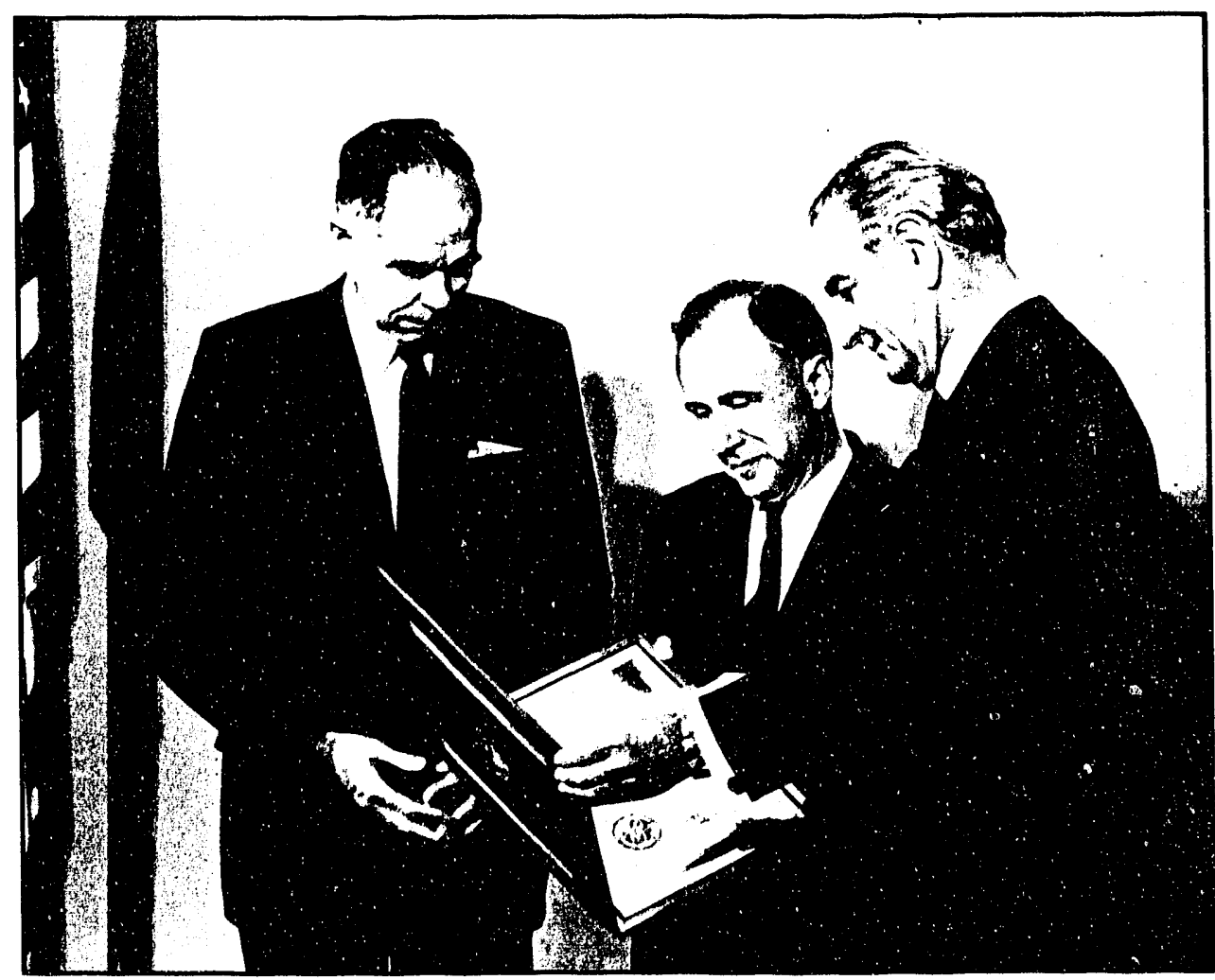

Figure 40.

(left)

AEC's Enrico Fermi award presentation to John A. Wheeler, White House,

December 2, 1968.

Left to right:

Seaborg, Wheeler, and Johnson 
Johnson made his remarks, I read the citation, the President presented the citation, a $\$ 25,000$ check and gold medal to Wheeler, and Wheeler made his response. The President was in a very good humor and made some very flattering remarks about me during his talk and also as I prepared to read the citation. He said that I have been consistently successful in getting what I want in my budget appeals to him and I responded by suggesting that this might be an invitation with regard to this year's budget. Following the ceremony we went to the Blue Room where pictures were taken of the Wheelers with the President and also of the five Commissioners with the President."

I had convinced the president to make the offer to place our U.S. peaceful nuclear facilities program (i.e. our civilian nuclear power reactors) under AEC Safeguards--this was the step that broke the logjam in obtaining the NonProliferation Treaty the following year (1968).

The dinners in the White House were similar to those that Helen and I had attendeci during the Eisenhower and Kennedy administrations. Following initial greetings in the East Room and the dinner in the State Dining Room, the guests gathered in the intervening rooms (the Red, Blue and Green Rooms) for conversation before going back to the East Room for the entertainment. For example, on Novemiver 14, 1967, Helen and I attended a White House dinner given by President and Mrs. Lyndon Johnson in honor of Prime Minister and Mrs. Eisaku Sato of Japan. President and Mrs. Johnson welcomed their guests at the North Portico entrance. After the usual pre-dinner reception in the East Room, the guests proceeded to the State Dining Room and the Blue Room. I sat at a table with Mrs. Kenneth H. Burns (Washington, D.C.), Congressman Charles N. Youngblood (Michigan), Mrs. Leo Jaffe (Leo Jaffe was President of Columbia Pictures), Arnold Olsen (Montana), and Mrs. Rosel Hyde (Hyde was Chairman of the Federal Communications Commission).

Preceding his toast to Japan and its emperor, President Johnson referred to Abraham Lincoln: "Lincoln gave us a faith that no time or crisis can kill. It took time and patience, but Lincoln won peace at home. It is taking time and patience to win peace in the war." I believe that he had in mind the war in Vietnam. Then Johnson quoted these words of Lincoln--"I am here. I must do the best I can, and bear the responsibility of taking the course which I feel I ought to take." Pursuing this theme in his response, Prime Minister Sato praised the president for his war efforts.

President Johnson seemed to be in unusually good spirits and spent time with nearly every one of the approximately 185 guests, paying particular attention to the leaders of the new D.C. government. Besides President and Lady Bird Johnson, Helen and I talked to, during the evening, Vice President and Mrs. Hubert Humphrey, the Ambassador of Japan and Mrs. Shimada, Florida Representative and Mrs. Claude Pepper, Tennessee Representative and Mrs. Joe Evins, Texas Representative and Mrs. Jim Wright, General and Mrs. Maxwell D. Taylor, D.C. Mayor and Mrs. Walter E. Washington, Dr. and Mrs. Leland J. Haworth (Director, National Science Foundation), Richard Adler (composer), Mr. and Mrs. Kirk Douglas (actor), Mr. and Mrs. Robert Gibson (baseball pitcher), Mr. and Mrs. Frank Stanton (President, CBS), Mr. and Mrs. Wernor P. Gallander 
(President, National Association of Manufacturers), Illinois Governor and Mrs. Otto Kerner, Tony Bennett (popular singer), Mr. Howard Duff (actor) and his wife Ms. Ida Lupino (actress), General and Mrs. William D. Eckert (Commissioner of baseball, New York), and West Virginia State Representative and Mrs. John D. Rockefeller IV, and others.

After dinner we all went to the East Room, where Tony Bennett, accompanied by a five-piece orchestra, entertained everyone by singing his famous "I Left My Heart in San Francisco," and many other songs, including "Country Girl," which he dedicated to "our great President Johnson." It was a lively and very interesting evening.

Lyndon Johnson was dedicated to the goal of equal opportunity for all Americans. As I can testify from first-hand experience, Johnson was very determined that women and minorities be represented in the appointments to the five-member Atomic Energy Commission. In effect, twenty-five years ago, Lyndon Johnson anticipated and promulgated the importance of "diversity" to our nation, which we as a nation are only now beginning to recognize and advance. I and my fellow Commissioners were ordered to help him find a woman and an African American [then called Negro] for appointment to the Commission. This commitment resulted in the appointment of Mary (Polly) Bunting (President of Radcliffe College) and Samuel Nabrit (President of Texas Southern University), both of whom served with distinction.

Although in some ways LBJ was larger than life, towering over others both physically (although I had the advantage of being close to, even exceeding, his height) and emotionally, in the sense of his exuberant personality filling the rom, he was, nonetheless, very human. In the midst of the Vietnam War, it became more and more clear how much the war weighed on him, and he showed this to others. I doubt that anyone will ever forget when he went on television to announce that he would not seek re-election, a speech in which he revealed his vulnerability about what history would have to say of him. He did take pride in much that was accomplished by his administration in the domestic area. His commitment to The Great Society was very real and obviously, he had never forgotten the poverty of his youth and his desire to improve the lot of poor or disenfranchised Americans. I suspect that in the long run history will recognize these accomplishments and credit LBJ's dedication and determination. I know that I will long remember the genuine warmth of his friendship which was based on the solidest foundation for friendship, mutual respect.

During the last month of the Johnson Administration, I was interviewed on audiotape by AEC historian Richard G. Hewlett, and the tape and a transcript are deposited in the Lyndon B. Johnson Library in Austin, Texas. Helen and I were present for the dedication of the Library on May 22, 1971:

"We arrived at Bergstrom Air Force Base, Austin, Texas, at 10:40 a.m. and proceeded by bus to the University of Texas campus. Here we attended the dedication of the Lyndon Baines Johnson Library and the Lyndon Baines Johnson School of Public Affairs conducted in the glade next to the circular water pool adjoining these buildings. The Reverend Billy Graham gave the invocation. Frank C. Erwin, Jr. (former Chairman 
of the Board of Regents of the University of Texas) presided and introduced those on the platform, including Mrs. L. B. Johnson, Mrs.

Richard M. Nixon, Vice President Spiro Agnew, Carl Albert, Secretary William Rogers, Secretary John Connally, Preston Smith, Texas Legislature Speaker Gus Macher, Lieutenant Governor Ben Barnes, Robert L. Kunzig (GSA Administrator), Harry Middleton (Director of the LBJ Library), John Gronouski (Dean of the LBJ School of Public Affairs), Bryce Jordan (President of the University of Texas at Austin), and Harry Ransom (Chancellor Emeritus, the University of Texas System).

Erwin then called on Ransom, who spoke briefly giving the background for the Library.

Erwin then called on Lyndon Johnson who described the contents of the Library (covering 31 million papers and 40 years of his Washington public papers, gifts, historical documents, etc.) and its purpose. He expressed his philosophy in two words: "Man can."

Erwin then introduced President Nixon who emphasized the value of the Library and of Lyndon Johnson's great public service. The President mis-spoke and said that President Johnson had just finished "throwing" him through the Library; he had meant to say "showing" him through the Library, of course, and corrected himself immediately.

Erwin then introduced, as members of the audience, David and Julie Eisenhower, Chuck and Lynda Bird Robb, Patrick and Luci Nugent and their son Lyn.

At the conclusion of the dedication Reverend George R. Davis (National City Christian Church of Washington, D.C.) gave the benediction.

Immediately after the end of the ceremony I watched President [and Mrs.] Nixon and President [and Mrs.] Johnson as they walked up the path to the Library and, as he passed, President Nixon said to me, "Hi, Glenn." I took some pictures with my Minox camera as they passed (as I had earlier, during the ceremony)." (Figure 41.)

I met Lady Bird Johnson again when she spoke on the "Beautification of America" at a Commonwealth Club luncheon at the Palace Hotel in San Francisco on February 19, 1988. (Figure 42.)

I met Hubert $\mathrm{H}$. Humphrey a number of times beginning when he was first elected as a U.S. Senator from Minnesota, and continuing through his vice presidency under Lyndon Johnson, when he served as chairman of the Space Council and of the Marine Resources Council, upon which I served as a member. I recall that he had me assume the chairmanship of the Marine Resources Council when he was unable to attend. I also had the opportunity to introduce him for 


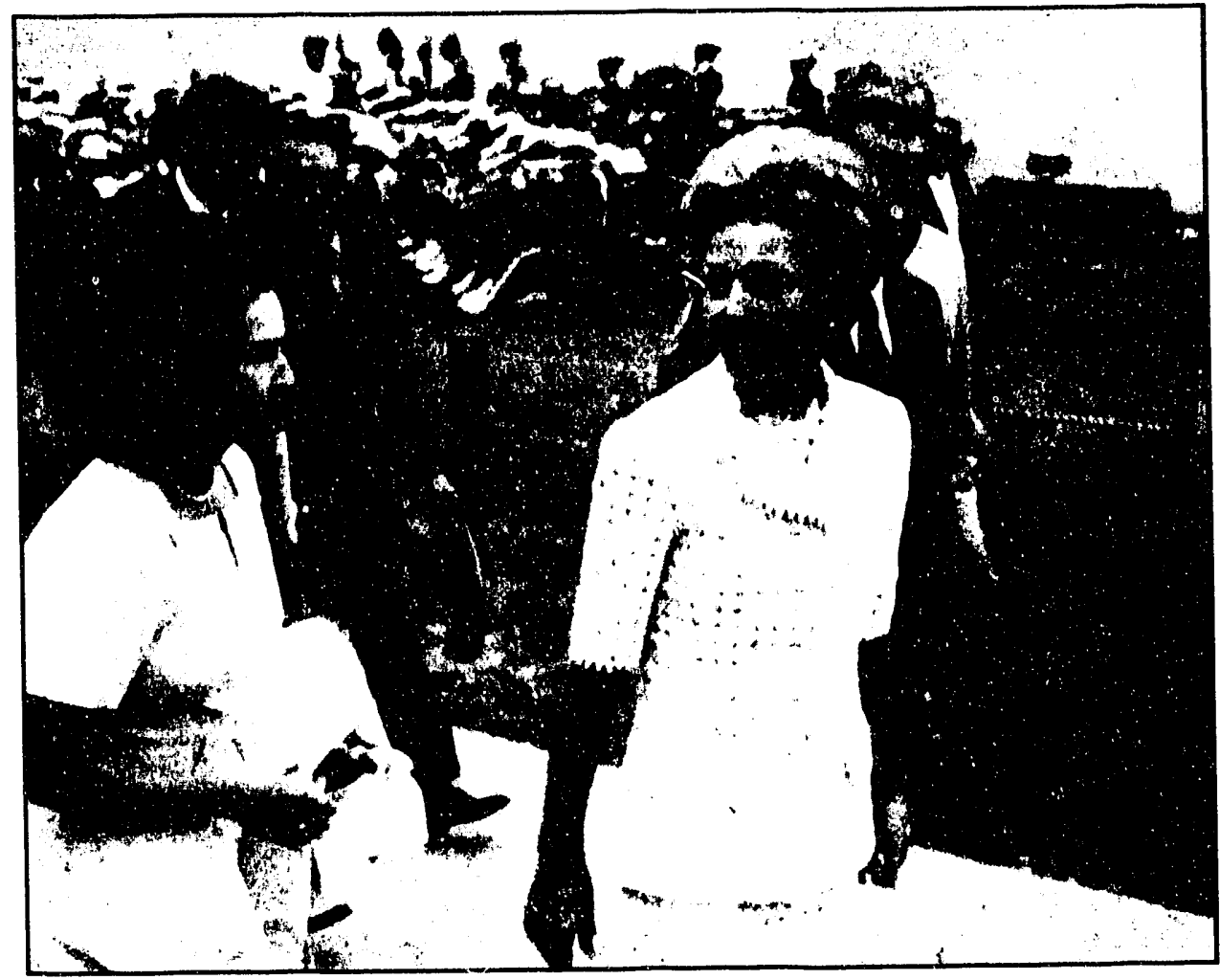

Figure 41.

(above)

Dedication of the Lyndon Baines Johnson Library and the Lyndon Baines Johnson School of Public Affairs, University of Texas, Austin, TX, May 22, 1971.

Lady Bird Johnson (left) and First Lady Pat Nixon with President Richard Nixon and President Lyndon Johnson (behind Mrs. Nixon) in background. (Photo taken by Seaborg with his Minox camera.)

Figure 42

(right)

Lady Bird Johnson and Seaborg at the luncheon of the Commonwealth Club, Palace Hotel, San Francisco, February 19, 1988.

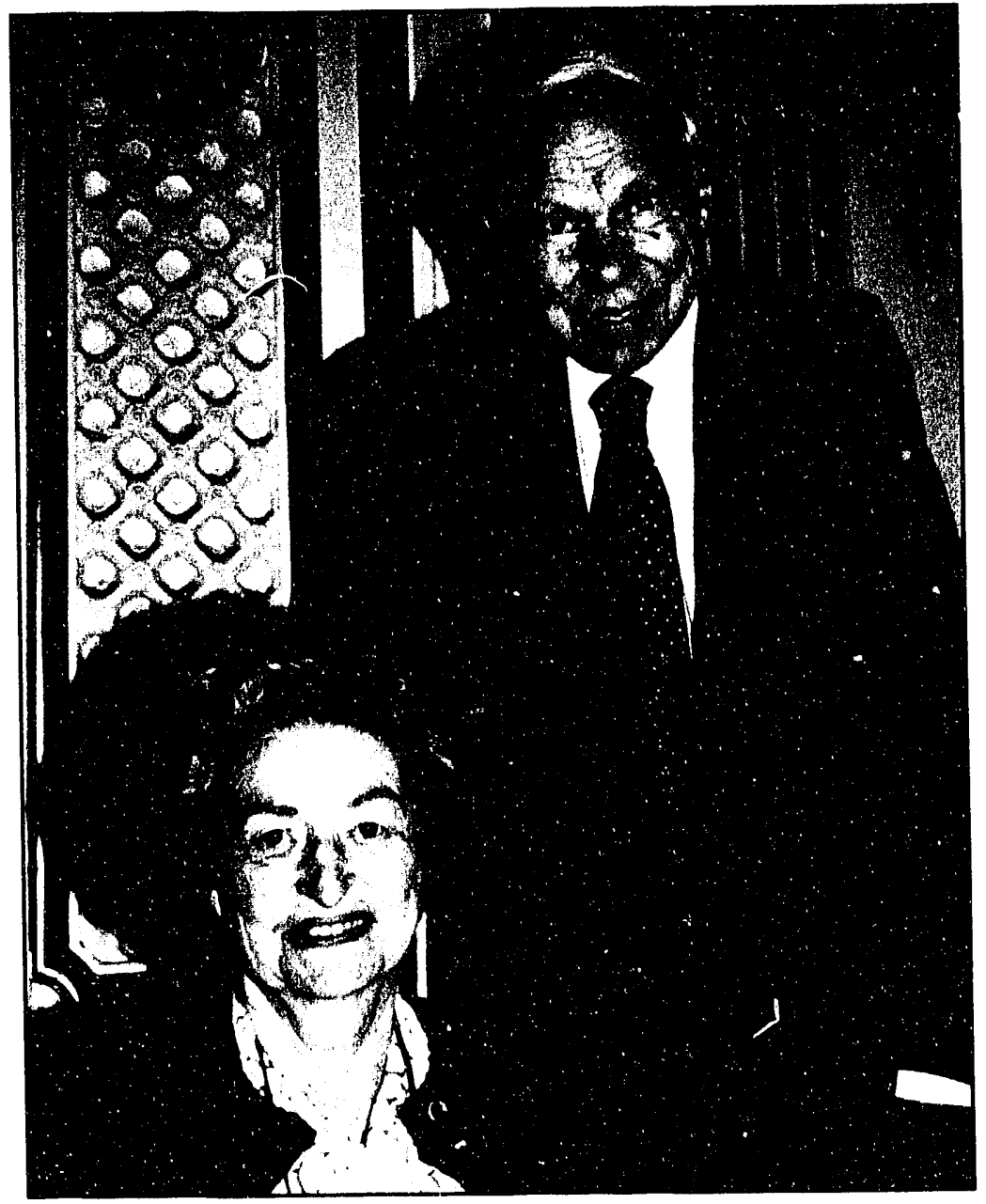


his talks to various organizations on a number of occasions--especially memorable for me was my introduction, as president of Science Service, for his talk at the Science Talent Search banquet at the Sheraton Park Hotel on March 6, 1967. (Figure 43.)

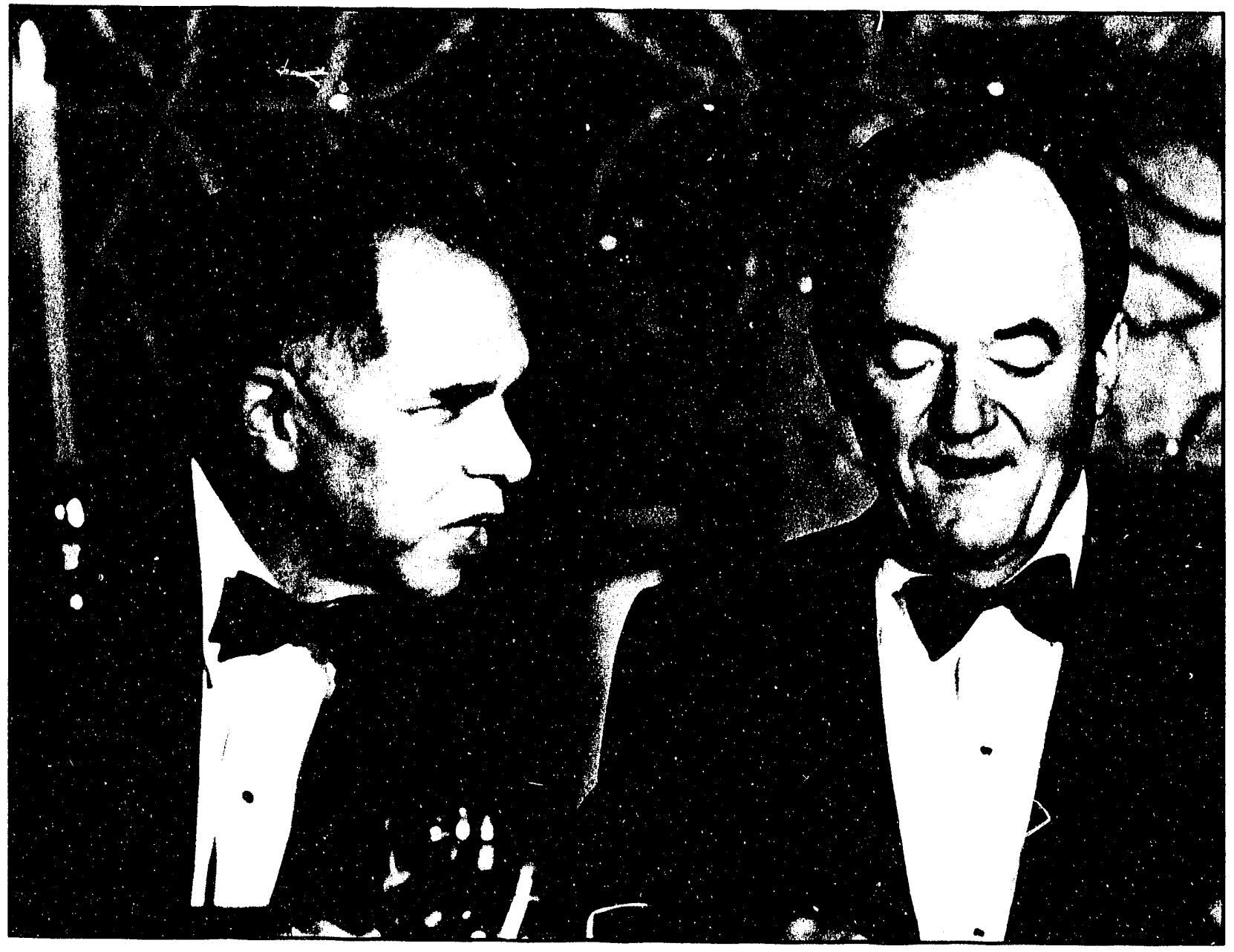

Figure 43. Seaborg with Vice President Hubert H. Humphrey at Science Talent Search dinner, Sheraton Park Hotel, Washington, D.C., March 6, 1967.

In summary, I would describe President Johnson as a master politician, the possessor of a very interesting and complex personality (indeed, the most compelling I have known), a good friend or formidable adversary, and an energetic worker and effective performer. I was pleased to be counted among his friends. 


\section{Richard Milhous Nixon}

I first met Richard M. Nixon soon after he had been elected as a U.S. Congressman from California. We met on the occasion of the banquet for the U.S. Junior Chamber of Commerce's Ten Outstanding Young Men of 1947, held in Chattanooga, Tennessee. (Figure 44.) Quoting from my journal for January 21, 1948:

"In Chattanooga. Some of the "Ten Outstanding Young Men," at Missionary Ridge, where an exceedingly bloody battle took place in November of 1863.

The list of the "Ten Outstanding Young Men of 1947" includes Cord Meyer, Jr. (27, President of the United World Federalists, New York), Dr. Robert A. Hingson (34, among the first to use the new invention hypospray and a developer of caudal anesthesia to eliminate childbirth pain, Memphis), De Lesseps S. Morrison (35, Mayor of New Orleans), Lavon P. Peterson (28, blind founder of an engineering school for the blind, Omaha), Glenn T. Seaborg, Glenn Robert Davis (33, congressman, Waukesha, Wisconsin), James Quigg Newton, Jr. (35, Mayor of Denver), Richard M. Nixon (34, congressman, Whittier, California), Adrian Sanford Fisher (33, Atomic Energy Commission counselor, Washington, D.C.), and Thomas R. Reid (33, human relations expert, Baltimore).

All of us, except Reid and Morrison who were absent from the ceremonies, were honored, along with Harold Stassen (Republican candidate for President and the main speaker), by a reception in the Sun Room of the Read House at 5:40 p.m. Then at 7:30 p.m. we were introduced on $A B C^{\prime}$ 's Vox Pop radio program, which originated as a national broadcast from Chattanooga High School. Highlighting the Vox Pop program for me was Barbara Jo Walker of illemphis, "Miss America" for 1947. After the 8:30 p.m. banquet and Stassen's talk, we were presented at about 10:30 p.m. with ruby-studded Distinguished Service Keys in a ceremony broadcast over the ABC radio network. John Shepperd, President of the U. S. Junior Chamber of Commerce, presented the keys individually at the center mike. We each expressed our appreciation, and then Cord Meyer gave the response from the honorees. Paramount News filmed the ceremony.

It was a full evening, but it did have its lighter moments. A high school student asked me, "When you were doing that work, did you know you were going to make that discovery?" When I said, "No," he responded with, "Oh, you mean you were just piddling around?" I then replied, "I guess that's about the best definition of science yet."

Nixon suggested to me that we should remain in touch with each other and 'stick together.'" 


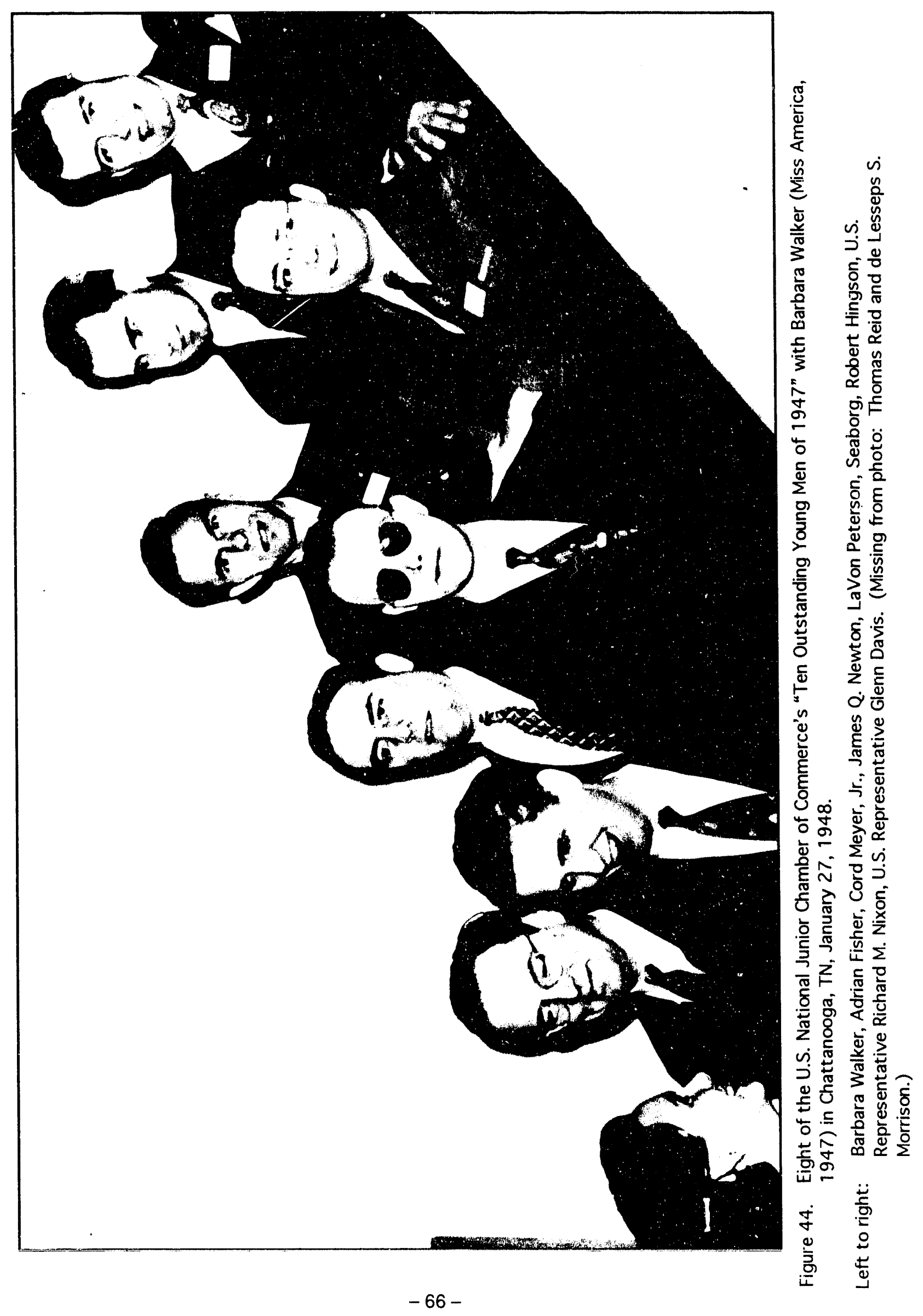


I next encountered Nixon when he was a candidate for the U.S. Senate and visited us in the Radiation Laboratory on Friday, May 26, 1950:

"As scheduled, I gave Richard Nixon and his entourage a tour through our chemistry research labs. Even Al Ghiorso was polite (but cool). When one of Nixon's aides announced that he (Nixon) and I were going to the Claremont Hotel for a photographic session, I realized that such photographs would constitute my endorsement of Nixon's candidacy. I promptly and ineptly refused--however, Nixon quickly and gracefully accepted my excuse."

I then encountered Nixon at the New Year's Day Rose Bowl game on January 1, 1951:

"Before taking our seats at the game, we visited the restrooms and, while waiting for Helen and Jeanette, I saw Senator Richard Nixon, whom I have known since 1948 when we were both honored by being chosen one of the nation's ten most outstanding young men. For some reason whenever I think of Richard Nixon, I am reminded of Dr. James Nickson, whom I knew during my Met Lab years, so I introduced Bill to James Nixon. When Nixon moved on, Bill remarked that he thought Nixon's first name was Richard."

I had a number of contacts with Vice President Nixon while I was Chancellor including an exchange in March, 1959, when he sent a message of congratulation to our University of California at Berkeley's NCAA Championship basketball team. On April 30, 1959, I met with Nixon in his vicepresidential office in the Capitol Building. We discussed a number of matters, including the student exchange program with the Soviet Union, the widespread dissatisfaction in the academic community over the Loyalty Oath demanded by the National Defense Education Act (NDEA)--and the story on the naming of mendelevium, in case this might be useful on his forthcoming trip to Russia.

Vice President Nixon made good use of the information about the naming of mendelevium. In August I received a package, containing a precious book autographed by Mendeleev from Emmanuel Tsipelzon with a translation from Russian to English by Edward L. Freers of the American Embassy in Moscow of the following message:

"During this visit to the U.S.S.R., Vice President, U.S.A., R. Nixon informed us that before his departure for the Soviet Union he was visited by his friend, professor of chemistry, Mr. Seaborg, who named the 101st element, discovered by him, of the D.I. Mendeleev Periodic Table after this great Russian chemist.

In this friendly act of the American scientist each Soviet citizen discerns a great respect toward our people and its culture, as well as one of the steps toward the liquidation of the absurd, according to Nikita Sergeevich Khrushchev, tense state of "cold war" between two great nations. 
May I present to you, in commemoration of your remarkable discovery and your noble act, the book by Dmitrii Ivanovich Mendeleev "Fundamentals of Chemistry" with his autograph.

The autograph read:

'To my deeply appreciated colleague, Dr. N.I. Bistrov, in commemoration of saving my son.

(Signed)

D. Mendeleev

1889.'”

This letter from Tsipelzon, who described himself as "an old Moscow second-hand book dealer," goes on to explain that Mendeleev presented this book to Bistrov when he arrived back in Moscow, having left the meeting of the Royal London Society where he was to read a paper because he heard that his son was deathly ill, and discovered that thanks to Bistrov, his son was already on the road to recovery.

I next met with Vice President Nixon in his office in the Capitol Building on December 14, 1959, when I was in town for a President's Science Advisory Committee meeting. We discussed the problems in pre-college education, the potential use of TV in education, the need to remove the disclaimer provision of the student loan section of the NDEA, and the prospects for the 1960 presidential race. He believed that the Republican nomination would go to either himself or Nelson Rockefeller, and he thought the Democratic nomination would go to either Stuart Symington or Adlai Stevenson.

On May 16, 1960, again in connection with my visit to Washington for a PSAC meeting, I met with Nixon, who was then a clearly identified candidate for the presidency of the United States. We discussed the future of PSAC (he said he intended to keep the same members, but would pick a new chairman), the need for federal support of private and state universities (he said that such support should extend beyond that for building programs to include faculty salary, scholarships, and so forth), and the plans for the support of the Lawrence Hall of Science (he said that he would see to it that this receives federal support and that this would be his first campaign promise).

At the time of the June, 1960, PSAC meeting in Washington, my two oldest children, Lynne and Peter, accompanied me on some sight-seeing in Washington and New York. We visited Vice President Richard Nixon in his office, a purely social visit, on June, 24, 1960. (Figure 45.)

Another encounter was December 12,1963, at the time of the annual Westinghouse Christmas party hosted by William Knox at the Wall Street Club in New York. (Figure 46.) 


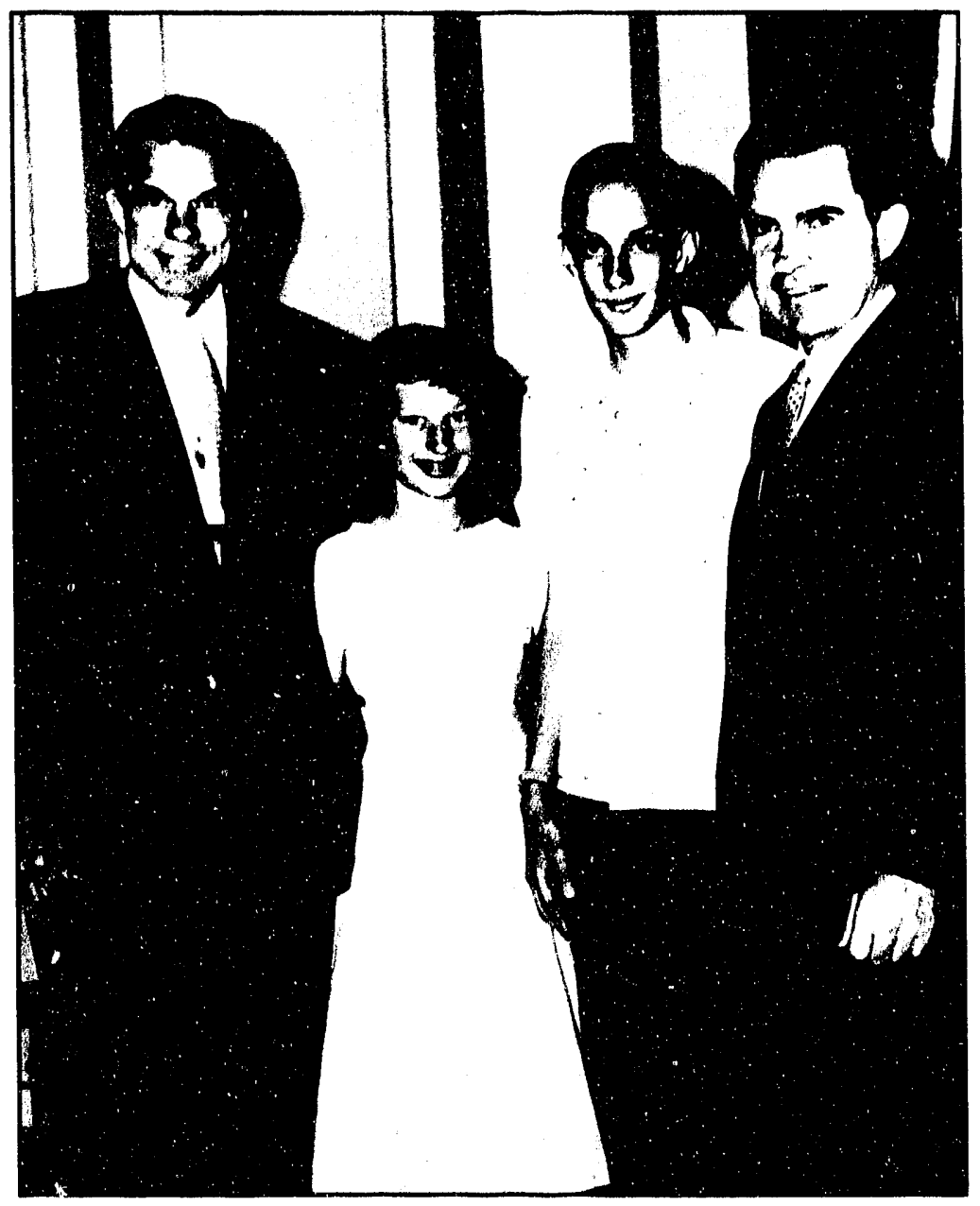

Figure 45.

Seaborg, Lynne Seaborg,

Peter Seaborg, and

Nixon, vice president's

office, Capitol Building,

Washington, D.C., June

24, 1960.

Figure 46.

Nixon, William Martin, and Seaborg at William Knox Christmas luncheon, Wall Street Club, New York,

December 12, 1963.

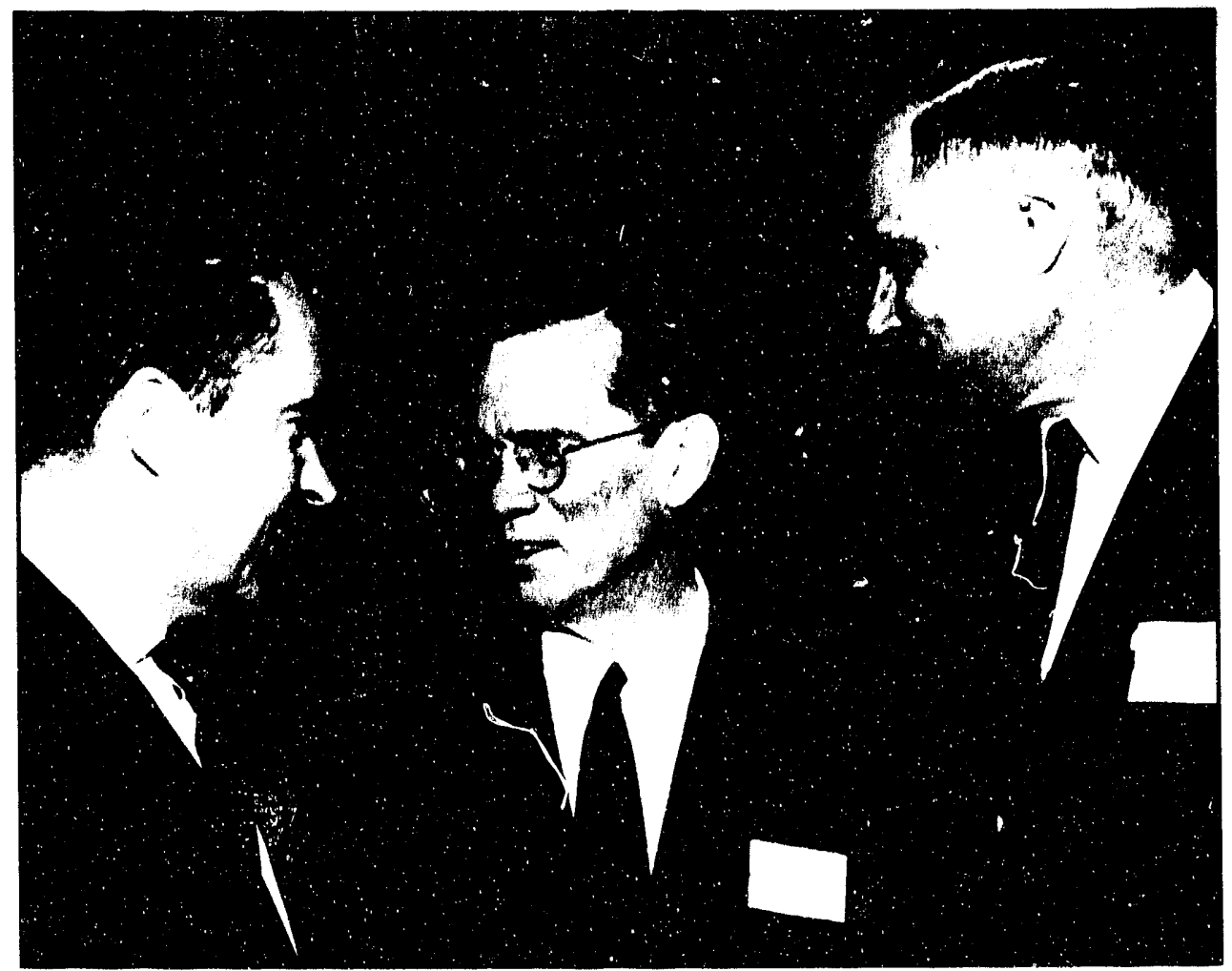


On Sunday, July 23, 1967, I had an interesting breakfast at the Bohemian Grove with Richard Nixon and Ronald Reagan. (Figure 47.):

"I attended a "Gin Fizz" breakfast at the Owl's Nest Camp as Pauley's guest. I sat at the same table as Governor Ronald Reagan, Dick Nixon, Preston Hotchkiss, Rannes, Ed Pauley, Art Linkletter and Herb Hoover, Jr. Harry Wellman, Franklin Murphy, Ed Strong, Dan London, Eddie Carlson were among those present. I discussed my recent South American trip with Nixon. I invited Governor Reagan to visit the Livermore Laboratory.

Pauley spoke to me privately, said he is on the spot because he cannot make a choice between Reagan and Nixon as the guest speaker. He asked if I would serve as the speaker and I agreed. Pauley then introduced me, emphasizing my Watts connection. [I attended David Starr Jordan high school in Watts.] I gave about a 30 minute talk on the peaceful uses of nuclear energy--electric power, desalting, energy complexes, maritime propulsion, nuclear rocket and auxiliary electric power, artificial heart, Plowshare, applications to dating, humanities, criminology, etc. It was very well received and when Reagan was called on he only spoke briefly and humorously saying he knew better than to follow an act like mine. In my question period Reagan asked questions about the use of neutron activation analysis for analysis of baby's disease through fingernail clippings, etc. I admonished the group that California must solve its problems of nuclear power reactor siting and promised to send Herbert Hoover, Ir., a copy of my Commonwealth Club speech. Nixon also spoke briefly and humorously, saying Reagan should become Vice President so as to be elected to the Bohemian Club without a long wait."

After first meeting with his assistant, Robert F. Ellsworth, on January 22, I had my first meeting with President Nixon on January 28, 1969:

"From 3:40 to 4:15 p.m. I had mu first appointment with President Nixon with Lee A. DuBridge, Henry A. Kissinger, Robert F. Ellsworth, and H. R. Haldeman present....

...We discussed... the AEC's peaceful uses of atomic energy program, the problem of high yield underground nuclear testing, and the shutdown of two reactors at Hanford.

The President asked us to enter his office before his preceding appointment had ended, consisting of a group which included Senator Scoop Jackson, Henry Kissinger, General Andrew Goodpaster, and Bryce Harlow. The President introduced us w these people, and as Senator Jackson was leaving, asked him in a semi-joking way what his recommendation on the SST would be. Jackson replied lightly that he had sort of a conflict of interest there and didn't reply directly, but the President reiterated his interest in the SST.

We sat down on the two couches facing each other, in front of the fireplace which had a crackling fire. I sat on the couch next to the 


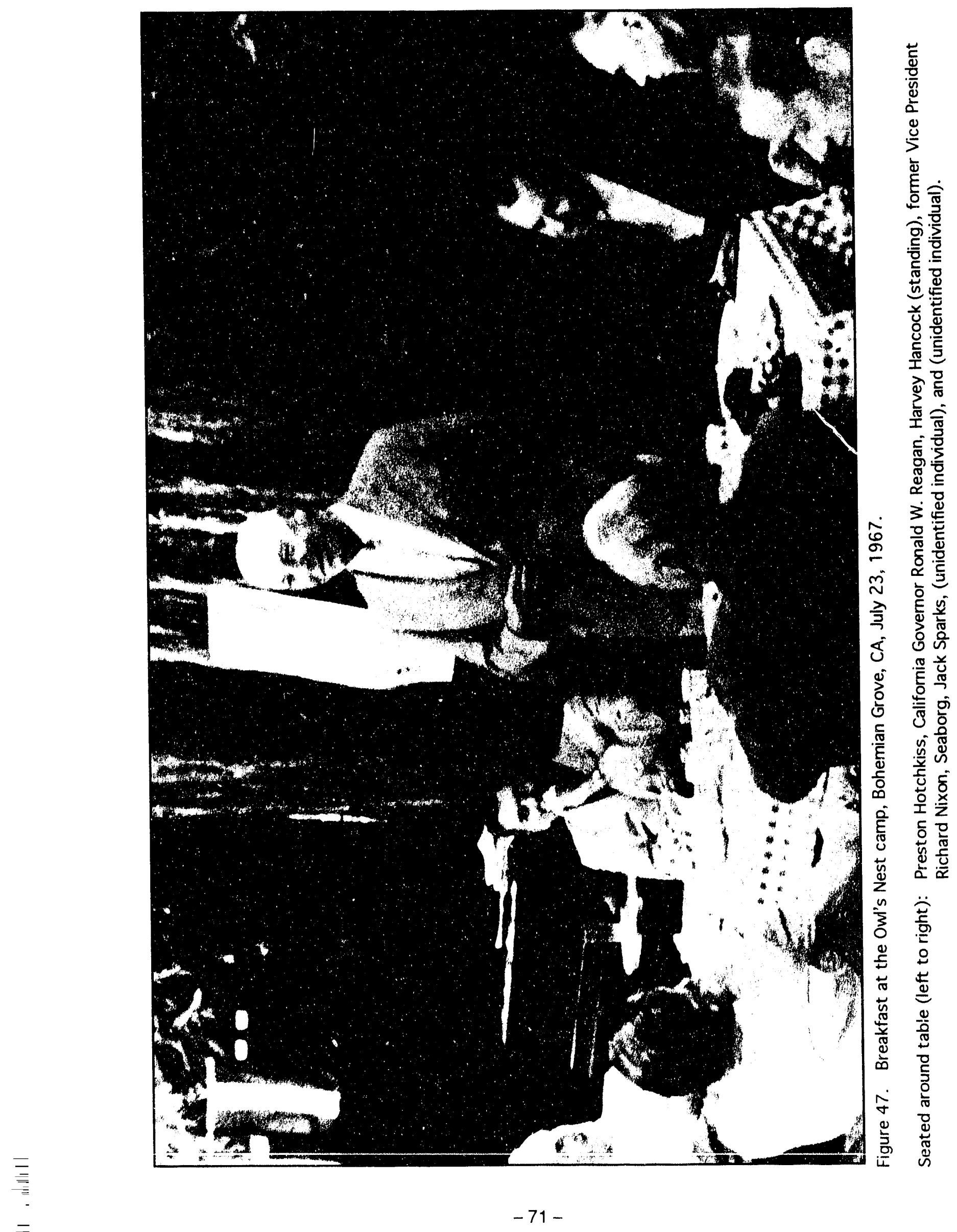


President, while DuBridge, Ellsworth and Kissinger sat on the opposite couch, and Haldeman sat on a chair in between the couches.

The President began by handing me a letter, with an accompanying envelope, saying it was self-explanatory. (This was the letter asking me to stay on as Chairman of the Atomic Energy Commission.) He jokingly said it was a close decision, but that he had the final say....

...The President then raised the question of Plowshare in the peaceful uses of nuclear explosives and said that this is a subject in which he is very interested. He said he wants this to have a high priority in his Administration; in fact, he said he has a special prejudice for this program-the way all people have special quirks and prejudices--and hopes it can go forward expeditiously. He said he has heard of the Australian project and asked whether I could describe this to him.

The President had a two-page memorandum before him, which he glanced at occasionally as we spoke. (I wouldn't be surprised if this might not have been a memorandum written by Ellsworth covering the conversation I had with Ellsworth, Whitehead and Hofgren last Wednesday, January 22.)...

...The President reiterated his interest in the peaceful uses of atomic energy and said he thought this was something that should be accelerated. As he was speaking in broad terms beyond the Plowshare aspect, I asked whether he had in mind power reactor development, and especially breeder development, and he said he did. He thus expanded his request for information on the peaceful uses of atomic energy on a rather broader scale than just the Plowshare program.

The President said he would like to set up some kind of a briefing session in which he and others might be briefed on the peaceful uses of atomic energy. He recalled in this connection the talk I had given at the Bohemian Grove at the breakfast which he attended (this was the talk at the Owl's Nest in July, 1967) and how impressed he was by my description of the great potential in this field. I immediately suggested that he come to our Headquarters in Germantown and meet some of the key staff and be briefed on our program. He said he would like to do this and that the briefing might cover the weapons and national security aspects as well as the peaceful uses aspects of atomic energy. At first he said he might come out in about two months, but then as the conversation continued, he suggested it might be March. When I hinted it might be useful to come even earlier, he said he could possibly do it in February. He asked Haldeman to include the Atomic Energy Commission among the departments and agencies that he was scheduling for visits. He also suggested to Haldeman that Secretary of State Rogers should be included in the briefing at Germantown...

Somebody raised the question whether I should see the press; although I indicated it would probably be best if I left in low key without 
doing this, the President immediately suggested that he would prefer that I meet with the press--that he was making such meetings a part of his mode of operation. He suggested I might indicate that he had asked me to stay on as Chairman, that we had discussed a number of items, especially the peaceful uses of atomic energy. He suggested I indicate his interest in this field, mentioning especially the Plowshare program and the Australian harbor experiment and the power program, such as the breeder reactors. He also suggested I mention that he was going to visit the AEC at Germantown soon in order to be briefed further about the AEC's program.

As the meeting broke up, the President suggested that a photographer come in to take some pictures for the historical record, which was done. (Figure 48.) The President and I recalled our meeting long ago--in January, 1948--at Chattanooga, when we were both in the group of the Ten Outstanding Young Men of 1947, chosen by the U.S. Junior Chamber of Commerce. I said I had a photograph of us in that context ani.' asked whether he would autograph it, and he said he would be glad to do so. I also said I had a picture of him with my kids, taken in June, 1960, and he indicated very cordially that he would be glad to autograph this also.

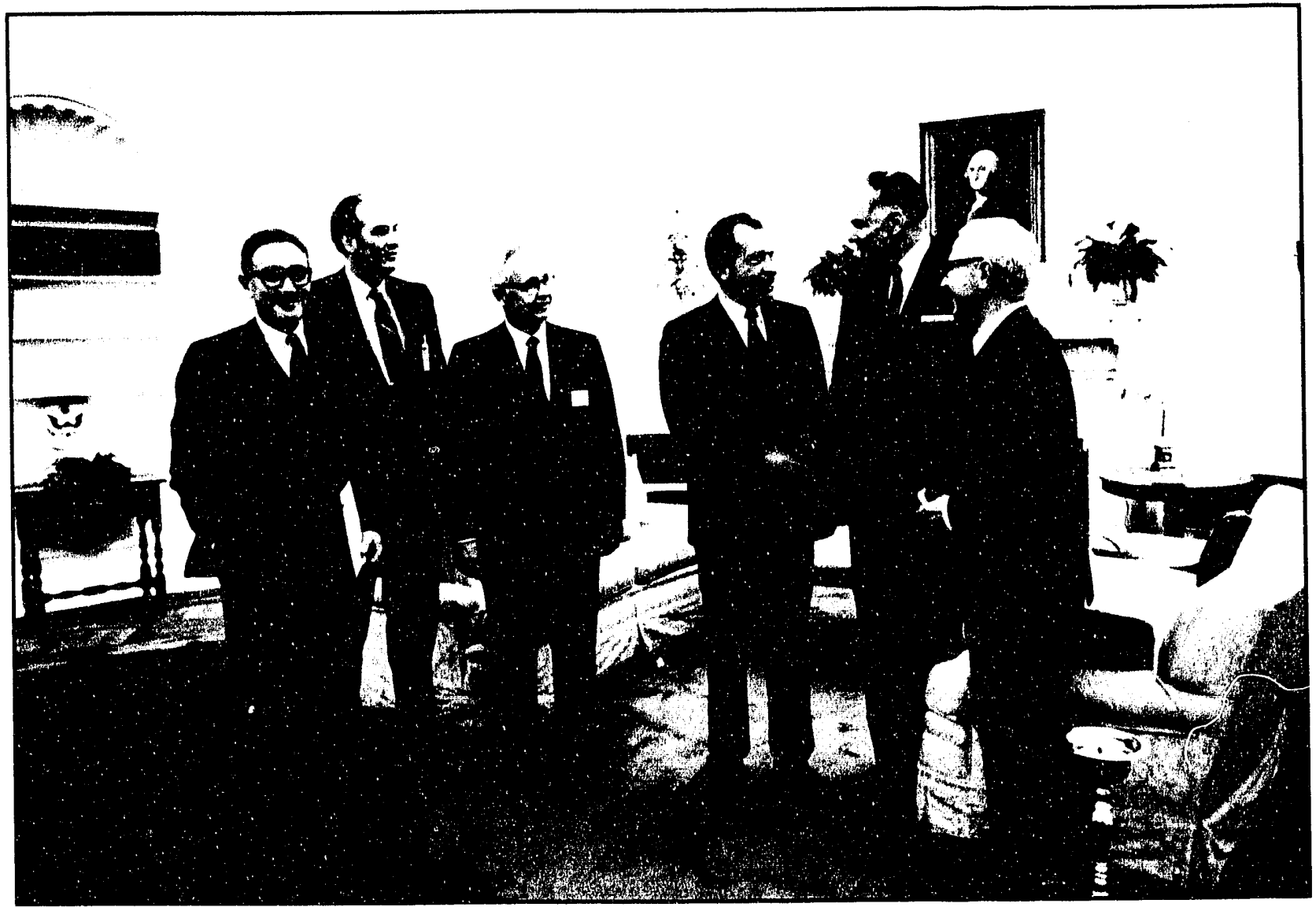

Figure 48. Henry Kissinger, Robert Ellsworth, Patrick Haggerty, Nixon, Seaborg, Lee DuBridge, Oval Office, January 28, 1969. 
After my appointment with the President, Ellsworth took me to the Press Room, where we met Ron Ziegler. We waited for a few minutes outside while Interior Secretary Walter Hickel was finishing his press conference; when he came out, I met him. Ziegler then took me to the packed Press Room to a microphone.

I began by saying that I had just finished meeting with the President and that the President has asked me to tell the press about our conversation. I said we had talked about some national security matters and then had gone on to discuss the AEC's program for the peaceful uses of atomic energy. I said the President had expressed a great interest in this program and that he had especially singled out Plowshare and the power reactor breeder program. I said he has asked that these programs receive adequate attention and be accelerated by the AEC. I said he had mentioned a special interest in the use of nuclear explosives for the building of a harbor in Australia. I also said that the President indicated he intended to visit the AEC in its Germantown Headquarters sometime in February to receive a more thorough briefing on the AEC's program....

...In answer :o a question I was asked, whether the President had asked me to continue as Chairman of the AEC, I indicated that he had. I was asked how long my term is, and I indicated that I voluntarily accepted a short term, which expires in June, 1970. I indicated that my term as Commissioner was determined by law, and that my designation as Chairman was a separate matter, done by the President."

Actually President Nixon's planned visit to the Germantown headquarters of the Atomic Energy Commission never materialized. I soon found that President Nixon's modus operandi differed substantially from those of Presidents Kennedy and Johnson. Rather than report directly to the president, as I had with Kennedy and especially with Johnson, I reported to Nixon through a sequential series of intermediaries. Also, I attended Cabinet meetings and National Security Council meetings only on rare occasions. Nixon also eliminated The Committee of Principals that used to deal with arms control matters in the Eisenhower, Kennedy and Johnson administrations. Science Advisor Lee DuBridge had less and less authority and was soon bypassed on matters that used to be within the province of his predecessors. Although not cut off as completely as DuBridge, I soon found that I was often bypassed in the discussion of arms control matters. There appeared to be an attempt to change, as much as possible, all modes of operation used by previous administrations--as illustrated by the fact that the National Security Action Memoranda (NSAM) issued by Presidents Kennedy and Johnson were replaced by National Security Study Memoranda (NSSM) and National Security Decision Memoranda (NSDM).

Illustrative of my mounting problem was the adnınition I received from President Nixon at an early meeting on arms control matters (April 30, 1969). He asked me to confine my advice to scientific matters and not include matters with political implications: 
"...(President Nixon) recalled that in the case of the Limited Nuclear Test Ban Treaty, he thought it was a close question but decided, on balance, to come out in favor of it. He wasn't sure whether this had been the correct decision and asked me what I thought. I said that I thought the Limited Nuclear Test Ban Treaty had been clearly to the advantage of the United States, to the Soviet Union and to the world. I said that its main benefit had come from its beneficial effect in slowing the tempo of the arms race. Another beneficial effect was in stopping radioactive fallout from atmospheric testing, which, if atmospheric testing had continued unabated, could have reached undesirable levels.

President Nixon then asked my view on the seabed treaty, and I indicated that, on balance, I was in favor of it. I said I thought that it would be a mistake to reverse our position on this at the ENDC now, after we had come out in favor of it. The President indicated that he was most interested in my technical judgment and not my political judgment. (I believe that he was speaking here largely for the benefit of Secretary (of Defense Melvin) Laird and Vice President (Spiro) Agnew who had spoken so definitely against the seabed treaty.) I said that even in confining my judgment to the technical aspects, which is difficult to do in this case, I thought the seabed treaty is to our national advantage...."

The president's comment, that he was more interested in my technical judgment than my political judgment, gave me much to ponder. Apparently, my possession of scientific expertise disqualified me as a source of political judgment. In my role as the Chairman of the Atomic Energy Commission during the Kennedy and Johnson years, I had been an active participant in all aspects of the formulation of arms control policy. President Nixon was telling me that this probably would not continue, and I later found myself in a position of being kept informed, but no longes a participant in the policy deliberations. Science Advisor Lee DuBridge later found himself cut off completely even from information about such celiberations.

In contrast to my successes with President Kennedy, and especially with President Johnson, in appealing budgetary decisions, I had essentially no success with President Nixon. My first, and last, appeal session with President Nixon was held on Tuesday, December 23, 1969:

"I then went to the White House to meet with President Nixon concerning our appeal on the FY 1971 budget. The meeting was held in his oval office and lasted from 4 to 4:30 p.m. Others present were Robert P. Mayo (Director, Bureau of the Budget), James R. Schlesinger (Deputy Director, BOB), John D. Ehrlichman (Assistant to the President for Domestic Affairs) and Henry A. Kissinger (Assistant to the President for National Security Affairs). The President began the meeting at 4 p.m. by saying that this is a tight budget year, particularly due to the need to make up a shortfall of $\$ 2.5$ billion as a result of recent congressional action. He then called on me to present my case. He had some briefing papers before. him which he referred to as I talked. Actually it was pretty much a monologue with my presenting my arguments with very little comment from the others. Mayo and Schlesinger made essentially no comments, 
while Ehrlichman and Kissinger made a couple of comments. The President pretty much limited his remarks to calling for the next item as I proceeded and indicated at the end of each item that he understood the issue, making notes on his legal pad as I talked.

The meeting was brought to a conclusion by the President repeating that this is a tough budget year and that things might be better next year.

He referred again to the $\$ 2.5$ billion shortfall. He indicated, somewhat enigmatically, that the AEC budget had been well prepared and [inferred] well treated. The President thanked me for my presentation and the session came to a close at exactly 4:30 p.m. This budget appeal session was in sharp contrast to my meetings with Presidents Kennedy and Johnson, with their give-and-take discussions. I have the impression that President Nixon had his mind made up before I came and will rule against me on practically all of my appeal items.

A grim-faced Tom Paine [administrator of NASA] was in the waiting room and was asked to enter just as I was leaving."

I learned a few days later, that President Nixon ruled against me on practically every item. I was allowed no more appeal sessions with the president.

Another area where I did not endear myself to President Nixon was my attitude toward his planned ABM Safeguard system. I received word that the White House wanted me to make speeches promoting this program. I believed that such a program would be ineffective, excessively expensive, and dangerously provocative. Nevertheless, I regarded it as my duty, as Chairman of the Atomic Energy Commission, to provide for the testing of any weapons adopted as part of our national program. However, I did not consider it to be my duty to make speeches in favor of a policy being debated by Congress.

Somewhat later, Nixon, to his credit, did change his mind, which led to an ABM treaty. He also negotiated the SALT treaty which, although more limited in scope than some of us wanted, was a move in the right direction.

My forthcoming book, The Atomic Energy Commission Under Nixon: Adjusting to Troubled Times (again, written with the help of Benjamin S. Loeb), describes many of the issues that faced me during my tenure as Chairman of the Atomic Energy Commission under Nixon.

Even the White House dinners were different as illustrated by the one that Helen and I attended on May 6, 1969:

"Helen and I attended a dinner (white tie) at the White House given by President and Mrs. Nixon in honor of the Prime Minister of Australia, John Gorton, and Mrs. Gorton. The arrangements were quite different from those for corresponding events during the Johnson Administration. Upon arrival the guests mingled in the main foyer and 
the Green Room. Then President and Mrs. Nixon and Prime Minister and Mrs. Gorton formed a reception line in the Blue Room and the guests went through the reception line but not in a designated order as had been the custom in the past. When the President introduced me to the Prime Minister, we briefly discussed my visit to Australia and to the nuclear laboratory at Lucas Heights and mentioned the Australian interest in Plowshare projects. The President and party then emerged through the Red Room and went directly to the State Dining Room for dinner.

A new table arrangement was used--a horseshoe with a third long table bisecting the horseshoe (sort of an " $E$ " shaped table). I sat next to Mrs. Marshall Green (he is Assistant Secretary of State for Far Eastern and Asian Affairs) and Mrs. Thomas Moorer (he is Chief of Naval Operations) and near Shelby C. Davis (Ambassador-designate to Switzerland). Helen sat across from me and next to David Packard and Donald Clausen (Congressman from California). Toward the end of the meal we were serenaded by the violins of an Air Force musical group. At the end of the dinner, President Nixon spoke extemporaneously in praise of the historic and fine relationship between the United States and Australia and gave a toast to that relationship, to Australia and to Prime Minister Gorton. Gorton responded in a very eloquent, in fact, impressive manner referring to the huge picture of Lincoln on the wall to his right and drawing an analogy to President Lincoln's and President Nixon's problems with a strong description of the extraordinary relationship between the United States and Australia.

After the dinner, the guests assembled in the Red and Blue Rooms. Helen and I had a rather long talk with Mrs. Gorton and Mrs. Nixon in the Blue Room. Mrs. Gorton told us that she had been raised in Maine, finished her schooling there and then went to Paris, where she met $M r$. Gorton. Since that time she has lived in Australia. I told Mrs. Gorton about the fine nuclear laboratory at Lucas Heights that I had visited and suggested that she might like to visit it sometime. We discussed with Mrs. Nixon the new arrangements under which the dinner was carried out, and we also discussed President Nixon's heavy schedule.

The guests then assembled in the East Room for the entertainment which consisted of a concert by Grant Johannesen, pianist, and his wife Zara Nelsova, violoncellist. Dancing in the main foyer followed the entertainment and Helen and I participated in this for a while prior to our departure."

However, on occasion, President Nixon could be very gracious, as illustrated by the ceremony that took place in his office on February 27, 1970, when, at my suggestion, he conferred Special Atomic Pioneer Awards upon Dr. Vannevar Bush, Dr. James B. Conant, and General Leslie R. Groves:

"I then went to the President's Oval Office in the White House to attend a ceremony for the presentation, by the President, of the Atomic Pioneer Awards to Dr. Vannevar Bush, Dr. James B. Conant and General Leslie R. Groves. Others present for the ceremony were Commissioners 
Ramey and Larson, Drs. John H. Bush and Richard Bush (sons of Vannevar Bush), Mrs. James B. Conant, Mr. and Mrs. James R. Conant (son and daughter-in-law), Mrs. Leslie R. Groves and Brigadier General and Mrs. Richard H. Groves (son and daughter-in-law), Senator John O. Pastore and Congressman Craig Hosmer. Among those helping with the arrangements were Will Kriegsman, Steve Bull, Major Brennan, Bruce Whelihan (White House Press attaché) and John Nidecker (White House congressional liaison). A number of movie and still photographers were present and active during the ceremony.

After we entered the Oval Office I greeted the President and then introduced him, in turn, to Dr. Bush, Dr. Conant and General Groves. I also introduced him to Commissioners Ramey and Larson who followed the awardees into the room. The President also greeted Senator Pastore and Congressman Hosmer.

The award ceremony took place in front of the President's desk. I stood at the President's right and the awardees at his left. I made a few introductory remarks about the achievements that had led to these awards and emphasized that they were the first and only Atomic Pioneer Awards, which could not be duplicated due to the unique nature of the recipients. The President took up this theme in his initial remarks, emphasizing that the awards were unique and especially distinguished. I read the citation for Dr. Bush following which the President presented him with a medal. The same sequence was followed for the presentations to Dr. Conant and General Groves.

At the conclusion of the presentations, I remarked to the President that these three distinguished gentlemen had been in the Oval Room many times before to confer with his predecessors, notably Presidents Roosevelt and Truman. This led the President to inquire of the recipients whether they at any time had felt any doubts about the successful outcome of their endeavors to produce the nuclear weapons. The general tenor of their responses was that they had entertained such doubts and this led to each of them reminiscing briefly. Dr. Bush recalled the story of an official who, having been queried about the possibility of failure of the initial atomic bomb test, responded that he had worried lest the calculations could have been wrong, leading to excess energy release which would have caused trouble, but he had been just as worried that the test might be a complete failure which would have caused even more trouble.

President Nixon encouraged General Groves to reminisce in $r$ similar fashion, whereupon Groves recalled that General Madigan had rented a double house near the Capitol at about the time of the end of the war and had invited General Groves to move into the other half because it was evident that he would be testifying continuously and indefinitely before Congress in defense of the project.

The President then turned to Dr. Conant, who recalled that Under Secretary of War Patterson had asked General Somervell to make an investigation as to where all the money was going in the Manhattan 
project and to try to determine its chances for success. Somernell was given only a few minutes to make his report to the busy Patterson but he said this would be sufficient time because his report would be simple-should the project be a success, there would be no need for an investigation as the war would end, and, should it be a failure, there would be no need to investigate anything else.

The President then called on Senator Pastore to say a few words. Pastore spoke of the important contribution to free world security that the three recipients had made and the debt that we all owe them.

The President then called on Congressman Hosmer, who expressed the regrets of Congressman Holifield who couldn't be present and spoke in laudatory terms concerning the contributions of the three recipients.

The President then had pictures taken, individually with each of the three recipients and their families, and with Commissioners Ramey, Larson and me and the three recipients. (Figure 49.)

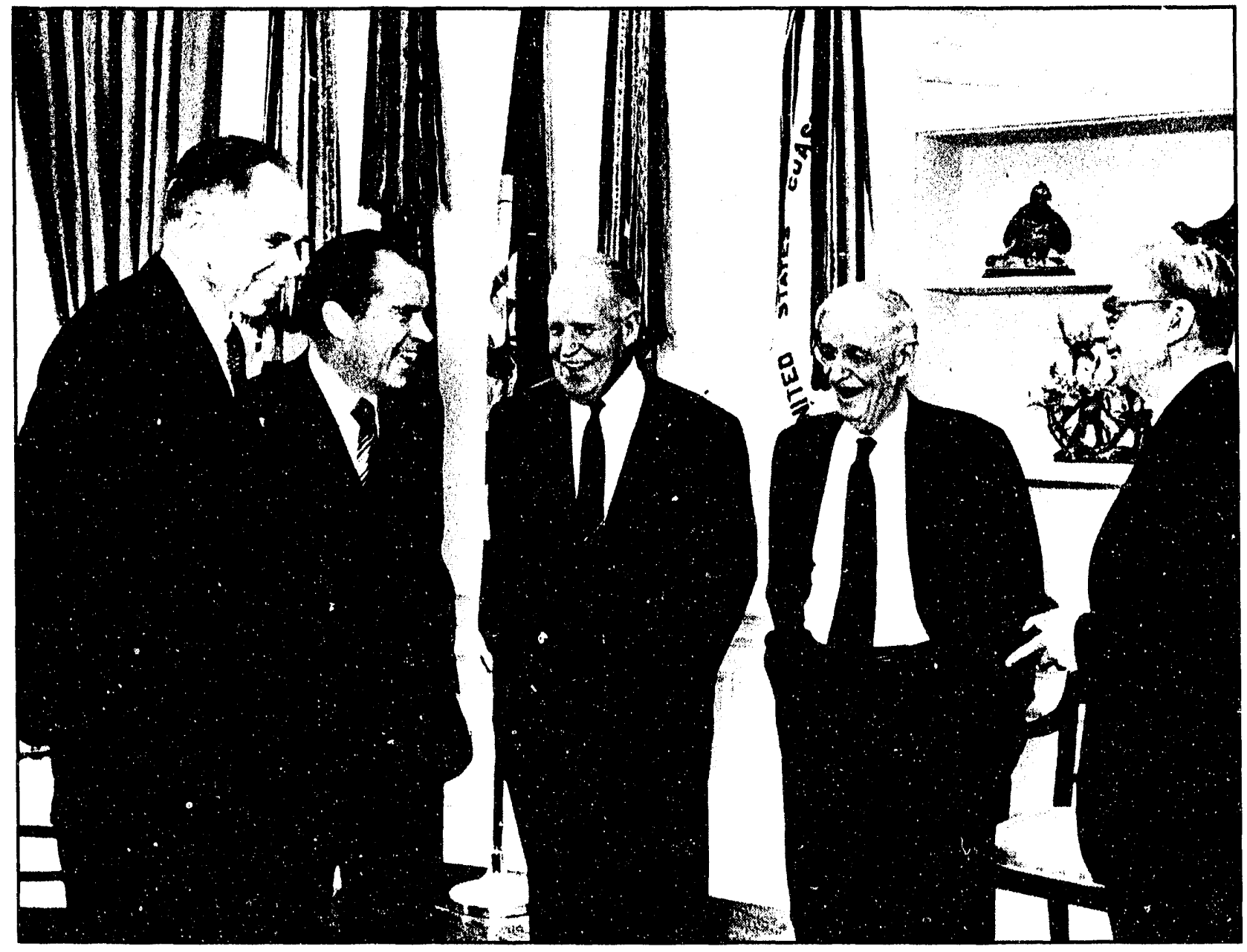

Figure 49. The Atomic Pioneer awards ceremony, Oval Office, White House, February 27, 1970. Left to right: Seaborg, Nixon, General Leslie R. Groves, Vannevar Bush, and James B. Conant. 
The President then showed us some of the items in his office, singling out the tonged device which the Apollo 12 astronauts had used to pick up rocks on the moon and which they had mistake ly taken with them back to earth. The President said that he had kept them out of trouble by taking the device from them and displaying it in his office.

The President very graciously said individual goodbyes to those present. He was very relaxed, gracious and friendly throughout the whole ceremony."

The timing of this award was very fortunate for General Groves; he died just a few months later, on July 13, 1970.

Since I had requested from Presiderit Johnson, at the expiration of my term as AEC Chairman in 1968, a reappointment for a toyo-year term, this term came to an end on August 1, 1970. Encouraged by strong endorsements by industrial and other leaders in the atomic energy community, President Nixon reappointed me as Chairman of the Atomic Energy Commission (Figure 50.) with the understanding that I intended to leave the position after one year, in the summer of 1971.

Lee DuBridge's position as Science Advisor to President Nixon and Director of the Office of Science and Technology became untenable and led to his resignation in 1970. President Nixon preferred a scientist with an industrial background as Wu'bridge's replacement and therefore, he appointed Edward E. David, tho had been serving as the Executive Director of Research for the Bell Telephone Laboratories in Murray Hill, New Jersey. I found that I was able to establish a reasonably satisfactorily working arrangement with Ed David.

President $\Gamma:$ :xon initiated plans for the reorganization of the Executive Branch of the federal government which threatened the very existence of the A tomic Energy Commission. For this, he appointed Roy Ash (President of Litton 
Industries) to serve as Chairman of the President's Advisory Council on Executive Organization. The plans, as they developed, would have had a disastrous effect on the Atomic Energy Commission. The AEC program of civilian nuclear power would be placed in a new Department of Natural Resources. The regulatory function of the AEC would be placed into something like an Energy Regulatory Agency. Still further steps would involve taking the weapons function and putting it into the Department of Defense, the research function into the National Science Foundation, and so forth.

This reorganization could have been implemented only as a result of congressional action. I participated in a series of meetings with the Ash Council and its subcommittees and was able, step-by-step, to convince the members of the Council and the decision-making members of the Nixon Administration that dismemberment of the Atomic Energy Commission was both unwise and, probably, not feasible. I persisted in making the recommendation that a more sensible reorganization would be to place all of the governmental energy functions in a single agency that might be built around the Atomic Energy Commission. In this defensive stand, I had the support of many of my friends in the Congress, including especially the members of the Joint Committee on Atomic Energy. The plans of the Ash Council never came to fruition. A few years later, in January, 1975, a reorganization was effected, which, incidentally, was along the lines that I had advocated. The centralized energy agency was created in the form of the Energy Research and Development Agency (ERDA) and the regulatory function of the AEC was placed in a new Nuclear Regulatory Council (NRC). A couple of years later, effective on October 1, 1977, the ERDA was expanded with a wider rang of functions into the Department of Energy.

Jn April 13, 1971, I was asked to brief the President's Cabinet on the subject of breeder reactors:

"I went to a meeting of the President's Cabinet in the Cabinet Room of the White House, which began a covple of minutes after 8 a.m. and ran until 9:20 a.m. Present were: the President, DOD Secretary Melvin Laird, Post Master General Winton Blount, Agriculture Secretary Clifford Hardin, HUD Secretary George Romney, Commerce Secretary Maurice Stans, Transportation Secretary John Volpe, State Under Secretary John Irwin, OMB Director George Shultz, Counselor Bob Finch, Congressman Chet Holifield, Congressman John Anderson, Senator John Pastore, Senator Howard Baker, and I, around the main table. Also present were: Cap Weinberger, Peter Flanigan, Ambassador David Kennedy, Paul McCracken, John Ehrlichman, Herb Klein, Ron Ziegler, Ed David, Dave Freeman, William Ruckelshaus (EPA), Abe Lincoln, Clark MacGregor, John Whitaker, Hollis Dole (Interior), Will Kriegsman, Richard Kleindienst (Deputy Attorney General), Milt Shaw, and others.

The purpose of the meeting was to discuss the future of the fast breeder reactor, and it may well be recorded as a very historic meeting. The idea originatea as a result of the discussion that Holifield haa with the President on an airplane trip to California. Although the primary reason, based on that discussion, is a consideration of the fast breeder Ithis is 
Holifield's point of view], the President also has in mind his reorganization plan and the possibility of enlisting Holifield's support.

When the President came into the room and after we took our seats, he immediately opened the meeting. (I had a designated seat at the end of the table to the left of the President and the Congressional members sat at the opposite end of the table to the right of the President.) The President referred to his discussion with Holifield on the airplane trip to California and described Holifield's feeling that the breeder reactor should have a top priority during the next decade. He also referred to the "early morning" meeting that he atiended at the Bohemian Grove at which I had held the group in the camp spellbound with my talk on the peaceful uses of atomic energy. He recalled the Atoms for Peace program had been launched in 1953 by President Eisenhower. He then called on me to make my presentation.

I opened with a reference to the Bohemian Grove gathering and added that since President Nixon and Governor Ronald Reagan were both present, the host had solved the problem of who should make some remarks by calling on me to speak on the peaceful uses of atomic energy. I indicated that the Atoms for Peace program had been very successful in giving the United States an entree into many countries of the world by helping them and had also contributed to diminishing the threat of nuclear proliferation. I said that 25 countries are involved now in the development of nuclear power for the production of electricity....

...I then went on to my discussion of the fast breeder reactor. I explained briefly the role of plutonium in serving as a catalyst to make it possible to burn non-fissionable, fertile $U-238$, and emphasized that in this manner there would be enough uranium to serve as a fuel for thousands of years. I described the sodium metal cooling aspects and indicated that the liquid metal-cooled fast breeder reactor, which I emphasized is becoming widely known as the LMFBR, is our main line program. I said this is also the case in the Soviet Union, England, France, Japan, and other countries. I described the advantages of the breeder, namely that it utilizes the uranium some thirty-fold more efficiently, that it will be more economic than even water-cooled reactors, that it will have less radioactive effluents because it is hermetically sealed, and it will discharge less waste heat....

...I indicated that we are creating advisory committees to help us generally and to help raise funds and these include such members as Jack Horton (Chairman of Southern California Edison), Shermer Sibley (President of Pacific Gas \& Electric), Red Wagner (Chairman, TVA), Mr. Parker (Executive Vice President, Duke Power Company), and others. I emphasized that both private and publicly-owned utilities are represented. I said that the problem is to come up with the funding required to build this first demonstration reactor. I then mentioned the backup reactors: the molten salt reactor at Senator Baker's laboratory, the light water breeder reactor being developed by Admiral Rickover (botin of which use slow neutrons and thorium as a fuel) and the helium gas-cooled altcrnate 
to the liquid metal-cooled fast breeder reactor. I then indicated that Milt Shaw was present to help answer other questions and said that I would rest my presentation at that point.

The President then called on Holifield, who emphasized the importance of electrical energy in cleaning up our environment, keeping our industrial economy going, etc., and emphasized the importance of the fast breeder. He indicated that this should be the number one priority of the 1970's and that it is much more important to spend $\$ 2$ billion- $\$ 3$ billion this way than it had been to spend $\$ 50$ billion to reach the moon.

The President then called on Senator Pastore who also indicated his strong support for the fast breeder reactor. He said he thought that all 18 members of the JCAE supported this reactor. He said he thought we couldn't over-estimate the importance to our future to have an adequate electrical energy source.

The President asked me how other countries are coming along on the breeder reactor, and I said that they are ahead of us. I indicated that England is building a demonstration reactor (at Dounreay, Scotland, which I visited last September) of 250,000 kilowatt capacity, to be put into operation next year, and France is building a 250,000 kilowatt demonstration plant to come into operation in 1973. I indicated that the Soviet Union is well along on a 350,000 kilowatt demonstration reactor and is aiso building a 600,000 kilowatt demonstration reactor. All of these will be of the liquid metal-cooled fast breeder type. The President asked me how it happened that these countries are ahead of us, and I indicated that they are only ahead with the construction of their first demonstration reactors and this, because they started construction before we did, but that if we speed up our program with the 1980 objective, we would get there before these others. In answer to another question by the President, I described the objective as a one million kilowatt, reasonably economical, and reasonably low doubling time reactor. I explained that a fast breeder reactor forms about 1.4 kilograms of plutonium in the blanket for each kilogram of plutonium burned in the core, thus leading to a doubling time of about ten years.

The President then called on Senator Howard Baker who strongly supported the need for electric power via the fast breeder reactor and mentioned the possibilities of fusion. The President called on Congressman John Anderson who also strongly supported the fast breeder reactor. Both emphasized the need for a speedup in the program.

At one stage the President expressed the opinion that an increased effort in the breeder reactor might result in increased employment for some of the scientists and engineers who have become unemployed recently....

... The question of fusion came up, and I indicated that while research support for this should be increased, it is a problem of such complexity that we wouldn't have a practical plant operating before the year 2000 . I said, houne?or, there are n number of people who tolk with 
scientists (not so much scientists themselves) who feel that we should skip the fast breeder and go directly to fusion power. I indicated that this is totally unrealistic.

Irwin also indicated strong support for the nuclear power and the breeder approach to the generation of electric power....

...In summing up the meeting, the President indicated that he would discuss this further within the Administration and would try to come up with some kind of a decision soon."

This optimistic outlook for the development of the breeder reactor in the United States did not materialize and this program was later terminated. (I should say, I was overly optimistic.) Although conventional nuclear power has grown to a point where this form of energy produces about $20 \%$ of the electricity in the United States, further growth in the total has virtually stopped, due a combination of low load growth, environmentalist pressure, regulatory uncertainty, and increased costs.

I had many contacts with Vice President Spiro Agnew during meetings of the Space Council (and the Space Task Group) and the Marine Council, which I served as a member and he served as chairman. From my journal, I recount my attendance at the first meeting of the National Aeronautics and Space Council held under the chairmanship of Vice President Spiro Agnew on October 28, 1969:

"From 2:35 to 3:25 p.m. I attended a meeting of the National Aeronautics and Space Council in Room 170 of the Executive Office Building. Present, at the table, were: Vice President Agnew, William A. Anders (Executive Secretary), U. Alexis Johnson (State), Dr. Lee A. DuBridge (OST), Dr. Robert C. Seamans, Jr. (Air Force), Dr. Thomas O. Paine (NASA), James $r$. Schlesinger (BOB) and I. (Figure 51.) Others present were: Herman Pollack (State), I. Nevin Palley (DOD), Milton W. Rosen (NASA), Milton Klein (AEC), C. Stanley Blair and Jerome B. Wolff (Vice President's Office), Russell W. Hale, Winfred E. Berg, William E. Thurmon and Alfred C. Barbee (NASC Staff).

Vice President Agnew, serving as chairman, opened the meeting with a short statement, recognizing that this was the first meeting of the reorganized National Aeronautics and Space Council (NASC) and suggesting that it has an important role to play. He said that it will be necessary to find the proper balance between attention to astronautics and aeronautics. He also mentioned that the fate of the space Task Group report and its recommendations has not yet been determined. He then called on Anders.

Anders described the changes in the NASC that have taken place (mentioning that I am the only original members still present), the objectives of the NASC Act of 1958, and the objectives outlined in the Space Task Group report. He also discussed his plans for manning the staff of the NASC, saying that he is asking BOB for six more people in the 


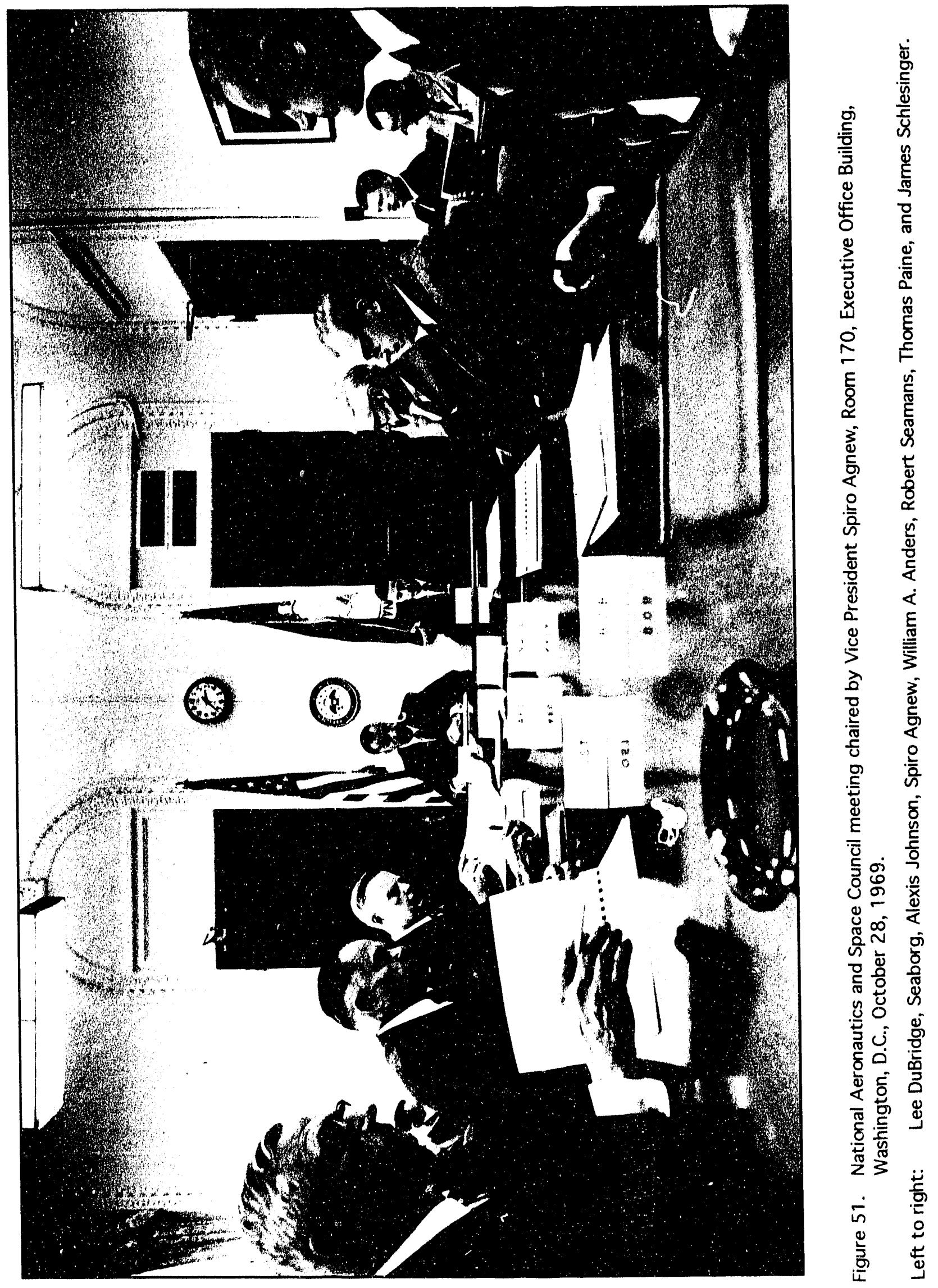


1971 budget and has asked, and received, the loan of a number of people from $D O D, N A S A, A E C$, etc.

Agnew complimented Anders for his fine report and for the progress that is being made under his leadership. He then called on him to describe items for future NASC meeting agenda. Anders mentioned the following items: (1) Develop activities of the Council and staff in relation in Space Task Group recommendations; (2) Survey of aeronautical policy from a national viewpoint; (3) Define policy implications of navigational satellite systems for civil, military, and international use; (4) Develop recommendations for national and international policy for the operational use of earth resource satellite programs; (5) Assist in definition of government's responsibility in development of commercial domestic satellite systems; (6) Provide recommendation with respect to national policy on international cooperation in both aeronautics and space; and (7) Develop mechanism to provide recognition of non-Council member agencies having responsibilities for or affected by aeronautical and space activities.

Agnew then called on Johnson for any comments; Johnson emphasized the importance of items 6 and 7 , especially the international aspects. In response to a request for my comments, I made the point that item 1, the development of activities of the Council and staff in relation to the Space Task Group recommendations, is a broad assignment. DuBridge commented on the important role of international cooperation, both bilaterally and multilaterally. He said that there is a sort of crisis in the science component of the program and that some scientists have even criticized the STG report. He said it is clear that there is a public relations job to do. He also emphasized the need to get academic scientists to come to work in the space program to help bridge the gap. Schlesinger emphasized the budgetary aspects and said that the President has suggested budget sharing in the international program. Paine emphasized the international flavor of all the agenda items.

I asked Paine whether the Soviets actually have put a lunar landing program at very low priority as recent newspaper publicity has stated. Paine replied that intelligence reports show that the Soviets definitely do have a moon program and that recently statements by Mstislav Keldysh, who often shoots from the hip, were probably meant as a cover for some of their failures.

Agnew finally called on Seamans for his comments, arid tic emphasized the importance of the space shuttle and the satellite's.

Agnew then drew the meeting to a close. He said that today's meeting only served as a testing ground for future meetings which would be devoted to more specific topics."

Agnew resigned from his vice presidency in October, 1973, and was immediately replaced by Gerald Ford. 
I have known Richard Nixon, as a U.S. Congressman, U.S. Senator, vice president, and president for more than forty years, Clearly, he is a man with a complex personality and many contradictions--alternately friendly and harsh. Overall, I would, nevertheless, regard him as a friend. I am pleased that he has consented to serve as co-chairman of the banquet in honor of my 80 th birthday to be held in the Palace Hotel in San Francisco on November 9, 1992.

\section{Gerald Rudolph Ford, 卢.}

My contacts with Gerald Ford started during the period in the 1960's when he served as U.S. Congressman from Michigan, including his service as Minority Leader of the House of Representatives, at the time of his vice presidency and after his presidency. Helen and I met Gerald and Betty Ford at numerous dinners and other social functions during our stay in Washington. I recall that on one occasion, the four of us--Gerald, Betty, Helen and I--had a very enjoyable dinner together, at the Madison Hotel, enlivened by pleasant conversation sparked by our mutual interest in athletics.

On one memorable occasion at the famous Annual Gridiron Club Dinner held on March 20,1965, at the Statler Hilton Hotel, Jerry and I were seated at the head table, and it was apparent that each of us was very restless. Upon comparing notes, we learned that we were both anxious about the NCAA basketball final which was being played between UCLA, my alma mater, and the University of Michigan, Jerry's alma mater. We decided to steal away from the banquet and go to an upstairs room which had a TV set and where we were joined by Michigan Governor George Romney. Romney, and especially Ford, agonized as it became increasingly apparent that the Michigan team was no match for the UCLA team, which won by a score of $91-80$. I did my best to console them but, of course, I was obviously happy that my alma mater had won. We returned to the head table of the banquet, which was still in progress and where no one showed any sign of having missed us during our absence.

On April 25, 1974, I had the privilege of introducing Vice President Gerald R. Ford for his talk at a conference sponsored by the World Future Society in the International Ballroom Center of the Washington Hilton Hotel. (Figure 52.) He spoke on the energy problem, a central issue at that time. Ford had been appointed to the position of vice president the preceding October and would assume the presidency of the United States a few months later (in August) upon the resignation of President Nixon. During my conversation with Jerry Ford I suggested that the United States should develop as national policy an "energy budget" and then proceed with a program to produce the needed energy to satisfy that budget.

When Gerald Ford became president, he appointed Nelson Rockefeller to the position of vice president. During my tenure as Chairman of the Atomic Energy Commission I met Rockefeller on numerous occasions when he was the Governor of New York. Earlier, during my chancellorship of the Berkeley 
Figure 52.

(right)

Seaborg introducing Vice President Gerald

R. Ford at World

Future Society

conference,

Washington Hilton

Hotel, Washington,

D.C., April 25, 1974.
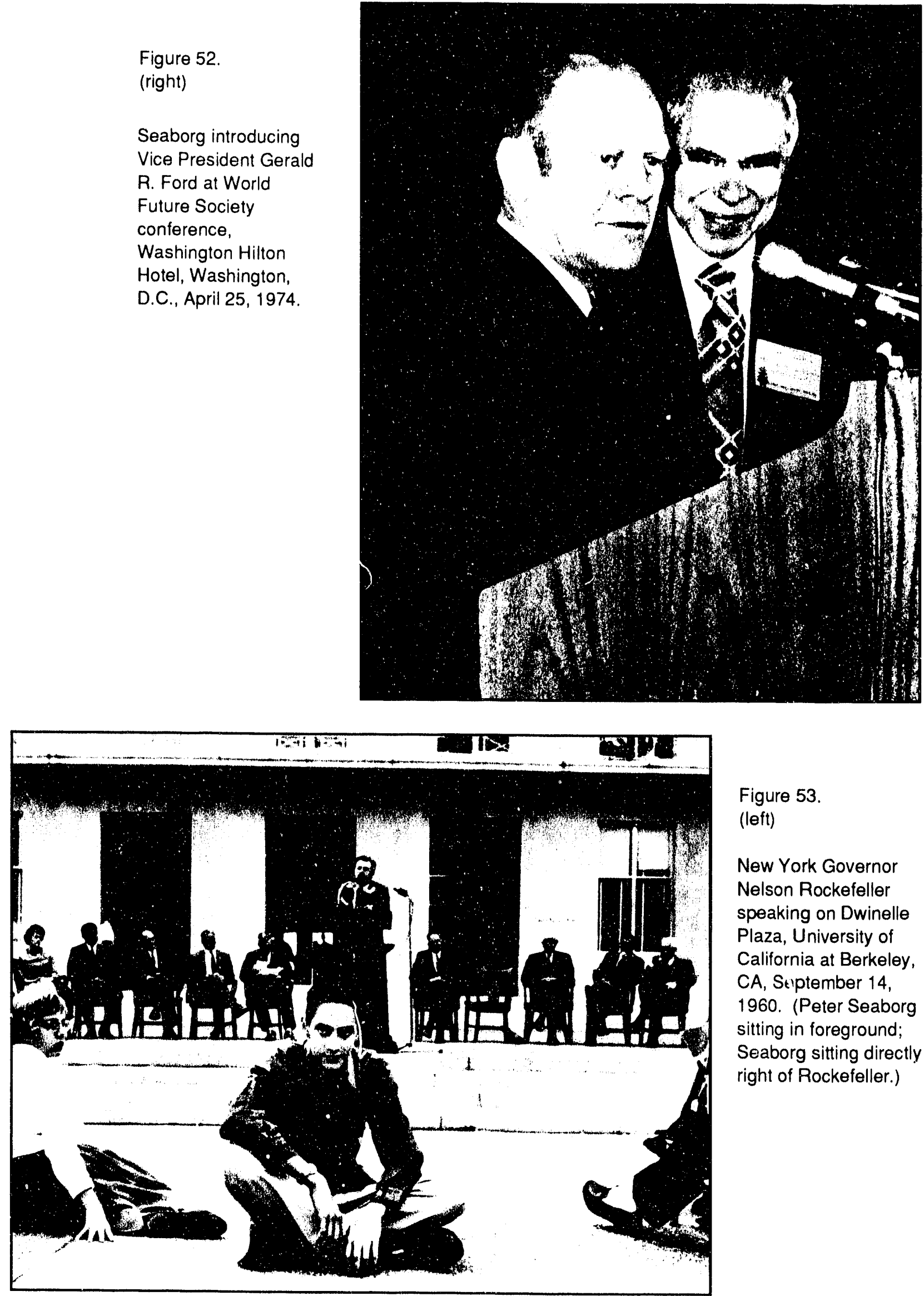

Figure 53.

(left)

New York Governor

Nelson Rockefeller

speaking on Dwinelle

Plaza, University of

California at Berkeley, CA, Stiptember 14, 1960. (Peter Seaborg sitting in foreground; Seaborg sitting directly right of Rockefeller.) 
campus of the University of California, on September 14, 1960, I presented him (Figure 53.) as a supporter of the Republican presidential ticket (Richard M. Nixon and Henry Cabot Lodge):

"Rockefeller gave a speech in Dwinelle Plaza about liberty, freedom, protection of the individual's rights and how the Republican Party and Richard Nixon would uphold these policies. He emphasized the danger of the Communist ideology. He said that he disagreed with their concept of the individual "as a tool of the state with no human dignity, and the loss of the capacity for independent thought and spiritual realization." He advocated the joining of countries in larger entities to protect the freedom of the individual to develop intellectually, spiritually and materially. He said that the biggest problem facing the U.S. is the "need for excellent leadership," that the major problem lies in the international challenge "for freedom to be everywhere in the world."

He answered questions from the audience following his speech. He outlined the differences between Democrats and Republicans, saying that they are different because of their quest for civil rights. When asked about the activities of the House Committee on Un-American Activities, he answered "Americans must face the fact there is a place for this kind of committee." Segments of the audience booed at this remark, but he commented that there were times that the kind of investigation of the committee was not good.

On Red China, he said that some kind of recognition must be made of Red China activities in Tibet, Laos and Vietnam."

On a more personal level, I remember meeting Rockefeller on November 25, 1963, at President Kennedy's funeral:

"At noon I attended President Kennedy's funeral at St. Matthew's Cathedral. After the funeral I was joined by Pete, Dave, Steve and Eric in front of the Cathedral and we were driven in the funeral procession by Jim Haddow to Arlington National Ceremony where we witnessed the burial service.

The kids met New York Governor Nelson Rockefeller, Michigan Governor George Romney, John Glenn, Adlai Stevenson, Soviet Ambassador Anatoli Dobrynin, Minnesota Senator Eugene McCarthy, Speaker of the House John McCormack, U Thant, Ralph Bunche, California Congressman Jeffrey Cohelan and others.

Television and radio continued all-day programs about President Kennedy. People at the Cathedral, the cemetery and lining the way en route all displayed great emotion. The television and radio programs for our country and those all over the world (except China) reflect the tremendous impact of President Kennedy's cieath on peoples' feelings. Our entire family share this feeling of tremendous loss--even Dianne seems to feel it." 
What made this encounter with Nelson Rockefeller so memorable was his friendly act of carrying my nine-year-old son Eric on his shoulders to enable Eric to have a good view of the proceedings.

I had the pleasure of a number of encounters with Gerald Ford following the days of his presidency. On one particularly noteworthy occasion, Helen and I attended the dinner tribute to Admiral Hyman G. Rickover held on February 28, 1983, which was also attended by Presidents Richard M. Nixon and Jimmy Carter. (Figure 54.)

"Helen and I changed into our formal clothes and took a taxi to the Sheraton Washington Hotel to attend the dinner of tribute to Admiral Hyman G. Rickover. We attended the reception where we talked to Chet Holifield and others.

At about 8 p.m. we went to the ballroom for dinner and sat at Table 5 with Dr. and Mrs. James Schlesinger, Mr. and Mrs. Yoshio Okawara (Japanese Ambassador the United States), Mr. and Mrs. Bob Wilson (former U.S. Representative from California) and two others.

I visited some of the other tables and talked to Al Haig (about the need to upgrade the White House on arms limitation measures), Ed Teller, and others. Seated at the head table to the right of the speaker's lectern, left to right (as we saw them), (were) Admiral Rickover, ex-presidents Richard Nixon, Gerald Ford, Jimmy Carter and Joann DiGennaro. To the left of the lectern were Senators Scoop Jackson, John Warner, Strom Thurmond and Mrs. Rickover.

After dinner Joann DiGennaro opened the program by introducing the members of the Board of Directors of the Rickover Foundation, both those present (who acknowledged their presence by standing) and those who were absent. Senator Jackson made some remarks about Rickover and then introduced President Jimmy Carter, who spoke in a humorous way about how he had worked for Rickover both before and after he became President. (Both used prepared texts, with numerous interpolations.) Senator Warner then spoke about Rickover and introduced President Gerald Ford, who also spoke humorously about Rickover's having outranked in the Navy all of the three ex-presidents present that evening. (Again both used prepared texts, with interpolations.) Senator Strom Thurmond spoke about Rickover and introduced President Richard Nixon, who spoke about three personal encounters with Rickover, including two on the occasion of his visit to the Soviet Union in 1959 at the time of his famous kitchen debate with Khrushchev. Thurmond spoke largely extemporaneously, but very clumsily, with each successive thought even worse than the preceding one; he indicated that Nixon's presidency was not all bad, and that he did some good things in foreign affairs (opening the People's Republic of China), economic policy, etc. Nixon spoke extemporaneously without notes.

Admiral Rickover then responded with a prepared talk (w hich he didn't read very well) that recounted a number of incidents in his life as a 


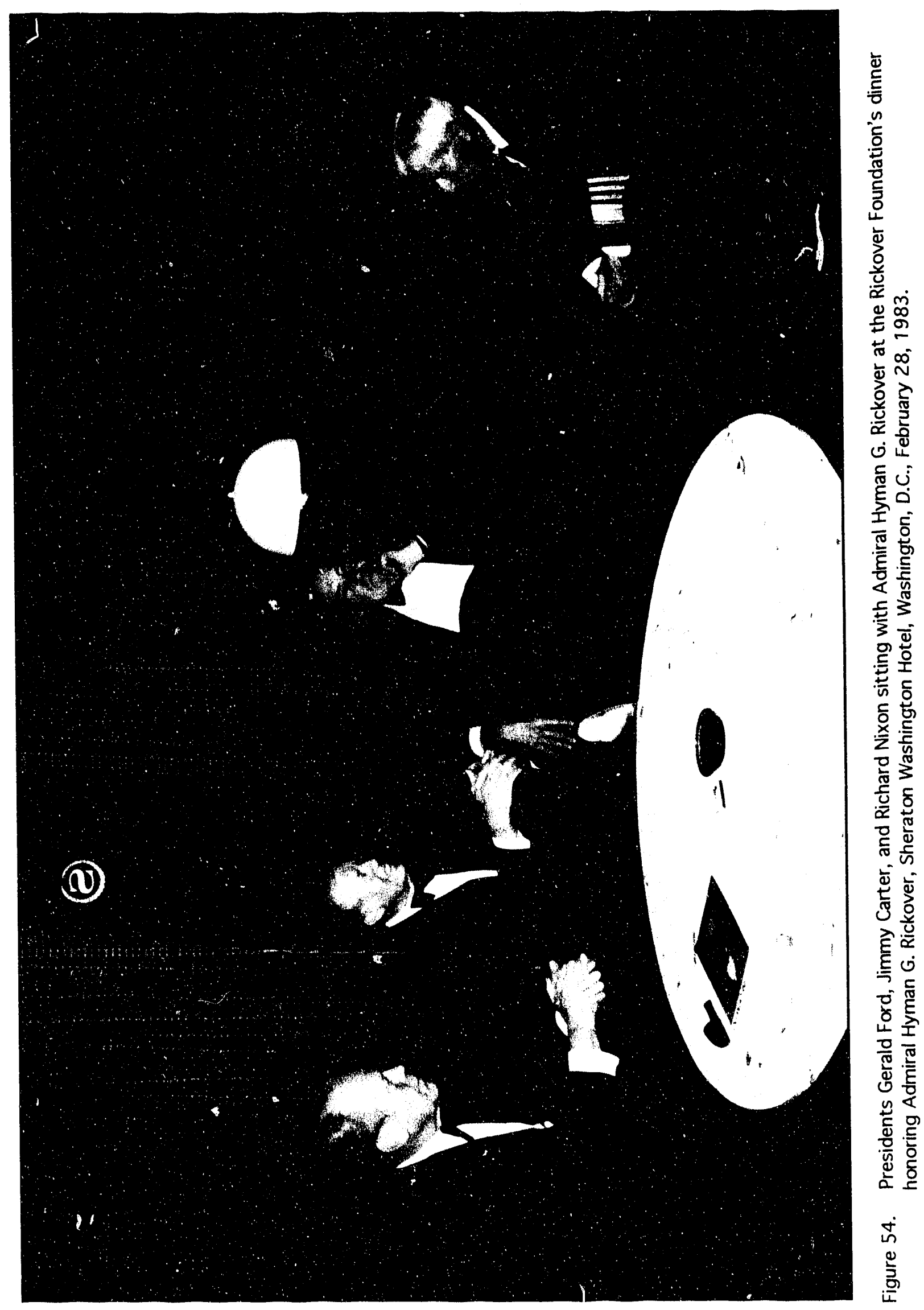


Polish emigrant to the United States. (He and his mother and older sister left Poland under duress when he was four years old and they had much trouble entering the U.S. through Ellis Island.) Congressman Bennett then made some remarks announcing on behalf of the Secretary of Navy that a nuclear submarine is going to be named after Hyman G. Rickover. A surprise, huge birthday cake was then wheeled on the stage. Nixon played "Happy Birthday to You" on the piano which was on stage and then played "God Bless America." The three ex-presidents then joined Rickover at the birthday cake, waving to the audience of about 500 diners, after which the head table guests left the stage through a back curtain."

As Helen and I were leaving the ballroom, the popular TV commentator Martin Agronsky remarked to us that he had thought he would never be in a position to feel sorry for Richard Nixon (as he was that night with respect to Strom Thurmond's unflattering introduction of Nixon).

I met First Lady Betty Ford on a number of occasions. One of the last times I saw her again was when she received a distinguished volunteer service award at the American Academy of Achievement's Annui? Banquet of the Golden Plate dinner in Denver, Colorado on June 29, 1985. (Figure 55.)

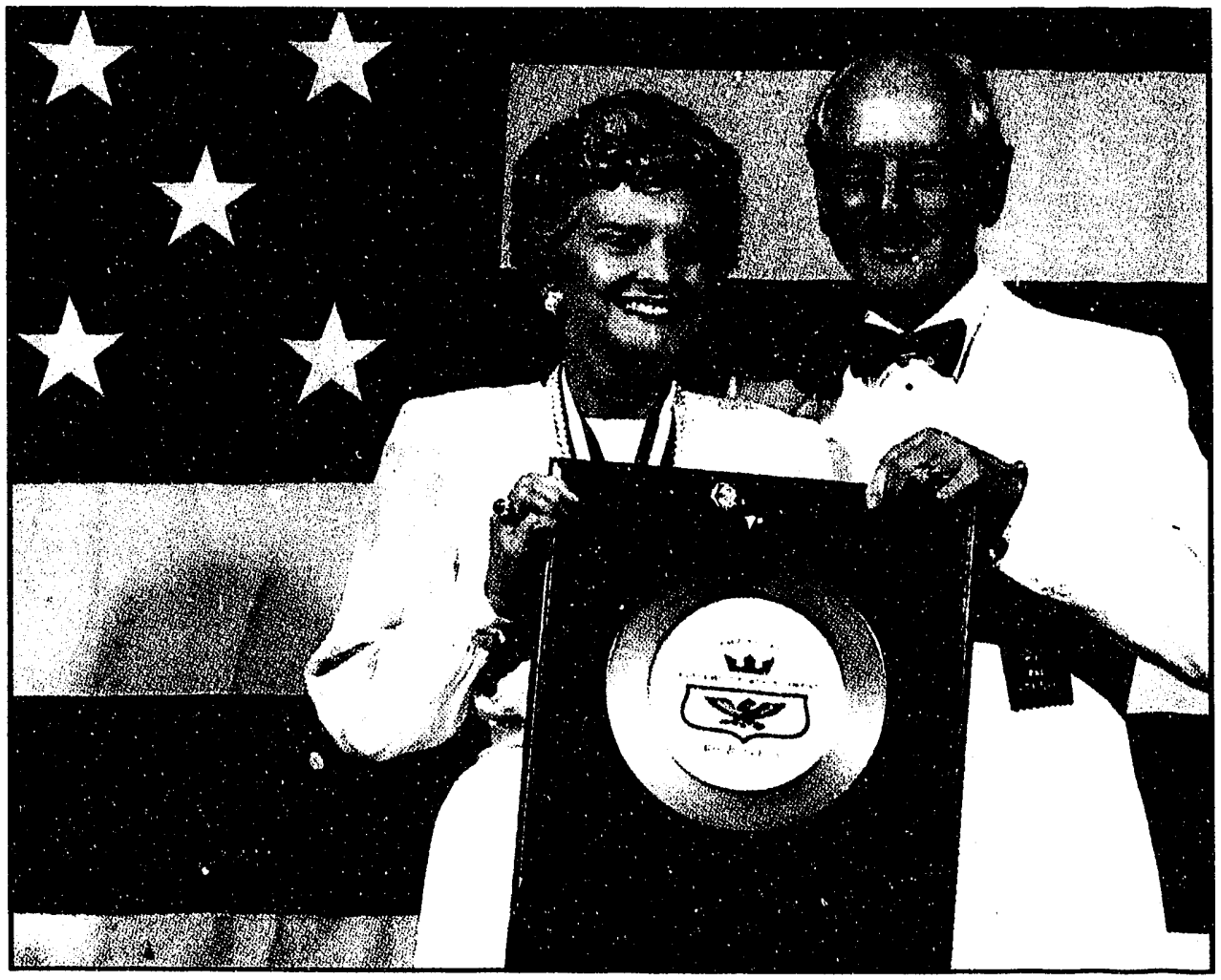

Figure 55. Former First Lady Betty Ford receiving the Golden Plate award from Ernest Hahn at the American Academy of Achievement's "Salute to Excel!: nce," Denver, CO, June 29, 1985 . 
I feel that I have had an especially good rapport with Gerald Ford and am pleased that he has consented to serve as co-chairman of the banquet in horor of my 80th birthday to be held in the Palace Hotel in San Francisco on November 9, 1992.

\section{Iames Earl (ذimmy) Carter, Ir.}

My first contacts with Jimmy Carter were indirect, through such mutual friends as Admiral Hyman Rickover, related to Carter's early career in the nurlear Navy and my involvement in the development of nuclear energy. Later, when Carter became president, I often kept in touch with him thro.jgh our mutual friend Sol Linowitz to pass on suggestions regarding the development of nuclear power, steps to be taken in arms limitation including the promotion of a comprehensive nuclear test ban, and so forth. Although President Carter's early stint as a nuclear engineer should have given us a common bond (and I believe it did), he was not an advocate for civilian nuclear power during his presidency.

On June 5,1979, scientists and others were called to the White House for a briefing on the pending SALT II Treaty and a discussion of its implications:

"I walked to the White House, entered the southwest gate, then the South portal of the White House, went up one floor to a reception room where I joined those waiting to attend the breakfast at which President Jimmy Carter and others were scheduled to brief us on SALT II. Present in the group to be br iefed were: Bob McNamara (President of the World Bank), James Van Allen (Iowa State University), Paul Doty (Harvard), Isidor Rabi (Emeritus Professor, Physics Department, Columbia University), Frank Borman (Chairman of the Board of American Airlines), Alvin Weinberg, Frank Long (Cornell), Carl Sagan, Phil Abelson (Editor, Science magazine), Lee DuBridge, Lewis Branscomb (IBM), E. L. (Ed) Goldwasser, Norman Hackerman (Rice University and Chairman of the Natinnal Science Board), Lyman Fink, Herman Postma (Director of ORNL), an a ten or fifteen others, along with Frank Press (Science Adviser to the President), Ann Keatley (Assistant to Frank Press), Spurgeon Keeny (Deputy Director of ACDA), Ann Wexler (Assistant to the President).

At a little after 8 a.m. we went into the Family Dining Room where four tables were set up for breakfast with a speaker's podium set up at the far end. I sat at a table with Bob McNamara, James Van Allen, Paul Doty, Isidor Rabi and others. During breakfast I had a good chance to talk with Bob McNamara. He mentioned that he still gets a thrill every time he is in the White House and I told him that I feel the same. We reminisced about our work together in the Kennedy and Johnson administrations. He recalled with especial pleasure his visit to Berkeley in the spring of 1962 when President John F. Kennedy gave his exciting 
speech at the Charter Day exercises in a completely full Memorial Stadium. It was at this time that I also attended the dinner of the Alumni Association to accept, on his behalf, McNamara's Alumnus Of The Year Award. We discussed John Kennedy's excellent leadership in successfully obtaining the Limited Test Ban Treaty and I told him that I am using my notes to do some writing to describe this period and this accomplishment; he said that he thinks this is a good idea, that he hopes that I have kept some notes which apparently he has not.

I asked Bob what he is doing these days and ho indicated that he thinks that in his role as President of the World Bank, he has made a break-through in aiding the poor people in developing countries; the route he has developed is to work to aid the poorest segment directly rather than using the old theory that aid to the government of the country as a whole would filter down to the poor and hence benefit them because the country as a whole has increased its productivity.

We discussed the energy problem and he vehemently agreed with me that our country is making a terrible mistake to continue to rely on the tremendous outflow of II.S. dollars in order to buy oil. He, too, thinks that there should be more emphasis on the development of energy supply and that we should have started at least five years ago with a program of liquefying coal. I told him that I believe that we should have in the past or at least should now, develop an "energy budget" and then proceed to try to produce the energy needed to meet that budget. I asked him if he would nationalize the oil industry and he said definitely not, that he would use the market place to encourage production although he conceded that it probably would be necessary for the government to guarantee the price of oil produced by the liquefaction of coal, etc.

After we finished breakfast at about 8:40 a.m. or so, Frank Press went to the podium and told us that the reason for the meeting is to give the high level members of the scientific community (establishment) present in the room a briefing on SALT II which would be done by President Carter, who would enter the room about 8:45 a.m., followed by Defense Secretary Harold Brown and Deputy Defense Secretary for Research and Engineering William Perry. He emphasized the importance of the scientific community in supporting SALT II and the need for members of the scientific community to testify before Congress in support of SALT II. Such testimony was important for the ratification by the Senate of SALTI. He also mentioned the role of scientists historically beginning with the famous Albert Einstein letter that initiated the atomic bomb project, their role in raising the DNA issue, etc.

President Carter entered the room at about 8:45 a.m. or a few minutes thereafter. He went immedintely to the podium. He thanked us for coming, said this is one of a series of meetings with key people for briefings on SALT II. He went on to say that SALT II enhances our security, contributes to world peace, and contributes to the whole process of arms limitations started by President Eisenhower. He said the SALT Treaty is and well balanced, will increase the confidence of our allies 
in our intentions, will increase the stability of our relations with the Soviets, will help prevent the proliferation of nuclear weapons. He said that many nations are now in a position where they could produce nuclear weapons within a period of a few months and mentioned for example, Brazil, Argentina, Israel, Pakistan, South Africa, South Korea and others. The President said that if SALT II is rejected by the Senate, it would be ridiculous to ask these nations to desist from building nuclear weapons. He said the Treaty is verifiable and is not based on trust of the Soviets, and without SALT II our abilities for verification would be greatly curtailed.

He then described some of the provisions of SALT II, such as the limitations it places on the number of reentry vehicles, on new types of reentry vehicles, etc. Without SALT II we would be in great doubt as to the Soviet capability. Without the restraints imposed by SALT II, the Soviet's momentum in building up still more weapons of destruction would have to be met by us in an escalating race.

The President said that we have been tough negotiators in arriving at the final text of SALT II, but so have the Soviets. The negotiations have proceeded during seven uninterrupted years and have involved the President himself, some thirty members of Congress, and throughout the process the. American public has been kept continuously informed. The Treaty, in its specificity far exceeds that of any previous treaties. For example, its constraints require the Soviets to dismantle about $10 \%$ of its missiles.

The President went on to say that from the standpoint of his Presidency, his involvement with SALT II and the decisions that he has made in this connection are the most important. He emphasized that the issue is still in doubt; he said he could not face the world as the President of the U.S. if SALT II is rejected. Under these circumstances the countries of the world would have to look eastward, the effectiveness of NATO would be jeopardized, the Soviets could then project themselves as a strong peace-loving nation in contrast to the non-peace-loving nature of the U.S.

The President then brought the discussion to an end and asked for questions. Paul Doty asked why there wasn't a common option on heavy missiles on both sides and the President indicated that this is coming--the Soviets have agreed to limitation to a total of 10 SSAT's and we would then have 10 MX's. Isidor Rabi asked whether SALT II isn't part of a general momentum toward further progress, that is, towards more significant steps to follow and the President replied tha. the Soviets look to $S A L T$ as a continuance of peaceful coexistence or détente, .. Id that SALT II should be followed by SALT III, the comprehensive test ban and antisatellite agreements. Frank Long asked whether we could be optimistic about a comprehensive test ban and the President answered "Yes," that we have made progress, "at the Soviets have finally agreed to drop peaceful uses of nuclear explosives and are now ready to accept detection devices on their own soil. However, if there are 10 devices in the Soviet Union (the number now under discussion) they want 10 devices in the United States and 10 devices in the United Kingdom. The present discussions are 
suggesting a three-year ban on all nuclear tests to be followed by some proof testing of existing nuclear weapons.

Lee DuBridge asked what kind of amendments can be made in order to satisfy members of Congress so that they will change their opposition to a vote for the Treaty and the President replied, "practically none." He said that the Soviets would reject any amendment that would be to their detriment and obviously the U.S. would not suggest amendments that would be to its detriment.

Carl Sagan said that there has been much criticism that SALT II has the form but not the content of a serious treaty and asked, therefore, if the President was satisfied and he replied, "No," because actually there will be, even with SALT II, an increase in missiles on both sides. However, this is the first time that a limit has been put on existing missiles, on the MIRVing of missiles, etc. SALT III will be discussed between him and Brezhnev at their Vienna meeting and this will have as its primary goal a reduction of numerical numbers and better verifiability.

Fink recognized the difficulty of going to a total elimination of nuclear weapons and the President replied, "This is my goal." He has discussed this with Deng Xiaoping (Vice Premier of the People's Republic of China), James Callaghan (Prime Minister of the United Kingdom) and Valery Giscard d'Estaing (President of France) and they all agree that this is an ultimate goal.

Another question concerned the importance of the European Theatre and the President replied that SALT III will provide for consultation with our allies on Theatre nuclear weapons.

The President concluded by saying that we have had remarkeble uniformity of support for SALT II throughout the government although some Chiefs of Staff would prefer some different aspects in the Treaty--this seemed to imply that they might not support it in its present form.

The President left the meeting at about 9:30 a.m.

Harold Brown then went to the podium; he described the content of SALT II, stated that SALT II will not solve all our strategic problems, that beyond the military aspects there are broader aspects such as nonproliferation, relations with our allies, etc. He said our relationship with the USSR will remain competitive even with SALT II, but SALT II will help ameliorate the competitiveness. He concluded by picturing the horrible effects of nuclear explosions, with which a number of those present are familiar, and said it is the prevention of this that is at stake.

Lee DuBridge asked Harold Brown if there is a difference of opinion in the military concerning the suppori of SALT II. Brown answered this obliquely by saying that some military people know what they can do in a military way but are uncomfortable witn what SALT II can do. He said this is not the attitude of the Joint Chiefs of Staff but then 
went on to say that not all the Joint Chiefs of Staff will necessarily support SALT II. Weinberg raised the question of whether the U.S. shouldn't have a Civil Defense program and Brown replied that this is not a very effective tack; it was tried in the early 1960's when it was demonstrated that it doesn't come easily in the U.S. After another question or two, Brown brought his part to an end and called on Bill Perry to come forward for his presentation.

I left the meeting at this time, that is at about 9:50 a.m."

I recall another occasion on October 20,1979. I went to Boston for the dedication of the John Fitzgerald Kennedy Library where I saw President Carter play a central role in the dedication ceremonies:

"I had breakfast in the Howard Johnson 57 Park Plaza Hotel with Sol and Toni Linowitz (u!? I happened to meet as we were standing in line). Sol told me that he has again talked to President Carter about my having one of the four part-time positions on the Energy Mobilization Board. I talked to Pat and Bernice Brown; he said he is stomping the country for Jerry.

After breakfast, we took one of the buses to the site of the Kennedy Library at Columbus Point on Dorchester Bay. Since Sol and Toni had tickets for the reserved area, I followed along with them and we managed to find seats in the second row on the right hand side, just in front of the speaker's rostrum.

At a little after 10:30 a.m. those to be seated on the platform entered and a little after that President Jimmy Carter and Rosalynn Carter entered. The President kissed Joan Kennedy (who reacted cordially) and Jacqueline Kennedy Onassis (who jumped back to try to avoid the kiss by Carter) as he passed down the line of those seated in the front row. In the front row from right to left (from the standpoint of those seated in the audience) were:

1. the woman who served as translator of the proceedings using sign language for the deaf

2. Sargent Shriver

3. Mrs. Sargent Shriver (Eunice Kennedy)

4. Patricia Kennedy Lawford

5. Mrs. Steve Smith (Jean Kennedy)

6. Steve Smith

7. Mrs. Robert (Ethel) Kennedy

8. Joseph P. Kennedy, II

9. Sally Willamen (the winner of an essay contest concerning the John F. Kennedy Library and its function)

10. Reverend Herbert Meza, Church of the Pilgrim, Washington, D.C. 
11. Archbishop Humberto Cardinal Medeiros, Archbishop of Boston

12. Rosalynn Carter

13. President Carter

14. Joan [Mrs. Edward] Kennedy

15. Edward (Teddy) Kennedy

16. Lady Bird Johnson

17. unidentified man

18. Jacqueline Onassis

19. John F. Kennedy, Jr.

20. Caroline Kennedy

The dedication proceeded according to the program. During the opening musical selection by the Boston Pops Esplanade Orchestra conducted by Harry Ellis Dickson, Jimmy Carter and Joan Kennedy talked animatedly and the President held Joan's hand part of the time.

Stephen E. Smith, President of the John Fitzgerald Kennedy Library Corporation, opened the speaker's program with some introductory remarks. He acknowledged the help of those who had worked to mole the Kennedy Library possible; he gave special mention to Mrs. Patricia Lawford.

Caroline Kennedy then made a short welcoming statement speaking extemporaneously; she did very well. She then introduced her brother, John F. Kennedy, Jr., who read a poem by Steven Spender. When he returned to his place next to Caroline, she gave him a kiss expressing approbation for his creditable performance. The Invocation was then given by Archbishop of Boston, Humberto Cardinal Medeiros, followed by the playing and singing of the National Anthem.

Joseph P. Kennedy, II, (the eldest son of Robert and Ethel Kennedy) then gave his talk, "The Unfinished Business of Robert F. Kennedy." He talked in rather strident tones emphasizing the need for more attention for the poor. He criticized the recent action of the Chairman of the Federal Reserve Bank, looking at President Carter as he did so, which was directed toward creating a recession in order to fight inflation.

Next, John F. Kennedy, Jr. and President Carter came to the podium and John, Jr., without making any remarks, handed the keys of the Library Building to Presinent Carter, symbolic of the gift of the Library Building to the U.S. Government.

This action served as the introduction for President Carter's remarks. President Carter used the late President's own words to jokingly advise JFK's brother, Senator Edward Kennedy, not to seek the presidency. He recalled that President Kennedy was reminded at a March, 1962, press conference that younger brother Ted had observed the ravages of the 
presidency showing on his elder brother and commented that he might never want to be president. "Would you run again for the presidency?," a reporter asked him at that conference, "and would you recommend it to anyone else?" Carter recalled the response: "I do not recommend it to others--at least for a while." Then, he added: "President Kennedy's wit, and also his wisdom, is certainly as relevant today as it was then." In President Carter's references to legislation passed after the death of Kennedy, he failed to mention Lyndon B. Johnson's name.

President Carter's address was followed by an address by Edward M. Kennedy which he began without making a salutation to President Carter, but he did turn toward him and make references to him in his talk which was mainly on the accomplishments of his brother. He made reference to the fact that his brother had taught him to ride a bicycle, toss a football, and sail against the wind. He made reference to the fact that his brother, John, was the person he looked to for help when he was a boy; he said that his brother, John, returned to Boston as his home when he needed spiritual help.

Stephen Smith, as Master of Ceremonies, introduced Jacqueline Kennedy Onassis, Lady Bird Johnson, and Ethel Kennedy, who each stood up.

At this point recordings were played of excerpts from a number of John F. Kennedy's speeches, a very moving experience. The great similarity between the voices of John and Edward were apparent to those present.

The program was brought to an end by the Benediction by The Reverend Herbert Meza, Church of the Pilgrim, Washington, D.C., and the singing of "America The Beautiful" by the audience. Those on the stage and the members of the various "families Kennedy" who were sitting in the first two rows center, then filed out and went to visit the Library (President Carter and Rosalynn Carter had visited the Library earlier and soon left)....

In the course of my attendance at the ceremcny and afterwards I met and talked to (or greeted) the following people:

- The Robert McNamaras

- The McGeorge Bundys

- The Willard Wirtzs

- The Taz Shepards

- The Averell Harrimans (in response to my question, he told me he had not written an article on the Test Ban Treaty and the best source of information is Butch Fisher who accompanied him to Moscow for the final negotiations.)

- John Macy

- Antony Celebreze

- The Stewart Udalls 
- Orville and Jane Freeman

- Douglas Dillon

- The Newton Minows

- James and Estelle Ramey

- Joseph Swu'ler

- The Jim Faheys (he is the author of Pacific War Diary and will send me a copy; our picture was taken together)

- James Carr (he asked for a copy of my statistics used in my "Energy" talk)

- Walter and Elspeth Rostow (she is the Dean of the Lyndon B. Johnson School of Public Affairs at the University of Texas at Austin)

- George McGhee

- Dean Rusk (in distance)

- Ed Day (in distarice)

- Jody Powell (in distance)

- Stu Eizenstadt (in distance)

- Peter Duchin

- The Kennedy children nearby"

I also have häd rinany encounters with Carter's vice president, Walter F. Mondale, beginning in 1965 when he began his service as a U.S. Senator from Minnesota. Helen and I also became acquainted with his wife Joan. An interesting encounter occurred at the Hilton Hotel in San Francisco on Monday, August 30, 1976, during his successful campaign for the vice presidency of the United States as Jimmy Carter's running mate:

to the Imperial

"I went down

Ballroom to hear

Senator Walter

Mondal'e's talk to the

Commonwealth Club.

I sat at a

Commonwealth Club

Board of Governors table with Mr. and Mrs. Howard Vesper, Vernon Goodman, and others. Mondale opened his talk, "A Major Foreign Policy Address," with some clever ad libs, then followed his text with some cuts.

(Figure 56.) He handled the questionand-answer period

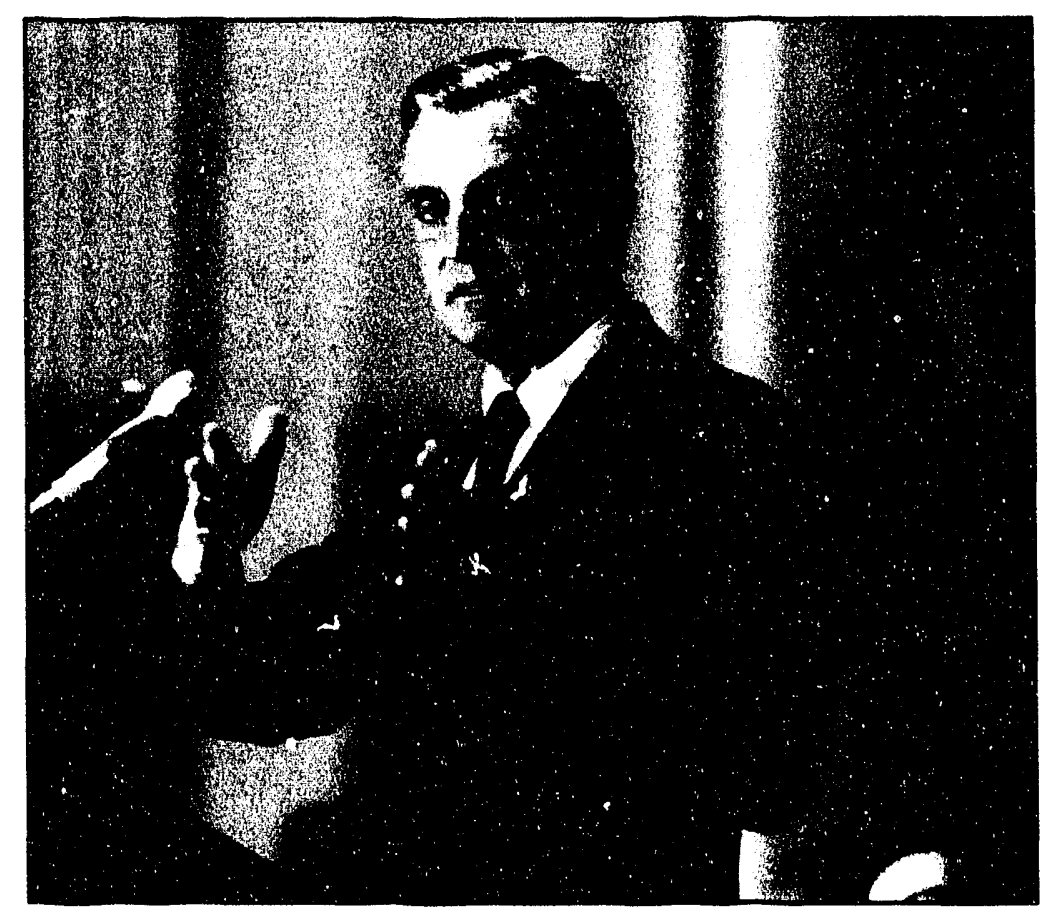

Figure 56. Minnesota Senator and vice-presidential candidate Walter F. Mondale speaking to the Commonwealth Club, Hilton Hotel, San Francisco, August 30, 1976. 
quite well. This and the talk included a good deal of scientific-technical material on energy sources and nuclear arms buildup and arms control.

After the talk I went up and talked to him, complimented him on his handling of the technical material (he expressed some apprehension about it), then told him about my request to see Carter to discuss, as a representative of the ACS, of which I am President this Centennial year, energy policy and science policy; he said he is seeing Carter next week, will bring my previous written request to his attention. Mondale asked me to brief his assistant, Jim Johnson, who was standing nearby, on this matter, which I did.

I was then interviewed by Linda Schacht of Channel 9 on Mondale's speech. I said he handled the 'echnical aspects quite well, I probably will vote for him depending on campaign postures, knew him quite well as a friend during my tenure in Washington."

I had another encounter with Jimmy Carter at the Salute to Excellence Dinner of the American Academy of Achievement in Minneapolis, Minnesota on July 7, 1984, which Helen also attended:

"At the reception Helen and I talked to many interesting people. Jimmy Carter approached us and said I am one of his heroes, and he has been a great admirer of me for years. I mentioned my interest in a comprehensive test ban and he asked Ted Turner to join us and we described to Ted the values of a CTB. Jimmy said he failed to git a CTB in part because the British insisted on their quota of on-site inspections. I gave Ted a copy of my Chemical and Engineering News editorial on the CTB. An Academy photographer took pictures of me with Carter and Turner. (Figure 57.) Helen and I also met and talked with Rosalynn Carter." (Figure 58.)

I am pleased that Jimmy Carter is also serving as co-chairman for the dinner honoring my 80th birthday at the Palace Hotel in San Francisco on November 9,1992 . In view of his background as a nuclear engineer, I have felt especially close to him. 
Figure 57.

(right)

Ted Turner (with back to camera), President Jimmy Carter, and Seaborg at the American Academy of Achievement's

"Salute to

Excellence" dinner,

Minneapolis, MN, July 7, 1984.

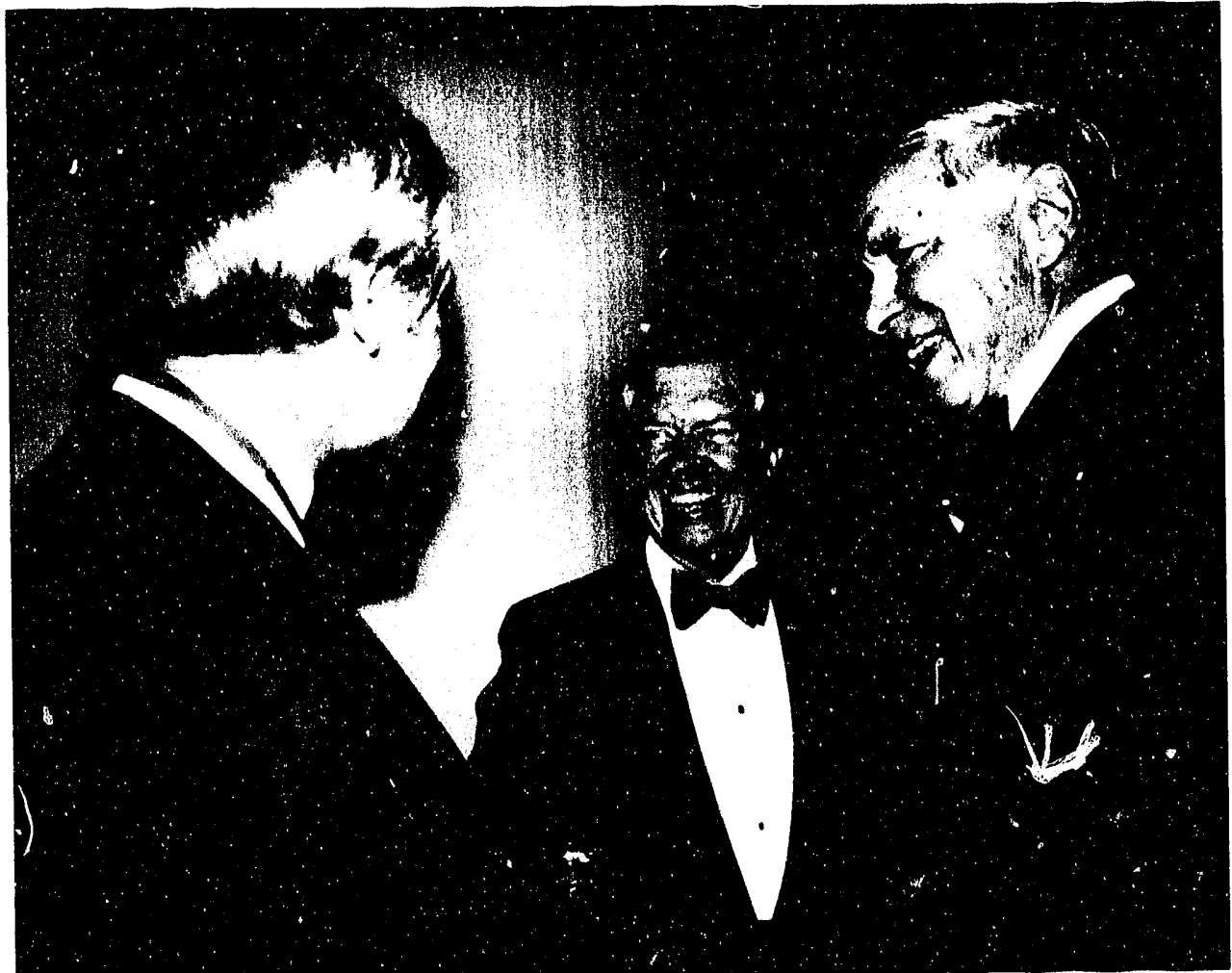

Figure 58.

(left)

Former First Lady Rosalynn Carter at the American Academy of Achievement's "Salute to Excellence," Minneapolis, MN, July 7 , 1984. (President Jimmy Carter seated.) 


\section{Ronald Wilson Reagan}

I first encountered Ronald Reagan when he was Governor of California, during which time I met him on a number of occasions, including the breakfast at the Bohemian Grove on July 23, 1967, as described above in Section 6.

Soon after Reagan became president, in the summer of 1981, I was appointed by Secretary of Education Ted Bell to the National Commission on Excellence in Education (NCEE), which then University of Utah President David P. Gardner served as chairman. Working over a period of about 18 months, we produced the famous report, "A Nation At Risk," which we presented to President Reagan in a White House ceremony on Tuesday, April 26, 1983:

"I took a taxi to the Ramada Renaissance Hotel (1143 New Hampshire Avenue), where in the New Hampshire 2 Room, I joined the luncheon meeting of NCEE members and staff. Present were David Gardner (Chairman), Yvonne Larsen, William O. Baker, Anne Campbell, Emeral A. Crosby, Charles Foster, Jr., Norman Francis, Shirley Gordon, Robert V. Haderlein, Gerald Holton, Annette Kirk, Margaret Marston, Albert H. Quie, Jay Sommer, Richard Wallace, I, and essentially all of the staff. We were given copies of our NCEE report, entitled "A Nation at Risk: The Imperative for Educational Reform." (There is no indication of an Open Letter to the American People on the cover, only a small lettered mention in the inside title page.) There are 36 pages in the main (essay) section which includes th ecommendations. We were also given a flyer with the same title describing the report and including a report Order Form (cost \$4.50).

At the luncheon table, after we finished eating, Gardner and Ted Bell made some remarks uj appreciation, etc., and Bell presented each Commission member with a certificate of appreciation, individually and with photographs taken. After the luncheon we went out into the foyer and asked our fellow Commissioners to autcgraph our copies of the report. We re-assembled in the New Hampshire 2 Room at 2 p.m. to hold our final meeting. Ne formally adopted the report by a unanimous vote and then discussed methods of distributing it. (Each Commissioner was given five copies and will be sent 100 additional copies.) Copies will be sent to every member of Congress, all state Governors, state legislatures, the head of AFL-CIO, National Education Association (Mary Futrell, SecretaryTreasurer), the American Federation of Teachers (Albert Shanker, President), the American Association of School Administrators (Paul Salman, Executive Director), the National Association of Secondary School Principals (Scott Thompson, Executive Director), the United States Chamber of Commerce, the Business Roundtable, and many other organizations. Goldberg will send Commission members a list of organizations that received the report and a batch of newspaper clippings of coverage of the report.

At the conclusion of the meeting, which ended at about 3 p.m., I called Pat Rupp at my LBL office, took care of a few business items, and 
then rode to the White House with the Commission members in a van. Staff and friends went in automobiles. First we went to the Red Room before entering the State Dining Room where the ceremony was to be held before an audience of some 200-300 invited people and numerous representatives of the press (newspapers, radio, TV, etc.).

Beginning at about 3:45 p.m., there were speeches by Gardner (who, along with Yvonne Larsen and Ted Bell sat on the stage back of the lectern) and then Bell, who spoke until President Reagan arrived. I sat next to Gary Jones (Under Secretary of Education). President Reagan spoke from a prepared text and in large measure embraced and endorsed our report. However, and unfortunately in my opinion, he interpreted our report as a "call for an end to Federal intrusion" saying that it "is consistent with our task of redefining the Federal role in education" and he added "we'll contirue to work in the months ahead for passage of tuition tax credits, vouchers, educational savings accounts, voluntary school prayer and abolishing the Department of Education." He included the charming comment that when Eureka College recently awarded him an honorary degree, he didn't really deserve it because when he graduated he considered the degree they awarded him then as an honorary one. Also when he misspoke saying "compromise" instead of "comprise!," he said it must be a Freudian slip because he has so much on his mind his attempts to arrive at compromises with Congress.

Upon completion of his talk, which must have taken somewhere between five and ten minutes, he stepped down and went to the front row to shake hands with some members of Congress and with some members of the National Commission on Excellence in Education, including me.

Photographers took pictures (including a picture of me shaking hands with President Reagan, which appeared in the New York Times the following day, Wednesday, April 27)." (Figure 59.)

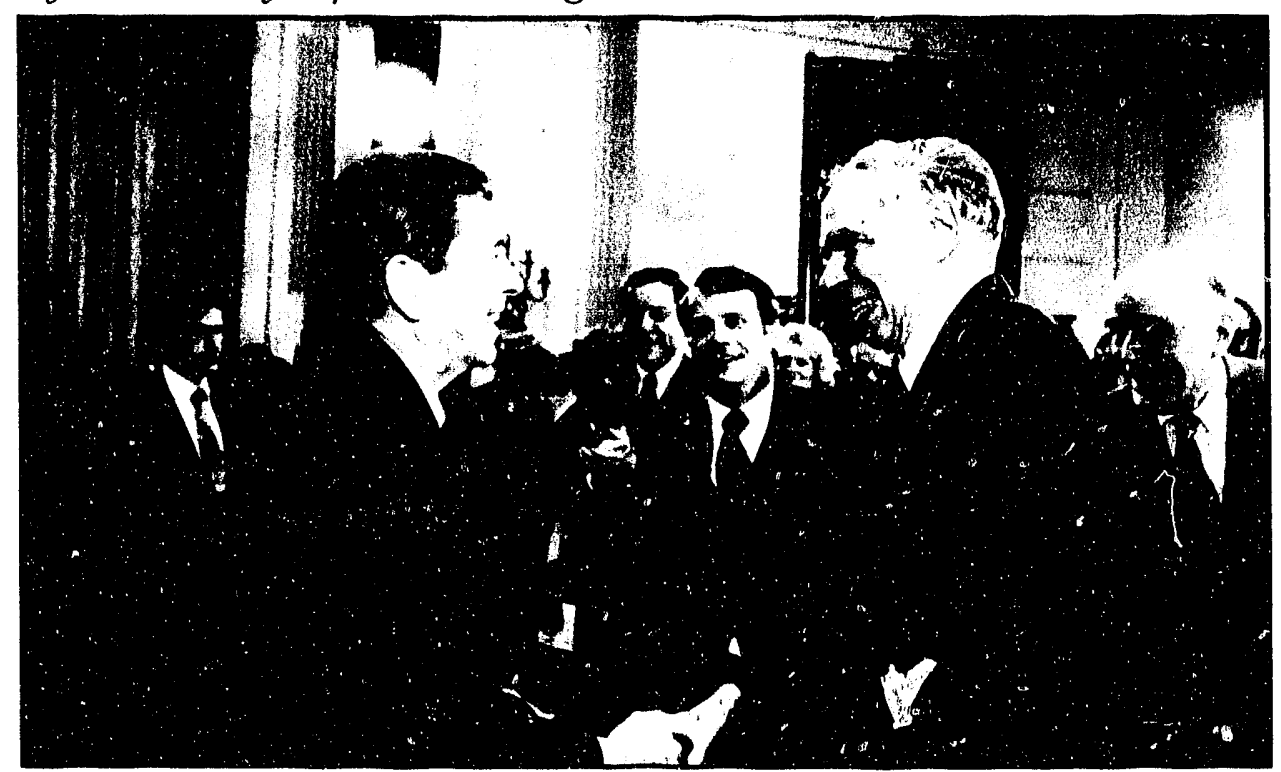

Figure 59. President Ronald W. Reagan talking with Seaborg on the occassion of the presentation of the National Commission on Excellence in Education (NCEE) report "A Nation At Risk," State Dining Room, White House, April 26, 1983. 
After the ceremony I was approached by reporters who asked me to identify the places in our report "A Nation at Risk" where we advocatedsuch concepts as "vouchers" and "prayer in schools." I replied (I believe diplomatically) that our report made no references to any such recommendations. This part of the president's remarks was, fortunately, ignored by the press.

After our issuance of our report "A Nation At Risk," the members of our National Commission on Excellence in Education, and even President Reagan, were involved in a number of meetings throughout the country designed to encourage the implementation of the recommendations of our Report. One such occasion, in which President Reagan participated, occurred in Whittier, California on June 30, 1983:

"I had breakfast in the coffee shop and afterward, the NCEE members, panel members, etc., rode in siveral cars to Pioneer High School in Whittier. Here we went to the principal's office and then the gymnasium, where about 1,500 people were assembled, all of whom had gone through a security check. The forum was opened by NCEE Chairman David Gardner, seated at a table in the center of the gym. He introduced Mrs. Eve Burnett (President of the Whittier Union High School District Board of Trustees), who weic nid the audience. Senator William Campbell (Senate Minority Leader, Caitj: rnia) spoke briefly on behalf of Governor Deukmejian.

Gardner then introduced today's panel members and the five members of the National Commission on Excellence in Education present: Charles Foster, Norman Francis, Margaret Marston, Richard Wallace, and me. Directly after the introductions, at 9:30 a.m., President Ronald Reagan entered with Education Secretary Terrel Bell. The president began to speak immediately. He praised Pioneer High School and said that everyone is proud of it. He praised our NCEE report and said the nation should respond as it did in the 1950's. He said that we federal officials should identify with the national interest in education, but that local leadership is important. He praised Governor George Deukmejian's education program. He emphasized that home and family are the foundation for support of education and called for educational renewal and reform. Education must be the highest priority in America today. Pioneer High School was selected to be honored for excellence in education among exemplary schools chosen by the government, and the first to be honored from among 144 high schools selected.

The president who was flanked by Bell and Gardner and seated at the central table, then rose and presented to Superintendent Norman Eisin and Principal Robert Eicholz a huge flag with the letters "Pioneer High School, Excellence in Education, 1982-83." Superintendent Eisin then responded. He said the basic criterion for participation in athletics will be attendance, rint academic accomplishment. Bell then introduced Jaime Escalante (muth teacher, Garfield High School, Los Angeles). He asked President Reagan to sign his teacher's certificate. He decried the "Mickey 
Mouse" classes, and told about the increased math requirements at his high school.

Bell then called on Principal Robert Eicholz, who spoke on the emphasis on basic skills (reading, writing, math, etc.) at Pioneer High School. However, he also emphasized the importance of athletics, fine arts, business, etc. He placed emphasis on attendance and said he was getting help from parents in this and other regards. Bell then introduced Ralph Figueroa (student, California High School, Whittier), who praised the job Principal Eicholz does at Pioneer High School. Bell said the 143 other winners will be announced at noon today.

Again the president spoke, and emphasized the importance of extracurricular activities and described his contact with his high school principal in Dixon (who emphasized he only cared what Reagan would think of him 15 years from now, and not now), described how some of his fellow students were turned on by science classes, praised the dedication of teachers and told about a basketball player who hadn't learned to read or write and went back to the fourth grade when he was injured and could no longer play basketball.

The president started to leave at 10:15 a.m., recognized me as he came by and stopped to shake hands with me and other NCEE members and others. I mentioned to him that my son Eric (President of the American Hiking Society) had been present when he signed the Amendment to the National Trails Act. He left the gym at about 10:20 a.m."

Members of the NCEE (after Chairman David Gardner had assumed the presidency of the University of California) again met with President Reagan, in the Cabinet Room of the White House, on May 5, 1984:

"After the breakfast I rode in a van with the other ten members of the NCEE to the northwest gate of the White House. We went through the gate as our identifications were checked and then after waiting in an ante-room, we went to the Cabinet Room and took our places around the table. I sat on the chair labeled "Secretary of Energy." President T.eagan entered the room at about 11 a.m. and took his regular seat with David Gardner sitting to his left and Ted Bell to his right. (Figure 60.) President keagan opened his remarks with the humiorous comment that our National Commission has been so successful that he should have had it working on the national budget deficit problem. He indicated that the impact of our report has been very widespread. He referred to the deterioration of education in the United States and expressed the wish that the universities and colleges would eliminate the "bone-head" courses which have become rampant. Secretary Bell presented President Reagan with a copy of the report, "The Nation Responds," a 220-page report summarizing the activities across the country directed towards implementation of the recommendations in our report, "A Nation at Risk." The president responded that this would give him reading material for the weekend. When the length of the report was called to his attention, 


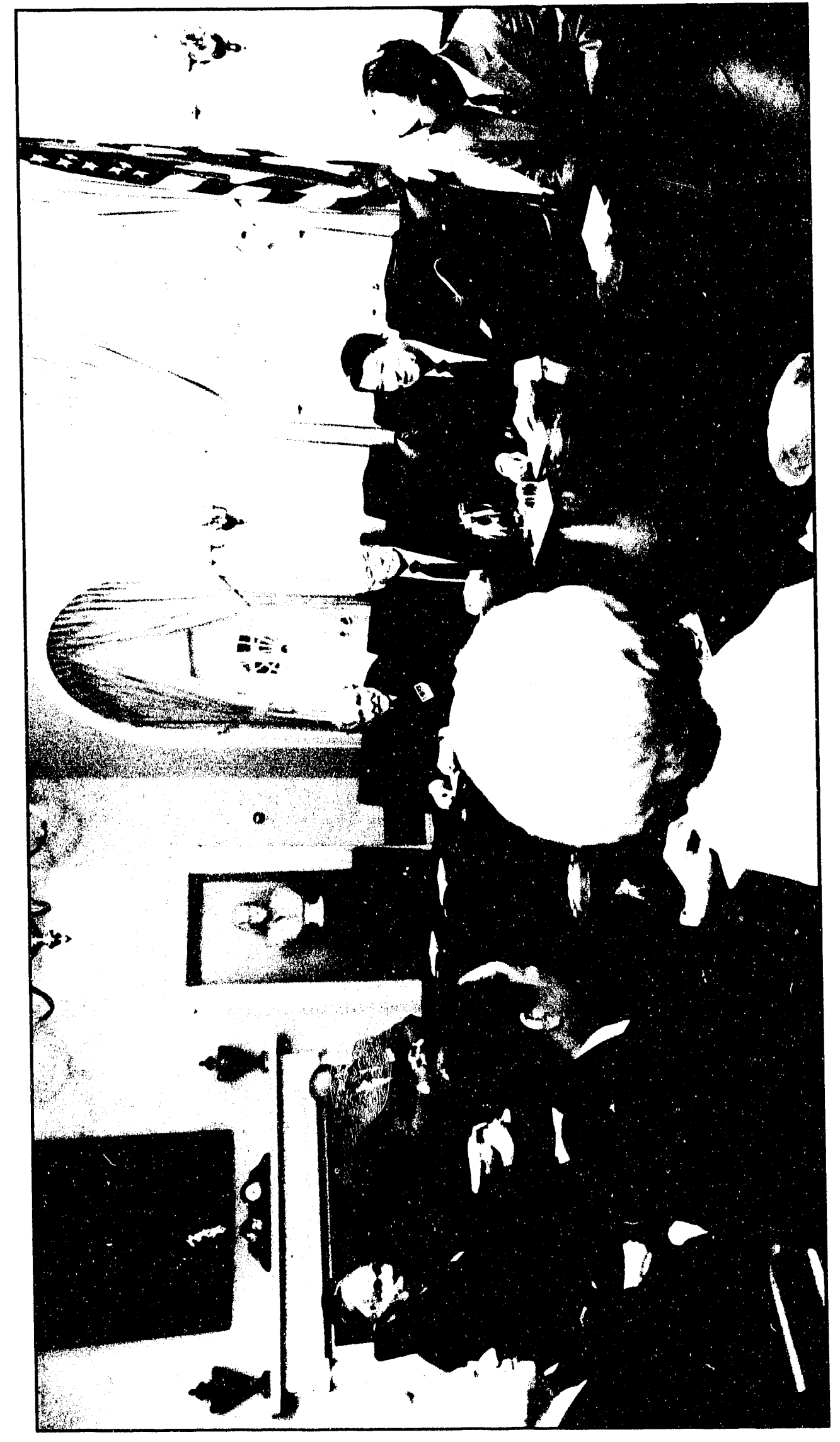

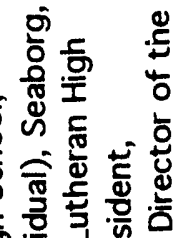

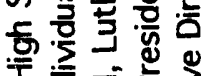

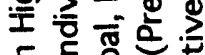
홍웡 웡 논 등 한 之 동

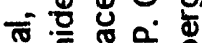

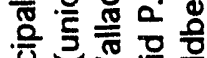
.

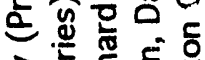

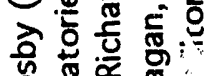
응

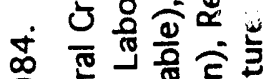

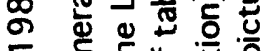
ज

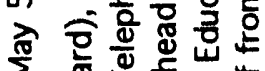
$\sum$ 要要范 i

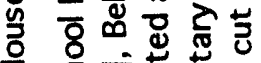
王

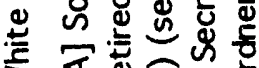

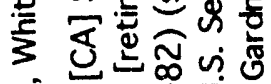

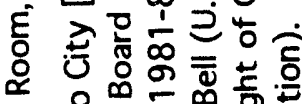
む

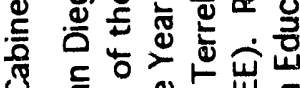
ర)

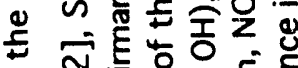
โ

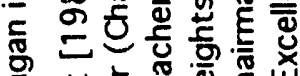

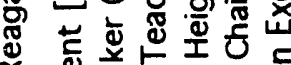
\& के 능

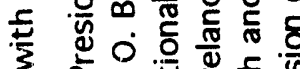
ड .

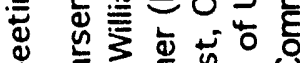
है

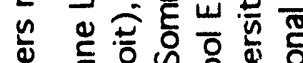

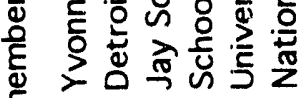

嵌

نं 站点

둥

矛定齿 
the president quipped that this additional paper has been made available because of the widespread cancellation and curtailment of government publications that have taken place under his administration.

Secretary Bell then called on David Gardner for his comments. David began by noting that the president was wearing Golden Bear cufflinks like he was and the president responded by acknowledging this and calling attention to his Golden Bear tie clip. Gardner said that the reason thut our report made a difference was because it made sense. He alluded to the fact that our report, "A Nation at Risk," made no mention of dollar amounts needed to reform education, saying the issue rather is whether we have made recommendations or not. It is in this manner that our society works. David emphasized that the report was not addressed to the government but to the American people. If they think that it makes sense, then things will happen for this is the way our country works best. He said that he had explained this to French President Mitterand when he talked to him at the luncheon we hosted for him in Berkeley. Gardner then added that our Cominission is grateful to President Reagan for moving the cause of education ahead. The reference to President Mitterand led President Reagan to make the remark that another Frenchman, de Tocqueville, made a similar comment when he visited the United States in 1830, that, "no bureaucracy was involved in moving our education forward."

President Rengan then told the story about the basketball star who, as a kid, was already six feet five inches tall in junior high school but who couldn't read or write by the time he reached the 11th grade in high school. However, he wanted a diploma but wasn't able to get the required courses which included such courses as "History of Baseball,", etc. He went back to school in Chicago in a fourth grade class and then plans to attend one of the campuses of the University of Illinois.

President Reagan then presented to David Gardner, a large glasscovered citation with copy of the front page of "A Nation at Risk," and with the inscription, "To David P. Gardner, in appreciation of your service to our Nation as a member of the National Commission on Excellence in Education," signed by Secretary Bell and Ronald Reagan. In so doing, the president stated that our Commission produced results in an almost magic manner. "We threw a bomb, created a miracle, parted the waters."

Following the presentation, the president presented to each of the ten members of the Nationui commission on Excellence in Education, individually, similarly large glass covered certificates. A photographer took a picture of each individual National Commission member with the president during the coirse of each presentation. (Figure 61.) I complimented Reagan on his meeting with John Lawrence and Alex Hollaender yesterday. 
We all

went to the south lawn for the presentation by the president of the Academic Fitness Awards. Besicies the 60 students, there were some 130 guests of the students, some 80 educators and a large contingent from the news media here to view the presentations. The presiden 1 emerged from the White House, strode to the lectern, looking unusually fit and in excellent physical condition, and then gave a rather outstanding talk on the

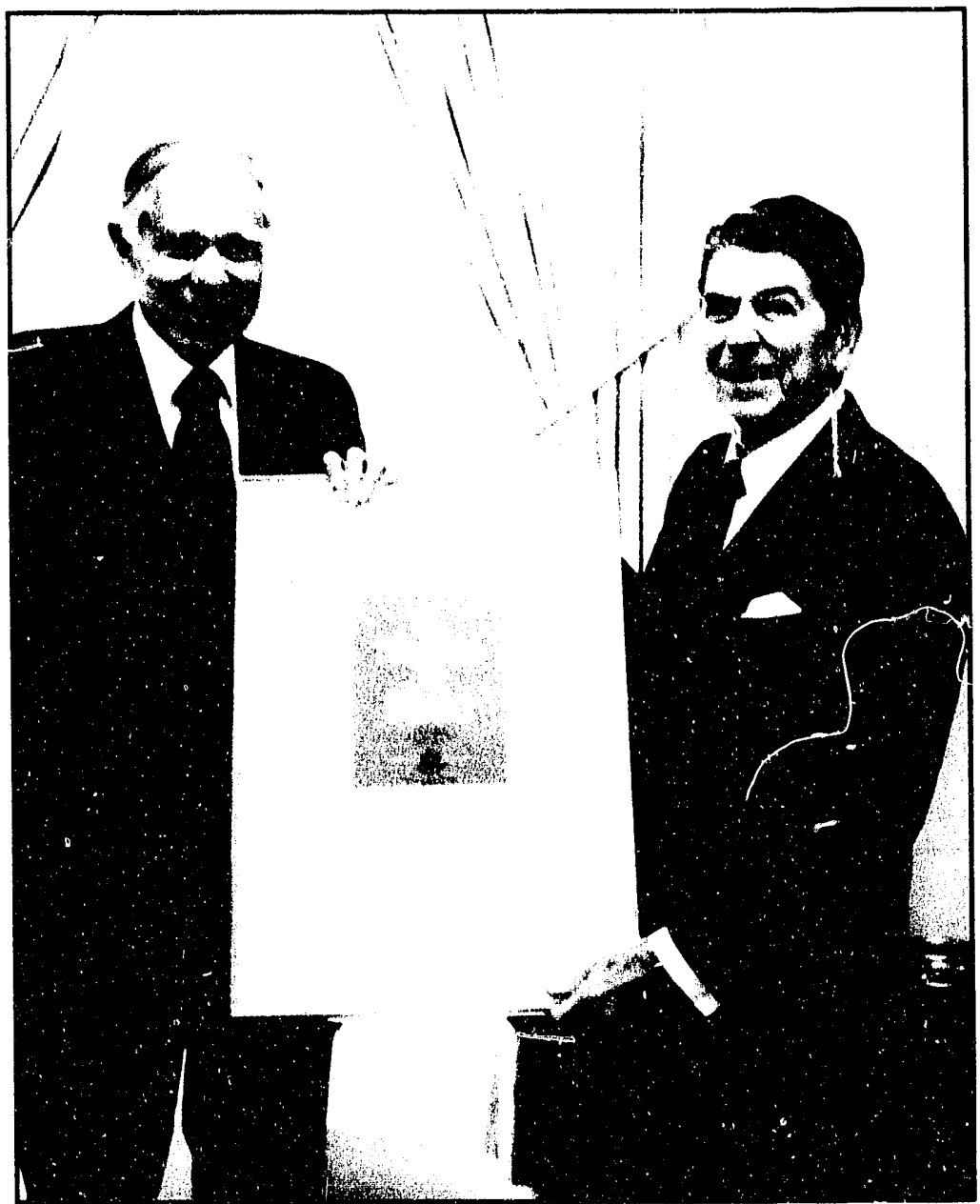

Figure 61. Seaborg receiving NCEE plaque from Reagan, Cabinet Room, White House, May 5, 1984.

educational

situation and

how the report of

our Commission has led to the needed reform in the United States. He quoted the sentence, "If an unfriendly foreign power had attempted to impose on America the mediocre educational performance that exists today, we might have viewed it as an act of war." (Last night during a conversation, Susan Tremaine said that NCEE staff refer to this sentence as the "Seaborg Sentence.")"

Helen and I attended a dinner in the White House in honor of Prime Minister Ingvar Carlsson of Sweden on September 9, 1987:

"After a while we changed into our formal clothes and took a taxi to the East Gate of the White House, where we arrived at about 7:20 p.m., to attend a dinner honoring the Prime Minister of Sweden, Ingvar Carlsson, and Mrs. Carlsson. We went through the metal detector apparatus and walked toward the west end of the White House. Our arrival was announced to the press corps, which consisted of a bevy of reporters and photographers. We went through, past this line, where our 
picture was taken by a number of the photographers. The reporter from the Washington Times, Lisa McCormack, asked me what I planned to take up with the president. I told her that I did not have any fixed agenda, that it was a social occasion. She asked what I would ask if I were going to take advantage of the opportunity and press some point with the president. I said I would urge him to support basic research in the United States so that we as a nation can compete in the high technology world. Reporters asked Helen whether this was our first visit to the White House, and she said it was for the Reagan Administration, but not with respect to earlier administrations.

As we emerged from the press line, we ran into Curtis and Arleen Carlson and exchanged greetings with them. We then went upstairs to the East Room (also known as the Gold Room), where again our entrance was announced. Here we talked to a number of the guests at the dinner. I first talked to Howard Baker. I recalled our pleasant and instructive relationship when he was a member of the Joint Committee on Atomic Energy and he agreed. He said he missed those days. I urged him to run for president, but he said he has had enough of the White. House during his six months there to cause him to not want to be president. He invitei me to have lunch with him the next time I come to Washington and said that he would include the Presidential Science Advisor, William Graham, if I would call him in order to make the appointment.

Helen and I had a rather long conversation with Supreme Court Chief Justice Bill Rehnquist and his wife Ann. We compared our origins, he in Wisconsin and I in Northern Michigan. He has a Swedish parent. Later Curtis Carlson and Helen talked to him about the possibility of his accepting a Great Swedish Heritage Award. They had only partial success because the indications are that he would not find time to travel very far to receive this honor. Among others we talked to during the reception were Ambassador Wilhelm Wachtmeister, Professor Burt Boland (Science Advisor to the Swedish Prime Minister), Professor Bengt Samuelsson of the Karolinska Institute, Daniel J. Boorstin (ex-Librarian of Congress) and his wife Ruth (I promised to send him a copy of Stemming the Tide and he promised in return to send me one of his books), Holly Coors (Special Representative to the 1987 National Year of the Americas), Utah Senator Orrin G. Hatch, M. Carl Holman (President, National Urban Coalition) and his wife Mary Ella, Florida Representative Bill McCollum, and James $H$. Webb, Jr. (Secretary of the Navy) and his wife Joanne.

We then went through the reception line (which included President Ronald and Nancy Reagan). As I passed President Ronald Reagan, I greeted him as a fellow Californian, (Figure 62.) and when I passed Prime Minister Ingvar Carlsson, he made a favorable comment about our corresponuince and said that we should discuss it later. As Helen passed President Reagan, she commented that he seemed to be in good shape, and he responded by leaning over to her and saying that you must not believe what you read in the newspapers. (Figure 63.) 


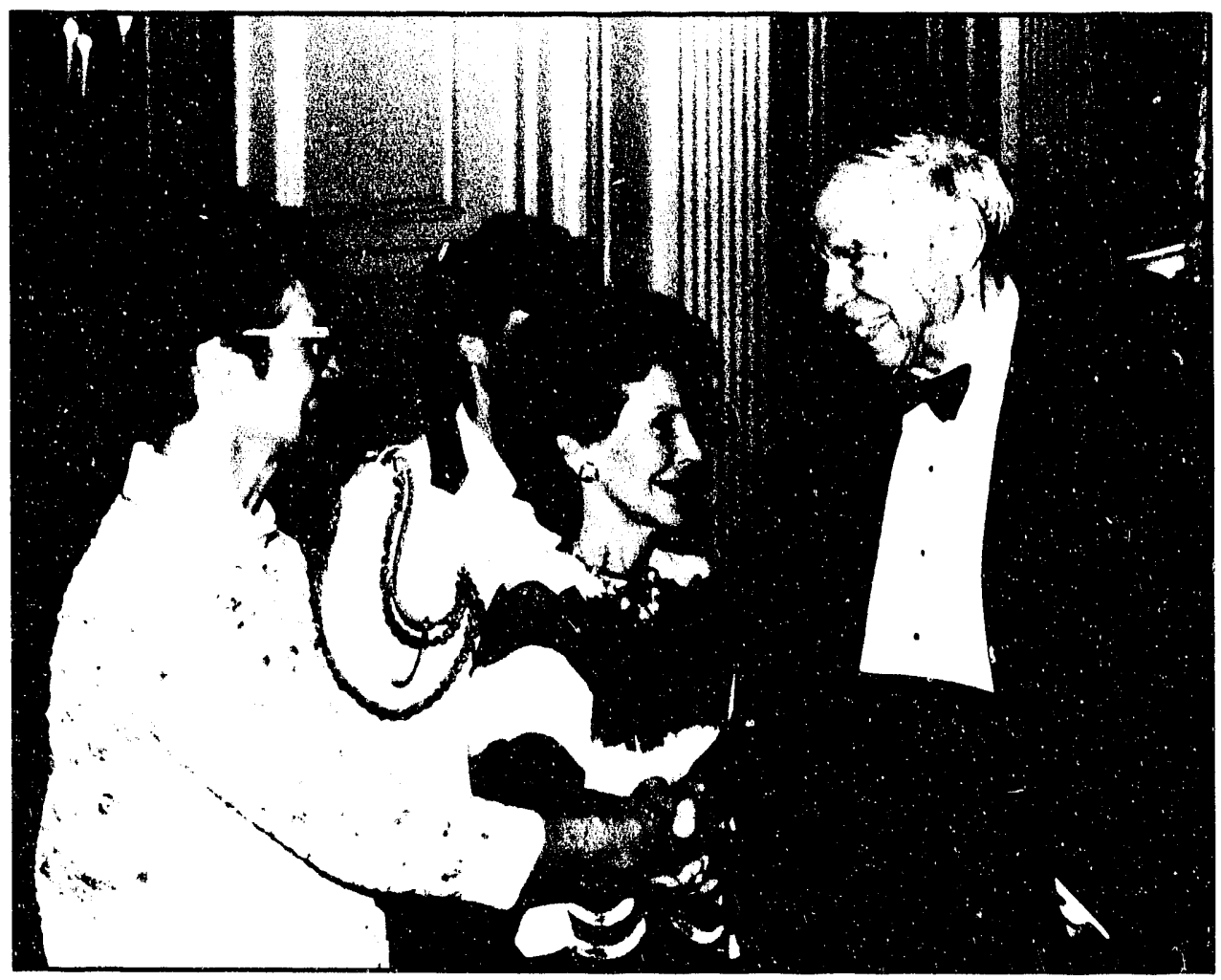

Figure 62.

(above)

Seaborg meeting Mrs. Ingrid Carisson [left] (wife of

Swedish Prime Minister) and

First Lad y Nancy Reagan

(center) at dinner in honor of Swedish Prime Minister Ingvar Carlsson, East Room, White House, September 9, 1987.

Helen Seaborg right of picture and just behind Seaborg.

Figure 63.

(right)

Reagan and Helen Seaborg at dinner in honor of Swedish Prime Minister Ingvar

Carlsson, East Room, White House, September 9, 1987.

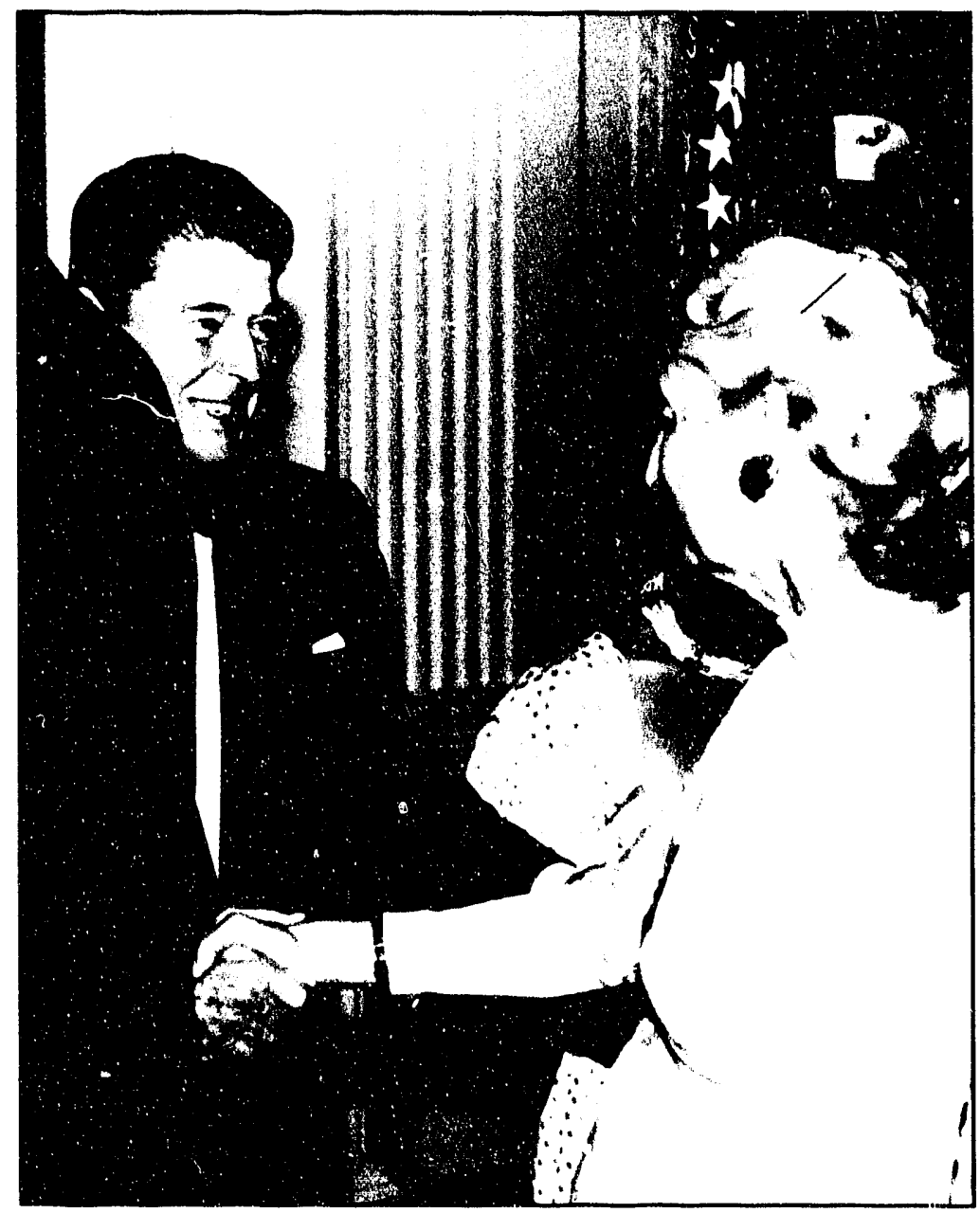


We proceeded to the State Dining Room where I talked to Björn Borg, the Swedish tennis star. He told me that Mats Wilander and Stefan Edberg had 'both won in the U.S. Open today and perhaps would be meeting in the semi-finals. He agreed that a good night's sleep and top mental attitude are essential for winning a close match.

In the State Dining Room I sat at a table with Mrs. Walker Percy (her husband is a famous author), Mrs. Seretean, Mrs. Rehnquist, Frank Neville Ikard, Ambassador Wachtmeister, Kenneth Walsh (White House correspondent, U.S. News and World Report), and Mary Evans (her husband is a former chairman of Union Pacific Corporation). I sat between Mrs. Percy and Mrs. Seretean. Helen sat at a table that included Chief Justice Bill Rehnquist (she sat next to him), Curtis Carlson, and Carl Holman (he sat next to her). My table was on one side of the table that included President Reagan, and Helen's table was on the other side, so we were quite close to him. Candice Bergen, as I learned later, was at the president's table.

After dinner we were serenaded by about a dozen people playing violin music. President Reagan then made some welcoming remarks, saying that our countries have been friends for as long as the United States has been a country. He also made note of the fact that the Carlssons will be celebrating their 30th wedding anniversary next week and will be visiting Northwestern University where Prime Minister Carlsson was a student in 1961.

Prime Minister Carlsson, who was at the table across the room from the president's table, responded with remarks that included reference to the historic breakthrough in the endeavor to start dismantling nuclear weapons that the U.S. is now engaged in. He also made reference to his nostalgic return visit to Northwestern University that he and his wife Ingrid are going to undertake.

After ci: ner I talked to Ulla Wachtmeister and to Pehr Gyllenhammar (Chairman and CEO of the Volvo company) and his wife Christina.

Since most of the people had gathered for coffee in the Blue Room (there were very few people in the neighboring Green Room and Red Room), Helen and I went in there. Here I had a long conversation with Prime Minister Carlsson. He told me that he has circulated our correspond:nce to his circle of advisors, and that they will come to a conclisiovi as to whether they will support the amendment approach to a test ban. Then, at a meeting of the leaders of the Six Nation Initiative to be held in Stockholm in January, this might be taken up. I told him that most of the other leaders of the Six Nation Initiative support the amendment approach, and he agreed. He said that in his meeting with President Reagan today he offered the services of the Six Nation Initiative to the verification of a comprehensive test ban, and President Reagan seemed to be more amenable than he had been to a comprehensive test ban. He recalled that he had met me when he was a boy on one of my visits with 
Swedish Prime Minister Tage Erlander. I told him that Sweden was a very important nation to show leadership in the test ban amendment approach, and he agreed.

Helen and I then went back to the East Room for the entertainment, which consisted of six songs and an encore by the singer Marilyn Horne. After dancing a while in the foyer entrance area, Helen and I walked back to the University Club. Helen and I retired a little before midnight."

I found President Reagan very personable and articulate. He was quick in repartee, which was not always clearly relevant. I am pleased that Ronald Reagan is serving as co-chairman as well for the dinner honoring my 80th birthday at the Palace Hotel in San Francisco on November 9, 1992.

\section{George Herbert Walker Bush}

I first got to know George Bush during the INixon Administration, when he was serving as the U.S. Ambassador to the United Nations. I recall on the morning of March 1, 1982, I walked from the Mayflower Hotel to the Executive Office Building with the 40 Science Talent Search finalists. We went to the Treaty Room (474) where Vice President George Bush greeted us. He made a fine talk about the importance of science and young people participating in it. He spotted me and greeted me during his talk. After his talk pictures were taken. I stood next to Vice President Bush in one of them (Figure 64.) and mentioned my acquaintance with Joanne Hall, who was his sister's roommate in colloge.

Helen and I met Vice President Bush and his wife Barbara at a reception hosted by Swedish Prime Minister Ingvar and Ingrid Carlsson at the Swedish Embassy on September 10, 1987:

"We went by the reception line--Swedish Ambassador Wilhelm and Ulla Wachtmeister, Swedish Prime Minister Ingvar and Ingrid Carlsson, and U.S. Vice President George and Barbara Bush.

(Figure 65.) Carlsson told me he had successful meetings today with the House and Senate Foreign Relations Committees. He discussed the comprehensive test ban with them and found a friendly reception....

After the supper there was a welcoming talk by Ambassador Wachtmeister (he told us that George Bush and Björn Borg had defeated him and Vitas Gerulitais at tennis this morning). Prime Minister Carlsson spoke next (he said he has had a very productive visit to the U.S.A., and he and Ingrid look forward to visiting Northwestern University, their old school, tomorrow). We were then entertained by Birgitta Svenden, opera singer from the Royal Theater of Stockholm. Vice President Bush spoke, expressing satisfaction with the now fine relations between U.S. and Sweden and recalling with pleasure the fine visit to 


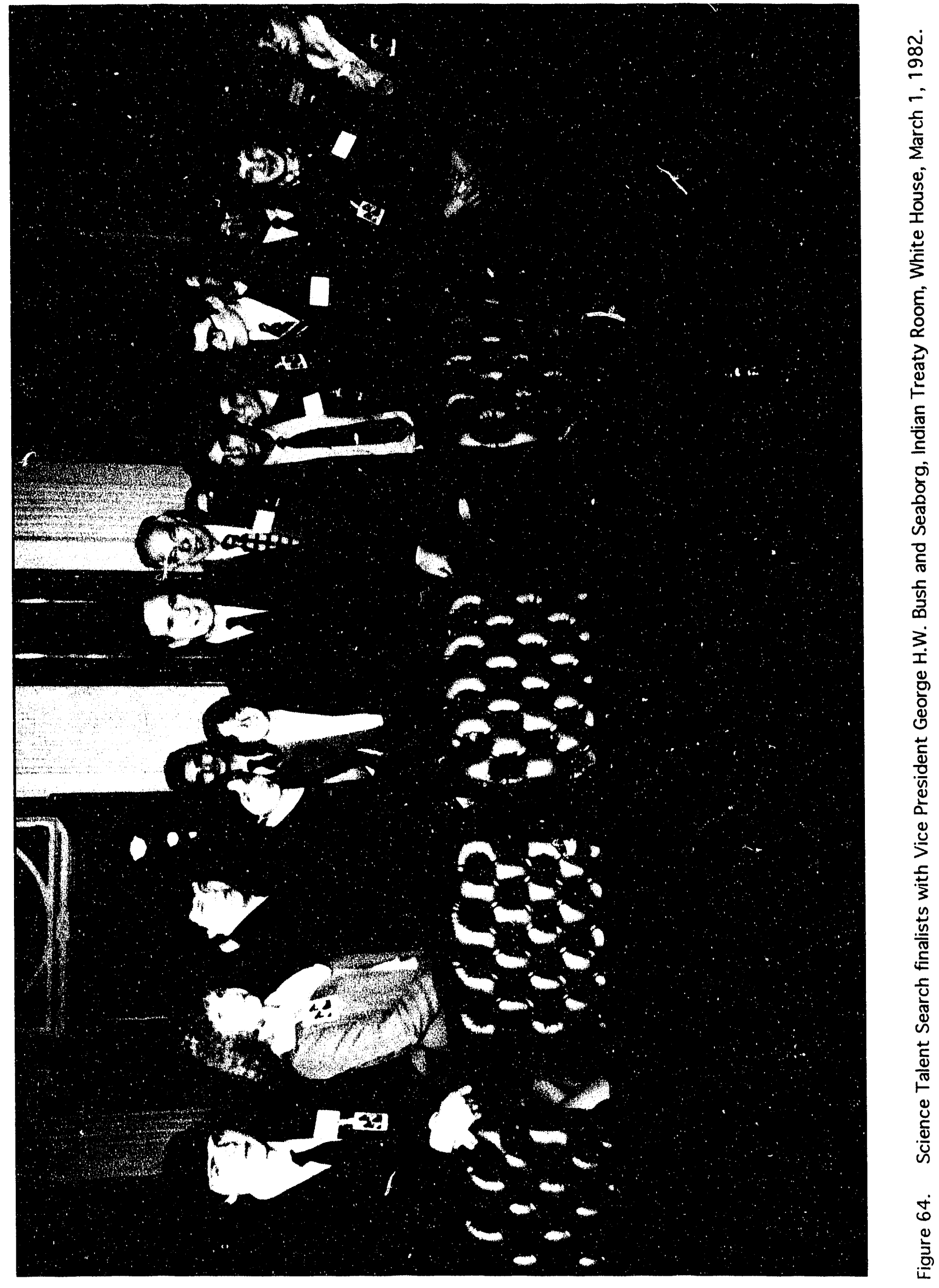




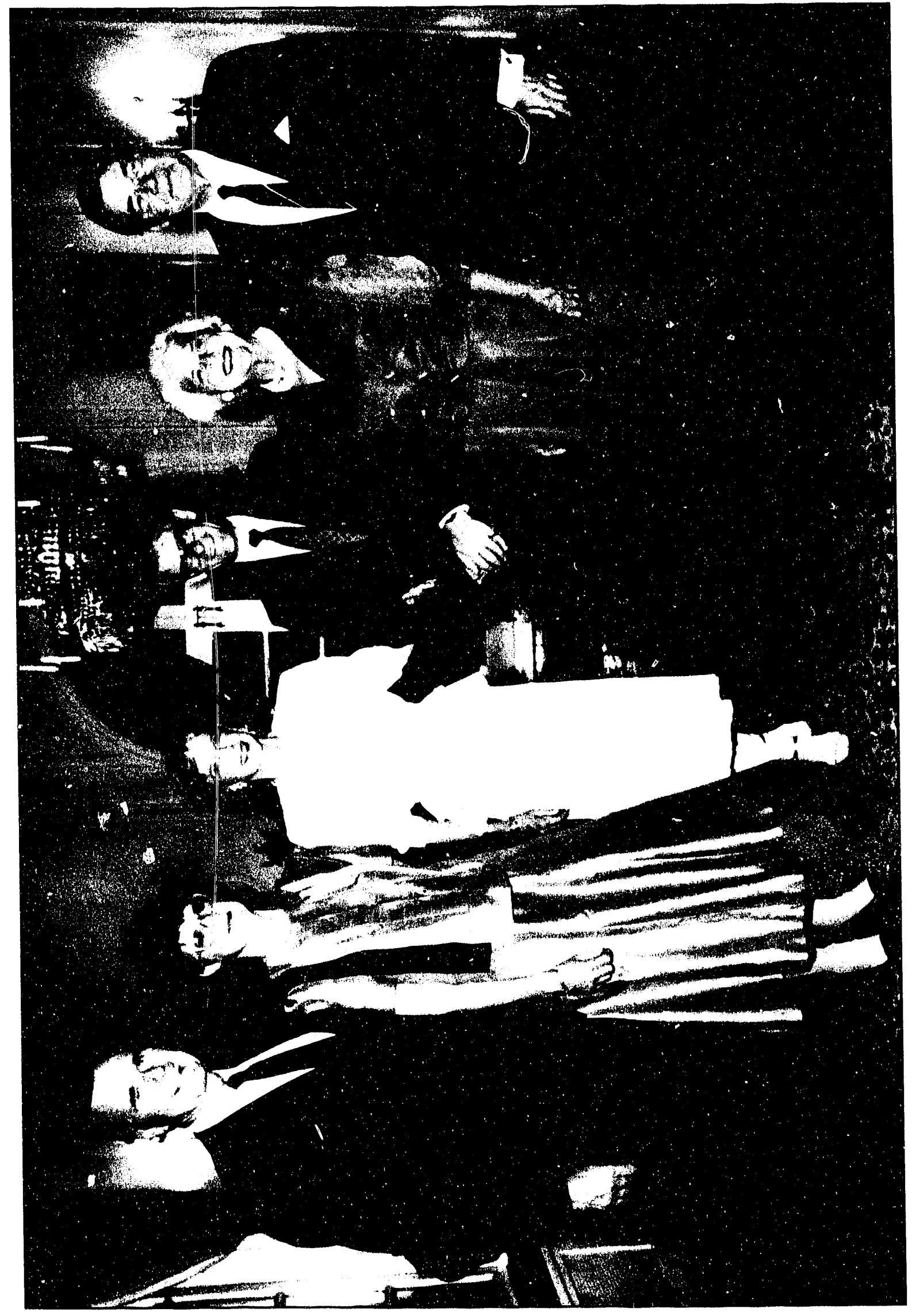

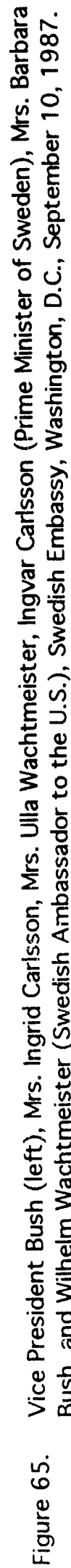


Sweden he and Barbara had in 1983. Ambassador Wachtmeister then brought the program to an end.

I talked further with Swedish Prime Minister Carlsson. He again told me about his productive meetings with the House and Senate Foreign Relations Committees today. I told him (as I learned today from Aaron Tovish) that the European Parliament has endorsed the amendment approach to a comprehensive test ban; this was news to him. I mentioned that the West German Social Democratic Party has also endorsed this approach; he knew about this. I also mentioned the favorable aititude of the central party in Denmark; he said the elections in Denmark were held just the other day. He said he will keep in touch with me and let me know about the conclusions that he and his advisors reach on the amendment approach...."

Early in his administration as President, Bush came to talk to the 40 finalists of the Westinghouse Science Talent Search at the National Academy of Sciences (Figure 66.) in Washington, D.C., on March 3, 1989:

$\quad$ "President
Bush arrived promptly
on schedule at 2:09
p.m. at the secondary
C Street entrance.
[John] Marous
[Chairman,
Westinghouse Electric
Corporation] and I,
followed by [Paul]
Lego [President,
Westinghouse Electric
Corporation] and
[Frank] Press
[President, National
Academy of Sciences]
and [Eileen] Massaro
[Director of Corporate
Relations,
Westinghouse Electric
Corporation], led
President Bush into
the Great Hall where
we conducted him on a
tour of a number of the
exhibits of the Science
Talent Search
finalists....He took
notes on several of the
exhibits including that
of Scott Schiamberg.
Marous described

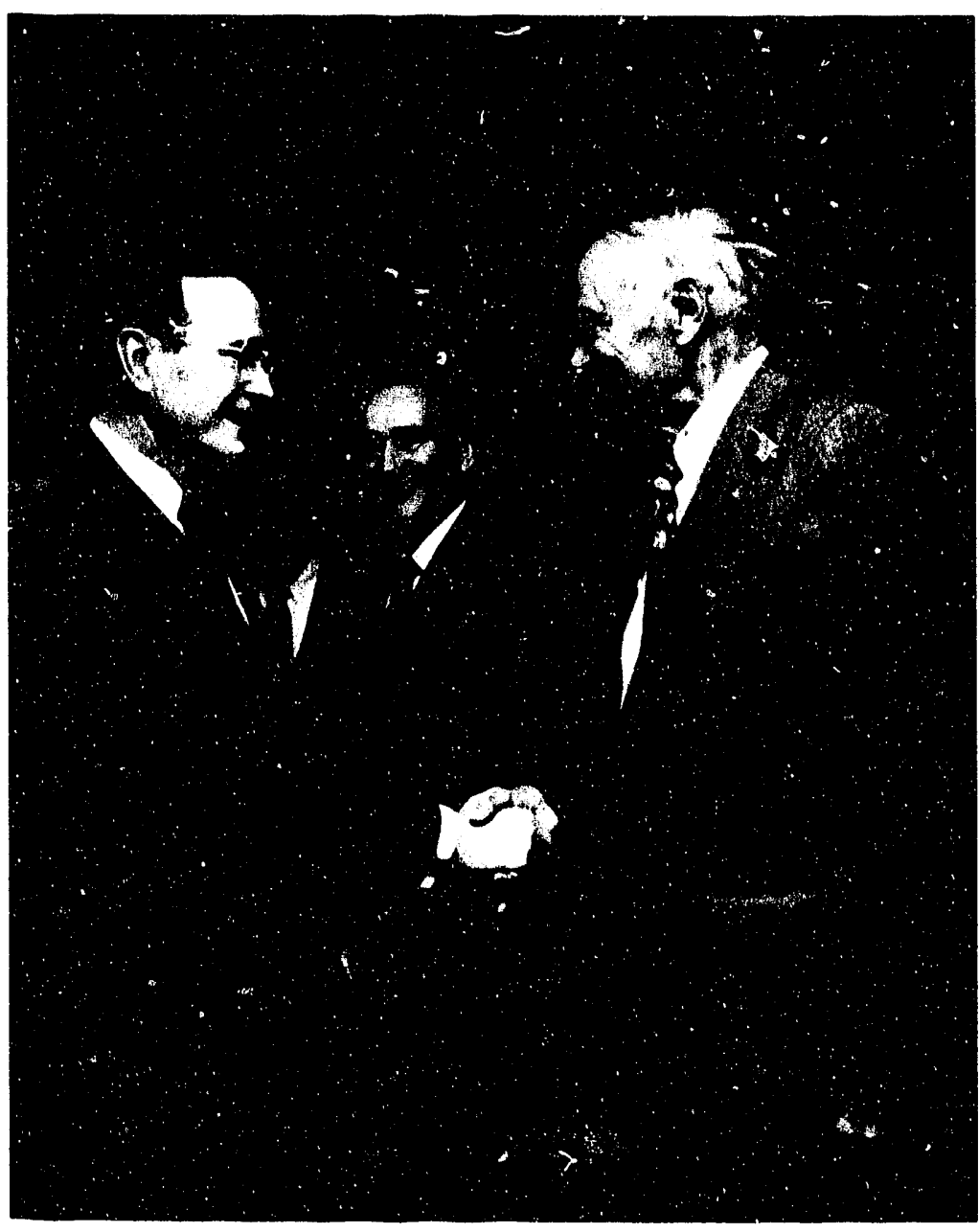

Figure 66. 48th Science Talent Search, National Academy of Sciences, Washington, D.C., March 3, 1989.

Left to right: Bush, Frank Press, Paul Lego (President, Westinghouse Corporation), and Seaborg. 
most of the exhibits and I added comments on a number of them including the one on "Chaos from Simplicity" by Michael Stern. I told him about the importance of chaos in recent years and tried to explain to him what this means. On one occasion I said (on the basis of a predetermination that I would do so) that the project was so complicated that I didn't understand it and that we would probably need the student to explain it to us.

Following our tour of the exhibits, we went into the auditorium where the 40 finalists were seated on the stage. The auditorium was nearly full with people who had been invited. Lego, Press, Marous, and I entered in that order and stood in our designated places on the stage. Then President Bush entered and stood in the center between Press and Marous. The program began with about two minutes of comments by Frank Press in which he made references to the National Arademy of Sciences, the STS finalists, and the importance of the work. (He didn't mention Science Service.) This was followed by about two rinutes of comments by Marous who mentioned the importance of the Westinghouse Science Talent Search, the role of Westinghouse, and so forth. (He didn't mention Science Service either.) Marous then introduced the President of the United States and President Bush spoke for about five to ten minutes using text typed on cards. He mentioned the importance of work on stopping the depletion of the ozone layer and he mentioned the plan to proceed with the construction of the Superconducting Super Collider. He began with references to the tour he had of the exhibits and, using notes he had made during the tour, made comments on several of the exhibits saying that he and his wife Barbara would discuss this at bedtime in order to pursue the matter further. At the end of his talk he was thanked by Marous. President Bush turned to the STS finalists and was told that Scott Schiamberg was the person who had prepared the exhibit on the "Preparation and Behavior of Inhibitors of Sialidases: Research on a Potential Cancer Therapy" to which he had referred. President Bush thereupon gave the first page of his speaking cards after he had signed it with "Good wishes, George Bush" to Scott Schiamberg.

As he was leaving President Bush shook hands with and spoke to each of the four of us standing on the stage. In my case he addressed me as "Glenn" and expressed pleasure at having the chance to see me and talk to me again. He then left and we greeted him again as he left through the $C$ Street entrance. He left at about 2:35 p.m. exactly on schedule."

The following month I was called back to Washington to brief George Bush on "cold fusion," the totally unexpected phenomenon that University of Utah scientists announced they had discovered. A couple of days earlier, the purported co-discoverer of "cold fusion," University of Utah electrochemist, Stanley Pons, spoke to an enthusiastic standing-room-only audience of chemists at the semi-annual meeting of the American Chemical Society in Dallas, Texas. His talk had attracted so much attention that, apparently, the news had reached the White House. After briefing White House Chief of Staff John Sununu, I went into the Oval Office to brief President George Bush on April 14, 1989: 
"DOE Secretary James Watkins, DOE Undersecretary John Tuck, DOE Director of Office of Energy Research Robert Hunter, and I then rode in a DDE car to the White House for an 11:15 a.m. appointment with John Sununu, White House Chief of Staff, and a number of his aides-Andy Card (Deputy to Sununu), Ed Rogers (one of Sununu's aides), and David Bates (secretary to President Bush's cabinet). We met for about 20 minutes in Sununu's office, during which I briefed him and his aides on the situation with respect to the cold fusion that has been announced by the University of Utah scientists. I said that there has been the observation in some places, including by Jones at Brigham Young University, of a low level of neutron emission, during the electrolysis of deuterium oxide--something at the level of one neutron per second--and the observation of about $10^{10}$ as much as heat by the University of Utah scientists led by Pons who have some rather exotic explanations in terms of aneutronic reactions. I indicated that there is a good deal of doubt about the validity of both of these observations. I said that there has been a tremendous reception in favor of this work at the annual meeting of the American Chemical Society in Dallas earlier this week, attended by about 7,000 chemists, including the President of the American Chemical Society Clayton Callis. I said that, on the other hand, a number of nuclear physicists take a very dim view of this development and, in effect, do not believe it. I indicated that my own view is one of some skepticism, but that I believe that it has to be investigated and that I have recommended the creation of a panel to look into it, and DOE Secretary Watkins indicated that the appointment of such a panel is underway. Sununu was very alert and seemed to understand what I was saying in view of his engineering background, and he asked me a number of penetrating questions which I believe that I was able to handle fairly well. Most of the conversation was between Sunuru and me.

I mentioned to Sununu that I was the codiscoverer of the radioactive iodine that was used a couple of days ago to treat Barbara Bush, which interested him very much. He said that he would see whether the president was available to see us and left us to go down the hall to check on this. He came back very soon and said that the president would be glad to see us, and we started off down the hall to the Oval Office to meet the president. We noticed that DOE Secretary Watkins wasn'. accompanying us (apparently he felt modestly that he shouldn't be included), but Sununu went back to get him....

We then went into the Oval Office, where President Bush greeted me cordially, addressing me again as "Glenn," and pictures were taken of Bush and me (Figure 67.), and of Bush, Watkins and me. We then all sat down to start our discussion, which lasted about 10 minutes. I told him about my role in the discovery of the radioactive iodine that had been used to treat Barbara and said that a similar treatment with radioactive iodine had effected a miraculous cure for my mother who was suffering from the same condition as Barbara. The president facetiously said that Barbara is now radioactive and she is not allowed to kiss their dog as long as this condition prevails, but he implied that it didn't seem that this prohibition included himself (the president). I then went on and described briefly the 
situation with respect to cold fusion. I indicated that this is something that has to be viewed dispassionately, that there are some indications that it is not a valid observation (that is, that it is not due to nuclear fusion) but, on the other hand, it must be looked into, and I mentioned the creation by the DOE of a panel that will look into this. The president seemed very interested and convinced by my assessment, and encouraged us very much to go aheat with an investigation of this intriguing situation. We also touched on the matter of the problem in precollege science and math education, and he indicated that this is something that also must receive his attention and that of the country."

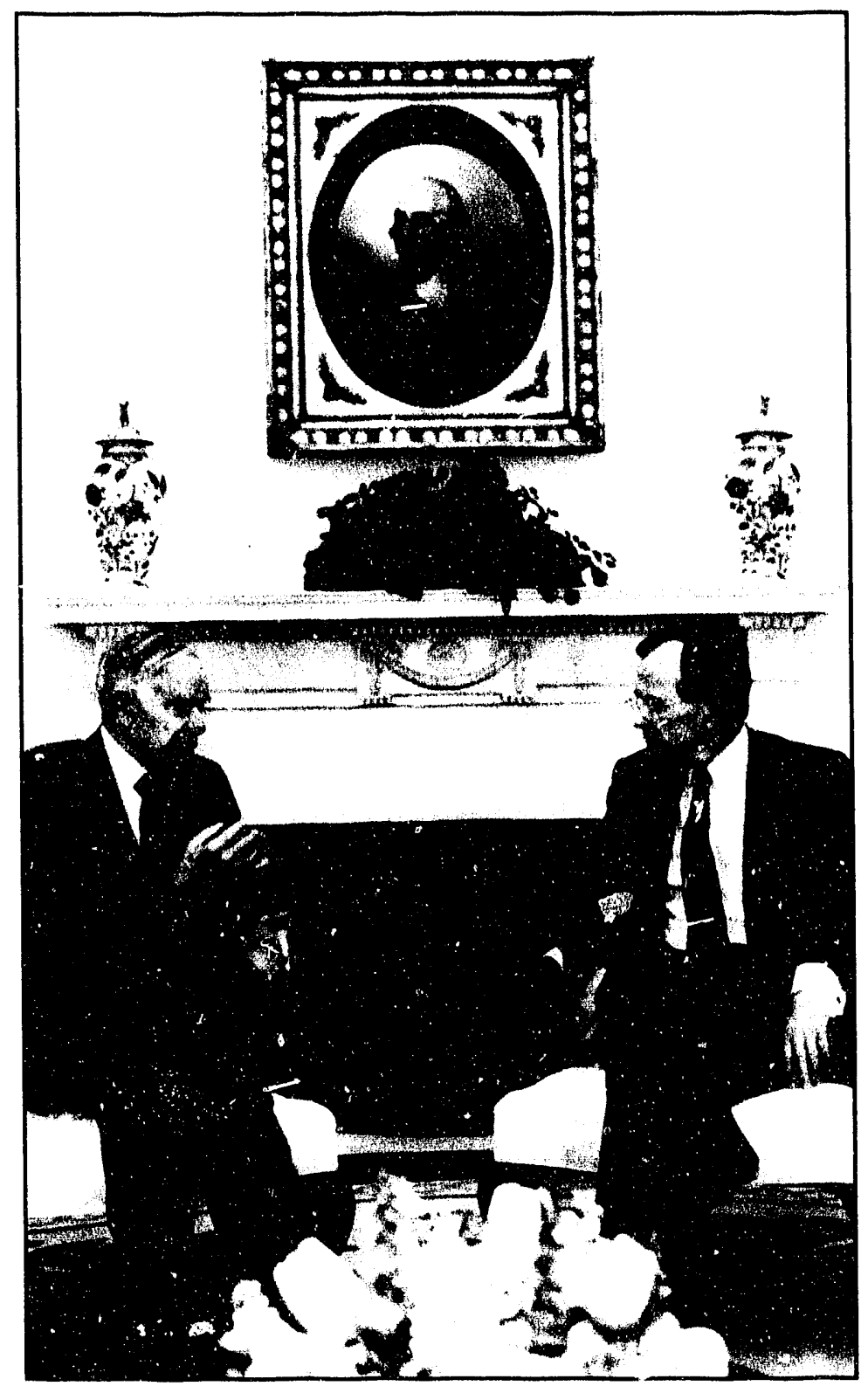

Figure 67. Seaborg briefing Bush on "cold fusion" phenomena, Oval Office, April 14, 1989.

I might add that the panel I recommended to study the purported "cold fusion" process was created and about six months later came out with a report disputing the validity of the observation, pretty much in line with the view I adopted in my briefing of the president. Also, it is interesting to note that Presicient Bush himself, two years later, in May, 1991, benefited from treatment with the same radioactive iodine (iodine-131).

I first met Vice President J. Danforth (Dan) Quayle, and his wife Marilyn, when I had the responsibility of helping to show them the exhibits of the student finalists of the Science Talent Search at the National Academy of Sciences on March 3, 1990: 
"I then went to the entrance into the back room area (where President Bush entered last year), and we formed a receiving line for the impending visit of Vice President Dan Quayle. The receiving line consisted of Paul Lego (incoming chairman, Westinghouse), Eileen Massaro (Vice President, Public Relations, Westinghouse), Ted Sherburne and Sam Thier (head, Research Institute of Medicine). Whon Vice President Quayle and his wife Marilyn arrived, individual pictures were taken as they passed [through] the receiving line, and then Paul Lego and I escorted them into the Great Hall to view the STS exhibits. We made a tour...Marilyn Quayle was particularly interested in Exhibit 24 which had to do with breast cancer; she was scheduled to participate in the making of a movie on this subject immediately following their visit to the Science Talent Search exhibition. During the tour pictures were taken by Westinghouse photographers (Figure 68.) and many other photographers. I tried to engage Vice President Quayle in conversation but without much success. I did, however, talk a good deal with Marilyn. I told her something about the Science Talent Search, the plans for a 50th anniversary celebration next year at which the 2,000 STS finalists will return, the div.rsity of the present participants (i.e., their coming from many parts of the country), and so forth.

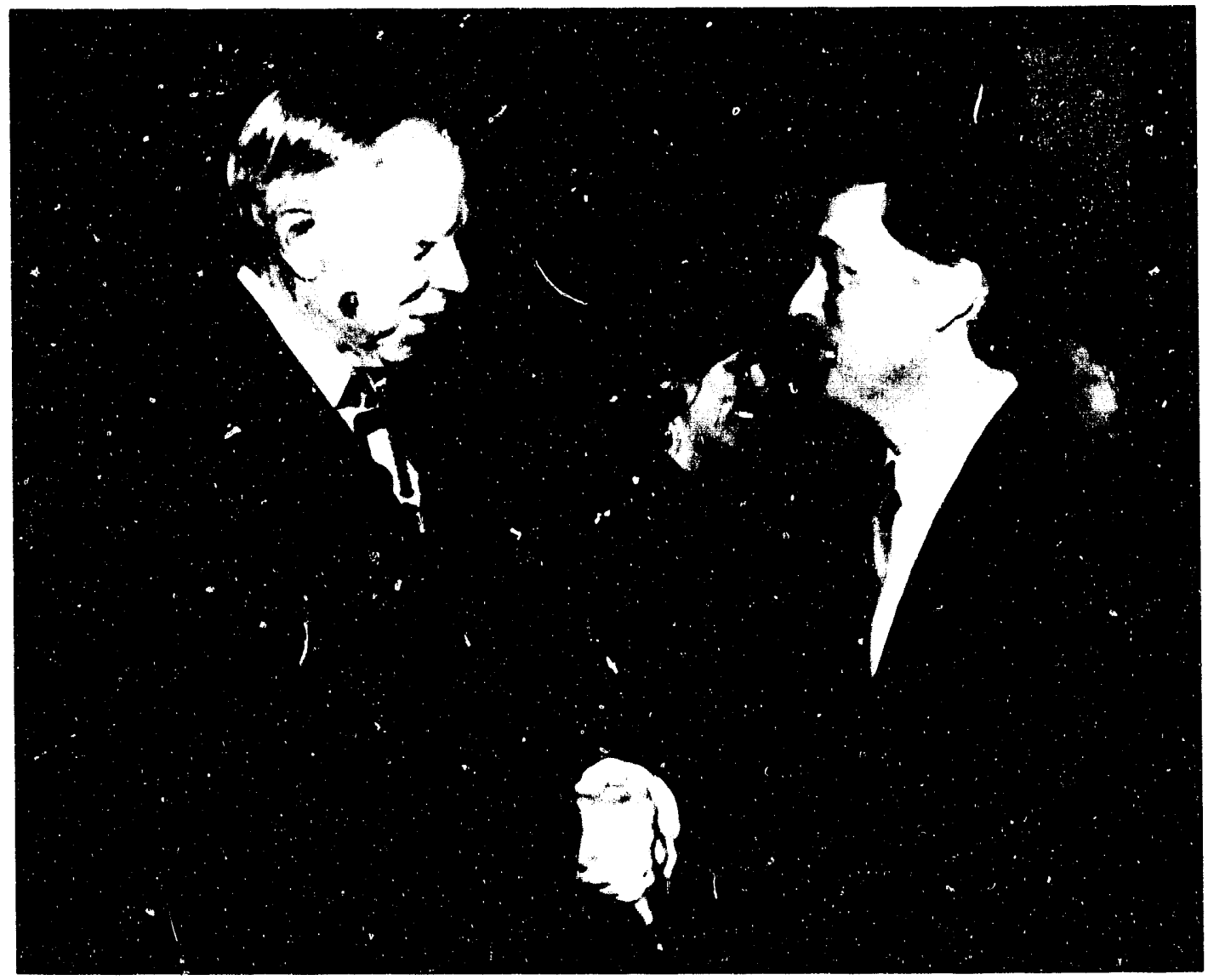

Figure 68. Seaborg with Vice President J. Danforth Quayle and M/arilyn Quayle at Science Talent Search. National Academy of Science. Washington, D.C., March 3, 1990. 
Following the tour Vice President Quayle walked up to a microphone on a little stage. Westinghouse Chairman-elect Lego was supposed to introduce him, but the confusion made this impossible. Vice President Quayle gave a short talk, describing from notes the exhibits that he had seen and extolling the virtues of the STS finalists. He and Mrs. Quayle then left through the same area of the building where they had entered."

I had the impression that his wife Marilyn had a much better understanding of the science exhibits than Vice President Quayle.

As early as his first State of the Union address in 1989, President Bush announced his National Education Goals (primarily for pre-college education). One result of this action was the president's famous Education Summit held in September, 1989 with the state governors in Charlottesville, Virginia. Then, on October 8-10, 1989, Department of Energy Secretary James D. Watkins and I served as co-chairmen of the Math/Science Education Action Conference at the Lawrence Hall of Science in Berkeley, California. The conference sponsors included the U.S. Department of Energy, the Lawrence Hall of Science, and the Lawrence Berkeley Laboratory, and nearly 250 scientists, educators, business executives, and government leaders attended. (Figure 69.) The objective was to

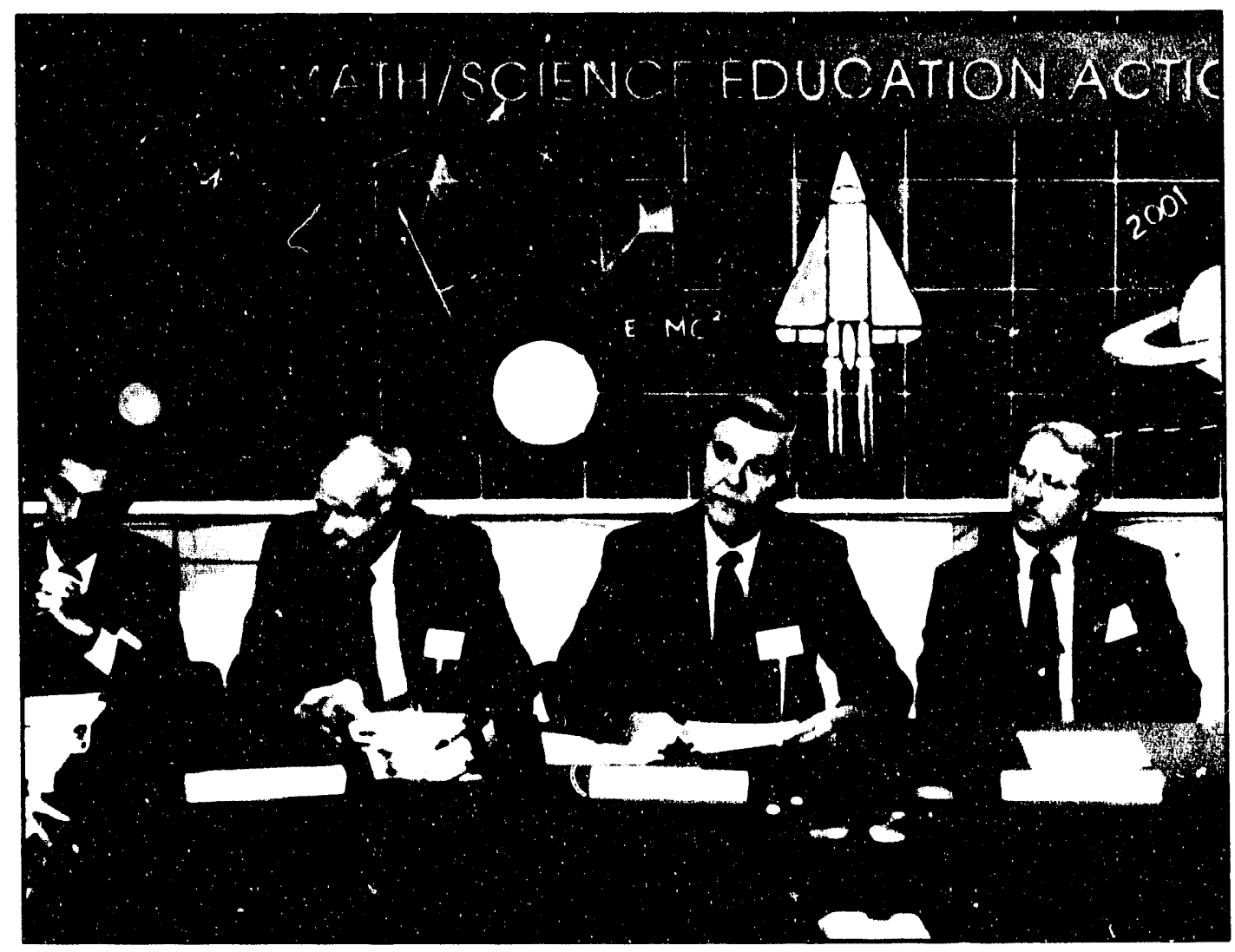

Figure 69. Seaborg (second from left), Secretary of Energy Admiral James Watkins, Vice Admiral Richard H. Truly (USN, Ret. and Administrator, National Aeronautics and Space Administration), and University of California President David P. Gardner at Math/Science Education Action Conference, Lawrence Hall of Science, University of California, Berkeley, CA, October 9, 1989. 
develop a concrete plan of action for restructuring and revitalizing pre-college mathematics and science education. Proposals, ideas and recommendations from the conference have resulted in many constructive actions, especially by the Department of Energy.

President Bush addressed the STS finalists and a large audience of returning STS finalists and their friends at the 50th Anniversary celebration of the Westinghouse Science Talent Search on March 4, 1991.

"At a little before 5 p.m. I went back to our room, where Helen and I donned our formal clothes for the evening's banquet. Helen and I then went down to attend the VIP reception in the Crystal Ballroom. At about 6 p.m. the STS finalists, Lego, Gott, Sherburne, Luczsz, Massaro, and other Westinghouse officials went to a special room to wait for the arrival of President Bush. Bush arrived at 7 p.m. and wert by a receiving line, consisting of Mr. and Mrs. Paul Lego, me, Ted Sherburne, and Richard Gott. (Figure 70.) After greeting a number of the STS finalists, he was brought by to visit and talk with the finalists standing by their exhibits-Judson Berkey (Thomas Jefferson High School for Science and Technology, Alexandria, Virginia), Susan Criss (Fox Chapel Area High School, Pittsburgh, Pennsylvania), Tara Bahna-James (La Guardia High School of Music and the Arts, New York, New York), and Yves Jeanty (Stuyvesant High School, New York, New York). The first visit was with the Berkey

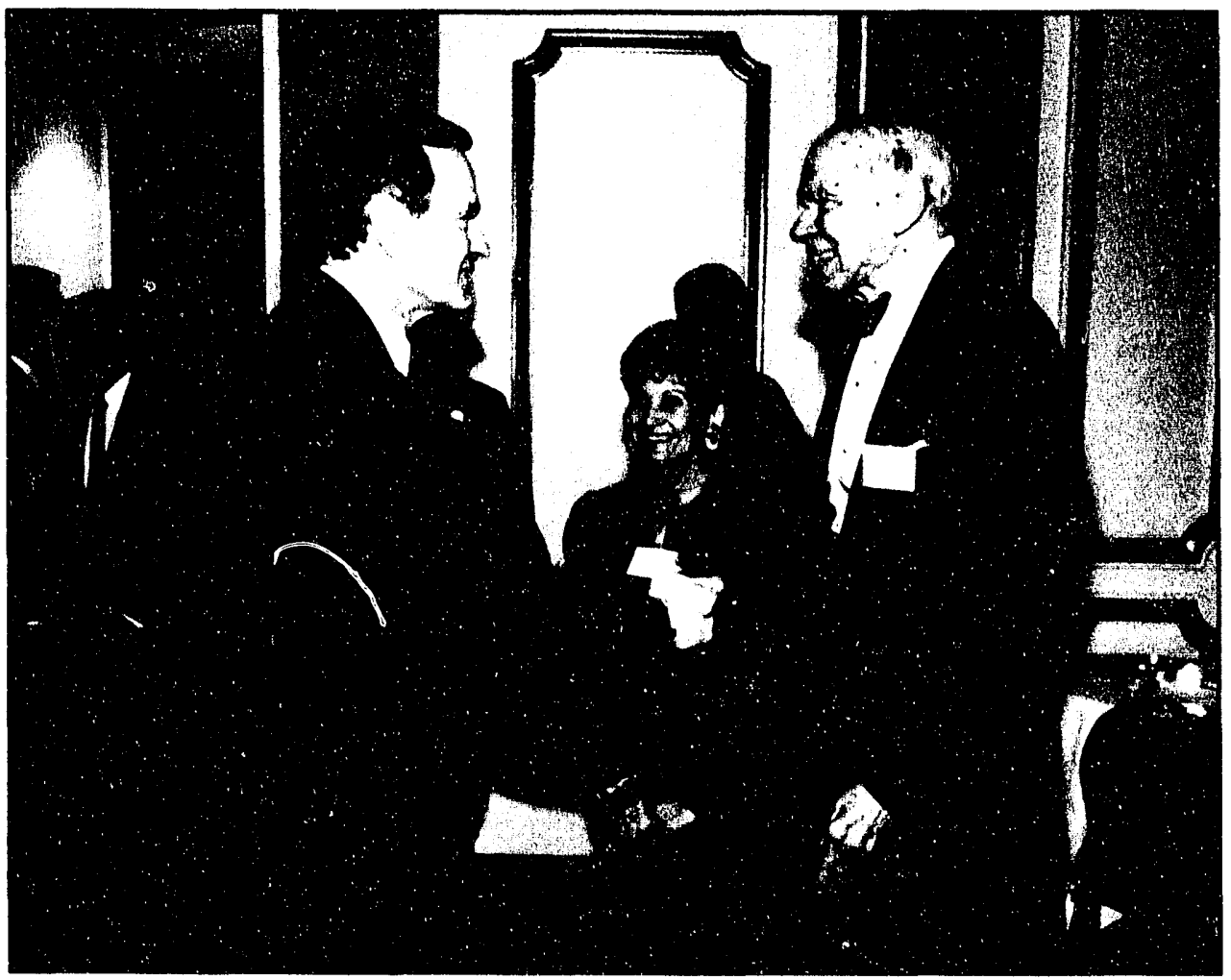

Figure 70. Bush and Seaborg at the 50th Anniversary of Science Talent Search, International Ballroom, Washington Hilton Hotel, Washington, D.C., April 4, 1991. 
exhibit, "The Optimal Launch Angle of a Baseball," and I took the occasion to comment to the president on his appearance in the college world series in 1947 as a member of the Yale team when our Berkeley team beat them for the collegiate championship. He said that unfortunately, he recalls this all too vividly! President Bush and his entourage left first and went to an area backstage in the International Ballroom. We all went to the International Ballroom, where the 40 finalists took places on the stage. Helen and I sat at a table with Mr. and Mrs. Paul Lego, Mr. and Mrs. Ted Sherburne, Richard Gott, and Barbara Franklin (Executive, Westinghouse Electric Corporation).

President Bush entered with Paul Lego to the playing of "Hail to the Chief" and was introduced by Paul Lego. President Bush included in his opening salutation a reference to me as "my old friend, Dr. Glenn Seaborg." His talk paid tribute to the contribution of the Westinghouse Science Talent Search to the identification of future scientists and engineers--so important in our society, and also made some reference to the success of our armed forces in the war in the Persian Gulf. He left to a standing ovation. Paul Lego then joined us at our table."

The last time I saw President George Bush was the occasion of his presentation to me of the National Medal of Science in a ceremony in the Rose Garden of the White House on September 16, 1991:

"Helen and I left our hotel about 9:30 a.m. and walked to the East entrance to the White House grounds where we joined (our son) Eric (Pete, our oldest son came a little later) and the recipients of the National Medal of Science and the National Medal of Technology, their guests, implementing staff of the National Science Foundation and the White House, and so forth. From here we went to the Rose Garden, where we talked to a number of the National Medal of Science recipients and their guests, including Elvin Kabat, Ronald Breslow, Guy Stever, Arthur Schawlow, Steven Weinberg and Robert Kates. The National Medal winners then went to their assigned seats and the others took seats in the designated area in the Rose Garden.

President George Bush entered at precisely 10:30 a.m. and introduced Robert A. Mosbacher (Secretary of Commerce), D. Allan Bromley (Assistant to the President for Science and Technology), Walter E. Massey (Director, National Science Foundation), and others. In his introductory remarks (about 10 minutes long), President Bush emphasized the importance of science and technology in today's society and singled out several of the Medal winners for special mention. He joked that as a result of his working to learn to operate computers during the last six months, he has cut down by a factor of five the time he takes to make mistakes.

Then Walter Massey read the citations as each recipient came up to receive the National Medal of Science from the president, who made a few remarks individually to the recipients; pictures were taken. Allan Bromley also shook recipients' hands. When I was with the president to receive the 
Medal of Science, he remarked that he was surprised that I hadn't received all the honors of this type years ago. (Figure 71.) I mentioned to him that he had met my son Eric in the Oval Office in June at the time of the hike across the United States and he professed to recall the occasion."

I believe my many contacts with George Bush, extending over more than twenty years during his service as U.N. ambassador, vice president, and president, have been amicable and pleasant.

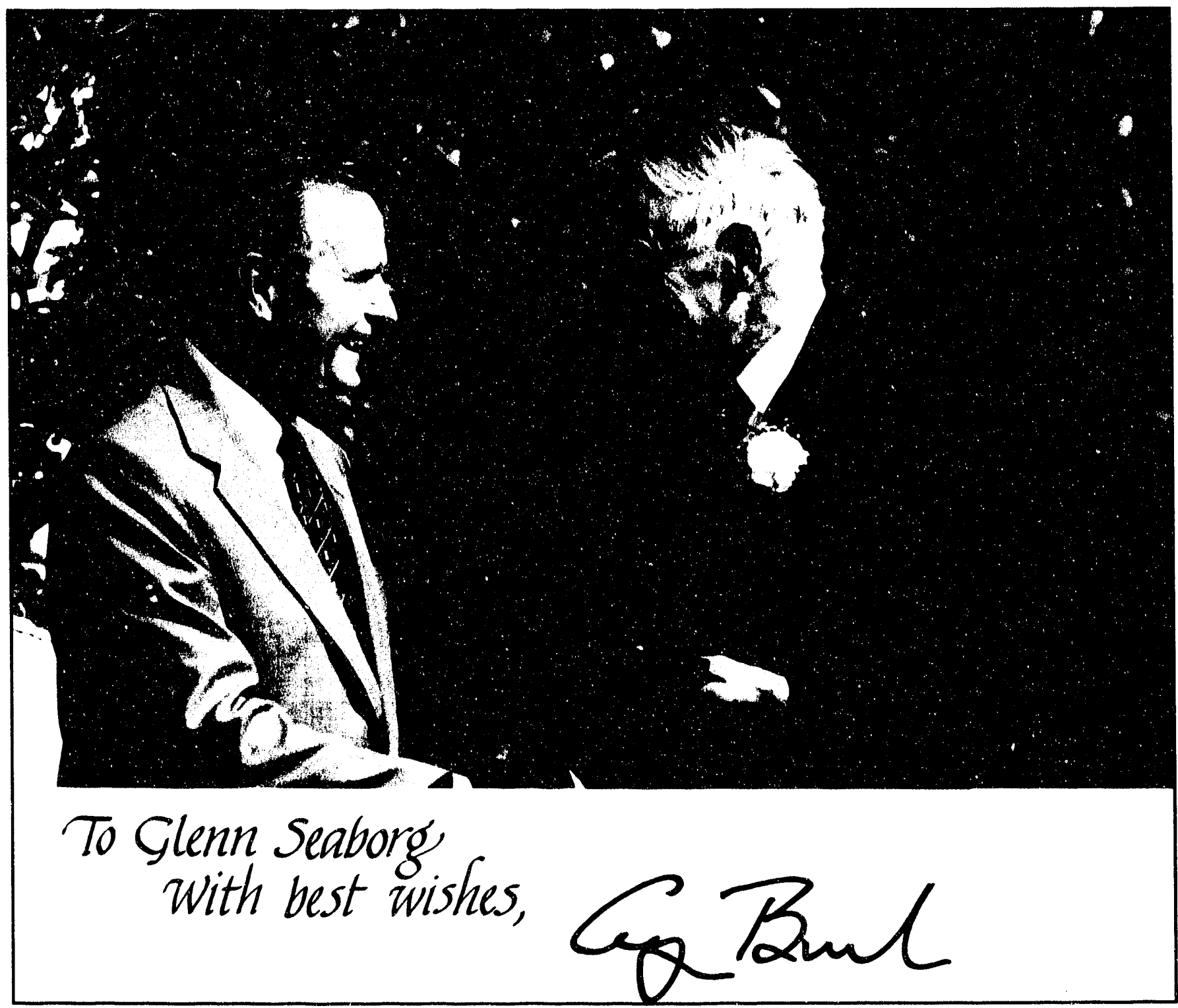

Figure 71. President of the United States George H.W. Bush presenting National Medal of Science to Professor Glenn T. Seaborg in ceremony at the White House Rose Garden, September 16, 1991. 


\section{Conclusion}

I have had the privilege of serving the last ten presidents of the United States--Franklin D. Roosevelt, Harry S Truman, Dwight D. Eisenhower, John F. Kennedy, Lyndon B. Johnson, Richard M. Nixon, Gerald R. Ford, Jimmy Carter, Ronald W. Reagan, and George H.W. Bush. An equal number (five) represents each political party; for the Democratic party--Roosevelt, Truman, Kennedy, Johnson, and Carter; for the Republican party--Eisenhower, Nixon, Ford, Reagan, and Bush.

I have also known the last twelve men who served as vice president-Henry A. Wallace, Harry S Truman, Alben W. Barkley, Richard M. Nixon, Lyndon B. Johnson, Hubert H. Humphrey, Spiro T. Agnew, Gerald R. Ford, Nelson A. Rockefeller, Walter F. Mondale, George H.W. Bush, and J. Danforth Quayle. Five of these men went on to serve as president.

I have also met all of these first ladies at times before, during, and/or after the presidential terms of their husbands--Eleanor Roosevelt, Bess Truman, Mamie Eisenhower, Jacqueline Kennedy, Lady Bird Johnson, Patricia Nixon, Betty Ford, Rosalynn Carter, Nancy Reagan, and Barbara Bush. Each of these first ladies brought a unique and inimitable charm to the White House, and Helen and I often recall many of the pleasant social occasions we enjoyed with the first ladies and their husbands.

I am pleased that my knowledge and experience as a scientist (and, perhaps, as an administrator) placed me in a position to provide national service to these presidents of the United States. But I am also pleased that I have also been able, through much of this period of time, to be an active researcher, teacher or university administrator.

I would like to conclude with some comments in a more personal vein. Sometimes I had to represent the Executive Branch of our government under trying circumstances when a show of humor helped. I am recently reminded of a story that occurred during my tenure as the Chairman of the Atomic Energy Commission. Cuts to the AEC's budget had forced the agency to begin laying off some machinists at the Oak Ridge complex in Tennessee. I was called by the Joint Committee on Atomic Energy to testify before the Congress to explain these cuts. I recall clearly committee member Senator Al Gore (D-Tennessee) asked me, "What do you have against machinists?" I responded by saying, "I don't have anything against machinists. In fact, my father was a machinist. My grandfather was a machinist. And my great-grandfather was a machinist." After a brief pause, I continued and said, "And if I had any talent for it, I would've been a machinist." At this remark, everyone, including Senator Gore, broke into laughter and the hearing essentially ended. 
I have found my opportunities for national service to be very interesting and instructive. The office of the President of the United States holds many pressures, and I feel privileged to have personally known so many of the men who have held that office, and to have observed and learned from the characteristics and values that each brought to his position. For various reasons, including among them the limited length of this manuscript, I have chosen not to make personal observations here comparing the effectiveness of each of these men as President of the United States. Such a comparison would require a careful evaluation of what qualities, experience, and actions under pressure best serve the people of the United States. I am considering the possibility of undertaking such a daunting task and expanding this manuscript into a book. My relations with each president were good, and in some cases, very close. Helen and I will not forget the merit and dedication of some of these men whose courage and conviction sustained them in the performance of their immense responsibilities. 


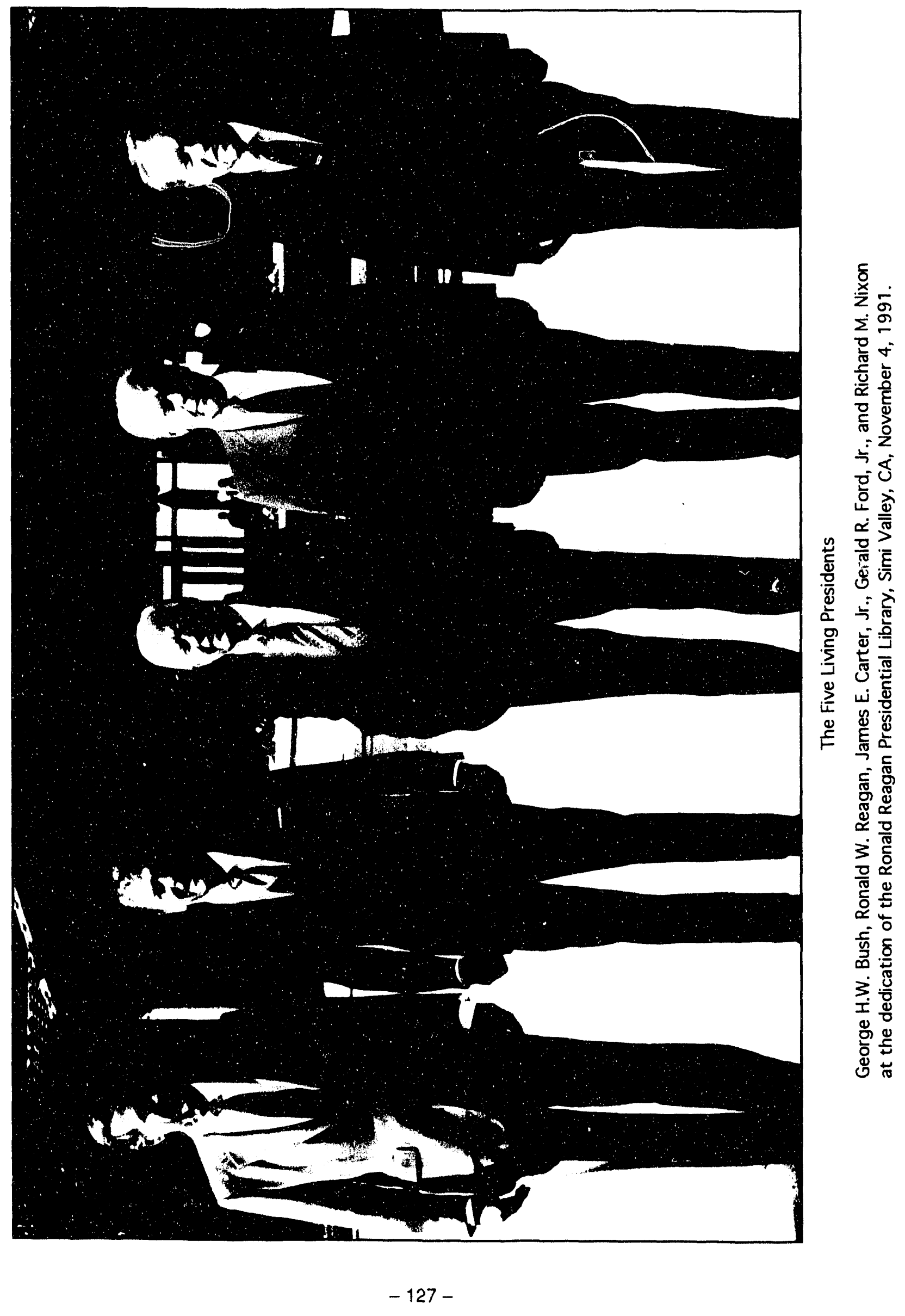




\section{PHOTO INDEX}

Page

Agnew, Spiro

Barkley, Alben W.

Bush, Barbara

Bush, George H.W.

Carter, James E., Jr.

Carter, Rosalynn

Eisenhower, Dwight D.

Eisenhower, Mamie

Ford, Betty

Ford, Gerald R., Jr.

Humphrey, Hubert $\mathrm{H}$.

Johnson, Lady Bird

Johnson, Lyndon B.

Kennedy, Jacqueline

Kennedy, John F.

Mondale, Walter F.

Nixon, Pat

Nixon, Richard M.

Quayle, J. Danforth

Reagan, Nancy

Reagan, Ronald W.

Rockefeller, Nelson

Roosevelt, Eleanor

Roosevelt, Franklin D.

Truman, Bess

Truman, Harry S

Wallace, Henry A.
85.

13.

115.

$114,115,116,119,122,124,127$.

$91,102,127$.

102.

17,19 .

17.

92.

$88,91,127$.

38,64 .

59,63 .

$14,43,44,45,50,52,53,54,56,59,63$.

32,41 .

$22,23,24,28,29,30,32,34,41$.

100.

63.

$63,66,69,71,73,79,91,127$.

120.

111.

$71,104,107,109,1.11,127$.

88.

9.

6,9 .

10.

$9,10,13,14$.

9. 


\section{PHOTO CREDITS}

Figure 1. Courtesy of the Franklin Delano Roosevelt Presidential Library, Hyde Park, New York.

Figure 2. Courtesy of the Franklin Delano Roosevelt Presidential Library, Hyde Park, New York. Copyright Abbey Rowe collection.

Figure 3. Courtesy of the Franklin Delano Roosevelt Presidential Library, Hyde Park, New York. Copyright by Haine Brothers, Brussels.

Figure 4. Courtesy of the Harry S Truman Presidential Library, Independence, Missouri.

Figure 5. Courtesy of the Harry S Truman Presidential Library, Independence, Missouri. Copyright by the Chicago Sun.

Figure 7. Courtesy of the Harry S Truman Presidential Library, Independence, Missouri.

Figure 8. Courtesy of the Lyndon Baines Johnson Presidential Library, Austin, Texas.

Figure 9. Courtesy of the Dwight David Eisenhower Presidential Library, Abilene, Kansas.

Figure 19. Courtesy of the John Fitzgerald Kennedy Presidential Library, Boston.

Figure 25. Courtesy of the Photographic Services Unit, Oak Ridge National Laboratory, Oak Ridge, Tennessee.

Figure 42. Courtesy of Shirley Burton-Cohelan.

Figure 51. Courtesy of the National Archives and Records Administration, Washington, D.C.

Figure 54. Courtesy of Joann DiGennaro, Center for Excellence (formerly Hyman G. Rickover Foundation), Washington, D.C.

Figure 55. Courtesy of the American Academy of Achievement, Malibu, California.

Figure 56. Courtesy of David Perlman, Science Editor, San Francisco Chronicle.

Figure 57. Courtesy of the American Academy of Achievement, Malibu, California.

Figure 58. Courtesy of the American Academy of Achievement, Malibu, California.

Figure 64. Courtesy of Science Talent Search, Washington, D.C. Copyright by Westinghouse photographic unit.

Figure 65. Courtesy of the National Archives and Records Administration, Washington, D.C. 
Figure 66. Courtesy of Science Talent Search, Washington, D.C. Copyright by Westinghouse photographic unit.

Figure 68. Courtesy of Science Talent Search, Washington, D.C. Copyright by Westinghouse photographic unit.

Figure 70. Courtesy of Science Talent Search, Washington, D.C. Copyright by Westinghouse photographic unit.

ENDSPIECE Courtesy of the Ronald Reagan Foundation, Los Angeles. 


\section{ACKNOWLEDGMENTS}

I wish to thank the people who assisted in assembling, researching photographs, and producing this report. Foremost among these was David Yan, who worked very closely with me over the course of several months in preparing this report. Caesar Cruz was of invaluable assistance in tracking down many of these photographs, and was assisted by a number of people at the various presidential libraries, the National Archives, the Library of Congress, the White House, and the morgues of various newspapers. Sherrill Whyte provided editorial and supervisory assistance. Finally, the Lawrence Berkeley Laboratory's Photography Department and Printing Plant did an excellent job of producing this report, which grew rapidly from a few pages to its present hefty, well-illustrated form. 
GLENN T. SEABORG is currently University Professor of Chemistry (the most distinguished title bestowed by the Regents), Associate Director of the Lawrence Berkeley Laboratory and Chairman of the Lawrence Hall of Science at the University of California, Berkeley.

He received his A.B. in Chemistry from UCLA in 1934 and his Ph.D. in Chemistry from Berkeley in 1937. He has served on the faculty of the Berkeley campus since 1939 and was Chancellor of that campus from 1958-1961. In 1961 Dr. Seaborg was appointed Chairman of the Atomic Energy Commission by President John F. Kennedy. He was subsequently reappointed by both Presidents Lyndon B. Johnson and Richard M. Nixon, serving in that position until 1971.

Winner of the 1951 Nobel Prize in Chemistry (with E. M. McMillan) for his work on the chemistry of the transuranium elements, Glenn Seaborg is one of the discoverers of plutonium (element 94). During World War II he headed the group at the University of Chicago's Metallurgical Laboratory which devised the chemical extraction processes used in the production of plutonium for the Manhattan Project. He and his coworkers have since discovered nine more transuranium elements: americium (element 95); curium (96); berkelium (97); californium (98); einsteinium (99); fermium (100); mendelevium (101); nobelium (102); and element 106. He holds over 40 patents, including those on elements americium and curium (making him the only person ever to hold a patent on a chemical element).

In 1944 Dr. Seaborg formulated the actinide concept of heavy element electronic structure which accurately predicted that the heaviest naturally occurring elements together with synthetic transuranium elements would form a transition series of actinide elements in a manner analogous to the rare earth series of lanthanide elements. This concept, one of the most significant changes in the periodic table since Mendeleev's 19th century design, shows how the transuranium elements fit into the periodic table and thus demonstrates their relationships to other elements.

His co-discoveries include many isotopes which have practical applications in research, medicine and industry (such as iodine-131, technetium-99m, cobalt-57, cobalt60 , iron-55, iron-59, zinc-65, cesium-137, manganese-54, antimony-124, californium-252, americium-241, plutonium-238), as well as the fissile isotopes plutonium-239 and uranium-233.

Dr. Seaborg continues to work as an active research scientist, with a research group in the search for new isotopes and new elements at the upper end of the periodic table, including a search for the "superheavy" elements. The group is also investigating the mechanism of the reactions of heavy ions with heavy element target nuclei. Another aspect of the research program is concerned with the determination of the chemical properties of the heaviest chemical elements.

Seaborg is the author of numerous books. His most recent, Elements Beyond Uranium (1990), is a comprehensive summary of all aspects of transuranium elements. Of particular interest to a lay audience are Kennedy, Khrushchev, and the Test Ban (1981) and Stemming the Tide: Arms Control in the Johnson Years (1987) which describe, respectively, the negotiations for the Limited Test Ban Treaty of 1963 and the Nonproliferation Treaty of 1969 . He has also authored over 500 scientific articles and guided the graduate studies of more than 65 successful Ph.D. carididates. In addition to the Nobel Prize and a grent many other awards for his work in chemistry, science education and community service, Dr. Seaborg has been awarded 50 honorary doctoral degrees. 
Among his many interests are international cooperation in science, history of science (documenting the early history of nuclear science), nuclear arms control (advocating a comprehensive test ban treaty), and hiking. A member of the National Commission on Excellence in Education which published the much-puolicized report A Nation At Risk in 1983 and Chairman of the Lawrence Hall of Science, Dr. Seaborg is recognized as a national spokesman on education, addressing in particular the crisis in mathematics and science education. 
The Lniversity of Californis, in compliance with Titles 11 and $V 11$ of the (ivil Rights Act of

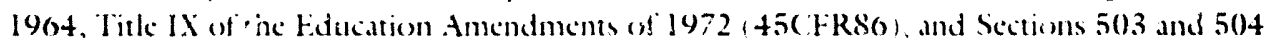
of the Reinabilitation Aet of 1973 , dexes not discriminate on the basis of race, color, national origin, religion, sex, or handicap in any of its policies, precedures, or practices, not does the Lnicersity, in compliance with the Age Discrimination in Fimployment Acs of 1967 and Section \$02 of the Victnam Era Veterans Reddjustment Act of 1974, discriminate against any employec: or person secking :mplowment on the hasis of their age or because they are disabled veteram of the lictmam era.

In combormance with the Liniversity policy and pursumt to kiccutive ()rder 11240 as amended

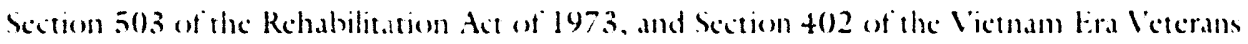

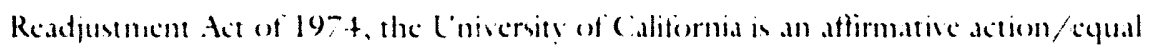
opportunity emploser.

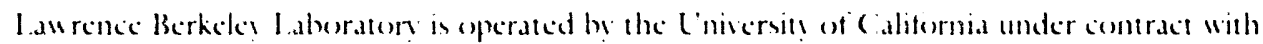
the L's. I)epartment of fencrgs.

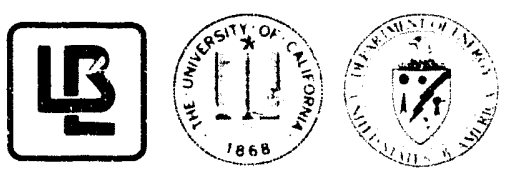

PUB-704 

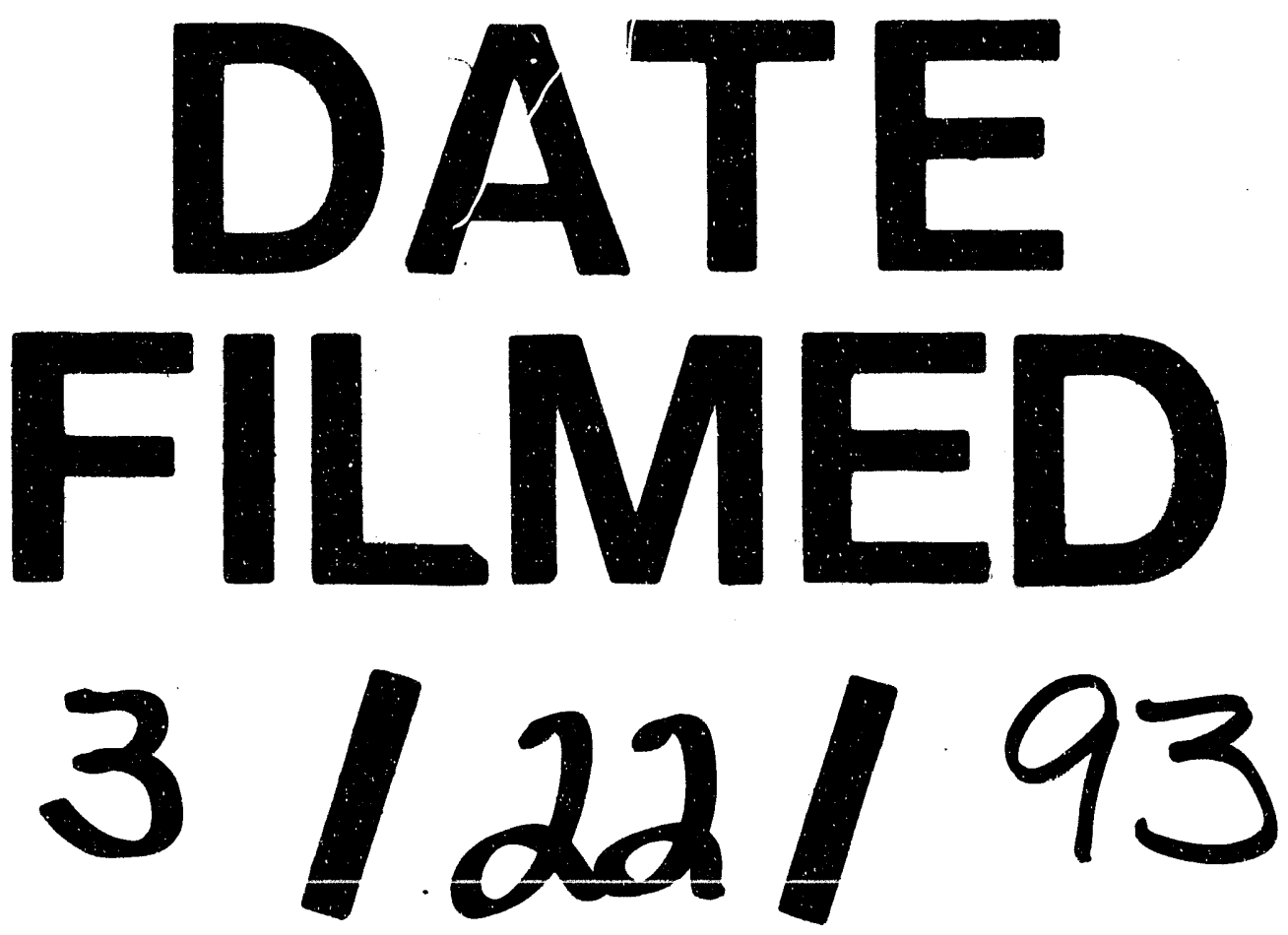
